\author{
UNIVERSIDADE DE SÃO PAULO \\ INSTITUTO DE ESTUDOS BRASILEIROS \\ PROGRAMA DE PÓS-GRADUAÇÃO \\ CULTURAS E IDENTIDADES BRASILEIRAS
}

LUÍS EDUARDO LOPES GONÇALVES

A metamorfose na obra de Murilo Rubião: mecanismos, símbolos e particularidades

(Versão corrigida)

São Paulo

2018 


\author{
UNIVERSIDADE DE SÃO PAULO \\ INSTITUTO DE ESTUDOS BRASILEIROS \\ PROGRAMA DE PÓS-GRADUAÇÃO \\ CULTURAS E IDENTIDADES BRASILEIRAS
}

\title{
A metamorfose na obra de Murilo Rubião: mecanismos, símbolos e particularidades
}

\section{LUÍS EDUARDO LOPES GONÇALVES}

Dissertação apresentada ao Programa de Pós-Graduação Culturas e Identidades Brasileiras do Instituto de Estudos Brasileiros da Universidade de São Paulo, para a obtenção do título de Mestre em Literatura Brasileira.

Área de concentração: Estudos Brasileiros

Orientador: Prof. Dr. Fernando Augusto Magalhães Paixão

(Versão corrigida)

São Paulo

2018 


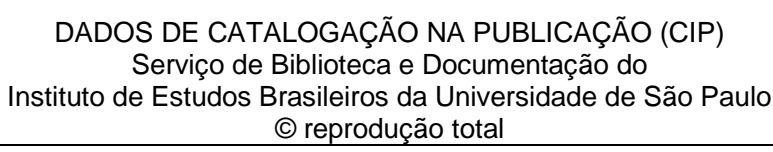

Gonçalves, Luís Eduardo Lopes

A metamorfose na obra de Murilo Rubião : mecanismos, símbolos e particularidades / Luís Eduardo Lopes Gonçalves -- São Paulo, 2018.

Orientador : Prof. Dr. Fernando Augusto Magalhães Paixão.

Dissertação (Mestrado) - Universidade de São Paulo. Instituto de Estudos Brasileiros. Programa de Pós-Graduação em Culturas e Identidades Brasileiras. Área de concentração: Estudos Brasileiros. Linha de pesquisa: Brasil: a realidade da criação, a criação da realidade.

Versão do título para o inglês: The metamorphosis in the work of Murilo Rubião : mechanisms, symbols, and particularities.

Descritores: 1. Rubião, Murilo, 1916-1991 2. Literatura brasileira 3. Literatura fantástica 4. Prosa 5. Conto 6. Narrativa I. Universidade de São Paulo. Instituto de Estudos Brasileiros. Programa de Pós-Graduação II. Título. 
Os deuses passam o passado e o presente a reconstruir fragmentos do futuro.

Murilo Mendes 


\section{Agradecimentos}

Aos meus pais, que nunca duvidaram.

Às minhas irmãs, que estão sempre ao meu lado, de mãos dadas e firmes.

Ao Pedro, pelo equilíbrio, pelos inúmeros debates, pela inteligência das críticas, pela paciência e por ter me guiado até o fim.

Ao Fernando, pela leitura sempre certeira e pela confiança sempre animadora.

A todos os meus amigos, pela alegria imprescindível.

A todos os funcionários e colegas do IEB, pela gentileza e pela solidariedade. 


\section{Resumo}

Este estudo propõe-se a analisar aspectos da obra do escritor mineiro Murilo Rubião (1916 1991), composta de 33 contos e de alguns textos esparsos. Após uma revisão bibliográfica da crítica sobre a trajetória de sua produção, pretende-se aprofundar e dar novas perspectivas à investigação da ocorrência da metamorfose, figura presente em quase todas as suas narrativas e essencial para entender a particularidade da "literatura fantástica", tal como aparece no trabalho do escritor. Como a metamorfose é recorrente nesse gênero e em suas variantes, este trabalho buscará mostrar suas singularidades na literatura de Murilo Rubião e rastrear as características que a definem. Além disso, também será feito um exercício comparativo entre a obra do escritor brasileiro e de outros escritores. Por fim, ao longo de todo o estudo, será analisada a discrepância que existe entre as duas linhas de força mais marcantes da metamorfose nos contos de Rubião - sua potência simbolizadora e sua tendência ao mero artifício.

Palavras-chave: Murilo Rubião; Literatura brasileira; Literatura fantástica; Prosa; Conto; Narrativa. 


\begin{abstract}
The present material aims to analyze some aspects about the work of the writer Murilo Rubião (Minas Gerais, 1916 - 1991), which is comprised by 33 short stories and some scattered pieces. After providing a bibliographic review of the critics on the trajectory of his production, it is intended to deepen and to give new perspectives on investigating the occurrence of metamorphosis, a frequent feature in almost all his narratives and essential to understand the particularity of the "fantastic literature", such as it appears in his creations. Since the metamorphosis is recurrent in that genre and its variants, this study seeks to exhibit its singularities in Murilo Rubião's writing and to track its defining characteristics. Furthermore, a comparative exercise is to be done between the most remarkable power lines of the metamorphosis in Rubião's works - its symbolizing strength and its tendency to be mere artifice.
\end{abstract}

Key-words: Murilo Rubião; Brazilian literature; Fantastic; Prose; Short story; Narrative. 


\section{Sumário}

Introdução. 10

Capítulo I - O impasse angustiado da escrita e o caminho singular de Murilo Rubião. .14

1.1. Repercussão da obra e percalços da crítica...................................................................15

1.2. Obra de muitos espaços (parte I): Murilo Rubião e o fantástico tradicional.......................25

1.3. Obra de muitos espaços (parte II): Murilo Rubião urbano..................................................30

1.4. Obra de muitos espaços (parte III): Murilo Rubião e o realismo maravilhoso.....................36

1.5. A angústia da criação e os labirintos da reescrita............................................................43

Capítulo II - O palco das metamorfoses: entre mecanismos artificiais e máscaras grotescas...50

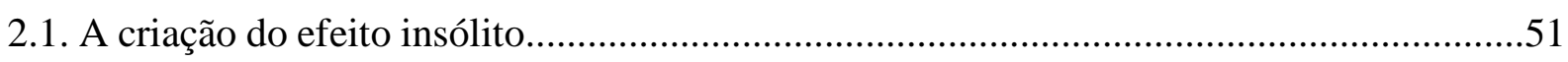

2.2. Comparações: as metamorfoses de Kafka e de Lautréamont..............................................55

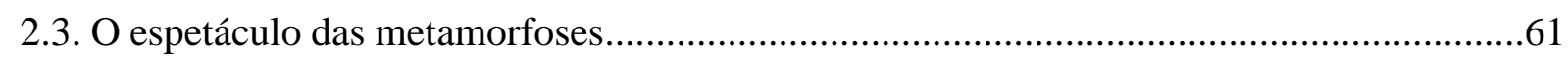

2.4. A metamorfose técnica: o assombro grotescamente hiperbólico......................................68

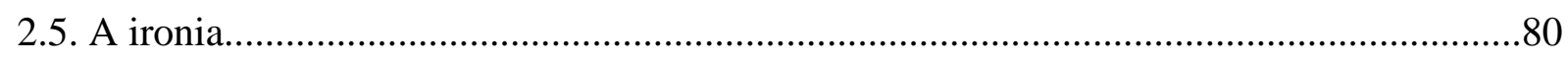

Capítulo III - Fronteiras e atalhos entre o homem e o animal: a metamorfose em Teleco, o

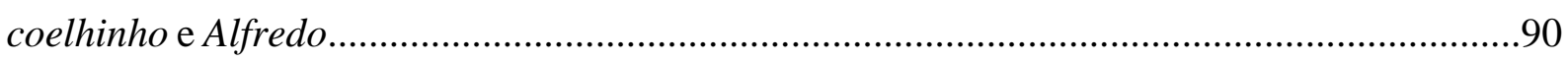

3.1. As metamorfoses de Teleco: os animais na ficção de Murilo Rubião................................91

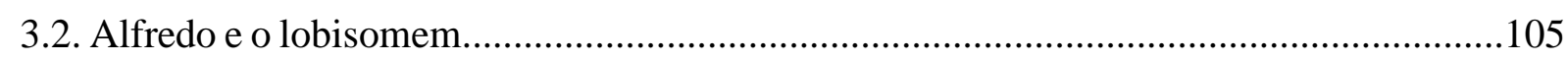

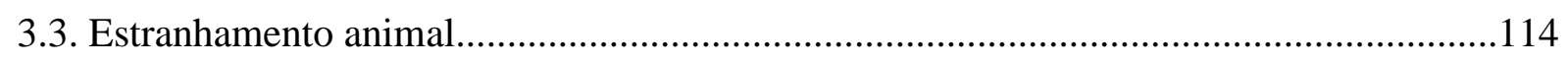

Capítulo IV - Conclusão - A exigência metamórfica.........................................................123

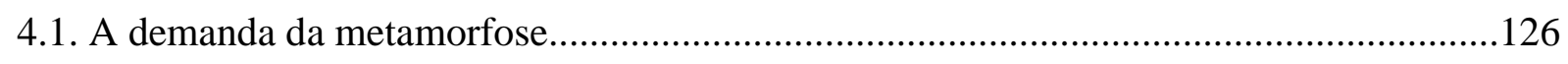

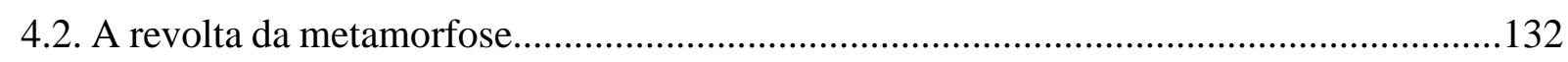

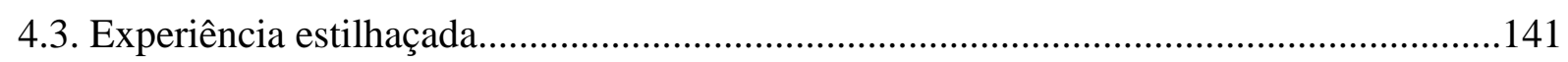

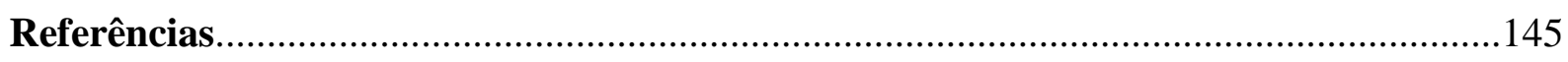




\section{Introdução}

A maior dificuldade na abordagem de um tema como a metamorfose na literatura é ter de deixar de lado, para a economia do estudo, uma história cujo início antecede a própria escrita. Sua ancestralidade, não nos parece demasiado afirmar, remonta ao primeiro olhar deslumbrado diante do mundo. Muito antes da ciência, de Darwin e do evolucionismo, todos os povos observaram e puderam intuir a semelhança e a continuidade que existe entre os elementos da natureza. Para chegar a isso, bastava a contemplação. Para essa contemplação, por sua vez, desembocar em lendas e mitos sobre a origem da Terra e de todos os seus habitantes, bastava a sua conversão em fala e, posteriormente, em escrita. Assim, o homem começou a crer na onipotência de suas próprias palavras, de seus pensamentos e, além de observar o universo em constante mutação, passou a esconjurar novas metamorfoses em mitos, fábulas e contos de fada. Antes de tudo, essas histórias expressavam a comunhão existente entre seus personagens, o tempo e o espaço que os cercavam. Invocavam forças espirituais cuja realidade não se distinguia em nada da materialidade das pedras, das plantas e dos animais. Tudo estava passível de ser metamorfoseado e possuía ascendentes muito diferentes da figura ora apresentada.

Entre os gregos antigos, por exemplo, a metamorfose estava intimamente ligada à cosmogonia que explicava a formação do mundo e da mitologia desse povo. Por conseguinte, o tema da metamorfose influenciava a própria criação da literatura clássica. Com efeito, uma das modalidades favoritas da épica grega era a de tema cosmogônico, ou seja, aquela que lançava mão de uma infinidade de metamorfoses entrelaçadas para explicar e fundamentar o nascimento dos deuses, das coisas e dos homens, como na Teogonia e n'Os trabalhos e os dias de Hesíodo. Embora ela tenha sido eclipsada pela epopeia dos grandes heróis - o que não significa que esta estava imune às metamorfoses, pelo contrário, basta lembrarmos dos terríveis porcos de Circe -, o relato épico sobre as origens do mundo exerceu forte influência sobre o imaginário ocidental ${ }^{1}$.

\footnotetext{
${ }^{1}$ João Angelo Oliva Neto explica historicamente a épica cosmogônica - ou seja, os textos de Hesíodo e de Ovídio -, da seguinte maneira: “A modalidade cosmogônica, ainda praticada por Ovídio no século I d.C., embora menos conhecida do que a heroica [...], também é originariamente arcaica, pouco mais recente, porém, do que os poemas homéricos, compostos no século VIII a.C. Hesíodo (ativo entre 750 e 650 a.C.), tal como Homero, foi poeta do Período Arcaico grego, autor de duas breves cosmogonias [...]. A Teogonia e Os trabalhos e os dias são os mais antigos exemplos de cosmogonia no Ocidente e perfazem o modelo primeiro que Ovídio teve em mente (entendase 'imitou') ao compor as Metamorfoses [...]”. Ver em: NETO, João Angelo Oliva. Mínima gramática das Metamorfoses de Ovídio. In: OVÍDIO. Metamorfoses. Trad. DIAS, Domingos Lucas. São Paulo: Editora 34, 2017, pg. 8 .
} 
Curiosamente, quem levou esse gênero à sua máxima expressão não foi um grego, mas o poeta romano Ovídio em suas Metamorfoses. Divididas em 15 livros, elas tecem e ligam grande parte dos mitos da tradição greco-romana sobre a origem do mundo, assim como certas histórias vindas do Oriente, a fim de criar uma trama que une desde o primeiro sopro de vida no Universo até o Império Romano sob o domínio de Augusto. A esse entrelaçamento dos acontecimentos mitológicos e históricos corresponde, igualmente, um entrelaçamento das formas. Nas Metamorfoses, os personagens que se transformam em árvores, em animais ou em rios já carregam consigo, de antemão, as características da sua nova imagem. No mito de Dafne e Apolo, a ninfa já possuía cabelos que lembravam a copa do loureiro e seus membros se assemelhavam com perfeição à delicadeza de seu tronco.

Além disso, Ovídio faz uso de técnicas formais que entrelaçam seus versos e reforçam o caráter aglutinador da sua épica dos movimentos do mundo. Assim, ele salienta a contiguidade entre os diferentes acontecimentos narrados e os elementos descritos. Segundo Italo Calvino, o poeta latino, inspirado pela literatura vinda do Oriente - especialmente pelo romance alexandrino -, consegue articular nos livros de suas Metamorfoses a técnica de "multiplicação do espaço interior à obra", cujos "relatos encadeados uns nos outros" fazem "aumentar a impressão de densidade, de aglomeração, de enredamento"2. Por meio dessa artimanha de dar origem a cenas que, por sua vez, são retratos de outras cenas e estão sempre encadeadas com a totalidade da obra (algo bastante semelhante à estrutura das histórias narradas por Sherazade n'As mil e uma noites), a intensidade das metamorfoses aumenta e garante imagens vívidas desse universo que não para de se transformar.

Por fim, esses ciclos metamórficos ecoam outros textos e se justificam a partir deles, realizando um exercício metalinguístico que expande os próprios limites das Metamorfoses. Há, por exemplo, a presença nítida de passagens da Ilíada e da Odisséia e de fragmentos teóricos de Pitágoras em sua obra - no último livro, o poeta fundamenta filosoficamente seu trabalho a partir das doutrinas do pensador grego. Dessa forma, Ovídio não busca legitimidade para seus versos apenas no conjunto mitológico compartilhado entre os cidadãos romanos, mas também na tradição científica herdada da Grécia e continuada por Roma. Ao articular mitologia, história e filosofia nas Metamorfoses, Ovídio logra dar voz à totalidade de uma cultura.

Além do tema em comum, contudo, em que mais nos interessa esse pequeno preâmbulo sobre um texto que, devido à sua grandiosidade e à sua inegável importância, parece exigir palavras igualmente grandiloquentes? Qual a relação que se pode estabelecer entre Ovídio, cuja

\footnotetext{
${ }^{2}$ CALVINO, Italo. Ovídio e a contiguidade universal. In: Por que ler os clássicos. Trad. MOULIN, Nilson. São Paulo: Companhia das Letras, 2007, pg. 36.
} 
produção literária data do início da era cristã, e Murilo Rubião, um escritor de contos curtos do século XX? Por acaso, a resposta surge da própria discrepância entre os dois. No caso do poeta latino, as metamorfoses se oferecem como fios entre os eventos do mundo e como nós que os atam numa só rede, tal qual as tramas da personagem mitológica Aracne - tecelã cuja transformação em aranha é narrada no livro VI e que metaforiza o próprio trabalho de Ovídio. Já no caso dos contos de Rubião, como veremos com mais detalhes nas próximas páginas deste estudo, as metamorfoses parecem esbarrar em empecilhos que confinam sua potência e que mantêm sob suspeita seus propósitos.

Em vez de nascerem da exigência por uma contiguidade entre as matérias, as metamorfoses da prosa muriliana parecem guiadas por uma lei contrária à ordem do mundo. Não que elas sobressaltem os personagens e o leitor com seus resultados insólitos, pois seus movimentos ostensivos sempre ganham a naturalidade de eventos ordinários conforme a narrativa avança. No entanto, elas rompem com a razoabilidade da vida comum. Os agentes das metamorfoses - muitas vezes transformados em vítimas - são empurrados para espaços marginais. Longe de representarem a totalidade do mundo, tais mutações marcam uma ruptura do ser metamorfoseado com o restante dos homens.

Da potência das metamorfoses de Ovídio, resta apenas o eixo quantitativo. Na obra de Murilo Rubião, elas também são numerosas e profícuas em imagens aberrantes, porém desaparece aquela continuidade entre a primeira forma e a segunda forma de um mesmo ser. Resta tão-somente o impulso hiperbólico por transformação, que faz uma mesma criatura se metamorfosear numa infinidade de animais aleatórios, sem jamais alcançar sua fantasia ideal. Já não há mais a presença de uma teia capaz de conectar com firmeza todas as suas extremidades. Pelo contrário, as metamorfoses em Rubião se assemelham a fragmentos de experiência que mal conseguem se concatenar uns aos outros. Como consequência, o palco ilimitado dos acontecimentos épicos dá lugar a um teatro estreito, confinado e repleto de sombras. Sobre esse novo palco, personagens tragicômicos se arriscam em números fadados ao fracasso.

Esses são alguns pontos, portanto, que serão detalhados e analisados nos capítulos que seguirão esta breve introdução. Neles, abordaremos as metamorfoses em suas particularidades e em suas semelhanças, tendo em vista seus efeitos na condução da narrativa e os aspectos formais que lhes garantem substância. Também discutiremos a repercussão das primeiras publicações de Rubião e o estranhamento causado na crítica devido à sua narrativa insólita e seus temas de preferência - como as metamorfoses. Além disso, dedicaremos um capítulo inteiro para o assunto da transformação animal, recurso constante do escritor. Como já se prevê 
por esta apresentação, sua obra também será, vez ou outra, comparada à de outros escritores com o intuito de enriquecer a análise de um assunto tão exigente e que mobilizou tantas criações diferentes ao longo da história literária. Por uma questão de economia e de pertinência ao assunto, daremos, obviamente, prioridade aos contos que, seja de maneira ostensiva, seja de maneira sutil, apresentam como assunto ou como recurso formal a metamorfose. 


\section{CAPÍTULO I: “O impasse angustiado da escrita e o caminho singular de Murilo Rubião"}

Que a tarefa do escritor termina com a sua vida, eis o que dissimula que, por essa tarefa, a vida dele resvala para o infortúnio do infinito.

(Maurice Blanchot)

Publicada, republicada e reescrita no decorrer de cinco décadas, a obra deixada por Murilo Rubião (1916 - 1991) surpreende por sua fidelidade a certos aspectos formais e temáticos que lhe garantiram a firmeza de um conjunto coeso em todos os seus elementos, apesar do longo tempo que separa o primeiro livro do último. Esse bloco espesso e pacientemente lapidado, controlado nos mínimos detalhes pelo estilo tenaz do autor e pelo aperfeiçoamento obsessivo de seus textos, resultou numa obra exígua em mais de um sentido. Em primeiro lugar, descontados os manuscritos divulgados após sua morte, o escritor mineiro deixou 33 contos para publicação (32 em livro e 1 conto inédito editado e publicado após sua morte). Quando comparados ao número de livros publicados em vida - foram sete no total -, podemos entrever a importância de seu trabalho de reescrita. Grande parte desses livros que sucederam a publicação de $O$ ex-mágico, de 1947, compõe-se de contos inéditos misturados com contos antigos revisados pelo próprio escritor e republicados, num processo que se acentuou nas suas últimas coletâneas. Portanto, o movimento de criação de Murilo Rubião caracterizou-se pelo constante retorno ao passado, tanto na retomada dos contos já publicados em outros livros, quanto no reaparecimento de temas, de figuras e de métodos de composição que sempre nortearam seu universo ficcional. Além disso, os contos ficavam, por vezes, mais de décadas na gaveta até serem concluídos e considerados prontos para circulação ${ }^{3}$.

Em segundo lugar, a aparente escassez da obra de Murilo Rubião está em sua dedicação exclusiva à composição de contos - quase todos muito semelhantes em tamanho e até mesmo em sua estruturação interna - levada com afinco até o fim de sua vida. Essa relutância em compor outros tipos de texto reforça a imagem de sua obra como um bloco maciço que deve ser visto em sua totalidade e por diferentes ângulos. Cada narrativa do escritor coloca-se como

\footnotetext{
${ }^{3}$ Como testemunho da meticulosidade e do longo processo de criação e de publicação de Murilo Rubião, há a crônica do poeta Paulo Mendes Campos a respeito da escrita do conto $O$ convidado, que levou 26 anos para vir a público. Ver em: CAMPOS, Paulo Mendes. Um conto em 26 anos. In: Os bares morrem numa quarta-feira: crônicas. São Paulo: Ática, 1980.
} 
um reflexo das outras ao mesmo tempo em que mantém de pé suas particularidades. Não houve rupturas de estilo na trajetória literária de Rubião. Em cada texto, suas linhas de força ficcionais sempre se metamorfosearam a fim de garantir novos personagens e novas situações, preservando, contudo, o impacto da brevidade, a unidade temática dos conflitos e a atmosfera espontaneamente insólita de seus contos (características que serão detalhadas e aprofundadas nos próximos capítulos deste estudo).

No entanto, a aparente miudeza de sua obra logo foi amplificada pelos críticos. Com isso, os contornos estreitos da narrativa muriliana ganharam novas proporções, ao mesmo tempo em que se viram valorizados por sua simplicidade fundamental. A reação da crítica literária contemporânea ao escritor e os diferentes caminhos trilhados por suas interpretações, desde a publicação de $O$ ex-mágico, funcionam como um termômetro eficiente para medir a complexidade que surge da aridez de sua ficção.

Traçar esses percursos críticos - muitas vezes contrastantes e, até mesmo, contraditórios entre $\mathrm{si}$ - e analisar as diferentes repercussões da obra não deixa de ser um exercício proveitoso para dar início à observação e à perfuração do bloco confeccionado pelo escritor. Tal tarefa será, portanto, um dos tópicos deste capítulo. Junto da recapitulação das características levantadas pela crítica, com a finalidade de alargar as discussões estabelecidas por ela, também comentaremos a disputa que se estabeleceu ao redor da obra de Murilo Rubião ora para filiá-lo à tradição europeia da literatura fantástica, ora para integrá-lo ao realismo maravilhoso latinoamericano. Por fim, abordaremos o problema da escrita metamórfica do escritor mineiro a partir da sua própria obra, que esteve em constante reconstrução e reestruturação ao longo de sua trajetória literária. Analisaremos alguns contos que, num exercício de metalinguagem, colocam no papel os louros e os reveses da criação artística e que tratam aberta ou implicitamente dos dilemas do escritor.

\section{Repercussão da obra e percalços da crítica}

Na correspondência trocada entre Murilo Rubião - então rapaz inexperiente do mundo das letras e cujos primeiros contos ainda não haviam sido publicados - e Mário de Andrade, conselheiro e comentarista favorito dos artistas brasileiros da época, já se fazem notar algumas observações à prosa do escritor mineiro que, por um tempo, seriam reproduzidas e intensificadas pela crítica, tanto em textos de jornais quanto no âmbito acadêmico. Ao mencionar algumas características dos contos de Rubião, o autor de Macunaíma mostra certo descontentamento pelo uso do fantástico como pano de fundo e meio estrutural da narrativa. 
Ele admite que não se sente apto para analisá-la uma vez que não enxerga outros textos similares no cenário brasileiro, buscando em Kafka seu único parâmetro. Assim, confessa ao jovem seu desconforto: "É que eu fico sempre numa enorme dificuldade de dar opinião pra esse gênero de criação em prosa a que estou denominando aqui de baseada no princípio da fantasia. O próprio Kafka, confesso a você que frequentemente me deixa numa insatisfação danada"4.

Com efeito, Mario não erra ao aproximar a obra do então estreante da literatura à do escritor tcheco. Essa conexão, apesar de ostensiva e até mesmo limitadora à época do lançamento de $O$ ex-mágico, mostrou-se bastante fecunda para a crítica posterior - como provaram os trabalhos de Davi Arrigucci Jr., Jorge Schwartz, José Paulo Paes, entre outros. O que nos chama a atenção, entretanto, é o desconforto de Mario de Andrade ao lidar com a literatura que, em suas palavras, se constrói a partir do "princípio da fantasia". Além da desconfiança e da insatisfação do paulista em relação à literatura dita fantástica, ao longo das cartas, percebe-se uma insinuação velada de que os contos de Murilo Rubião, assim como os de Kafka, seriam demasiadamente artificiais. Sua justificativa assinala, ainda, que os recursos fantasiosos dos dois contistas não o convence por serem irreais, "mas por não serem suficientemente irreais, suficientemente inesperados" $"$.

A recepção fria de Mario de Andrade, que insiste na sua imperícia e na sua desqualificação para avaliar, em suas palavras, contos tão deslocados do resto da produção literária brasileira - embora os avalie à medida que escreve as cartas -, revela mais de uma ambiguidade em seu conteúdo. A primeira delas surge, precisamente, da necessidade de afirmar sua incapacidade de julgamento ao mesmo tempo em que faz comentários preciosos para o trabalho criativo e para o amadurecimento de Murilo Rubião. Se, por um lado, essa hesitação confirma que a obra do escritor mineiro talvez sinalizasse novos caminhos para a literatura do país, por outro lado, também constata que ela não se manifestou desacompanhada, como um texto totalmente exótico, pois trazia dentro de si referências às tradições e ao cânone da arte algumas reconhecidas pelo próprio Mario - e dialogava com a obra de outros escritores contemporâneos.

A segunda ambiguidade pode ser conferida a partir da crítica publicada por Sérgio Milliet logo após o aparecimento de $O$ ex-mágico. Nela, Milliet afirma que "o livro desigual de Murilo Rubião [...], hesitante na realização técnica e artística e lembrando por demais as experiências de 22, contém, entretanto, alguns contos interessantes e um, pelo menos, delicioso:

\footnotetext{
${ }^{4}$ MORAES, Marco Antônio de (Org.). Mário e o pirotécnico aprendiz (Cartas de Mário de Andrade e Murilo Rubião). Belo Horizonte: Ed. UFMG; São Paulo: IEB-USP; São Paulo: Ed. Giordano, 1995, pg. 56.

${ }^{5}$ Idem, Ibidem. pg. 58.
} 
o que deu nome ao volume"6. Sem explicar os motivos que o levaram a traçar tal paralelo, o crítico alude ao Movimento Modernista de São Paulo como antepassado da obra de Rubião. Ora, ao estabelecer essa ligação, Milliet filia os contos recém-publicados à tradição legada, justamente, por Mario de Andrade. Além dessa comparação, há também em sua crítica outras referências literárias que auxiliam no entendimento da prosa muriliana. Por exemplo, a "atmosfera surrealista" instaurada em certos contos que "são pequenos poemas em prosa às vezes, devaneios sem ligação aparente, imagens soltas cuja fluidez é quebrada de quando em quando por violentos absurdos que são como advertências de um pudor arisco contra o sentimentalismo ameaçador"7.

De maneira não intencional, os comentários de Milliet escancaram a estranheza causada pela postura de Mario diante do jovem estreante das letras. Como o autor de Macunaíma, um dos textos mais inovadores e irrealistas da literatura brasileira do século XX, pôde manter-se esquivo, quase indiferente, a uma obra tão incomum em sua idealização e em sua composição? Se Sérgio Milliet observa, sem muito entusiasmo, que as experiências modernistas de 22 abriram caminhos suficientes para que a obra de Murilo Rubião sobreviesse mais de duas décadas depois, qual o estranhamento de Mario de Andrade ao deparar-se com ela?

A resposta a essas perguntas pode ser vislumbrada nas três principais comparações realizadas por Mario e por Milliet em relação aos contos de Rubião: o universo fantástico ao gosto de Kafka, a atmosfera surrealista de sua ficção e seu estilo próximo, muitas vezes, do poema em prosa. Deixando de lado o mérito ou a pertinência das colocações, os três itens citados evidenciam uma possível relação de $O$ ex-mágico com manifestações literárias que tiveram pouco impacto no cenário brasileiro. Há, de certa maneira, uma acusação implícita de estrangeirismo vinda dos dois escritores veteranos em direção ao novato. Para Mario de Andrade, por exemplo, parece não importar que a obra literária tenha intenções realistas ou fantásticas, desde que estas sejam manifestadas com as cores locais, por meio do universo mítico-folclórico do país como no romance-rapsódia de sua autoria. Já a dimensão insólita de Murilo Rubião, muito próxima do prosaísmo urbano de qualquer cidade mundo afora, das repartições públicas e da burocracia moderna, parece-lhe dissimulada e convencional. Nesse sentido, a afirmação de Sérgio Milliet sobre a ligação de Rubião com os modernistas de 22 tem seu significado amplificado, pois, além de uma admissível semelhança estética, haveria

\footnotetext{
6 MILlIET, Sérgio. O Ex-Mágico. In: Estado de São Paulo, 3 - XII - 47. Disponível em: http://www.murilorubiao.com.br. Último acesso: 19/06/2018.

${ }^{7}$ Idem, ibidem.
} 
também, em ambos, semelhanças ideológicas marcadas por uma pretensão vanguardista importada da Europa.

As proposições de Mario e de Milliet fazem coro ao restante dos trabalhos que circularam no período. Desse modo, tanto a semelhança kafkiana como a atmosfera surrealista vão dar o tom dos primeiros comentários críticos a propósito da ficção do escritor mineiro. Sandra Regina Chaves Nunes comenta o impacto inicial que seguiu a divulgação de $O$ exmágico e ressalta a influência da comparação de Kafka nos comentários publicados nos jornais da época. A autora elenca alguns críticos que analisaram o primeiro de livro de Murilo Rubião com o intuito de mostrar a oscilação repetitiva entre aqueles que enxergam influências do escritor tcheco - presença unânime nessa primeira fase - e aqueles que veem referências ao movimento surrealista em suas manifestações plásticas e literárias:

O fantástico também foi tema de muitas das críticas escritas sobre sua obra. Aliás, poderemos notar uma diversidade de nomenclatura para o tratamento dado ao "real" pelo autor. Sua obra foi definida como pertencente ao fantástico, ao realismo mágico, ao absurdo, ao surreal. Todos os artigos publicados após o lançamento de O ExMágico (1947) falam da semelhança de Murilo com o escritor tcheco Kafka. Esta comparação, ou referência a Kafka, só será deixada de lado posteriormente, com trabalhos que se voltarão para a obra do escritor mineiro e suas particularidades. ${ }^{8}$

Entre os nomes citados por Nunes como propagadores das primeiras impressões sobre os contos murilianos estão Álvaro Lins, Oscar Mendes, José Augusto Carvalho e, também, Sérgio Milliet. Em todos eles, destaca-se a ânsia de filiar $O$ ex-mágico a alguma corrente literária próxima, tendo em vista sobretudo aquilo que tinha sido produzido na Europa nas décadas anteriores ao lançamento do livro. Como apontado na última citação, os comentaristas brasileiros sentem-se desnorteados pela necessidade de definir o "elemento fantástico" arquitetado por Rubião em sua prosa e mantêm-se reticentes diante da qualidade artística e da pertinência desse tipo de produção? .

\footnotetext{
${ }^{8}$ NUNES, Sandra Regina Chaves. Visões da crítica. Disponível em: http://www.murilorubiao.com.br. Último acesso: 19/06/2018

${ }^{9}$ Segundo Sandra Regina Chaves Nunes, a falta de comunicação entre obra e interpretação foi intensificada pela própria crise que a crítica literária enfrentava na década de 40 , quando estava em disputa a crítica dos tradicionais "homens das letras" e a crítica especializada que começava a despontar. Para ampliar o problema e dar novas justificativas à divergência entre a produção literária de Murilo Rubião e a sua interpretação, Nunes faz um paralelo com o desenvolvimento da crítica literária na América Latina, dialogando de perto com Octavio Paz: "Sobre o papel da crítica, a observação de Octavio Paz de que na América Latina como um todo há um descompasso entre a criação literária e a reflexão crítica sobre essa criação parece ainda válida. A deficiência ou a estagnação do discurso crítico é vista pelo autor como consequência da falta de diálogo, do isolamento de ideias e da desconsideração de projetos interpretativos de terceiros por parte dos intelectuais latino-americanos. Em função desses fatores, há uma continuidade de propostas críticas sem uma reflexão adequada nas discussões sobre questões de cultura e literatura latino-americanas. Podemos afirmar que é exatamente essa a impressão que temos quando nos deparamos com a crítica às obras de Murilo Rubião e Jorge Miguel Marinho. As reflexões sobre o fantástico e realismo mágico têm um distanciamento considerável entre elas". Ver em: Idem, ibidem.
} 
Ante esse cenário marcado pela desconfiança, a voz de Otto Lara Resende destoa com seus elogios entusiasmados ao livro de Rubião. O escritor salienta a complexidade aparentemente simples dos contos de $O$ ex-mágico e a sua força simbólica, além de louvar a iniciativa ambiciosa de sua prosa fantástica e, ao mesmo tempo, trivial. Resende também aponta a atualidade do livro, destacando que ele está colado com os grandes problemas da modernidade e com os dilemas que afligem seus indivíduos. Em vez de aproximar Murilo Rubião somente de Franz Kafka - o que não deixa de ser feito no artigo - ou dos artistas surrealistas, seu conterrâneo mineiro vincula-o à estirpe dos escritores "inconformados", que teve Rimbaud como o seu último representante de peso. De kafkiano nos contos de Murilo Rubião, ainda segundo Otto Lara Resende, há sobretudo o seu herói que, como os protagonistas do escritor tcheco, delineia-se como um "solitário, triste, desesperado. Um poderoso e viril herói do subsolo, perseguido, ainda aí, nesse 'terrier' em que se situa, por sombras exasperantes e

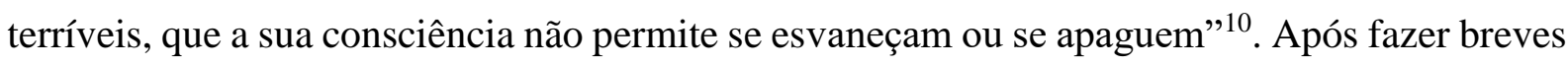
considerações a respeito dos contos, da força de suas histórias que se dispõem como um "testemunho artístico de nosso tempo" e que não deixará nenhum leitor indiferente, seja pela adesão, seja pela repulsa, o escritor conclui seu artigo reforçando a imprescindível modernidade de Murilo Rubião. Por fim, o último elogio do texto remete-nos à discussão iniciada a partir dos comentários realizados por Mario de Andrade e por Sérgio Milliet. Resende enxerga na obra de Murilo Rubião uma natureza cosmopolita e inovadora, atenta ao "misterioso jogo do destino do homem, do nosso destino", fator que talvez prejudique sua repercussão e posterior aclamação, pois "na literatura brasileira, de onde a civilização parece ausente, $O$ ex-mágico é um livro raro. Um livro que merece uma consagração e que, por isso mesmo, talvez não a obtenha"11.

Apesar do entusiasmo de Otto Lara Resende, a apatia do restante da crítica, logo após a publicação da primeira coletânea de contos de Murilo Rubião, não favoreceu sua consolidação no circuito literário brasileiro. A previsão funesta de Resende parecia de fato se cumprir. Como se não bastasse a falta de apoio dos intelectuais, $O$ ex-mágico também não obteve sucesso comercial e precisou do auxílio do próprio autor para garantir sua circulação. As mesmas circunstâncias se repetiriam - de maneira ainda mais intensa - nas duas décadas posteriores, quando foram lançados os livros A estrela vermelha (1953) e Os dragões e outros contos

\footnotetext{
${ }^{10}$ RESENDE, Otto Lara. Adesão ao herói de nosso tempo. In: CABRAL, Cleber Araújo (org.). Mares interiores: correspondência de Murilo Rubião \& Otto Lara Resende. Belo Horizonte: Autêntica Editora/Editora UFMG, 2016, pg. 201.

${ }^{11}$ Idem, ibidem. pg. 205.
} 
(1965). Os poucos leitores e o ritmo lento de criação resultaram na quase ausência de interpretações tanto da crítica especializada dos jornais, como da crítica acadêmica.

A falta de interesse por sua obra não impediu, porém, que o escritor continuasse trabalhando em novos contos e corrigindo os antigos. Malgrado os longos intervalos entre as publicações, consequência de seu perfeccionismo e de sua angústia no trato com a escrita, nada foi suficiente para arrancá-lo da literatura. Outro motivo que contribui para a marcha lenta de sua produção literária pode ser visto no papel secundário que esta exercia em sua vida - Rubião, afinal, trabalhou no serviço público e no jornalismo por muitos anos, sendo o criador do Suplemento Literário na Imprensa Oficial de Minas Gerais. Ao traçar os primeiros percalços da trajetória de Murilo Rubião no mundo das letras, Humberto Werneck comenta sua aventura solitária ressaltando o papel assumido pelo autor mineiro na publicação e na divulgação de sua própria obra:

\begin{abstract}
Seu primeiro livro, $O$ ex-mágico, saiu em 1947, pela Universal, pequena editora do Rio de Janeiro (publicou apenas quatro títulos, entre eles Sagarana, na estreia de Guimarães Rosa, em 1946), com tiragem de 2 mil exemplares, dos quais quinhentos foram bancados pelo próprio Murilo, que além disso, antevendo um humilhante encalhe, comprou outros mil para distribuir. [...] O segundo livro, A estrela vermelha, de 1953, teve tiragem confidencial, de 116 exemplares. Do terceiro, Os dragões $e$ outros contos, de 1965, tiraram-se mil, que mal chegaram a algumas livrarias, pois não saíram por uma editora comercial, e sim pela Imprensa Oficial do Estado de Minas Gerais. $^{12}$
\end{abstract}

O prognóstico de insucesso já parecia irrevogável quando fatores externos despertaram nas editoras - e, como resultado disso, nos leitores e na crítica - o interesse pelo universo insólito da obra de Murilo Rubião. Em meados da década de 60, o grande fascínio em torno do realismo maravilhoso latino-americano, excitado por nomes como Julio Cortázar e Gabriel García Márquez, tanto no próprio continente, quanto na Europa, teve como efeito colateral a redescoberta do escritor mineiro uma década mais $\operatorname{tarde}^{13}$. À primeira vista, não poderia haver qualquer indício de aproximação entre as duas obras senão pela naturalidade dos elementos fantásticos dentro de suas histórias. Afinal, como um escritor do Brasil, afastado dos centros culturais de seu próprio país e devedor, em grande parte, da Bíblia, de Machado de Assis, de Dom Quixote, das Mil e uma noites e de outras narrativas clássicas para a construção de sua obra, poderia ter antevisto um movimento literário que pôs, finalmente, a América Latina em evidência na cena literária mundial? Como Murilo Rubião, igualmente influenciado pelas

\footnotetext{
${ }^{12}$ WERNECK, Humberto. Prefácio: A aventura solitária de um grande artista. In: RUBIÃO, Murilo. O homem do boné cinzento e outros contos. São Paulo: Companhia das Letras, 2007, pg. 8.

${ }^{13}$ Fator decisivo para a retomada do interesse por Murilo Rubião foram as duas publicações da Editora Ática em 1974: O pirotécnico Zacarias e A casa do girassol vermelho.
} 
historietas mineiras de sua infância ${ }^{14}$, apinhadas de personagens da tradição oral, pôde antecipar o gênero que dominaria a literatura hispânica duas décadas após a publicação de seu primeiro livro?

Segundo alguns críticos, entre eles Humberto Werneck, Murilo Rubião deve ser considerado um participante avant la lettre do realismo maravilhoso. A despeito das diferenças entre o escritor brasileiro e seus vizinhos da América Hispânica (diferenças que serão detalhadas mais para frente, ainda neste capítulo), Werneck reconhece como "é espantoso verificar, hoje, o quanto Murilo Rubião foi ignorado, durante tantas décadas, quando na verdade antecipara entre nós um tipo de literatura que só vinte anos mais tarde daria renome internacional a seus confrades hispano-americanos"15. Por tais razões que, de maneira direta, não lhe concerniam, Murilo Rubião passa da condição de Kafka ou de surrealista brasileiro ao status de inovador da literatura nacional. Ao deixar de ser visto pela crítica como um herdeiro anônimo do espólio deixado pelas vanguardas europeias do começo do século XX - todas infrutíferas no campo literário do Brasil -, o autor triunfa e transforma-se num dos fundadores de um novo tipo de ficção no país, alcançando o reconhecimento do público e da crítica.

Em linhas gerais, são esses os atributos destacados por Antonio Candido ao comentar o papel de Murilo Rubião na nova narrativa do século XX. O crítico posiciona $O$ ex-mágico como uma das obras mais inovadoras e transgressoras surgidas nas décadas de 40 e 50, ao lado de Perto do coração selvagem, de Clarice Lispector, e de Grande Sertão: Veredas, de Guimarães Rosa. Os três livros, segundo Candido, foram responsáveis por mudanças importantes no plano formal da produção literária da época, cada um à sua maneira.

A Murilo Rubião, coube-lhe a honra de instaurar no Brasil a "ficção do insólito absurdo" e de quebrar a unanimidade do plano realista de nossa literatura, uma vez que o autor "elaborou os seus contos absurdos num momento de predomínio do realismo social, propondo um

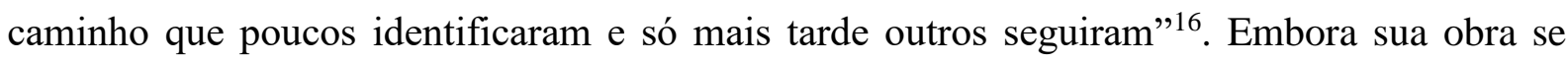

\footnotetext{
${ }^{14}$ Nas entrevistas e nos depoimentos concedidos durante sua trajetória na literatura, Murilo Rubião sempre salientou a relevância dessas fontes para a criação de seus contos desde o primeiro volume. Ele afirma, por exemplo, que não conhecia a obra de Franz Kafka até a confrontação operada por Mario de Andrade em suas cartas. Seu universo fantástico seria, antes de tudo, uma continuação das histórias que ele escutou, desde a infância, no mundo rural de Minas Gerais, misturadas com sua leitura da Bíblia e de outros clássicos da literatura: "Minha opção pelo fantástico foi herança da infância, das intermináveis leituras de contos de fadas, do Dom Quixote, da História Sagrada e de As Mil e uma Noites. Ainda: porque sou um sujeito crédulo e nunca me espanto com o sobrenatural, com os instantes mágicos. E isso tudo aliado a uma invencível sedução pela atmosfera onírica das coisas. A mesma credulidade com que ouvia as infindáveis histórias de Maria do Chico, uma preta velha, me acompanha até hoje e está presente em toda a minha literatura. Ver em: RUBIÃO, Murilo. Depoimento e vida. In: CABRAL, Cleber Araújo (org.). Op. cit. pg. 207.

${ }^{15}$ WERNECK, Humberto. Op. cit. p. 8.

${ }^{16}$ CANDIDO, Antonio. A nova narrativa. In: A educação pela noite. 6. ed. Rio de Janeiro: Ouro sobre Azul, 2011, pp. 251-252.
} 
mantenha restrita ao território nacional e não repercuta como os livros de Cortázar e de Márquez, Candido traça uma ligação entre as duas e louva o fato de Rubião ter antecipado esse tipo de ficção que, com o passar do tempo, passou de exceção à quase regra no continente americano. Todavia, seu pioneirismo pode ser encarado como um fruto do acaso, uma vez que, ainda segundo Antonio Candido, "foi a voga da ficção hispano-americana que levou para este rumo o gosto dos autores e do público" ${ }^{17}$. A força dessa coincidência aparece de maneira ainda mais evidente quando defrontamos o ano de publicação de $O$ ex-mágico com o ano de lançamento de alguns dos primeiros livros da "ficção do insólito absurdo" - por exemplo, as Ficções de Jorge Luis Borges, de 1944, e o conto Casa tomada de Julio Cortázar, de 1946. De fato, havia uma consonância entre os contos de Murilo Rubião e a obra de nossos vizinhos de língua espanhola que só foi percebida décadas depois, com o boom do realismo maravilhoso.

Flavio García, ao comentar a concomitância de publicações que prescindiram do pacto realista com a literatura a fim de instaurar uma nova ordem ficcional - pautada no insólito, no sobrenatural ou no absurdo -, ressalta a importância, além dos dois autores argentinos, da obra do escritor mexicano Alfonso Reyes. Esses três escritores da América Hispânica, juntos de Murilo Rubião no Brasil, teriam preparado o terreno do que se desenvolveu a posteriori no realismo maravilhoso. Embora não seja possível enquadrá-los num mesmo movimento literário e a aproximação entre eles deva ser cautelosa, os quatro, de fato, inauguraram um novo roteiro para a produção literária do continente:

\begin{abstract}
Ainda que esses três escritores hispano-americanos, dois deles argentinos - Borges e Cortázar - e o outro mexicano - Reyes - não se enquadrem isonomicamente em uma mesma faixa de produção literária delimitável de modo homogêneo, todos se inscrevem no conjunto de ficcionistas cuja obra tem emergência no entorno da metade do século XX, sendo, portanto, contemporâneos de Murilo Rubião; e até Reyes, falecido em 1959, viveu as mesmas experiências coletivas - inspiradas pelo e aspiradas do imaginário que deu forma ao boom dos realismos adjetivados (mágico, maravilhoso, fantástico, feérico) do século XX. Aliás, não é excessivo reiterar que "O ex-mágico da Taberna Minhota", de Murilo Rubião, tem sua primeira edição datada de 1947 , já ao final da primeira metade do Novecentos. ${ }^{18}$
\end{abstract}

Deixando de lado, por ora, o contexto amplo da América Latina e retomando as considerações de Antonio Candido, não obstante as inúmeras diferenças entre os três escritores citados como fundamentais no estabelecimento da nova narrativa brasileira, todos contribuíram, também, para mudanças que estão situadas além dos limites do campo formal. De acordo com o crítico, os três se distanciaram de "preconceitos provincianos" e da posição marginalizada da literatura latino-americana, que, por muito tempo, preferiu prestigiar somente o pictórico e o

\footnotetext{
${ }^{17}$ Idem, ibidem. pg. 255.

${ }^{18}$ GARCÍA, Flavio. Aspectos dos discursos fantásticos contemporâneos, pegados "às unhas", em um conto "não pronto para a publicação" de Murilo Rubião. In: GARCÍA, Flavio, BATALHA, Maria Cristina (org.). Murilo Rubião: 20 anos depois de sua morte. Rio de Janeiro: EdUERJ, 2013, p. 17.
} 
exótico local, ao renovar um processo iniciado por Machado de Assis no século XIX. Assim, tanto Clarice, como Guimarães e Murilo Rubião buscaram uma "linguagem que procura dar conta dos problemas que são de todos os homens, em todos os quadrantes, na moldura dos costumes da civilização dominante, que contrabalança o particular de cada zona" ${ }^{19}$. Por meio de inovações formais que se afastam do pastiche de gêneros tradicionais e da influência francesa, os três escritores, tal qual Machado de Assis, lograram atingir a universalidade da obra de arte e inovaram a produção literária no Brasil ao abrir novas possibilidades ficcionais.

Além de dar novo fôlego à crítica, a visão complexa de Antonio Candido a respeito da obra de Murilo Rubião afasta, por fim, os preconceitos que nortearam os primeiros comentários a seu propósito. Enxergando a inovação contida em $O$ ex-mágico, o crítico abre espaço para novas possibilidades de interpretação. Seus comentários relativos ao provincianismo da literatura latino-americana podem ser lidos, igualmente, como uma reprovação aos primeiros textos analíticos sobre a narrativa muriliana, embora não tenha sido esse o seu objetivo. Candido escancara a má vontade e a desconfiança da crítica diante das novidades apresentadas, sobretudo, por Guimarães e Rubião, e oferece uma justificativa viável para o tom reprovador que as sucederam e que atrasaram sua circulação. Não à toa, ambos levaram anos para alcançar o reconhecimento devido.

A reaparição de Murilo Rubião promovida por Antonio Candido - e também por outros críticos como Nelly Novaes Coelho (cujas contribuições serão esmiudadas em outros capítulos e auxiliarão este trabalho), que publicou uma crítica sobre o autor ainda na década de 60, após o lançamento do livro Os dragões e outros contos, em 1965 - impulsionou novas análises, a divulgação de textos críticos em jornais e, inclusive, teses vindas das universidades. Também foram realizadas as primeiras traduções para o público estrangeiro, mesmo sem a repercussão dos nossos vizinhos, conforme dito anteriormente. Por sua vez, o mercado editorial brasileiro alcançou bons números com as novas coletâneas de contos de Rubião. Tal processo de retomada - que contou com o apoio de nomes de peso do mundo acadêmico e do mundo editorial - é descrito por Jorge Schwartz, crítico fundamental durante o reestabelecimento do autor e a sua passagem para clássico da literatura:

Esquecido do grande público durante quase três décadas, Murilo Rubião ressurgiu com extraordinário sucesso na edição de O pirotécnico Zacarias, de 1974, da Editora Ática: em pouco tempo foram vendidos mais de 100 mil exemplares. Depois vieram as primorosas traduções em inglês, de Thomas Colchie, The Ex-Magician and Other Stories (1979); para o alemão [...], para o checo [...] e para o espanhol [...]. Se conforme a reflexão de Borges, aquilo que confere a uma obra o status de "clássica" não é o cânone instituído pelos historiadores da literatura nem pelos defensores da tradição, mas sim a capacidade de revelação e renovação derivada do ato da leitura,

\footnotetext{
${ }^{19}$ CANDIDO, Antonio. Op. cit. pg. 245-246.
} 
podemos então afirmar, sem dúvida, que Murilo Rubião é hoje um clássico do conto brasileiro do século XX. ${ }^{20}$

O crescente interesse por sua obra não resultou, contudo, no aceleramento do ritmo de produção por parte do autor. O próprio título do livro de 1974 já indica que, apesar do sucesso de público, parte de suas histórias estava sendo reeditada, pois o conto O pirotécnico Zacarias já integrava a primeira coletânea de Rubião, de 1947. Isso voltará a se repetir nos livros seguintes, em que poucos contos inéditos aparecerão misturados com outras narrativas já conhecidas dos leitores, ligeiramente alteradas devido ao intenso trabalho de reescrita e de revisão feito pelo autor. O que ganha destaque durante essa época, portanto, são as contribuições críticas que despontaram em livros e em periódicos. Na década de 70, Davi Arrigucci Jr., marcadamente influenciado pela filosofia de Sartre, faz veicular seus primeiros textos a propósito dos contos de Rubião. Alguns anos depois, em 1981, é publicado o livro Murilo Rubião: A Poética do Uroboro, de Jorge Schwartz, primeiro trabalho acadêmico dedicado unicamente à obra do escritor mineiro.

Até a sua morte, em 1991, o escritor ainda publica mais quatro coletâneas de contos após o livro de 1974, uma delas comentada por Schwartz. Esse foi, sem dúvida, o período mais profícuo de publicações do autor, apesar de todas elas reproduzirem o mesmo esquema das anteriores, que misturam contos inéditos com contos reeditados. Rubião, enfim, viu-se alçado a uma nova posição dentro da cena literária do Brasil e, com a multiplicação de textos críticos e a riqueza de suas diferentes visões, as perguntas que haviam sido lançadas nos primeiros comentários à sua obra começaram a ser respondidas.

De fato, seus contos dialogavam com o surrealismo europeu, com o estilo kafkiano, com as histórias tradicionais do interior de Minas Gerais, com a Bíblia, com a literatura clássica, com os contos de fada e, até mesmo, com o realismo maravilhoso que só se consolidaria décadas depois. No entanto, nenhuma dessas conversas diminuía o valor de sua obra e, pelo contrário, tornavam-na ainda mais rica e complexa. A obra de Murilo Rubião está em todas essas instâncias e, simultaneamente, não pertence a nenhuma delas. Ela testemunha metamorfoses sociais e artísticas que, como em qualquer período de mudança, prendem-na ao passado ao mesmo tempo em que dirigem seu olhar para o futuro. Não por acaso, outros escritores passaram por processos semelhantes em suas criações, durante a mesma época e sem se conhecerem. Afigura-se impossível, portanto, a tarefa de filiar a prosa de Rubião a apenas uma tradição, assim como soa descabido valorizar em demasia seu papel como um dos

${ }^{20}$ SCHWARTZ, Jorge. Murilo Rubião: um clássico do conto fantástico. In: RUBIÃO, Murilo. O pirotécnico Zacarias e outros contos. São Paulo: Companhia das Letras, 2007, pp. 109-110. 
inauguradores do realismo maravilhoso latino-americano. No entanto, de maneira cautelosa e ponderada, analisar a sua obra exige que esses exercícios sejam realizados e que as conexões sejam estabelecidas.

\section{Obra de muitos espaços (parte I): Murilo Rubião e o fantástico tradicional}

A viagem de trem de um homem consumido pelo ciúme desencadeia a trama simples, porém insólita, do conto A noiva da casa azul. Vindo do Rio de Janeiro, o narrador protagonista dirigese à cidadezinha de Juparassu - um vilarejo fincado no meio da serra onde ele nasceu e passou a infância e a adolescência - com o objetivo de buscar explicações para certos acontecimentos recém-descobertos. Seu descontrole é resultado de uma carta enviada por sua noiva Dalila, ainda moradora de Juparassu, em que ela lhe relata alguns momentos íntimos vividos com seu antigo noivo. Mas sua raiva logo arrefece aos primeiros sinais das paisagens serranas, que estimulam lembranças devaneadoras dos dias passados junto de Dalila. Sem demora, situações tipicamente novelescas vêm à tona - a rixa das duas famílias, os cenários interioranos, o triunfo do amor. Confundido, ao chegar na estação de destino, com um engenheiro que estava encarregado de fazer alterações na linha e cheio de ansiedade para rever a noiva, de quem está afastado há mais de um ano, o narrador descobre que Juparassu desapareceu do mapa. Decidido a comprovar isso com os próprios olhos, ele se dirige apressado à sua antiga cidade e constata que, de fato, não havia ali senão construções abandonadas e casas de campo em ruínas. Quando o rapaz encontra, nas redondezas de sua antiga casa, um colono que permaneceu na região, este lhe explica que o vilarejo fora evacuado há muitos anos por causa de um surto de febre amarela. Preocupado com o paradeiro de Dalila, ele também descobre que sua noiva era uma das vítimas da doença. Além disso, o narrador é notificado de que ele próprio ficara gravemente doente e que fora levado às pressas para um hospital longe dali. Segundo o colono, nunca chegaram notícias de seu estado de saúde após a partida.

O desfecho do conto, separado do resto por asteriscos, opera uma mudança significativa na narração do protagonista. Se todos os fatos relatados até então tinham sido expostos no tempo pretérito, o narrador passa a contar os últimos acontecimentos na voz presente, entrecortada por lembranças de seus momentos com Dalila, na voz passada. Exasperado pela morte da amada e pela situação fantasmagórica em que se encontra, ele grita e procura pela noiva dentro da decadente Casa Azul, onde Dalila vivia.

Descolorida e quieta a Casa Azul está na minha frente. Caminho por entre os seus destroços. A escadinha de tijolos semidestruída. Aqui nos beijamos. Beijamo-nos no alpendre, cheio de trepadeiras, cadeiras de balanço, onde, por longa horas, ficávamos 
assentados. Depois do alpendre esburacado, o corredor. Dalila me veio fortemente. Subo a custo os degraus apodrecidos da escada de madeira. Chego ao quarto dela: teias de aranha. Vazio, vazio, meu Deus! Grito: Dalila, Dalila! Nada. Corro aos outros quartos. Todos vazios. Só teias de aranha, as janelas saindo das paredes, o assoalho apodrecendo. ${ }^{21}$

Esse parágrafo expõe a diminuição da distância que parecia haver entre o tempo da história e o tempo da narração, que encolhe abruptamente e, por fim, funde as duas dimensões. A ruptura causada pela última parte do conto intensifica a permanência do narrador dentro da casa e, por conseguinte, dentro da situação narrada. A Casa Azul ganha proporções aterrorizantes quando encarada pelos olhos de quem está falando, quando descrita pela testemunha de um cenário lúgubre, asfixiante e vertiginoso - similar à casa de Usher -, do qual se deve escapar na mesma hora. A mudança para o presente descontrola uma história que parecia equilibrada pela passagem do tempo, colocando sob suspeita a autoridade do narrador em relação aos fatos relatados. Como aponta Alcmeno Bastos a respeito da causalidade (ou falta de causalidade) que orienta as tramas do autor: "em um quadro temporal em que se torna difícil, senão impossível, assegurar que o fato presente antecede realmente o que vem depois, ou que este não ocorreu antes daquele, perdem-se os fios da lógica e o absurdo se instaura soberano" 22 . A partir disso, estabelece-se uma atmosfera de insanidade, de algo que escapa às explicações racionais e que pode apresentar características sobrenaturais.

A transformação brusca na dimensão temporal do conto acarreta, por sua vez, no surgimento e na urgência de muitas questões que antes estavam escondidas nos detalhes. Como afirma Anatol Rosenfeld a respeito da voz narrativa situada no presente, "quanto mais o narrador se envolve na situação, através da visão microscópica e da voz do presente, tanto mais os contornos nítidos se confundem; o mundo narrado se torna opaco e caótico" 23 . Tal opacidade caótica do desfecho do conto desperta questões que, se não eram urgentes e se encontravam em estado de latência, agora já são imperativas. Há realmente fantasmas na casa ou isso não passa de um delírio do jovem apaixonado? Quem é e de onde vem, de fato, esse rapaz? O que ocasionou sua perda de memória? Ele realmente se curou da febre amarela ou teve o mesmo destino da jovem? Todas essas perguntas são deixadas em suspenso pelo conto e todos os elementos anteriores ao desfecho são postos em xeque a partir da revelação do colono e do

\footnotetext{
${ }^{21}$ RUBIÃO, Murilo. A noiva da casa azul. In: Murilo Rubião: obra completa. São Paulo: Companhia das Letras, 2010, pg. 168.

${ }^{22}$ BASTOS, Alcmeno. Murilo Rubião e a questão da causalidade. In: GARCÍA, Flavio, BATALHA, Maria Cristina (org.). Op. cit. pg. 71.

${ }^{23}$ ROSENFELD, Anatol. Reflexões sobre o romance moderno. In: Texto/Contexto I. 5. ed. São Paulo: Perspectiva, 2013, pg. 92.
} 
descontrole do narrador - a carta, o ciúme deste pelo antigo noivo de Dalila, a história de amor entre os dois.

Entretanto, a suspeita de que o narrador não está em plena posse de suas faculdades mentais já se anunciava desde o início da narrativa, quando ele ainda se encontrava no trem rumo a Juparassu. Tomado de ciúme por Dalila, ele sentia "Uma raiva incontrolável, que se extravasava ao menor movimento dos outros viajantes, tornando-me grosseiro, a ponto dos meus vizinhos de banco sentirem-se incomodados, sem saber se estavam diante de um neurastênico ou débil mental ${ }^{24 "}$. Mais para frente, o confronto com o chefe do trem e o agente da estaçãozinha próxima de Juparassu - aquele que o confunde com o engenheiro de trilhos também dará indícios do descontrole reprimido a custo pelo protagonista, que parece aumentar cada vez que lhe é perguntado se, de fato, ele estava se dirigindo à cidade abandonada. Diante do espanto geral, o narrador passa a duvidar da sanidade mental dos outros: "Tive um momento de hesitação. Estaria falando com um cretino ou fora escolhido para vítima de desagradável brincadeira? O homem, entretanto, parecia uma pessoa normal"25.

Com efeito, o clima de hesitação domina o conto em sua segunda metade ${ }^{26}$. A narrativa se equilibra numa linha tênue que separa os fatos como são contados - ou seja, a aceitação do insólito - e uma tentativa de explicação racional a partir de certos dados lançados ao longo da história - neste caso, a insanidade do protagonista. Cabe ao leitor, portanto, a tarefa de se decidir entre um dos caminhos ou de se manter na via da ambiguidade. Dessa maneira, A noiva da casa azul retoma procedimentos da literatura fantástica europeia que despontou no final do século XVIII e teve seu auge no XIX, a partir de nomes como E. T. A. Hoffmann, Edgar Allan Poe, Henry James, Guy de Maupassant e muitos outros. Em comum, todos eles criaram narrativas em geral, textos curtos, como contos e novelas - nas quais a racionalidade burguesa do homem do século XIX - habitante de centros urbanos familiarizado com a realidade moderna chocava-se com eventos sobrenaturais que não poderiam ser explicados pela ciência. Tzvetan Todorov, por exemplo, afirma que essa modalidade da literatura fantástica surgiu como resíduo de um século extremamente racional voltado sobretudo à técnica: “O século XIX vivia, é

\footnotetext{
${ }^{24}$ RUBIÃO, Murilo. A noiva da casa azul. In: Op. cit. pg. 164.

${ }^{25}$ Idem, ibidem. pg. 166.

${ }^{26}$ Sobre a importância da hesitação por parte do leitor no modo de leitura de textos fantásticos do Setecentos e do Oitocentos, Tzvetan Todorov vê nessa presunção de um "leitor virtual" uma das funções textuais mais importantes entre todas que dão vida ao gênero: "O fantástico implica pois uma integração do leitor no mundo das personagens; define-se pela percepção ambígua que tem o próprio leitor dos acontecimentos narrados. É necessário desde já esclarecer que, assim falando, temos em vista não este ou aquele leitor particular, real, mas uma "função" de leitor, implícita no texto [...]. A hesitação do leitor é pois a primeira condição do fantástico. TODOROV, Tzvetan. Introdução à literatura fantástica. Trad. Maria Clara Correa Castello. 3. ed. São Paulo: Perspectiva, 2008.
} 
verdade, numa metafísica do real e do imaginário, e a literatura fantástica nada mais é que a má consciência desse século XIX positivista"27.

O próprio tema da construção mal-assombrada e em ruínas, que já fazia sucesso nos romances góticos de Ann Radcliffe e cuja tradição é continuada por Poe e por James, revela a filiação de A noiva da casa azul à narrativa fantástica do XIX. A presença ou não do fantasma de Dalila na Casa Azul origina a inquietação do leitor e a sensação de horror, reforçado pela exaltação do noivo: "Volto ao quarto dela: parece que Dalila está lá e não a vejo. O seu corpo miúdo, os olhos meigos, os cabelos dourados. Abraça-me e não sinto os seus braços”. A agonia aumenta a cada frase, o que resulta na fuga desesperada do narrador, que não consegue mais suportar a sucessão de imagens que se confundem dentro de sua cabeça - a decadência da Casa Azul misturada com as lembranças de seu passado junto de Dalila ${ }^{28}$. Como afirma Remo Ceserani ao abordar os temas clássicos dos contos fantásticos anteriores à obra de Murilo Rubião: “A cena da aparição repentina e inesperada de um estrangeiro no espaço doméstico de uma casa é quase um estereótipo, presente na psicologia e no imaginário cultural das comunidades humanas antes ainda que nos textos literários, artísticos ou cinematográficos" ${ }^{29}$.

Podemos considerar o conto A noiva da casa azul, porém, uma exceção dentro do universo ficcional de Murilo Rubião. Embora o choque entre a racionalidade dos centros urbanos e as superstições do interior seja constante em sua obra - remetendo a preocupações que irromperam, como vimos, a partir da produção dos escritores da literatura fantástica do Novecentos -, a hesitação por parte do leitor não costuma ser o seu alvo. Na maioria dos casos, o elemento insólito sobrepõe-se de maneira ostensiva à realidade reconhecível pelo leitor, ao seu mundo empírico. Não sobra espaço, portanto, a dúvidas sobre a existência do sobrenatural e do inexplicável (traço importante de seus contos que será detalhado no segundo capítulo). . A narrativa fantástica. In: As estruturas narrativas. Tradução de Leyla Perrone-Moisés. 4. ed. São Paulo: Perspectiva, 2006, pg. 166.

${ }^{28}$ Italo Calvino ressalta a importância da construção de imagens - de figuras que devem saltar à vista dos personagens e, consequentemente, dos leitores - na narrativa fantástica do Oitocentos. Para o escritor, tudo nesse gênero está condicionado à visão: "[...] o verdadeiro tema do conto fantástico oitocentista é a realidade daquilo que se vê: acreditar ou não acreditar nas aparições fantasmagóricas, perceber por trás da aparência cotidiana um outro mundo, encantado ou infernal. É como se o conto fantástico, mais que qualquer outro gênero narrativo, pretendesse 'dar a ver', concretizando-se numa sequência de imagens e confiando sua força de comunicação ao poder de suscitar 'figuras'. O que conta não é tanto a mestria na manipulação da palavra ou na busca de um pensamento abstrato, mas a evidência de uma cena complexa e insólita". De fato, parece ser essa a estratégia narrativa de A noiva da casa azul, tanto na construção de seu desfecho sobrenatural como na elaboração do espaço e de sua atmosfera. Ver em: CALVINO, Italo. Introdução. In: CALVINO, Italo (org.). Contos fantásticos do século XIX - O fantástico visionário e o fantástico cotidiano. Trad. DIAS, Maurício Santana, São Paulo: Companhia das Letras, 2011, pg. 13.

${ }^{29}$ CESERANI, Remo. O Fantástico. Trad. TRIPADALLI, Nilton Cezar. Curitiba: Editora UFPR, Londrina: EDUEL, 2006, pg. 84. 
Entretanto, os detalhes da realidade de Juparassu e de seus arredores, desde a renovação e a modernização dos trilhos de trem à epidemia de febre amarela que devastou a cidade, contribuem para a verossimilhança do substrato realista do conto muriliano - isso, sim, um procedimento constante do autor - que será tomado pelos fatos insólitos. De fato, a metamorfose dos espaços e o deslocamento da cidade ao campo, ou vice-versa, já bastam para fazer despontar o sobrenatural em seus contos, como explica Hermenegildo Bastos:

\begin{abstract}
O mundo das pequenas cidades do interior vê-se invadido por novas assombrações. O universo das fábulas e das assombrações. O universo das fábulas e assombrações do anedotário popular (sempre hiperbólico) é atualizado por um outro que, ao contrário do primeiro, nada tem de ingênuo ou lírico [...]. As etapas de modernização sucedemse e atropelam-se, com a mais recente sepultando a mais antiga. O que foi moderno já não é. No entanto, fica sempre alguma coisa que se recusa a desaparecer e se deposita nas casas, nas ruas, nas cidades, nas pessoas, como ruínas que ainda estão de pé, e assombram. O movimento é tão rápido que, como num filme de ficção cientifica, também a última etapa já foi engolida pela voracidade do tempo, e mesmo o futuro envelheceu. As ruínas estão no presente, são o presente, como em "A noiva da casa azul". 30
\end{abstract}

Segundo Bastos, portanto, a solidez do espaço da tradição oral, das histórias supersticiosas e das lendas aterrorizantes não surge senão como ruína. De resto, o que desponta diante dos personagens e do leitor são fantasmas desse tempo ultrapassado e substituído pelo mundo da razão técnica. O crítico aponta ainda como as velhas histórias que organizavam e davam sentido ao espaço arcaico das tradições do homem rural, quando assomam na narrativa de Rubião, colocam-se de maneira perversa: "Em Murilo, se o mundo ingênuo dos causos reaparece é, entretanto, em forma diabólica. E tanto que quase não deixa rastros no hermetismo fantástico. A linguagem, em vez de dar vida às coisas, as destrói” ${ }^{31}$. Sendo assim, a nostalgia dos personagens em relação ao mundo do campo, pulverizado pelas máquinas e pela burocracia das cidades, sempre assume sua face mais dolorosa. Não por acaso, o protagonista de $A$ noiva da casa azul perde o equilíbrio e encerra o conto desvairado.

Há, para isso, uma explicação que, ainda segundo Bastos, encontra-se na maneira com que o escritor mineiro desenvolveu os eventos sobrenaturais dentro de seus contos. Para o crítico, Rubião filiou-se muita mais à literatura fantástica do século XIX - em seu desencanto em relação à modernidade e por sua maneira crítica e pessimista de elaborar suas narrativas do que ao entusiasmo com a realidade extraordinária latino-americana que daria força, algumas décadas depois, ao realismo maravilhoso: “A sua peculiaridade [de Murilo Rubião] está em ter optado pelo fantástico e não pelo realismo maravilhoso. Em vez do tom épico (e mítico-

\footnotetext{
${ }^{30}$ BASTOS, Hermenegildo José. Literatura e colonialismo - Rotas de navegação e comércio no fantástico de Murilo Rubião. Brasília: Editora Universidade de Brasília; Plano Editora: Oficina Editorial do Instituto de LetrasUnB, 2001, pp. 87-88.

${ }^{31}$ Idem, ibidem. pg. 88.
} 
místico), o tom de aporia e derrota (como em Rulfo)"32. Encarados dessa maneira, os contos do autor teriam levado ao extremo as premissas já encontradas na literatura fantástica do Novecentos. Porém, ao invés do homem burguês ser apenas confrontado com aquilo que ficou sufocado pelo racionalismo moderno, o personagem muriliano precisa lutar contra os fantasmas do passado e contra as perversidades da burocracia técnica das cidades.

\section{Obra de muitos espaços (parte II): Murilo Rubião urbano}

Quando o caminho inverso de A noiva da casa azul é realizado, contudo, e o protagonista dirigese do interior rural ao centro urbano - como acontece, por exemplo, no conto A fila - o “extremo" do insólito da literatura fantástica vem à cena, deixa de lado os fantasmas e as casas assombradas e esbarra com a perversidade do funcionamento das cidades. Como Bastos ressalta, a literatura fantástica do século XX não precisa mais recorrer aos mesmos artifícios sobrenaturais dos seus antecessores do XIX, pois a própria realidade insólita do homem citadino já explicita essa crise. Com isso, ao espaço de repartições públicas e corredores labirínticos sucedem os campos abandonados e as construções arruinadas. Tal metamorfose do espaço não muda, no entanto, o desespero dos personagens que o percorrem. Se o noivo de Dalila perde a razão ao deparar-se com as reminiscências do seu passado, o protagonista de A fila perde a própria identidade ao ver-se presa das armadilhas da cidade.

À vista disso, percebemos que os contos urbanos de Murilo Rubião se aproximam mais da atmosfera kafkiana do que dos contos tradicionais da literatura fantástica. O ensaio de Walter Benjamin sobre Franz Kafka, escrito em razão dos 10 anos de sua morte, precisa o cenário de sua literatura de uma maneira que poderia ser aplicada a alguns contos de Rubião. O filósofo o define como o "mundo das chancelarias e dos arquivos, das salas mofadas, escuras e decadentes [...]"33. Delineação fartamente explorada nos estudos sobre o escritor, o universo burocrático dos escritórios e das instituições públicas tornou-se um chavão que alcançou, inclusive, a linguagem coloquial, em que o termo "kafkiano" passou a designar os constrangimentos do homem perante os códigos e as leis sociais, em situações que beiram o absurdo ${ }^{34}$, o que incitou, por sua vez, a percepção mais difundida de Kafka como um escritor do insólito, do fantástico.

\footnotetext{
${ }^{32}$ Idem, ibidem. pg. 89.

${ }^{33}$ BENJAMIN, Walter. Franz Kafka - a propósito do décimo aniversário de sua morte. In: Magia e técnica, arte e política: ensaios sobre literatura e história da cultura - Obras escolhidas vol. 1. Tradução: ROUANET, Sergio Paulo. São Paulo: Brasiliense, 1994, pg. 138.

${ }^{34}$ Milan Kundera problematiza justamente as definições que o termo "kafkiano" pode ter nos variados contextos sociais e históricos. O escritor mostra, por exemplo, como esse termo tinha um significado bastante diferente na então Tchecoslováquia do que ele encontrou na França. Ou seja, em cada lado da Cortina de Ferro, a obra de Kafka
} 
Isso se deve, em grande parte, ao sucesso e à popularização da saga de Joseph K. no romance $O$ processo - em que assistimos à sua acusação, sua condenação e sua posterior execução sem que saibamos, assim como o próprio herói da história, os motivos que o levaram a esse desfecho - mas também graças ao outro romance fragmentário de Kafka: O castelo. Nesta história, o agrimensor K., chamado para trabalhar num castelo desconhecido, jamais consegue penetrar as instalações principais da construção, tampouco descobrir as razões de ter sido chamado àquele lugar. Em ambas as histórias, os lugares que seduzem e manipulam os protagonistas são tão inacessíveis que eles chegam a duvidar de sua veracidade e do seu poder, mesmo submissos, a todo momento, à sua presença. $\mathrm{O}$ narrador de $O$ castelo, por exemplo, colado às impressões de K., descreve a fortificação como "uma cidadezinha miserável, um aglomerado de casas de vila" ${ }^{\text {, }}$, enquanto Joseph K., ao chegar na rua do tribunal onde tramita seu processo, impressiona-se com a decadência da via que "tinha dos dois lados prédios quase uniformes, altos, cinzentos, de aluguel, habitados por gente pobre" 36 .

Com efeito, a abordagem literária do aparelho burocrático e do espaço das instituições segue a mesma linha kafkiana na prosa de Murilo Rubião, isso desde sua primeira publicação. Já em O ex-mágico da Taberna Minhota, deparamo-nos com as memórias de um homem que, para se ver livre dos truques de mágica involuntários e nada ilusórios que o impossibilitavam de levar uma vida ordinária, toma a decisão de entrar no serviço público a fim de esperar pela morte. Em outros contos, os espaços onde a trama se desenrola são tão atravancados e incontroláveis que não há qualquer possibilidade de ação por parte dos personagens, como em O bloqueio.

Mas é no conto A fila, como já apontamos anteriormente, que essa temática será explorada de maneira mais densa. Nele, o narrador em $3^{\mathrm{a}}$ pessoa (mais uma semelhança com Kafka) apresenta-nos Pererico, um homem que, vindo do interior, chega à cidade grande incumbido de transmitir uma mensagem secreta para o gerente da Companhia. Sem qualquer informação sobre a biografia do herói, sobre o conteúdo da mensagem ou sobre o caráter organizacional da instituição, alcançamos apenas a superfície dos acontecimentos. Pererico, sujeito arrogante e hostil, vê-se incapaz de repassar a mensagem que lhe havia sido confidenciada ao esbarrar em protocolos incompreensíveis. Essas regras, sempre ditadas por

\footnotetext{
era sentida e interpretada de uma maneira. Se os tchecos enxergavam Kafka como um escritor que denunciou o cotidiano burocrático e a opressão dos regimes totalitários, os franceses compartilhavam a visão mais popular, de cuja difusão eles próprios foram protagonistas, do termo "kafkiano" como designador de situações incompreensíveis e absurdas. Ver em: KUNDERA, Milan. A arte do romance. Tradução: FONSECA, Teresa Bulhões Carvalho da. São Paulo: Companhia das Letras, 2009.

${ }^{35}$ KAFKA, Franz. O castelo. Trad. CARONE, Modesto. São Paulo: Companhia das Letras, 2006, pg. 18.

36 _. O processo. Trad. CARONE, Modesto. São Paulo: Companhia das Letras, 2000, pg. 48.
} 
Damião - um senhor negro que Pererico julga ser o porteiro do prédio e que desperta sua ira e seus preconceitos -, revelam-se intransponíveis. As senhas distribuídas àqueles que aguardavam na fila seguiam, a cada dia, uma nova lógica e uma nova numeração, e de nada valia a Pererico chegar com antecedência ou até mesmo pernoitar no prédio da Companhia. Desta, o narrador limita-se a revelar sua presença numa fábrica que, incoerentemente, se encontra num prédio simples, amplo e cheio de corredores.

Degradando-se ao longo da narrativa ao ser consumido pela culpa, vendo seu dinheiro e sua dignidade escaparem-lhe e tendo como único consolo o afeto da prostituta Galimene, o protagonista volta arruinado para o interior sem ter cumprido sua missão, por conta da morte do gerente - de quem ele nunca conseguiu se aproximar:

Dali para frente recusaria as senhas, distanciava-se da fila, a vagar pelo pátio, aferrado à esperança de encontrar o gerente saindo do escritório ou andando pelas ruas, se bem que ignorasse o seu aspecto físico e o roteiro de seus hábitos. Colocava-se em lugares estratégicos, por onde o homem visado poderia passar; investigava as saídas em diferentes horários, inclusive experimentando ficar noites a fio em frente ou nos fundos do edifício da Companhia, e jamais o encontrou. ${ }^{37}$

Desse modo, tanto a Companhia do conto A fila como o Tribunal de $O$ processo, ambos singularizados e personificados pela letra maiúscula inicial, comportam-se de maneira axial nas duas narrativas, mobilizando todos seus componentes, mesmo quando eles não estão dentro de seus espaços físicos. Tudo parece girar em torno de seus centros gravitacionais, ainda que o leitor, assim como os protagonistas, não tenha acesso às características elementares das duas entidades, como suas funções sociais e suas escalas hierárquicas. Devido a essa onipresença asfixiante, nada parece ser capaz de realizar um movimento e ter êxito em penetrá-las, nem mesmo seus funcionários.

No entanto, como já ressaltamos anteriormente, a tirania desses espaços contrasta com a sua aparente debilidade e a falta de detalhamento em suas descrições, o que já era um expediente comum desde a literatura fantástica do século XIX. O crítico Filipe Furtado afirma que a visão oblíqua dos espaços dessas narrativas - tanto a partir dos personagens, como a partir do leitor - garante a verossimilhança insólita do gênero, pois "enquanto um discurso que se pretende "realista" pode usar com vantagem a descrição do espaço até à saciedade, o discurso fantástico deverá evitá-la como um perigo sempre impudente", além disso, "se o emprego intensivo da descrição [...] tivesse lugar na narrativa fantástica, poderia bem levar a que a ocorrência sobrenatural fosse subestimada" ${ }^{38}$.

\footnotetext{
${ }^{37}$ RUBIÃO, Murilo. A fila. In: Murilo Rubião: obra completa. Op. cit. pg. 85.

${ }^{38}$ FURTADO, Filipe. A construção do fantástico na narrativa. Lisboa: Livros Horizonte, 1980, pg. 120.
} 
Nesses espaços desintegrados, onde cada pedaço revelado da Companhia e do Tribunal não parece se conectar com o outro - ainda que se submetam à centralidade das duas entidades - nem os personagens nem o leitor conseguem vislumbrar uma entrada ou uma saída. Rodeados por inúmeros funcionários, repartições, filas, leis, regras, impedimentos, formalidades e tipos que, embora desejem ajudar nesse enfrentamento, apenas atrapalham, faz-se impossível que Joseph K. consiga ser absolvido e que Pererico entregue sua missiva. Em sua breve análise sobre os contos A construção da Muralha da China e Uma mensagem imperial, ambos de Franz Kafka, Antonio Candido comenta a fragmentação presente nos textos:

O que deve ser destacado com particular atenção é a própria natureza fragmentária da empresa, parece que pensada desde o início para não acabar mesmo. [...] Tanto assim que o imperador não sabe de nada, não pode nada, e nem chega a ter existência certa, pois o afastamento social e espacial entre ele e o povo é tamanho, que este pode pensar que um dado imperador está reinando, e no entanto ele já morreu e se trata de outro. Mesmo quanto às dinastias não há certeza. A prova palpável desta incomunicabilidade entre o poder aparente e o povo é a impossibilidade de transmitir a mensagem que o imperador moribundo destina a cada súdito: os mensageiros não conseguem sequer deixar o palácio, e se saíssem não poderiam ultrapassar os limites da Cidade Imperial. ${ }^{39}$

Assim como a monumentalidade das muralhas e das fortificações do Império Chinês, que limita sua própria conclusão e a comunicação entre seus extremos, a Companhia e o Tribunal também são onipresentes - apesar da falta de limites concretos definidos -, cercando todos os espaços com suas paredes invisíveis. Embora situadas no subúrbio de duas grandes cidades, elas alcançam Joseph K. e Pererico em todas as esferas de suas vidas, mesmo quando distantes. Essa influência se dá de maneira paradoxal para os dois protagonistas, incapazes tanto de infiltrarem-se no seu centro quanto de se desvencilharem de suas mãos.

A ausência de relações entre os personagens, que parecem vagar pelas salas e pelos corredores da máquina burocrática como figuras sem nome e sem atributos, caracterizadas apenas por suas funções ou por suas profissões, resulta num contato sempre violento quando se chocam. A violência - lado avesso da comunicação - surge não só na agressão física e verbal de Pererico contra Damião, ou nos desentendimentos constantes de Joseph K. com os membros do Tribunal, mas também na degradação imposta a ambos os protagonistas. ${ }^{40}$

\footnotetext{
${ }^{39}$ CANDIDO, Antonio. Quatro esperas, Segunda: na muralha. In: O discurso e a cidade. Rio de Janeiro: Academia Brasileira de Letras, 2010, pp. 143-144.

${ }^{40}$ Mesmo em suas relações com os personagens femininos, como Galimene em A fila e Leni em $O$ processo, não há satisfação. Movidas por piedade, conhecendo a fatalidade que espera tanto Pererico quanto Joseph K., a compaixão das duas mulheres pelos heróis arruinados pode apenas estabelecer um relacionamento desigual condenado à falência, no qual não se pode estabelecer um vínculo. Günther Anders, ao analisar o papel das mulheres na obra de Kafka, relaciona a compaixão feminina à erotização do evento da comunhão operada ao longo do século XIX. O amor seria o único valor salvo com a decadência econômica e religiosa dos Oitocentos, tornandose símbolo de redenção no começo do século XX. Dessa forma, em Kafka a mulher seria "a única fenda na muralha que separa o estranho do mundo". Ver em: ANDERS, Günther. Kafka: pró e contra - os autos do processo. Tradução de Modesto Carone. São Paulo: Perspectiva, 1993, pp. 34-37.
} 
Como analisa Günther Anders a propósito do herói kafkiano, este vive num estado constante de assombramento diante do mundo, pois, devido à sua condição de desterrado, ele não consegue distinguir os acontecimentos "habituais" dos "não habituais". Por causa de sua cruzada quixotesca através de um mundo que lhe é incompreensível e cujos objetivos, portanto, lhe são inalcançáveis, o herói kafkiano está condenado ao embate violento com a realidade ao seu redor e com os agentes que promovem sua veracidade e seu sentido. Consequentemente, desse confronto nasce a violência dos eventos narrados e da própria narrativa. Ora, a saga de Pererico na cidade grande parece responder com exatidão a esses requisitos e se aproxima, mais uma vez, da condição dos protagonistas das histórias kafkianas, para quem “o estranho, em suas vivências, não é que tanta coisa estranha aconteça, mas que nada do que acontece, mesmo a coisa mais óbvia, seja óbvia; que não haja nada que ele espere, nada com que possa contar. Numa tal situação, é compreensível que tudo seja assustador"41.

Ao mesmo tempo vítima de um poder forte e centralizador e de uma praxe social que foge à sua compreensão, Pererico e os heróis kafkianos permanecem constrangidos à condição de estrangeiros. Isso se deve ao fato de os costumes sociais e o centro administrativo relatados em A fila e nos romances kafkianos serem a mesma coisa dentro de seus universos. Ainda segundo Anders, “a imagem da máquina administrativa inescrutável [...] não representa apenas o retrato da sociedade ou da economia superorganizada: é, antes, a imagem dos hábitos e costumes, tal como a vê o forasteiro" ${ }^{42}$. Além disso, a distância entre o coração desses espaços e sua periferia é tamanha que - conforme a citação de Antonio Candido - não sobram senão alguns vestígios de esclarecimento e muitas dúvidas para os recém-chegados.

Seja pelo deslocamento da cidade em direção ao campo, seja pelo caminho inverso, o herói muriliano sempre se condena ao banimento ensaiando essas mudanças. Quando ele retorna ao interior, por exemplo, esse espaço já se lhe afigura irreconhecível e metamorfoseado em ruínas - assim como as lembranças de seu passado. Ao se direcionar à cidade, contudo, os códigos locais surgem-lhe indecifráveis e, ao mesmo tempo, desafiadores - o que resulta em sua queda. Em comum, os dois heróis dos contos analisados - e daqueles que seguem o mesmo roteiro - não aparentam ter razões suficientes para passar por todas essas provações, uma vez que os motivos que os levam às suas missões são ambíguos e, possivelmente, mentirosos. Retomando Anders, “os heróis de Kafka [e podemos acrescentar, neste caso, alguns heróis de

\footnotetext{
${ }^{41}$ Idem, ibidem. pg. 30.

${ }^{42}$ Idem, ibidem. pg. 31
} 
Rubião] não respondem a perguntas não formuladas, como Dom Quixote, mas, ao revés, perguntam sempre e nunca recebem uma resposta"43.

Além da semelhança na psicologia dos protagonistas e em suas trajetórias, outro traço muriliano que une os dois contos (A fila e A noiva da casa azul), malgrado suas diferenças, pode ser verificado, portanto, na importância que os espaços ficcionais assumem na condução da narrativa - nesses e na maioria dos contos de Rubião. Conforme nossa discussão apontou em alguns momentos, a presença da cidade, por exemplo, será quase um condicionante às características kafkianas de seu texto. Por outro lado, a presença de outros espaços - sobretudo o campo - garantirá ora lugares devastados pelo esquecimento, ora ambientes de atmosfera onírica (como em A Casa do Girassol Vermelho e em Bruma), ambos mais próximos de suas influências das narrativas orais. Há ainda os contos que se localizam no meio-termo entre a cidade e o campo e carregam características das duas regiões (como a pequena cidade de $O$ homem do boné cinzento).

Apesar de essas serem as principais molduras dos contos do escritor, isso não significa que os espaços estejam sempre fixos. Pelo contrário, muitas vezes eles são o fator de movimento da narrativa, impulsionam os acontecimentos da trama e funcionam como uma espécie de extensão dos dramas internos dos personagens (como nos contos $O$ edifício e A armadilha) ${ }^{44}$. Mesmo nos contos recém-analisados, o espaço que dá o tom das intrigas vividas por Pererico e pelo noivo de Dalila e que se responsabiliza pelo desfecho trágico dos dois. Dessa maneira, os espaços dos contos de Rubião estão sempre se metamorfoseando em íntimo acordo com as peripécias dos protagonistas, seja na cidade que ganha características maquinais, seja no campo situado entre a ruína e o sonho.

Embora as semelhanças entre alguns contos de Murilo Rubião e a obra de Kafka não se limitem aos pontos citados anteriormente (e mais aproximações entre os dois autores serão apresentadas no segundo capítulo), cumpre-nos assinalar, mais uma vez, que há outros tipos de

\footnotetext{
${ }^{43}$ Idem, ibidem. pg. 30.

44 A relevância da construção do espaço literário e a perda de limites entre essa dimensão e a interioridade dos personagens já chama a atenção de Osman Lins em seu estudo sobre o tema. Em primeiro lugar, Lins admite a essencialidade do espaço para o andamento da narrativa fantástica, considerado por ele como "elemento dominante". Como exemplo, o crítico cita as aventuras de Alice, os contos de José J. Veiga e o Castelo de Kafka. Posteriormente, ao comentar as relações estabelecidas entre personagens e espaço na literatura de seu século tanto interiores quanto exteriores -, Lins assinala a dificuldade de estudar essa dimensão da obra literária, pois tudo nela parece convergir à espacialidade: "Excetuando-se os casos, hoje pouco habituais, de intromissão do narrador impessoal mediante o discurso abstrato, tudo na ficção sugere a existência do espaço - e mesmo a reflexão, oriunda de uma presença sem nome, evoca o espaço onde a proferem e exige um mundo no qual cobra sentido. Temos, pois, para entender o espaço na obra de ficção, que desfigurá-lo um pouco, isolando-o dentro de limites arbitrários". Ver em: LINS, Osman. Lima Barreto e o espaço romanesco. São Paulo: Ática, 1976, pp. 6669.
} 
cenários na ficção muriliana, que vão além do campo fantasmagórico de A noiva da casa azul e a asfixiante urbanidade de $A$ fila. Em todo caso, eles costumam servir como pano de fundo para as histórias mais oníricas - e líricas - do autor.

\section{Obra de muitos espaços (parte III): Murilo Rubião e o realismo maravilhoso}

O conto Bruma (a estrela vermelha), por exemplo, equilibra-se nesse limiar dos espaços híbridos de Murilo Rubião. A história dos irmãos Godofredo (Godô) e Og e da disputa dos dois pela atenção de Bruma - apelido de sua meia irmã Dora - desenrola-se num espaço que aparenta ser a periferia rural de alguma cidade pequena. $\mathrm{O}$ narrador em primeira pessoa, Godô - que conta eventos de seu passado, quando ele e seu irmão ainda eram jovens - rememora sua irritação com a relação afetuosa de Og com Bruma. Estes costumavam passar o tempo livre das manhãs andando pelas trilhas da região, para que o irmão pudesse observar certos astros que apareciam no céu claro, principalmente uma estrela muito vermelha. Godô, convicto da loucura de Og e enciumado com a atenção que Bruma lhe despendia, trata o irmão de maneira violenta e decide se livrar dele. Para isso, dirige-se à cidade com Dora e Og para levá-lo a uma consulta com um psiquiatra chamado Dr. Sacavém - que demonstra um sincero interesse pelas visões do irmão. Mesmo apaixonado pela irmã de criação, arrependido da maneira como tratava seu irmão e aconselhado pelo médico a buscar tratamento - pois era ele, segundo o Dr. Sacavém, quem necessitava de ajuda - Godô abandona os dois na cidade e volta sozinho à fazenda, onde passa a morar somente com a mãe.

Consternado pela separação de seu irmão e, sobretudo, pela saudade e pela paixão que sente por Dora, Godô resolve voltar à cidade, algum tempo depois, a fim de procurá-los. No entanto, no lugar em que se situava o prédio do psiquiatra já não há mais nada. Por fim, chorando desesperado no lote onde deveria se encontrar o consultório médico, Godofredo consegue enxergar, subitamente, a estrela vermelha sobre a qual Og tanto falava:

\footnotetext{
Sentia-me, no entanto, bastante confuso, pois não encontrava o edifício procurado. No lugar em que ele deveria erguer-se havia um lote vago. Parei um instante, a fim de orientar-me. Em vão. Não atinava com outro percurso. A rua era mesmo aquela. Restava informar-me, mas as pessoas a quem recorri não sabiam da existência de prédios com dez andares mencionados por mim. O maior da cidade possuía dois pavimentos. Nem ao menos, entre os cinco médicos do lugar, conheciam um com o nome de Sacavém. Percorri novamente o lugarejo, fiz outras perguntas. Inútil e angustiante busca. Voltei ao lote. Sentei-me na grama e me abandonei ao desespero, sabendo que jamais reencontraria Bruma. Sobre os braços, chorei longamente. Ao me levantar, prestes a findar a tarde, estendia-se na minha frente uma estrela vermelha. Pouco a pouco, ela se desdobrou em cores. Todas as cores. ${ }^{45}$
}

\footnotetext{
${ }^{45}$ RUBIÃO, Murilo. Bruma (a estrela vermelha). In: Murilo Rubião: obra completa. Op. cit. pg. 128.
} 
Este desfecho, tal qual o fim de A noiva da casa azul, põe em relevo uma possibilidade de leitura que desestabiliza toda a fala do narrador até então - neste caso, o relacionamento de Godofredo com seu irmão e com Bruma - e que desperta mais dúvidas do que respostas no leitor. O desaparecimento dos dois, a ausência do prédio onde, supostamente, estaria o consultório do Dr. Sacavém, o desconhecimento deste homem por parte dos moradores da cidade, o descontrole de Godô ao andar pelas ruas labirínticas da cidade, tudo isso concorre para desconfiarmos de sua sanidade mental. Outros fatores, anteriores ao trecho citado, já davam pistas da presumível condição do narrador. Há, por exemplo, a insistência de Dora em afirmar que Og não está louco e em repreender a postura injusta e violenta de Godô. Em especial, a consulta com o psiquiatra representa a primeira ruptura com a maneira que a história vinha se desenhando até então - as angústias de três adolescentes do interior - e indica, explicitamente, algo de errado no comportamento do narrador. Dr. Sacavém recomenda-lhe tratamento e mostra-se pouco otimista em relação ao seu caso: "Examinou-me atentamente e balançou, desalentado, a cabeça" ${ }^{\text {. }}$.

O diagnóstico parece ser definitivo e isso motiva, justamente, o retorno precipitado do protagonista para casa. $\mathrm{O}$ desfecho, contudo, aumenta ainda mais as incertezas da trama, pois deixa em dúvida a própria existência de Og e de Bruma, cujo desaparecimento confirma a suspeita. Todavia, ao contrário de A noiva da casa azul, em que o tempo presente dos últimos parágrafos coloca a situação do narrador como um possível delírio, o tempo passado no final de Bruma indica uma condição oposta. O evento sobrenatural que arrebata Godô já aparece apaziguado pela distância do tempo e, mais do que isso, parece ter sido plenamente aceito por ele. Logo, o leitor também se permite aceitar o acontecimento insólito e adere à fantasia. Com essa mudança de tom, a narrativa deixa de contrapesar a realidade empírica e as passagens extraordinárias para fincar-se no campo do maravilhoso. Por um lado, os astros luminosos da manhã de fato existem e finalmente podem ser vistos pelo protagonista, que não esboça surpresa diante da aparição e de sua rememoração. Por outro lado, o paradeiro de Dora/Bruma e de Og e a existência real ou imaginária do consultório psiquiátrico permanecem uma questão insolúvel e deixam o conto em aberto. No entanto, o que não deixa mais dúvidas é a aceitação por parte do narrador dos eventos insólitos.

Uma vez que não há mais hesitação, já não há mais literatura fantástica nos moldes tradicionais. Hermenegildo Bastos, em outro texto sobre a obra de Murilo Rubião, salienta a fragilidade do gênero fantástico, que não funciona senão como um agrupamento de convenções

\footnotetext{
${ }^{46}$ Idem, ibidem. pg. 127.
} 
partilhadas pelo escritor e pelo autor para se distanciar da trama realista, embora continuem aquém dos limites do registro maravilhoso. Se uma dessas convenções naufraga durante uma história, portanto, todo o efeito fantástico é perdido e já não se pode considerar tal narrativa pertencente ao conjunto: “O fantástico é o gênero mais limitado por normas, mais do que o realismo no sentido restrito de estilo de época. Os traços que o caracterizam são obrigatórios, não podendo, pois, faltar" ${ }^{\prime 4}$.

De fato, embora alguns contos de Rubião, ainda segundo Bastos, se encaixem nessas estreitas balizas do gênero fantástico tradicional (como é o caso de A noiva da casa azul), grande parte deles está em outro lugar, que o crítico vai simplesmente nomear de "literatura insólita". Para justificar sua escolha, Bastos faz uma comparação entre as leis de causa e efeito da literatura realista e da literatura insólita e suas consequências para os personagens:

\begin{abstract}
Em certo sentido, as redes de causa e efeito são mais fortes no fantástico do que no realismo. Enquanto este se caracteriza pela luta do personagem contra seu destino, no outro o personagem vive sempre uma situação de aporia, no mais das vezes absoluta. Na camada superficial, a narrativa insólita quebra a rede de causa e efeito, mas, na camada mais profunda, os personagens são marionetes (forçoso é lembrar aqui " $\mathrm{O}$ homem da areia”, de Hoffmann). Quebrar as redes de causa e efeito seria estabelecer o reino da liberdade, mas no insólito não há liberdade: forças inimagináveis, incontroláveis reduzem os personagens a meros objetos e joguetes. [...] A possibilidade de escolha é um traço do realismo, e os personagens lutam por ela. No insólito, a ausência de escolha pode levar ao conformismo. ${ }^{48}$
\end{abstract}

Bastos, dessa maneira, enxerga tanto na literatura fantástica do século XIX quanto na literatura insólita do XX a mesma impotência dos personagens diante da trama sobrenatural, fator determinante para moldar suas personalidades marcadas pela insatisfação e pelas metamorfoses (tópicos que serão aprofundado nos próximos capítulos). Na prática, alteram-se tão-somente as estratégias de construção dos eventos extraordinários, que do jogo sugestivo de “dar a ver" alguma coisa inquietante ${ }^{49}$ passa a explicitar um mundo incompreensível ao leitor e aos personagens. Como consequência disso, as leis do mundo ficcional deixam de se sustentar no confronto entre real e insólito para abraçar as regras intransigentes deste último. O crítico, no entanto, enxerga a aceitação dos personagens a partir de uma perspectiva negativa, pela qual nunca pode haver satisfação com a descoberta das novas leis. Mas como explicar, por exemplo, a experiência onírica - até mesmo lírica - de Godô ao se deparar com a estrela vermelha que se desdobra em todas as cores? Em Bruma, testemunhamos uma mudança de valoração do fato sobrenatural em suas últimas frases, quando aquilo que parecia ser sinal de loucura transformase em experiência positiva. $\mathrm{O}$ espaço hostil e labiríntico da cidade suaviza-se com sua nova

\footnotetext{
${ }^{47}$ BASTOS, Hermenegildo. Do insólito ao espectral em “Ofélia, meu cachimbo e o mar”. In: GARCÍA, Flavio, BATALHA, Maria Cristina (org.). Op. cit. pg. 98.

${ }^{48}$ Idem, ibidem. pg. 99.

${ }^{49}$ Ver a nota de rodapé 28 sobre Calvino.
} 
coloração. Não há apenas fracasso, portanto, na adaptação do herói muriliano às armadilhas do insólito e, com efeito, o desespero diante do sobrenatural pode transformar-se em júbilo.

Seria isso, portanto, um sinal que confirma a suposição de que Murilo Rubião já antevia certos aspectos do gênero chamado "realismo maravilhoso", conforme convencionado pela crítica literária? De fato, como observamos na primeira parte deste capítulo, houve uma confluência de interesses que fez com que a obra de Rubião fosse de fato valorizada durante a década de 70, pouco depois dos escritores latino-americanos ganharem projeção internacional por divulgarem as novidades que despontavam em parte do continente - majoritariamente na porção de língua espanhola.

Esse já seria um dado relevante, portanto, para considerarmos a aproximação necessária, ainda mais quando são levadas em conta as dificuldades da crítica literária em teorizar a propósito das diferenças e das semelhanças que unem e afastam a literatura fantástica do gênero mais recente. Irlemar Chiampi, autora de um dos estudos mais relevantes acerca do realismo maravilhoso, aponta alguns desses percalços enfrentados pelos críticos:

É certo também que o fantástico e o realismo maravilhoso compartilham muitos traços, como a problematização da racionalidade, a crítica implícita à leitura romanesca tradicional, o jogo verbal para obter a credibilidade do leitor e, razão de frequentes confusões da crítica literária, compartilham os mesmos motivos servidos pela tradição narrativa e cultural: aparições, demônios, metamorfoses, desarranjos da causalidade, do espaço e do tempo, etc. ${ }^{50}$

Para traçar as diferenças existentes de um registro a outro, Chiampi opta por iniciar seu caminho colocando em pauta a postura dos personagens e a recepção dos leitores como o contraste mais aparente entre os dois. Em tal oposição que coloca num polo o plano empírico e no outro o plano do insólito, o realismo maravilhoso estaria imerso no segundo. O que está em jogo em sua peculiaridade, para a estudiosa, se relaciona mais com a percepção do que com aspectos temáticos ou formais. A reação diante desse mundo deve ser constantemente harmônica e sem sobressaltos, contrariando a hesitação da literatura fantástica e o sentimento de impotência do insólito do século XX: "o realismo maravilhoso desaloja qualquer efeito emotivo de calafrio, medo ou terror sobre o evento insólito. No seu lugar, coloca o encantamento como um efeito discursivo pertinente à interpretação não-antitética dos componentes diegéticos" ${ }^{51}$. Por fim, conclui descrevendo a transição efetuada pelo realismo maravilhoso ao subverter o ponto de vista racional: “o insólito, em óptica racional, deixa de ser o 'outro lado', o desconhecido, para incorporar-se ao real: a maravilha é(está) (n)a realidade.

\footnotetext{
${ }^{50}$ CHIAMPI, Irlemar. O realismo maravilhoso: forma e ideologia no romance hispano-americano. 2. ed. São Paulo, Perspectiva, 2008, pp. 52-53.

${ }^{51}$ Idem, ibidem. pg. 59.
} 
[...] o realismo maravilhoso se qualifica pela relação entre o efeito de encantamento (o discurso) e o relato" $" 52$.

O trabalho dos escritores que contribuíram, cada um à sua maneira, para a consolidação do realismo maravilhoso se dirige sobretudo, ainda segundo Chiampi, à elaboração desse "maravilhoso" que dá nome ao conjunto. A principal dificuldade, portanto, está na apreensão e na descrição de algo que, a princípio, se conserva no campo do inefável. Afinal, como relatar o indizível e construir um espaço mágico sem cair na tradição dos contos de fada ou de outros textos que se relacionam com o mundo mítico/místico?

Em vez de caírem no silêncio, porém, ante as maravilhas e os contrastes do continente latino-americano, Chiampi salienta que a estratégia mais comum utilizada por tais escritores foi a do barroquismo descritivo, ou seja, a do excesso e da multiplicidade de informações e de detalhes. Dessa forma, os narradores do realismo maravilhoso encontram-se sempre diante do indizível e do dilema de como comunicar o incomunicável: “Como denúncia de uma situação narrativa constrangedora, a retórica barroquista quer dizer o indizivel; persegue com a multiplicação (ou distorção) dos significantes o objeto indescritível" ${ }^{\prime 3}$. Esse jogo retórico de buscar a melhor maneira de descrever objetos que parecem inalcançáveis à linguagem fortalece, por sua vez, o conteúdo em constante metamorfose da narrativa. Há, no realismo maravilhoso, a descrição de um mundo vacilante que foge às tentativas de fixação racional do narrador realista - encontrado no romance tradicional do século XIX - e que esbarra em mudanças perenes tanto no descontrole dos espaços e do tempo quanto nas mutações físicas dos personagens. Como apresentamos anteriormente, nas palavras de Hermenegildo Bastos, o universo maravilhoso dessa literatura condiciona-se ao tom mítico do herói épico ${ }^{54}$. O que Chiampi afirma, portanto, com seu conceito de barroquismo descritivo é a tentativa da construção - ou reunião - de uma mitologia latino-americana por parte desses escritores.

Alejo Carpentier, ao comentar o mesmo período da literatura em seu continente, reforça a ideia de uma narrativa cosmogônica, atenta às histórias da tradição oral miscigenada da América Latina e compromissada com o estabelecimento de um panteão mítico que dê conta das diferenças abismais entre os seus vários povos, idiomas e costumes. $\mathrm{O}$ escritor cubano mostra-se inquieto com as possibilidades de criação deixadas de lado pelos ficcionistas desses países, cujas fontes de inspiração ainda em estado bruto são inúmeras: “Acontece que, pela virgindade da paisagem, pela formação, pela ontologia, pela presença fáustica do índio e do

\footnotetext{
52 Idem, ibidem.

${ }^{53}$ Idem, ibidem. pg. 85. Grifos do autor.

${ }^{54}$ Ver a citação da nota de rodapé 30 de Hermenegildo Bastos.
} 
negro, pela revelação que constituiu sua recente descoberta, pelas fecundas mestiçagens que propiciou, a América está longe de ter esgotado seu caudal de mitologias"

Além de aglomerar as inúmeras mitologias do continente e fazer de seus passados um substrato cultural, Carpentier ainda afirma que seus escritores têm por dever um exercício formal em sua ficção - descrever a miscelânea de formas e de figuras das cidades latinoamericanas. Exercício este capaz de transformar o estilo e a técnica literária da região, culminando em sua emancipação do centro de produção artística europeu. As cidades do Velho Mundo se oferecem desembaraçadamente à imaginação e à caneta dos escritores, já funcionam como cenários cinematográficos previsíveis, seja nos grandes bulevares e nos edifícios haussmanianos de Paris, seja nas vielas góticas de Praga. Os escritores latino-americanos, no entanto, não têm isso à mão. Ao saírem do conforto das paisagens naturais de seus países para encarar os enigmas das esfinges urbanas da América Latina, seu estilo arquitetônico que se caracteriza, precisamente, pela falta de um estilo único, pelo não convencional, além das disparidades econômicas e culturais de sua população que criam novos meios de convivência e de segregação, eles são compelidos a revolucionar as formas tradicionais da literatura e a enfrentar o insólito presente em suas vivências. Daí que surgiu, ainda segundo Carpentier, um dos combustíveis responsáveis pelo boom do realismo maravilhoso hispano-americano advogado pelo próprio crítico, fenômeno mundial que colocou a América Latina no mapa literário e chacoalhou o eixo centro-periferia de produção e de recepção $\operatorname{artísticas~}^{56}$.

Reunindo o conceito de descrição barroca de Chiampi com as preocupações manifestas nos textos de Carpentier, a propósito do trabalho com os mitos e com o espaço em transformação da América Latina, logo compreendemos a conexão realizada por certa parte da crítica literária entre a obra de Murilo Rubião e o realismo maravilhoso (detalhada na primeira parte deste capítulo). Com efeito, os contos do autor erguem-se - assim como a dos autores da América Hispânica no período citado - assentados num solo movediço fruto dos choques entre

\footnotetext{
55 CARPENTIER, Alejo. Do real maravilhoso americano. In: A literatura do maravilhoso. Trad. GOLDONI, Rubia Prates e MOLINA, Sérgio. São Paulo: Editora Revista dos Tribunais, Edições Vértice, 1987.

${ }^{56}$ Carpentier usa a metáfora da revelação e da pintura como base do seu raciocínio a respeito das obrigações dos escritores latino-americanos: “[...] Muito poucas das nossas cidades têm sido reveladas até agora - a menos que se creia que uma mera enumeração de exterioridades, de aparências, constitua a revelação de uma cidade. Difícil é revelar algo que não oferece informação livresca preliminar, um arquivo de sensações, de contatos, de admirações epistolares, de imagens e enfoques pessoais [...]. Talvez pela dificuldade da tarefa, preferiram os nossos romancistas, durante anos, pintar montanhas e planícies. Mas pintar montanhas e planícies é mais fácil que revelar uma cidade e estabelecer suas relações possíveis - por afinidades ou por contrastes - com o universal. Por isso é essa a tarefa que se impõe agora ao romancista latino-americano. Por tê-lo compreendido assim é que seus romances começam a circular pelo mundo, enquanto que o nosso romance nativista, tido por clássico nos liceus municipais, nem convence mais as novas gerações, nem tem leitores no lugar de origem - quando os tem no lugar de origem. Mero objeto de uso caseiro". Ver em: Problemática do atual romance latino-americano. In: Op. cit. pg. 50.
} 
diferentes realidades e diferentes espaços. Neles, o leitor se vê diante da sobreposição de cidades e de campos, de homens de um ou de outro espaço fadados à diáspora (não por acaso, palavra-título de um de seus contos) e ao desterro. Neles, também, Rubião trabalha as diferentes tradições culturais da narrativa que se misturaram para dar forma às suas ficções, que retomam as velhas histórias mineiras cheias de assombrações e entidades mágicas (no capítulo 3 veremos, por exemplo, o papel da lenda do lobisomem para o conflito do conto Alfredo).

Entretanto, a abordagem muriliana dos temas e dos procedimentos formais levantados por Carpentier como essenciais aos escritores latino-americanos parece, de fato, não levar dentro de si as mesmas intenções que o ficcionista cubano e seus colegas de pena. Como enxergar no êxtase de Godô um tipo de experiência mítico-coletiva que refletiria, a partir do destino de um homem, a sina de todo um povo? Ou, num cenário mais reduzido, enxergar na trajetória do herói de Bruma as preocupações histórico-sociais concernentes, como aponta Chiampi, à maioria dos escritores do realismo maravilhoso, tais quais os problemas de formação étnica e cultural dos países latino-americanos ${ }^{57}$ Não há, pois, nenhum indício de coletividade em sua paixão por Dora, em seu arrependimento após a injustiça cometida contra seu irmão e em sua redenção final. Não há tampouco aquela literatura épica que "se encontra a cada passo nas vidas de homens que inscreveram datas na história do continente e deixaram sobrenomes que ainda são usados" ${ }^{58}$, conforme afirmou Carpentier a propósito do herói típico do realismo maravilho da América Hispânica. Trata-se, portanto, de uma experiência individual que não se relaciona senão com os conflitos e com as angustias de Godô, apesar do movimento transcendente do final do conto.

À vista disso, a obra de Murilo Rubião parece estar muito mais isolada em si mesma do que a literatura do realismo maravilhoso, em relação a qual parte da crítica considera o escritor mineiro uma espécie de antecessor inesperado. Retomando o que foi anunciado logo no início do capítulo, os contos do escritor mineiro estão tão voltados para si mesmos - como um bloco espesso que apara suas arestas num movimento constante - que pouco de seus conflitos pode

\footnotetext{
${ }^{57}$ Irlemar Chiampi distingue a literatura brasileira e a literatura norte-americana do resto da literatura hispanoamericana por terem se preocupado menos com as questões relacionadas ao papel de suas criações dentro do cenário ocidental. Diferentemente do que aconteceu nas nações de língua castelhana, o Brasil e os Estados Unidos, ainda segundo Chiampi, não desenvolveram suas literaturas tendo como principal preocupação o cotejamento com o que era produzido na Europa, sobretudo na França: “A indagação sobre o que é a América tem sido, sistematicamente, a força propulsora e profundamente vitalista do pensamento hispano-americano. Para esse núcleo ontológico irredutível das teses americanistas converge todo o interesse pela difusão e penetração das ideologias na América Hispânica, posto que a sua História das Ideias assinala um movimento contínuo de produção e modificação das interpretações sobre a realidade continental. Não encontraremos na reflexão norte-americana, nem na brasileira, a mesma veemência, e até obsessão, com que os hispano-americanos têm sentido a necessidade de definir a sua cultura no contexto ocidental". Ver em: CHIAMPI, Irlemar. Op. cit. pg. 96.

${ }^{58}$ CARPENTIER, Alejo. Do real maravilhoso americano. In: Op. cit. pp. 141-142.
} 
ser, direta e incontestavelmente, conectado a um referente externo à própria realidade da narrativa (salvo alguns contos como Ofélia, meu cachimbo e o mar, que faz alusões explícitas ao processo de colonização do Brasil). Se, de um lado, esse dado refuta as comparações entusiastas com o realismo maravilhoso, por outro lado, indica a importância da compreensão crítica da lógica interna do bloco formado pelos contos de Rubião.

Ora, os contos em metamorfose contínua de Rubião estão mais ligados ao seu próprio funcionamento do que alarmados, mesmo que aparentemente, com alguma urgência extraliterária. Como consequência disso, há a necessidade de perscrutarmos a relevância do processo de escrita do autor para a construção desse conjunto, sobretudo por ser um de seus temas mais recorrentes - embora sempre apareça metaforizado - de sua produção literária.

\section{A angústia da criação e os labirintos da reescrita}

O conto Marina, a intangível desenrola-se - como a maioria dos contos de Rubião - a partir da voz de um narrador em primeira pessoa já situada no apaziguamento da voz passada, que conta os eventos insólitos por meio do tom melancólico da rememoração. O protagonista José Ambrósio relata o que lhe ocorreu numa madrugada de muita angústia e de pouca inspiração para escrever, quando passou horas sentindo-se culpado por precisar de uma história para o jornal em que trabalha e não conseguir encontrá-la. Solitário e religioso, José recorre à Bíblia a fim de buscar algum assunto que lhe interesse para uma nova narrativa, "mesmo que fosse a mais caótica e absurda" ${ }^{59}$. Durante todo esse tempo, ele teme uma ameaça que parece rodear sua casa e que pode surgir a qualquer momento do jardim. Tentando se distrair com suas leituras do texto sagrado, José enfim descobre uma história que pode lhe servir como estopim ficcional. Embora a história não tenha, aparentemente, nenhuma relação com as narrativas bíblicas, ele propõe-se a narrar a vida de Marina, a intangível - ou Maria da Conceição - uma mulher que viveu um romance melodramático com um velho soldado.

No entanto, logo que José se convence a começar a criação da história, sua inspiração desaparece e ele nota um visitante misterioso no jardim. A animosidade entre os dois logo se evidencia e, pouco a pouco, o conflito ganha densidade. A estranha visita confessa também sua admiração por Marina e revela a José que, sob encomenda deste, compôs a ela um poema. Tal novidade deixa-o furioso e ao mesmo tempo perturbado, pois não se lembrava de ter pedido qualquer poema para o seu jornal, que nunca aceitava textos líricos. Mesmo a contragosto do

\footnotetext{
${ }^{59}$ RUBIÃO, Murilo. Marina, a intangível. Murilo Rubião: obra completa. Op. cit. pg. 104.
} 
dono da casa, o visitante invade a casa e passa a despedaçar flores no jardim, cujas pétalas seriam a única maneira de escrever um poema para Marina: "Os primeiros cantos são feitos de rosas despetaladas. Lembram o paraíso antes do pecado" ${ }^{60}$. Irritado com a destruição das flores e com a intenção do visitante de achar um girassol para também o destruir, José Ambrósio já estava disposto a partir para a violência quando, repentinamente, se inicia o cortejo de Marina, a intangível, que toma o jardim e a casa do narrador.

O cortejo passou em segundos, e os muros, que antes via na minha frente, transformaram-se num só. Quis correr, para alcançar o andor que levava Marina, porém os papéis, jogados para o ar e espalhados pelo chão, atrapalharam-me. Quando deles me desvencilhei, encontrava-me só no terreiro e nenhum som, nenhum ruído se fazia ouvir. Sabia, contudo, que o poema de Marina estava composto, irremediavelmente composto. Feito de pétalas rasgadas e de sons estúpidos. ${ }^{61}$

Como um lampejo, portanto, o cortejo passa diante do narrador embasbacado, incapaz de alcançar o andor que levava Marina por conta do turbilhão de papéis ao seu redor. A narrativa, que vinha no ritmo lento de uma noite de insônia e de angústia, ganha a velocidade da insólita procissão que durou tão-somente alguns segundos. O longo diálogo entre o narrador e o visitante desconhecido - conduzido por digressões sobre a necessidade de se compor um poema para Marina - cala-se com a profusão de imagens suscitadas pela aparição da tão aguardada fonte de inspiração. O próprio poeta, fonte da irritação do narrador, desaparece com a chegada da musa. Com isso, dá-se início à descrição de sua entrada ruidosa e exuberante. Seu séquito concilia figuras que, aparentemente, não possuem nenhuma relação entre si - padres capuchinhos acompanhados de pistonistas da Filarmônica Flor-de-Lis e de um coral dos homens de caras murchas.

No centro da confusão, surge a imagem excessivamente ornamentada de Marina, que traz "no corpo um vestido de cetim amarfanhado, as barras sujas de lama", e no rosto "os lábios excessivamente pintados, e olheiras artificiais muito negras, feitas a carvão"62. Além disso, Marina levava "na mão direita um girassol" - a flor desejada pelo visitante misterioso - e encarava o narrador "com ternura" 63 . Este, por sua vez, mirava a mulher extasiado, num misto de erotismo e de reverência. A atmosfera onírica desse excerto, cujo caráter insólito já se anunciava com a aparição do visitante anônimo, ganha densidade com a metamorfose espacial da casa do narrador - que se metamorfoseia numa parada militar ou desfile carnavalesco ou cortejo religioso - e com a suspensão do tempo - que passa da regularidade do diálogo para a indecisão de um discurso descritivo-narrativo acelerado e enumerativo que, segundo o narrador,

\footnotetext{
${ }^{60}$ Idem, ibidem. pg. 108

${ }^{61}$ Idem, ibidem. pg. 110.

${ }^{62}$ Idem, ibidem. pg. 108.

${ }^{63}$ Idem, ibidem.
} 
não durou senão por alguns segundos - para voltar, nos últimos parágrafos, à situação inicial da história.

Assim como no conto A noiva da casa azul, o desfecho de Marina, a intangível desestabiliza toda a narrativa precedente. Os recursos formais utilizados, porém, são de outra ordem. Neste conto, em vez de alterar a voz do pretérito para a voz do presente, o narrador decompõe a segurança da ordem espacial - bem solidificada na casa e no jardim - e bagunça a constância temporal que perdurava até o momento da chegada de Marina - embora o discurso acelere, o leitor não consegue aceitar que a quantidade de fatos narrados seja equivalente aos poucos segundos citados pelo narrador ${ }^{64}$. Dessa forma, a descrição do herói do conto, já situada num tempo de enunciação posterior aos eventos da noite do cortejo, dá conta de vários detalhes que, na época em que se passaram os fatos narrados, duraram apenas instantes.

A narrativa retorna, portanto, à indecisão espacial que, assim como nos contos anteriores, define o universo muriliano. Entre o enfado dos lugares reconhecíveis - a casa do jornalista - e a ameaça da instabilidade dos delírios e dos sonhos - o jardim -, o protagonista tateia a descrição de um espaço que já se fragmentou na memória e que se evade da linguagem, como notou Cleber Araújo Cabral a respeito desse tópico:

\begin{abstract}
Assim, as paisagens rurais ou urbanas presentes na obra de Murilo Rubião, antes de serem ambientes determinados e reconhecíveis, dotados de fisionomia precisa, parecem ser sugestões de um espaço indefinido. Neste mundo imaginário e dúbio, no qual a cartografia convencional parece inútil como instrumento de orientação, os fragmentos que divisamos mostram uma paisagem erma, atravessada por um trem (que por vezes não chega ao destino escolhido) que nos conduz a locais estranhamente familiares $-\mathrm{e}$ incertos, tal como nossa percepção da realidade..$^{65}$
\end{abstract}

Do cortejo mágico que escolta Marina surge, como consequência, o poema feito de pétalas - que já vinham sendo despedaçadas pelo poeta antes do desfile - e de sons - o que explica a algazarra dos músicos companheiros da musa. A metamorfose de todos esses

\footnotetext{
${ }^{64}$ Sobre as técnicas narrativas de aceleração ou de refreamento do discurso, Umberto Eco, num dos ensaios dos Seis passeios pelo bosque da ficção, ressalta a importância dos diálogos para estabilizar o tempo narrativo. Além disso, ao confrontar o tempo de leitura com os tempos decorridos dentro dos limites ficcionais - definidos como tempo da história e tempo do discurso -, Eco mostra como essas duas instâncias podem ser diametralmente opostas de acordo com as intenções do escritor: "O tempo da história faz parte do conteúdo da história. Se o texto diz que 'mil anos se passam', o tempo da história são mil anos. Mas, no nível da expressão linguística, ou no nível do discurso ficcional, o tempo de escrever (e ler) a frase é muito curto. É por isso que um tempo do discurso rápido pode exprimir um tempo da história bastante longo. Naturalmente, o contrário também pode acontecer: vimos na conferência anterior [Os bosques de Loisy] que Nerval precisou de doze capítulos para nos contar o que aconteceu em uma noite e um dia; e, depois, em dois capítulos curtos nos contou o que aconteceu no decorrer de meses e anos". Seguindo a conceituação de Eco a propósito do tempo literário, percebemos como Murilo Rubião confunde essas instâncias no seu conto Marina, a intangível, no qual o curto tempo da história dilata-se no tempo do discurso para dar conta do redemoinho de eventos que acontecem simultaneamente após a chegada de Marina. Ver em: ECO, Umberto. Divagando pelo bosque. In: Seis passeios pelos bosques da ficção. Trad. FEIST, Hildegard. São Paulo: Companhia das Letras, 2017.

${ }^{65}$ CABRAL, Cleber Araújo. Lugares de Bruma: coordenadas do imaginário narrativo de Murilo Rubião. Dissertação (Teoria da Literatura e Literatura Comparada), Universidade Federal de Minas Gerais, Belo Horizonte, 2011, pg. 99. Disponível em: http://www.bibliotecadigital.ufmg.br/. Último acesso: 19/06/2018.
} 
elementos origina os versos que cantam Marina. Todavia, essa não era a intenção inicial do narrador, que, a priori, deveria escrever uma narrativa sobre a mesma personagem para o seu jornal. Seria o poema, portanto, uma composição do visitante misterioso? Ora, o narrador ressalta sua solidão ao ver diante de si o texto dedicado à Marina. Fruto da imaginação, fantasma indesejado, duplo ou eu-lírico do protagonista - a identidade do homem não nos é revelada. Sua coautoria do poema, porém, não pode ser questionada. O visitante foi o estopim do desejo poético do narrador e incentivou, por meio do esfacelamento das flores, a chegada de Marina, mas desapareceu assim que ela tomou o jardim.

Ocultando sua real identidade, o conto delineia, contudo, uma firme oposição entre o narrador/jornalista e o desconhecido/poeta. Devido ao impasse entre os deveres de seu trabalho no jornal e sua vontade íntima (reforçada pelo homem anônimo), o poema nasce acompanhado de culpa e de arrependimento, sentimentos explicitados pelo uso do adverbio irremediavelmente e pelos adjetivos rasgadas e estúpidos, que qualificam as pétalas e os sons. A história do poema - que já nasceu da contrição de seu autor - passa a ser narrada pelo próprio poeta (não o anônimo, mas o protagonista), que agora se transformou em narrador de prosa e recomeça a mesma história de uma criação artística, originando, porém, outro tipo de texto.

De um texto que se metamorfoseia em outro texto e assim por diante, esse parece ser o itinerário da obra que será dedicada à Marina. Entretanto, alcançá-la pressupõe, também, abandonar o próprio trabalho que lhe está sendo consagrado. O sentido de tal empreitada mantém-se em suspenso e torna-se ambíguo, uma vez que, neste conto, ela nunca será arrematada. Cabral, por sua vez, vai ainda mais longe e afirma que essa é a condição de toda a obra de Rubião, condenada a preservar-se aberta: "a intenção de multiplicar as possibilidades de sentido, de maneira a excluir qualquer expectativa de leitura conclusiva - procedimento que dá a impressão de que as narrativas prosseguem abertas, irresolutas e indeterminadas, como caminhos que se bifurcam",66.

Os caminhos bifurcados, porém, continuam a se comunicar entre si e a refletir sobre sua própria validade. Criação e narrativa caminham separadas ao mesmo tempo em que exercem influência uma sobre a outra. Esse movimento metalinguístico, que une as metamorfoses da própria história dentro dos limites do conto com as metamorfoses do processo criativo, foi descrito por Flávio Carneiro numa análise sobre a reescrita de Murilo Rubião prefigurada dentro de sua obra. Para o crítico, todos esses aspectos estão ligados à procura de uma escrita cuja transparência idealizada (a forma) transmitiria palavras sem ambiguidades (o conteúdo):

\footnotetext{
${ }^{66}$ Idem, ibidem. pg. 101.
} 
Magia, metamorfose e reescrita se irmanam sob a mesma condição à impossibilidade de alcançar a forma ideal: o homem compreendido, cuja fala é recebida e decodificada pelo outro. Aceitam que discordem de sua palavra, mas que não a considerem incompreensível. Daí tentarem a mudança como instrumento para tentar o inatingível. ${ }^{67}$

Alcançar o inatingível - ou o intangível, no caso do conto analisado -, eis o polo de atração de todos os movimentos da narrativa de Murilo Rubião, para quem, segundo Carneiro, "a contínua metamorfose do texto é a tentativa de se fazer mais compreensível para seu leitor"68. O próprio crítico, no entanto, admite o caráter genérico de tal definição, pois essa seria a preocupação geral da literatura - que está condenada a repetir-se infindamente em cada leitura e ganhar novas significações em cada leitor - e de todos os escritores que se debruçaram sobre a ambiguidade dos signos: "Toda escritura é, por natureza, infinita. Cada leitor opera o milagre simples de despertar a palavra adormecida e torna-la viva pela leitura, interessada ou indiferente, que faz. Sendo único, cada leitor promove uma nova reescritura quando lê pela primeira vez o texto" ${ }^{\prime 69}$.

Não há nisso nenhuma especificidade do conto de Rubião em face da obra dos outros escritores que, cada um a seu modo, também se confrontaram com as armadilhas da linguagem e com a vacilação das palavras. Se o próprio texto multiplica seus sentidos num processo de metalinguagem - em que ele mesmo se inclina sobre a sua feitura e sobre suas dificuldades -, essa tendência cresce exponencialmente cada vez que ele é posto em circulação e ganha uma nova leitura. O que diferencia a obra de Murilo Rubião estaria, portanto, na intensidade com que esse conflito - simbolizado, em Marina, a intangível, nas figuras do narrador jornalista e do poeta desconhecido - desenvolve-se em cada conto e as diferentes maneiras de representálo: "Em Murilo Rubião, isso [o movimento de reescritura] está presente não apenas na quase obsessão pela palavra exata, buscada de um livro a outro, e no diálogo inventivo com outros textos, alheios, como também na própria construção de personagens e enredos"70.

Por fim, se em alguns escritores o conflito com a ambiguidade da linguagem desponta de maneira mais dissimulada, Carneiro reforça a importância desse tópico em Murilo Rubião ao comparar seu processo criativo - como outros críticos antes dele - ao mito de Sísifo ${ }^{71}$. Em

\footnotetext{
${ }^{67}$ CARNEIRO, Flávio. Escrever é escrever de novo: a escrita infinita em Murilo Rubião. In: In: GARCÍA, Flavio, BATALHA, Maria Cristina (org.). Op. cit. pg. 87.

${ }^{68}$ Idem, ibidem.

${ }^{69}$ Idem, ibidem. pg. 88.

${ }^{70}$ Idem, ibidem. pg. 92-93.

${ }^{71}$ Mais especificamente, Flávio Carneiro estabelece relações não apenas entre Murilo Rubião e Sísifo, mas, sobretudo, com o texto de Albert Camus que compara a literatura de seu tempo ao suplício desse personagem mitológico, condenado a empurrar uma pedra montanha acima sabendo que ela cairia assim que eles chegassem ao topo. Assim Camus define a "literatura do absurdo", marcada pelo assombro do indivíduo diante do mundo, ao mesmo tempo em que esse indivíduo-escritor sente-se impulsionado a penetrar nesse mundo e, como consequência, encetar, malograr e reiniciar sua obra. No entanto, há autores que conseguem escapar desse
} 
diversos níveis, a ficção muriliana traz à tona os problemas da reescrita cujo objetivo está sempre além das tentativas do escritor, compelido a recomeçar ainda que ciente do seu fracasso. Além do próprio trabalho de Rubião na reconstrução de seus contos (obsessão que abordamos na primeira parte deste capítulo), seu impasse com a escrita - marcado por um impulso criativo que tende a multiplicações, geralmente metaforizadas pelas metamorfoses, e que não realizam senão algumas mudanças insatisfatórias em seus objetos - ganha contornos narrativos. Dessa forma, consolida-se a passagem da reescrita como um processo exterior à obra para a sua tematização dentro das dimensões ficcionais. Há, na obra de Rubião, contos que trazem explicitamente o tema das construções infinitas - como a Torre de Babel moderna de $O$ edifício e a ponte suspensa de A diáspora - ou do arruinamento daquilo que já estava alicerçado - como a cidadezinha de A noiva da casa azul, o poema que nasce condenado de Marina, a intangível, o consultório de Bruma e o prédio de O bloqueio. Assim, retornando ao texto de Flavio García sobre os discursos fantásticos, destacamos a engenhosidade de Rubião ao confundir os planos de fora e de dentro do universo ficcional. Segundo o crítico, "em um jogo que se pode inferir como metaficional - produto de estratégias de construção do discurso narrativo-literário -, o próprio conto rubiano reflete, no plano da diegese, estratégias discursivas que se vão empregar na estruturação do texto" $" 72$.

Tal qual o poema do conto analisado, que guarda os resquícios da aparição de Marina no meio do jardim - cercada de ruídos ensurdecedores e de paramentos exuberantes -, o conto de Rubião tenta se desvencilhar dos artifícios da linguagem - metaforizado pelos barulhos e pelos ornamentos indesejados - ao mesmo tempo em que se depara com a inevitável artificialidade da ficção. A hesitação da literatura fantástica tradicional, que nasce da vacilação entre uma leitura racional ou uma leitura sobrenatural dos fatos, transforma-se numa hesitação sobre a própria validade e capacidade da linguagem que narra. Ao contrário também, e mais uma vez, dos escritores do realismo maravilhoso - sempre seduzidos pela aproximação do inefável - a prosa de Rubião deseja a expressão ideal na mesma medida que dela deseja se afastar para assim retornar ao silêncio ${ }^{73}$. Assim como o poema dedicado a Marina, seu conto

movimento ao mesmo tempo em que o realizam, ou seja, conquistam a totalidade ao lidar, justamente, com a experiência fragmentária. Camus observa, por exemplo, esse movimento na ficção de Kafka, cuja grandeza e universalidade "decorrem do fato de ele ter sabido representar com tanta amplidão a passagem cotidiana da esperança à angústia e da sensatez desesperada à cegueira involuntária. Sua obra é universal (uma obra realmente absurda não é universal) na medida em que nela aparece o rosto comovente do homem fugindo da humanidade, extraindo de suas contradições razões para acreditar e de seus desesperos fecundos razões para esperar, e chamando de vida sua apavorante aprendizagem da morte". Ver em: CAMUS, Albert. O mito de Sísifo. Trad. ROITMAN, Ari e WATCH, Paulina. 5. ed. Rio de Janeiro: Record, 2008, pg. 156.

${ }^{72}$ GARCÍA, Flavio. Op. cit. p. 21.

${ }^{73} \mathrm{O}$ silêncio se mantém, para o ficcionista, o poeta ou para qualquer artista, apenas como um horizonte utópico. Dada a sua impossibilidade de realização literal dentro da obra de arte, ele fixa sua potencialidade por meio de um 
nunca deixa de carregar em si os sons estúpidos e as pétalas rasgadas e nunca vê a chegada da palavra exata. Relembrando as palavras do visitante misterioso, a linguagem vem como o pecado que sucede as primeiras inspirações da criação literária.

A obra muriliana, portanto, de tal maneira voltada a si mesma como um bloco fechado e tão preocupada em aparar suas arestas, não deixa de se abrir justamente a partir da intenção de se calar. Equilibrada na dualidade expressada pelos pares poema-narrativa, casa-jardim, jornalista-poeta, artifício-realidade, exaltação-frustração, a narrativa muriliana vai se construindo pela tagarelice das transformações insólitas e das histórias bifurcadas e pela busca da palavra ideal, mas sente-se acossada, a todo momento, pela ameaça do silêncio iminente que levaria à sua destruição. Todavia, o vazio que deve ser preenchido é de fato complementado. O que deveria ser mero esteticismo, como as pétalas rasgadas e os sons estúpidos, ganha substância ficcional e de ornamento passa a ser conteúdo narrativo. As metamorfoses despontam desse movimento e, em toda sua diversidade, estarão sempre encalacradas entre a mecanicidade frívola do artifício e a totalidade do símbolo.

campo de força que magnetiza as obras em sua direção. Susan Sontag, num ensaio a propósito desse tema na arte do século XX, comenta o jogo de atração e repulsão do artista com o silêncio: "Não há superfície neutra, discurso neutro, tema ou forma neutras. Uma coisa é neutra apenas com relação a algo mais - como uma intenção ou uma expectativa. Enquanto propriedade da obra de arte em si, o silêncio pode existir apenas num sentido arquitetado ou não literal. (Colocando-se de outro modo: se uma obra de arte existe de alguma forma, seu silêncio é apenas um elemento nela.) Em lugar do silêncio puro ou alcançado encontram-se vários movimentos no sentido de um sempre retrocedente horizonte de silêncio - movimentos que, por definição, jamais podem ser plenamente consumados". Ver em: SONTAG, Susan. A estética do silêncio. In: A vontade radical: estilos. Trad. MARTINS FILHO, João Roberto. São Paulo: Companhia das Letras, 2015, p. 17. 


\title{
CAPÍTULO II: “O palco das metamorfoses: entre mecanismos artificiais e máscaras grotescas"
}

\begin{abstract}
Mesmo com a ornamentação de bom gosto e com o aspecto altamente enigmático e prodigioso do autômato, o interesse do público teria diminuído, se o artista não tivesse sido capaz de atrair espectadores sempre com uma novidade.
\end{abstract}

(E. T. A. Hoffmann)

Um mágico que perde o controle de seus poderes e cujos feitiços transformam tudo ao seu redor; um homem que emagrece até se transformar numa pequena bolinha; uma mulher que devora navios e engorda incessantemente; outra que dá à luz de maneira ininterrupta crianças com aparência de bonecos; um coelhinho que se metamorfoseia em inúmeros animais; um homem que assume a forma de um dromedário; outro que vê suas mulheres transformarem-se uma na outra; um edifício que cresce infinitamente. Os resultados das mutações são inesperados e abrangem a transgressão das fronteiras dos reinos da natureza - humano, vegetal e animal assim como a transformação de seres vivos em objetos, concebendo, inclusive, seres híbridos e desconhecidos, e também o descomedimento dos limites dos corpos, que podem aumentar ou diminuir indefinidamente, originando seres aberrantes.

Presentes em quase a metade dos 33 contos publicados de Murilo Rubião, as metamorfoses figuram recorrentemente como tema na obra do autor, além de apresentarem-se como um dos processos que engendram as situações caracteristicamente sobrenaturais de suas narrativas. Tema e procedimento, como notou Davi Arrigucci Jr. ${ }^{74}$, o movimento metamórfico tanto pode representar somente um dos fios que compõem o efeito insólito da trama como o assunto central que a sustenta. Em certos contos, as transformações resultam em mudanças espaciais e corporais que dão origem, por sua vez, a novas alterações, desencadeando uma sucessão veloz de imagens sobrepostas; já em outros, há, ao longo da narrativa, o processo gradual de apenas uma metamorfose. Tudo está suscetível à metamorfose na prosa de Rubião, seja de maneira voluntária, a partir do desejo de mudança, como no conto Alfredo, seja - mais frequentemente - de maneira involuntária, quando ela se impõe como característica inerente aos personagens.

\footnotetext{
${ }^{74}$ ARRIGUCCI JR, Davi. O seqüestro da surpresa, In: Outros achados e perdidos. São Paulo: Companhia das Letras, 1999, pg. 307.
} 
Neste capítulo detalharemos, portanto, os mecanismos que regem os principais movimentos metamórficos dos contos de nosso autor. Para isso, além de esmiuçarmos as transfigurações que se sucedem dentro de suas narrativas, também faremos uma análise comparativa entre tais procedimentos e aqueles encontrados na obra de outros escritores que também trabalharam da metamorfose, como Franz Kafka e Lautréamont. A partir desse paralelo, mostraremos a face superficial e espetacular das metamorfoses, cuja inacessibilidade e multiplicação lembra passes de mágico ou a pirotecnia - dois temas trabalhados pelas narrativas de Murilo Rubião. Por fim, veremos as relações estabelecidas entre as metamorfoses e os aspectos formais e estilísticos do conto, uma vez que o caráter hiperbolicamente grotesco e reiterado desses processos influencia diretamente no resultado estético dos contos e, também, em seu humor mordaz e irônico.

\title{
1. A criação do efeito insólito
}

No conto $O$ ex-mágico da Taberna Minhota, acompanhamos o conflito entre um mágico e seu desejo de escapar aos seus dons extraordinários. A razão nos é evidente - seus dotes mágicos deixaram de ser puramente ilusórios e tornaram-se realidade. Se, no início, seus truques rendiam-lhe fama e a admiração do público, aos poucos eles fogem do controle e passam a ser um estorvo para a cidade, vítima de seus encantamentos:

\begin{abstract}
Quase sempre, ao tirar o lenço para assoar o nariz, provocava o assombro dos que estavam próximos, sacando um lençol do bolso. Se mexia na gola do paletó, logo aparecia um urubu. Em outras ocasiões, indo amarrar o cordão do sapato, das minhas calças deslizavam cobras. Mulheres e crianças gritavam. Vinham guardas, ajuntavamse curiosos, um escândalo. Tinha de comparecer à delegacia e ouvir pacientemente da autoridade policial ser proibido soltar serpentes nas vias públicas. Não protestava. Tímido e humilde mencionava a minha condição de mágico, reafirmando o propósito de não molestar ninguém. ${ }^{75}$
\end{abstract}

Além de se tornar uma ameaça à ordem pública, o mágico também sente os sintomas do profundo tédio em que mergulha devido ao descontrole dos encantamentos originados meramente por sua presença, à revelia de palavras enfeitiçadas ou de rituais fantásticos. A sua condição de mágico, como o próprio narrador-protagonista assinala, reduz seus feitos a uma rotina ordinária da qual ele anseia libertar-se. No entanto a alternativa de tornar-se funcionário público para eliminar seus dons mostra-se igualmente aterradora, pois, livre dos incômodos que sua mágica lhe causava, ele se vê preso a uma nova rotina ainda mais enfadonha. Sequer a paixão por uma colega de trabalho consegue distraí-lo de sua penosa profissão, não restando

\footnotetext{
${ }^{75}$ RUBIÃO, Murilo. O ex-mágico da Taberna Minhota. In: Murilo Rubião: obra completa. Op. cit. pg. 23.
} 
nele senão o arrependimento por não ter instaurado, quando havia a possibilidade, um novo mundo com seus antigos poderes.

O tédio do narrador contrasta com o mundo mágico que ele é, ou era, capaz de conjurar e que subverte a ordem natural das coisas ao impor o insólito como regra. Nessa nova ordem, tudo pode ser transformado e não há limites ou fronteiras entre seres vivos e objetos. Assim, um jacaré que se metamorfoseia em sanfona, uma pistola que se torna um lápis no momento do disparo, leões que falam e comportam-se como humanos passam a integrar a normatividade cotidiana e deixam de causar espanto no leitor e nos personagens. A repetição, entretanto, banaliza as metamorfoses e esvazia seu caráter extraordinário.

Embora os acontecimentos fantásticos naturalizem-se dentro dos limites da fábula, o efeito insólito garante-se por outros meios composicionais. Há uma indeterminação, por exemplo, criada pelas marcas de temporalização e de espacialização. Longe de criar uma atmosfera completamente vaga quanto à época em que transcorre a história ou quanto ao lugar em que ela se passa - semelhante ao "era uma vez" dos contos de fada e dos outros gêneros que se desenrolam no universo maravilhoso - o conto $O$ ex-mágico da Taberna Minhota, por sua vez, também não oferece informações categóricas a respeito dessas duas dimensões.

Sobre o tempo, há o dado preciso de que os acontecimentos se passam próximos ou durante os anos 1930 e 1931. Essa informação, porém, relativiza-se por intermédio da discussão entre o mágico e seu patrão, quando aquele pensa já estar trabalhando há dez anos na repartição pública e este responde-lhe: "Jamais poderia esperar de alguém, com um ano de trabalho, ter a ousadia de afirmar que tinha dez" ${ }^{76}$. De maneira similar, a descrição do espaço ladeia-se de maneira pouco detalhada e resume-se a algumas informações de lugares fictícios como a "taberna Minhota" e o "Circo Parque-Andaluz", ou de ambientes com graus diferentes de especificidade, que podem variar de "a serra" até "uma Secretaria de Estado".

A narrativa situa-se, portanto, sob uma atmosfera que oscila entre a familiaridade com o mundo mimético, com o universo que o leitor reconhece como similar ao seu, e a estranheza de elementos fugidios e imprecisos. Segundo Audemaro Taranto Goulart: "uma vez que o mundo que aparece nas narrativas murilianas, por força de se submeter à regência do fantástico, acaba sendo alcançado por um processo corrosivo que o descaracteriza inteiramente como realidade conhecida"77. O efeito insólito, contudo, apenas o leitor consegue sentir, uma vez que

\footnotetext{
${ }^{76}$ Idem, ibidem. pg. 25.

77 GOULART, Audemaro Taranto. Modernidade e melancolia na obra de Murilo Rubião. In: MARQUES, Reinaldo e SOUZA, Eneida Maria de (org.). Modernidades e alternativas na América Latina. Belo Horizonte: Editora UFMG, 2009, pp. 148-149.
} 
os personagens encaram as metamorfoses e os outros acontecimentos fantásticos com total naturalidade.

Jorge Schwartz também aponta para o jogo estabelecido por nosso autor entre o verossímil e o inverossímil, entre o os aspectos "sólitos", "insólitos" e "sobrenaturais" de sua prosa, esclarecendo as estratégias do autor para naturalizar os elementos sobrenaturais e para que seu discurso não caia na ambiguidade e seja interpretado como sonho ou delírio ${ }^{78}$. Para isso, o crítico elenca os aspectos prosaicos e rotineiros da trama que contrabalanceiam a sua dimensão extraordinária, além de enfatizar a ausência de perplexidade dos personagens diante das metamorfoses, dos animais falantes e de outros acontecimentos inexplicáveis. Ao descrever o movimento pendular que vai do espantoso ao trivial incessantemente, Schwartz conclui que esse equilíbrio entre "sólito" e "sobrenatural" ajuda a garantir a verossimilhança discursiva dos contos de Rubião e, consequentemente, o efeito insólito na leitura, que fascina e surpreende o leitor $^{79}$.

Acrescenta-se a tal efeito o estilo costumeiro, cristalino, seco e sem inovações do autor. Apesar de suas narrativas estarem repletas de transgressões à ordem natural das coisas, o controle na descrição dos acontecimentos fantásticos e a escassa adjetivação dos mecanismos insólitos reforça a sensação de estranhamento diante da atmosfera criada por Rubião. Enquanto tudo dentro da narrativa parece estar fora de direção, seu estilo prosaico contribui para a naturalização do absurdo dentro da fábula e, em contrapartida, intensifica o espanto do leitor. Rui Mourão comenta esse choque entre os eventos fantásticos presentes nos contos e sua linguagem vigiada, que ele compara à de Machado de Assis:

Um aspecto geral comum aos dois autores é o contraste entre uma linguagem policiada, disciplinada, despojada - rigorosamente enquadrada na lógica gramatical mais cristalina - e uma invenção de mundo fantasista, alucinada e ingovernável. No plano da frase, o escritor está sempre à cata do termo próprio, da precisão substantiva, se excede no uso de elementos de ligação, de desdobramentos explicativos; no plano das unidades superiores à frase, está sempre à procura do vago, da duplicidade significante, se desmanda no uso de elementos que visam à desconexão, à produção do desconforto e das surpresas chocantes. Parece que o objetivo é o de deixar o leitor pisando ao mesmo tempo no plano do lógico e do ilógico, do verossimilhante e do desconhecido - numa continuada denúncia do que na realidade existe de incongruente e de compósito. ${ }^{80}$

\footnotetext{
${ }^{78}$ SCHWARTZ, Jorge. Murilo Rubião: a poética do Uroboro. São Paulo: Ática, 1971, pp. 54-65.

79 Jorge Schwartz baseia-se, aqui, nos conceitos de efeito de real de Roland Barthes, estruturado a partir da diferença entre verossimilhança referencial e verossimilhança discursiva. Enquanto esta possui referências apenas no plano discursivo, no universo fictício construído pelo autor, aquela constrói-se a partir das referências contextuais do mundo não-fictício do leitor. Ver em: BARTHES, Roland. O efeito do real. In: O rumor da língua. Trad. LARANJEIRA, Mario. São Paulo: Martins Fontes. 2004.

${ }^{80}$ MOURÃO, Rui. O pirotécnico Zacarias. In: Revista Colóquio. Lisboa, no 25, maio de 1975. Disponível em: http://www.murilorubiao.com.br. Último acesso: 19/06/2018.
} 
Nelly Novaes Coelho também destaca a importância da escrita contida e segura de Murilo Rubião a fim de garantir o efeito insólito de seu universo ficcional. Para a crítica, o estilo do autor torna sua narrativa "real e irreal ao mesmo tempo", em que sua linguagem "seca e neutra, de quase relatório" cria a "atmosfera sobrenatural que seus temas exigem" 81 .

Parte dos mecanismos extraordinários presentes nos contos de Rubião, as metamorfoses também são descritas com o mesmo estilo neutro e controlado. Em $O$ ex-mágico da Taberna Minhota, as transformações se sucedem rapidamente, com poucos detalhes e com tamanha naturalidade que, ironicamente, os efeitos mágicos ganham um aspecto artificial. Como já afirmamos anteriormente, as constantes mudanças causadas pelo mágico carecem de causalidade e - embora tenham o poder de transformar tudo o que está ao seu redor e assegurar diversas metamorfoses surpreendentes e inusitadas - caem na redundância ao se repetirem exaustivamente.

Essa linguagem técnica, redundante, repetitiva, de "quase relatório" contradiz a expectativa ante a narração em primeira pessoa, recurso utilizado em $O$ ex-mágico e na maior parte da obra de Murilo Rubião, como nos contos Bárbara, O pirotécnico Zacarias, Teleco, o coelhinho, Alfredo, O homem do boné cinzento, Os três nomes de Godofredo e outros. Segundo Norman Friedman - em seu texto que se volta aos diferentes tipos de ponto de vista na ficção -, a narração em primeira pessoa pressupõe mais subjetividade, envolvimento emocional, expressões dramáticas e menor controle dos episódios da trama. Uma vez que o foco narrativo parte de um olhar "centralmente envolvido na ação", no caso do protagonista, ou da "periferia nômade", no caso da testemunha, a narração ganha um aspecto mais passional e impreciso, sobretudo a contada pelo herói ${ }^{82}$.

Quando a narração, no entanto, deixa de ser contada no ato para ser realizada ulteriormente sob a forma de relato (ou relatório), como acontece nesses contos de Rubião, a distância entre os dois momentos - que nunca se revela - parece relativizar a sentimentalidade do narrador. Sem se preocupar em explicar os acontecimentos insólitos que permeiam as histórias e sem manifestar espanto ou estupefação, ele satisfaz-se em desafogar uma lembrança que parece não compreender. Daí surgem os inícios abruptos de narração, típicos de desabafos amargurados, como em $O$ ex-mágico: "Hoje sou funcionário público e este não é meu desconforto maior" 83 ; em $O$ homem do boné cinzento: "O culpado foi o homem do boné

\footnotetext{
${ }^{81}$ COELHO, Nelly Novaes. Os dragões e.... In: Estado de São Paulo. Suplemento Literário. São Paulo, 06 de agosto de 1996. Disponível em: http://www.murilorubiao.com.br. Último acesso: 19/06/2019.

${ }^{82}$ FRIEDMAN, Norman. O ponto de vista na ficção: o desenvolvimento de um conceito crítico. Trad: MELO, Fábio Fonseca de. Revista USP. São Paulo, nº 53, pp. 175-177, março/maio 2002.

${ }^{83}$ RUBIÃO, Murilo. O ex-mágico da Taberna Minhota. In: Op. cit. pg. 21.
} 
cinzento. Antes da sua vinda, a nossa rua era o trecho mais sossegado da cidade" 84 e em Bárbara: "Bárbara gostava somente de pedir. Pedia e engordava. Por mais absurdo que pareça, encontrava-me sempre disposto a lhe satisfazer os caprichos" $" 85$.

José Paulo Paes ressalta a ausência de entendimento dos personagens diante dos acontecimentos sobrenaturais que lhes afligem ou afligiram e a solidão a que eles estão condenados na busca por compreensão:

\begin{abstract}
E é precisamente pela ausência de uma instância transcendente de onde teria supostamente de emanar que a sobrenaturalidade adquire, nos contos de Murilo Rubião, um caráter ominoso. Seus protagonistas são vítimas de surpresas e castigos monstruosos cuja fonte desconhecem, e é por desconhecê-la que se veem de todo inermes, não lhes restando sequer o recurso da prece intercessiva à Divindade ou de resignação ante a Sua insondável vontade, a qual peca por ausente, ou pior ainda, por inexistente. ${ }^{86}$
\end{abstract}

Vítimas, antes de tudo, das metamorfoses e dos outros fatos insólitos que se tornaram demasiadamente rotineiros e vazios de transcendência, impossibilitados de buscar auxílio em dimensões superiores e incapazes de interpretar e de explicar a própria biografia, não resta aos heróis dos contos citados senão a alternativa de lamentar, posteriormente, a própria inércia, buscando algum alívio em seus desabafos.

O salto no tempo entre o momento da narração e o momento dos acontecimentos narrados contribui, portanto, para intensificar a descrição fria e pouco pormenorizada das metamorfoses e das outras circunstâncias insólitas. Uma vez que elas não são narradas ao mesmo tempo em que são observadas pelo protagonista ou pela testemunha, não há mais lugar para admiração. A indiferença - consequência também e sobretudo da banalização do extraordinário - instaura-se e domina a exposição da história. O tom confessional do narrador, por seu lado, intensifica a possibilidade do universo fictício do autor ao aproximar-se para ganhar a confiança e a anuência do leitor. Com isso, ele fortalece o efeito insólito, harmonizando dados miméticos e ocorrências sobrenaturais ao longo de seu relato, cuja verossimilhança está envernizada pelo tempo que se transpôs.

\title{
2. Comparações: as metamorfoses de Kafka e de Lautréamont
}

A estrutura narrativa posterior aos acontecimentos narrados consolida-se mesmo nos contos de Rubião narrados em terceira pessoa, por um narrador onisciente. O mesmo início abrupto das

\footnotetext{
$84 \ldots$ O homem do boné cinzento. In: Op. cit. pg. 151.

85 . Bárbara. In: Op. cit. pg. 27.

${ }^{86}$ PAES, José Paulo. Um sequestro do divino. In: A aventura literária: ensaios sobre ficção e ficções. São Paulo: Companhia das Letras, 1990, pg. 122.
} 
narrativas em primeira pessoa também está presente nesses outros contos, assim como o tom de desabafo e de indignação passiva, com a única diferença de que o "eu" transforma-se em “ele”. Em Os comensais, por exemplo, o narrador já adianta os sentimentos e as impressões do herói Jadon, que serão reforçados ao longo da narrativa, logo nas primeiras frases: "Desde o primeiro contato Jadon admitiu a precariedade das suas relações com os companheiros de refeitório. E a atitude de permanente alheamento que assumiam na sua presença, ele a recebeu como possível advertência" ${ }^{\prime 87}$. O mesmo início engatilhado está presente em Petúnia: "Nem sempre amou Petúnia. Mas não sabia de quem a tivesse amado tanto, enquanto Petúnia" ${ }^{" 88}$ e em Botão-de-rosa: "Quando, numa segunda-feira de março, as mulheres da cidade amanheceram grávidas, Botão-de-Rosa sentiu que era um homem liquidado" 89 .

Quer por meio de uma constatação sentimental ou opinativa, quer ao antecipar eventos que só serão esclarecidos mais adiante na narrativa, tais enunciados - especialmente o último chamam a atenção por lançarem o leitor, subitamente e sem explicações, no universo insólito da narrativa. Enquanto a marcação temporal - numa segunda-feira de março - garante a familiaridade e a aderência do leitor, o fator sobrenatural - todas as mulheres de uma cidade amanhecerem grávidas - desperta seu espanto e sua suspeita. As informações decorrentes ou anteriores a essa afirmação deverão ser, gradualmente, tateadas pelo leitor. Tal estratégia assemelha-se à utilizada por Franz Kafka no início de alguns de seus romances e contos, como em A metamorfose: "Quando certa manhã Gregor Samsa acordou de sonhos intranquilos, encontrou-se em sua cama metamorfoseado num inseto monstruoso" ${ }^{\prime 90}$.

Modesto Carone ressalta que o "efeito de choque" causado pelo início abrupto da narrativa e sua linguagem "tipicamente cartorial, de protocolo" fascinam o leitor, que se sente atraído e, ao mesmo tempo, repugnado pela metamorfose em inseto de um homem aparentemente comum numa manhã qualquer, restando a ele seguir uma leitura em que há "o desconforto de se deparar com uma narração translúcida, mas cujo ponto de partida permanece opaco" 91 .

Ainda segundo Carone, o início da narrativa a partir de seu clímax é fundamental para manter em segredo as razões do acontecimento insólito que acaba de acontecer, tornando-se "um enigma não só para quem lê como também para o próprio herói" ${ }^{92}$, impondo às duas

\footnotetext{
${ }^{87}$ RUBIÃO, Murilo. Os comensais. In: Op. cit. pg. 216.

88 _. Petúnia. In: Op. cit. pg. 183.

89 . Botão-de-Rosa. In: Op. cit. pg. 207.

90 KAFKA, Franz. A metamorfose. In: CARONE, Modesto (org. e trad.). Franz Kafka: essencial. São Paulo: Penguin Classics Companhia das Letras, 2011, pg. 227.

${ }^{91}$ CARONE, Modesto. A metamorfose. In: Op. cit. pp. 211-212.

92 Idem, ibidem. pg. 212.
} 
instâncias uma busca infrutífera por respostas que desvelem o segredo da metamorfose de Samsa. Tal busca, entretanto, será pouco a pouco esquecida em virtude do esforço do narrador "para que o leitor acabe se esquecendo até do caráter ilusionista da própria ficção, compensando o abalo inicial da história com a notação minuciosa e quase naturalista dos seus desdobramentos" $" 93$. Além disso, o narrador em terceira pessoa, que ora se cola aos pensamentos e às sensações do protagonista, ora se afasta deles, garante a descrição fria e ao mesmo tempo desesperadora das engrenagens do novo organismo do protagonista e reforça o efeito insólito da leitura ${ }^{94}$.

A respeito do tema, o próprio espanto em relação à transfiguração de Gregor Samsa será discutido pelo crítico, uma vez que a figura da metamorfose é tradicional na literatura e está presente em diversas tradições e gêneros literários, algo que deveria facilitar a compreensão do leitor diante do homem demudado em inseto:

Entretanto é evidente que o tema da metamorfose não é novo em literatura: os mitos
clássicos e as fábulas, as narrativas dos povos primitivos e os contos de fadas são ricos
em acontecimentos como esse. Mas nenhum leitor esclarecido fica perturbado com
eles, não só porque essas metamorfoses em geral são reversíveis como também porque
podem ser logo percebidas como manifestações de um estágio de consciência
ingênuo, pré-científico, que exime o leitor de julgá-las segundo os padrões da sua
própria experiência. Assim é que aceitamos que Circe, na Odisseia, metamorfoseie os
companheiros de Ulisses em porcos, ou que, num conto de Grimm, o filho do rei vire
sapo até que uma princesa o devolva à sua condição natural - justamente porque
nesses casos vigora o princípio da diferença entre o mundo empírico conhecido e o
mundo mágico, fantástico ou irônico da poesia, o que nos coloca na postura certa
enquanto leitores. É esse princípio que parece faltar em A metamorfose, e talvez seja
por isso que dela se desprende uma sensação extraordinariamente perturbadora e
penosa que nos põe em atitude de defesa.

À vista disso, o critério essencial para a aceitação ou não da metamorfose por parte do leitor, diz Carone, está no princípio da diferença entre a organização do nosso mundo empírico e a que estrutura o mundo mágico, mítico ou maravilhoso da poesia. A metamorfose de Samsa, desse modo, contraria tal dinâmica ao realizar-se dentro de uma casa de classe média urbana e vitimar um caixeiro-viajante. Ela se dá de maneira incompatível com a realidade e com o

\footnotetext{
93 Idem, ibidem. pg. 213.

${ }^{94}$ Sobre a narração em Franz Kafka, Theodor Adorno ratifica como a acentuada proximidade entre personagem e leitor, que exige, de modo constante, a afetuosidade e a participação deste ante a tragédia insólita daquele, leva, contraditoriamente, ao afastamento e à falta de identificação, uma vez que o compartilhamento das experiências é tamanho que o leitor pode passar a enxergar a estranheza de sua própria realidade, come se não houvesse mais distinção entre vida e fícção: "Entre los presupuestos de Kafka no es el menor la fundamental perturbación de la relación contemplativa entre el texto y el lector. Sus textos pretenden que no exista entre ellos y su víctima una distancia constante; agitan de tal modo la afectividad del lector que éste tiene que temer que lo narrado se le eche encima como las locomotoras al público en los comienzos de la técnica cinematográfica tridimensional. Tal agresiva proximidad física coarta la costumbre del lector de identificarse con figuras de la novela". Ver em: ADORNO, Theodor W. Apuntes sobre Kafka. In: Prismas - la crítica de la cultura y la sociedad. Trad. SACRISTÁN, Manuel. Barcelona: Ediciones Ariel, 1962, pg. 262

${ }^{95}$ CARONE, Modesto. Op. cit. pg. 213-214.
} 
contexto social dessa família e explica a vergonha dos pais e da irmã de Samsa ao lidarem com o seu irmão que se transformou um inseto monstruoso. Não por acaso, dada a irreversibilidade da metamorfose ${ }^{96}$, o único desfecho possível para o herói prefigura-se na sua eliminação - ou seja, a sua morte - para que sua família volte a viver de forma pacífica e, ironicamente, melhor.

Os contos de Murilo Rubião, no entanto, organizam-se de maneira diferente no que se refere à narração e à descrição da metamorfose presentes na novela de Kafka. Se, por um lado, a clareza da escrita, as referências ao mundo empírico, a prostração dos personagens diante dos enigmas fantásticos, a metamorfose compulsória e o início abrupto estão presentes em ambas as prosas, garantindo o efeito insólito e o desconforto do leitor diante dos acontecimentos extraordinários, há, por outro lado, elementos dessemelhantes na construção narrativa e descritiva das metamorfoses que implicam modificações formais e, consequentemente, impactos diferentes no ato da leitura.

Em O homem do boné cinzento, por exemplo, acompanhamos o interesse curioso e obstinado de dois irmãos, Roderico e Artur, pela mudança e pela decorrente instalação na casa ao lado do novo vizinho, Anatólio. O conto, narrado em tom de desabafo por Roderico, já indica de início que essa mudança foi responsável pela perda da tranquilidade dos dois irmãos e de toda a vizinhança, embora a razão não seja esclarecida. $\mathrm{O}$ narrador, que, a princípio, não esboçava qualquer interesse em relação ao novo habitante da rua, limita-se a contar aquilo que escutava de seu irmão Artur, já dedicado a espreitar, nos mínimos detalhes, a vida de Anatólio, cujos hábitos excêntricos também despertavam o interesse dos outros moradores. Roderico mantém-se desinteressado mesmo com as afirmações espantosas de Artur de que o vizinho estava a cada dia mais e mais magro. O narrador só espia o vizinho a partir do momento em que este começa a ficar transparente. De tão reduzida a sua forma, Anatólio contrai-se em vômitos incandescentes que se espalham pela cidade e levam-no à combustão, restando nada mais que seu cachimbo e sua cabeça coberta pelo boné. Logo após o incidente, o narrador percebe que seu irmão, tomado pela excitação diante da tragédia com o vizinho, começa a diminuir exponencialmente, até quase sumir: "Peguei-o com as pontas dos dedos antes que desaparecesse

\footnotetext{
96 Assim como afirma Carone no texto supracitado, a maior diferença da metamorfose kafkiana para aquelas encontradas nas mitologias e nos contos de fada é a sua irreversibilidade. Tanto na obra do escritor tcheco quanto nas histórias míticas ou feéricas, a metamorfose é inexplicável e assim deve ser encarada pelo leitor, embora nestas elas sejam desencadeadas por algum encantamento, alguma maldição ou alguma poção ou objeto mágico. No entanto a condição de reversibilidade do acontecimento mágico, como aponta Vladimir Propp, é um dos aspectos fundamentais das histórias maravilhosas. Ou seja, para todo malfeito do vilão há um antídoto capaz de restabelecer a ordem original das coisas e de garantir o desfecho feliz dos personagens bons. Todavia essa opção não existe para Samsa. Ver em: PROPP, Vladimir. Morfologia do conto maravilhoso. Rio de Janeiro: Forense - Universitária, 1984.
} 
completamente. Retive-o por instantes. Logo se transformou numa bolinha negra, a rolar na minha mão" $"$.

A incineração do corpo de Anatólio e a metamorfose de Artur numa bolinha negra são unicamente testemunhadas, portanto, por Roderico. O próprio processo de emagrecimento e apagamento do corpo do vizinho não é observado pelo narrador senão nos seus últimos instantes, já que o início dessa transformação era narrado indiretamente por Artur. Assim, as duas transformações corporais presentes na narrativa são simplesmente percebidas, vistas e após um espaço de tempo indeterminável entre a fábula e o momento da narração - contadas por Roderico.

Há entre os acontecimentos sobrenaturais e o relato de Roderico duas instâncias que os separam. A primeira é o fato de o narrador também ser, na maior parte da história, apenas o ouvinte das resenhas de seu irmão a respeito do emagrecimento inexplicável de Anatólio. Ou seja, um grande fragmento do que é agora narrado foi meramente escutado por Roderico e reproduzido, posteriormente, por suas próprias palavras. A segunda é a distância que separa, com efeito, os acontecimentos e o ato da narração, estratégia comum a todos os contos de Murilo Rubião narrados em primeira pessoa. Desse modo, as metamorfoses presentes em $O$ homem do boné cinzento são narradas e descritas no conto de maneira bastante indireta e exclusivamente a partir da observação e das impressões do narrador. Há um afastamento fundamental entre o processo metamórfico e a sua descrição por parte de Roderico, separados pela distância temporal e pela distância corporal, uma vez que ele não foi a vítima de tais transformações.

Theodor Adorno afirma que, em Kafka, o narrador elimina a distância estética ao colar leitor e personagem na mesma angústia e no mesmo sofrimento, fazendo de ambos as suas vítimas $^{98}$. Roberto Schwarz faz coro às palavras de Adorno ao afirmar que, em A metamorfose: "O percurso do foco narrativo é sempre o mesmo: da descrição objetiva de Gregor passa para dentro dele, dá início ao discours vécu. A volta, entretanto, não se faz gradual, mas bruscamente" 99 . A metamorfose sofrida por Gregor Samsa, embora seja narrada em terceira pessoa e já esteja consumada no início do conto, é sentida e experimentada pelo leitor como se ele próprio fosse a vítima desafortunada. Vagarosa e sofregamente, ela é detalhada pelo

\footnotetext{
${ }^{97}$ RUBIÃO, Murilo. O homem do boné cinzento. In: op cit. pg. 155.

98 ADORNO, Theodor. Op. cit. pg. 262.

${ }^{99}$ SCHWARZ, Roberto. Uma barata é uma barata é uma barata. In: A sereia e o desconfiado. Rio de Janeiro: Paz e Terra, 1981, pg. 66.
} 
narrador a fim de compelir quem está fora da consciência de Samsa a sentir-se dentro das fronteiras físicas do inseto monstruoso.

Gaston Bachelard, ao comparar a metamorfose infligida ao herói kafkiano àquelas produzidas e exortadas pelos Cantos de Maldoror, de Lautréamont, nota a lentidão, a letargia e a apatia acarretadas pela transformação de Samsa em inseto, efeitos completamente opostos aos originados pelas metamorfoses agressivas, violentas, sedentas de vida e de movimento que fervilham o corpo de Maldoror. Para Bachelard, a metamorfose em Kafka é consequência de um "mal profundo", de um "mal longínquo", que já estava dentro do protagonista e que, repentinamente, dominou seu corpo:

Parece que, no autor alemão, a metamorfose sempre é uma infelicidade, uma queda, um entorpecimento, um afeamento. De uma metamorfose, morre-se. Diríamos que Kafka sofre de um complexo de Lautréamont negativo, noturno, negro. E o que talvez prove o interesse de nossas pesquisas sobre a velocidade poética e sobre a riqueza temporal é que a metamorfose de Kafka aparece nitidamente como um estranho afrouxamento da vida. [...] Gregor, pouco a pouco, cobre-se de visgo, ele cola nas paredes; ele vive num mundo coagulado, num tempo viscoso; ele coxeia estabanadamente; ele é embotado, chega sempre depois, depois de uma ideia, de uma sensação. ${ }^{100}$

Ao descrever a metamorfose em Kafka, Bachelard também ressalta, além do seu caráter letárgico, a capacidade que o leitor tem de experimentar essa transformação como se ele próprio a tivesse sofrido. De maneira indireta, elencando precisa e esmiuçadamente as sensações suportadas por Samsa em razão de sua nova matéria, o filósofo francês afirma a capacidade do narrador kafkiano de eliminar a distância estética entre as instâncias da narração e da leitura e, assim, lançar o leitor para dentro das fronteiras do corpo de um inseto.

O mesmo processo de experimentação das metamorfoses por parte do leitor aconteceria em Lautréamont com o seu personagem Maldoror, tão-somente invertendo os sinais - aquilo que é negativo e funesto em Kafka passa a ser positivo e vigorante no escritor franco-uruguaio. Nos cantos, tal como na obra de Murilo Rubião, há a perda total dos limites entre os seres humanos, as plantas, os animais e o mundo material - tudo é cambiável e permeável. No entanto, as metamorfoses de Maldoror são uma manifestação de potencialidade, de fibra e de ímpeto. Como afirma Bachelard: "em Lautréamont, a palavra encontra imediatamente a ação. [...] Lautréamont é um dos maiores devoradores do tempo. Este é, como demonstramos, o segredo da sua insaciável violência"101. As metamorfoses de Maldoror não são somente abertas

\footnotetext{
${ }^{100}$ BACHELARD, Gaston. Lautréamont. Trad. ALMEIDA, Fábio Ferreira. Goiânia: Edições Ricochete, 2013, pg. 9. Grifos do autor.

${ }^{101}$ Idem, ibidem. pg. 5.
} 
e acessíveis, elas têm sobretudo o poder de arrebatamento do leitor, de arremessá-lo dentro do turbilhão de formas do universo ducassiano. ${ }^{102}$

Como aponta Claudio Willer ao comentar a obra de Lautréamont, as metamorfoses desenvolvem-se nos cantos como uma "expressão de rebelião", como ato de uma "revolta individual" ressaltada pela própria comparação estabelecida, em algumas estrofes, entre Maldoror e Lúcifer, o "mais importante símbolo da rebelião na tradição ocidental"103. As palavras do protagonista também exaltam manifestamente a sua necessidade de se metamorfosear como uma possibilidade de experimentar momentos jubilosos: "A metamorfose nunca apareceu a meus olhos senão como elevada e magnânima ressonância de uma felicidade perfeita, que esperava há muito"104. Nesse universo em que tudo está em constante modificação, não é apenas o protagonista Maldoror que está suscetível às metamorfoses - o tempo e o espaço sofrem mutações ao longo das estrofes, assim como figuras da retórica, citações literárias, referências históricas, termos científicos e o próprio autor, que oscila entre a primeira pessoa, na voz do protagonista, e um narrador neutro em terceira pessoa que acompanha as aventuras do herói dos cantos.

\section{O espetáculo das metamorfoses}

Se as metamorfoses em Kafka e Lautréamont podem ser consideradas opostas quanto aos seus efeitos e às suas consequências no nível da trama e no nível da leitura, pela natureza positiva de uma e negativa de outra, em contrapartida, ambas são igualmente violentas em sua narração e em sua descrição, incitando uma narrativa que pulsa a partir dos resultados dos processos metamórficos. Hábeis na captura do leitor para dentro da pele de seus personagens, tanto $A$ metamorfose como Os cantos de Maldoror são textos em que experimentamos a metamorfose de maneira lúcida e operante.

\footnotetext{
${ }^{102}$ A permeabilidade de todas as formas encontradas na natureza, que cria um universo em constante metamorfose dentro da obra de Lautréamont, foi a razão fundamental para que os surrealistas franceses da primeira metade do século XX considerassem o escritor franco-uruguaio como o precursor do surrealismo. Lautréamont seria, para esse grupo de artistas e de intelectuais, um surrealista avant la lettre, um escritor já sensível a certas preocupações, temas e métodos de escrita caros ao movimento vanguardista da década de 20 . Na base da sensibilidade surrealista está a ideia de reinventar o mundo a partir de um grau zero no qual todos os elementos se encontrariam em constante transição. O empenho de "atualizar" esse tempo primordial em que as leis biológicas e sociais ainda não pesavam sobre a vida, restando uma total indiferença entre as coisas e os seres, já estaria expressamente formulado por Lautréamont no início de um dos Cantos de Maldoror: "É um homem ou uma pedra ou uma árvore que vai começar o quarto canto". Ver em: MORAES, Eliane Robert. O corpo impossível. São Paulo: Editora Iluminuras, 2010.

${ }^{103}$ WILLER, Claudio. Prefácio: O astro negro. In: LAUTRÉAMONT, Conde de. Os cantos de Maldoror: poesia, cartas, obra completa. Trad. WILLER, Claudio. São Paulo: Iluminuras, 2015, pg. 28.

${ }^{104}$ LAUTRÉAMONT, Conde de. Op. cit. pg. 204.
} 
Comparado a esses textos a partir do mesmo viés, percebemos uma distância entre os dois escritores e o universo fictício de nosso autor. A possibilidade de experimentação não pode ser reconhecida nas metamorfoses encontradas nos contos de Murilo Rubião: elas não são acessíveis ao narrador, seja em primeira seja em terceira pessoa, e muito menos ao leitor. A metamorfose nos contos do nosso autor são ações passadas e narradas tempos depois, além de serem fenômenos unicamente observáveis pelo narrador ou pelo personagem que conduz o foco narrativo. Como já afirmamos previamente, mesmo o tempo pretérito do narrador kafkiano não impede que ele aproxime Samsa e o leitor acirradamente. Já em Rubião, além de a narrativa estar no passado verbal, ela é construída na forma de relato, como se fosse um desabafo abrupto e nada esclarecedor. Soma-se a isso o fato de ela ser, como em Kafka, veiculada num estilo formal, frio e cartorário que a banaliza. Não há as sensações nem sequer os pensamentos daqueles que são as vítimas, com efeito, das metamorfoses, tampouco o ato enérgico de rebeldia e de transgressão característico das transformações de Maldoror.

Em $O$ homem do boné cinzento, as mutações não são descritas senão pela rememoração e pela voz da testemunha dos acontecimentos sobrenaturais. Há uma insistência no aspecto contemplativo do narrador em relação à metamorfose, realçada nas palavras de Roderico: "Eu não tirava os olhos do homem. Sua magreza me fascinava" ${ }^{105}$. O intervalo entre o instante da metamorfose e a sua exposição em palavras é considerável, a distância entre a consciência do metamorfoseado e a fala do narrador é abissal. As metamorfoses nos contos de Murilo Rubião não ganham solidez nem tampouco substância. Elas são acessíveis apenas como figuras achatadas, bidimensionais e sem perspectiva.

Também no conto $O$ ex-mágico da Taberna Minhota, em que o narrador é responsável pelas ininterruptas metamorfoses que acontecem ao seu redor, elas se transformam em espetáculo para os fregueses da taberna e, posteriormente, para o público do circo, como feitiços e truques que deixaram de ser ilusórios, mas que continuam sendo atrativos assombrosos. Além disso, o mágico continua com sua integridade física inabalada, não obstante o mundo metamorfoseado que ele consegue conjurar em torno de si. A metamorfose, então, é uma ocorrência a ser observada - seja por seu horror seja por seu fascínio - tal qual um espetáculo técnico.

Não à toa um de seus contos explora, justamente, impressões pirotécnicas. Em $O$ pirotécnico Zacarias, narrado em primeira pessoa pelo personagem que dá nome ao título, acompanhamos o relato de um morto-vivo que detalha as circunstâncias da sua possível morte

${ }^{105}$ RUBIÃO, Murilo. O homem do boné cinzento. In: Op. cit. pg. 154. 
e da sua inexplicável volta à vida após ser atropelado por um grupo de jovens. O leitor, testemunha da tragédia a partir do relato da vítima, vislumbra os delírios multicoloridos e as lembranças de infância - em evidente referência às alucinações de Brás Cubas - que antecipam a morte de Zacarias. Já morto, o pirotécnico resolve participar da discussão que se havia instaurado entre eles para decidir qual seria o destino do cadáver.

Dado que o próprio defunto estava de pé e participava ativamente do bate-boca entre os rapazes e as moças que estavam no carro, fica decidido que Zacarias se reuniria a eles para divertirem-se juntos pelo resto da noite. $\mathrm{O}$ que o narrador-protagonista não esperava era, na qualidade de defunto, ter adquirido uma nova habilidade que metamorfoseou o mundo ao seu redor:

Do que aconteceu em seguida não guardo recordações muito nítidas. A bebida, que antes da minha morte pouco me afetava, teve sobre o meu corpo defunto uma ação surpreendente. Pelos meus olhos, entravam estrelas, luzes cujas cores ignorava, triângulos absurdos, cones e esferas de marfim, rosas negras, cravos em forma de lírios, lírios transformados em mãos. E a ruiva, que me fora destinada, enlaçando-me o pescoço com o corpo transmudado em longo braço metálico. ${ }^{106}$

Após sua morte, o herói passa a enxergar o mundo de maneira policroma, como se o observasse a partir de um caleidoscópio. A sua profissão de pirotécnico quando vivo torna-se uma condição natural e inescapável para o defunto Zacarias, que não precisa mais de truques nem de técnicas para colorir o mundo - basta-lhe, para isso, abrir os olhos. Assim como os encantamentos do ex-mágico deixam de ser ilusórios e transformam-se em realidade, as pirotecnias de Zacarias também extrapolam suas limitações de transitoriedade para estabelecerem-se como um espetáculo sempiterno, que metamorfoseia os contornos e as cores ao seu redor. Também seu corpo e seus dotes artísticos já não são mais necessários para fabricar o espetáculo de fogos, que se descola da técnica e converte-se em parte inerente de sua natureza.

Como já assinalamos, o conto possui semelhanças com o romance Memórias póstumas de Brás Cubas, de Machado de Assis. Ambos são narrados por um defunto que recorda seu passado e detalha os momentos que antecedem e sucedem sua morte. Há, no entanto, uma discrepância importante entre eles, como afirma Rui Mourão: “A diferença que se pode apontar na situação dos dois personagens é a de que Brás Cubas se apresenta como testemunha entre os vivos, na condição de fantasma imperceptível aos olhares terrenos, enquanto Zacarias permanece na condição de fantasma perceptível"107. Diferentemente de Brás Cubas, que vê na morte uma libertação e a possibilidade de observar e de maldizer os vivos, Zacarias está condenado a passear entre eles e a provar-lhes que morreu na noite do acidente, originando uma

\footnotetext{
${ }^{106}$ RUBIÃO, Murilo. O pirotécnico Zacarias. In: Op. cit. pg. 19.

${ }^{107}$ MOURÃO, Rui. Op. cit. Disponível em: http://www.murilorubiao.com.br. Último acesso: 19/06/2018.
} 
polêmica que alimenta as rodas de conversa da cidade, como afirma o narrador-protagonista no início do conto. As capacidades sobrenaturais em Rubião, mais uma vez, tornam-se maldições das quais os personagens não conseguem escapar e que os condenam a situações aflitivas e irreparáveis.

Em mais um ponto em comum com a trajetória do ex-mágico, Zacarias não é senão o observador das metamorfoses que ele provoca, garantindo a integridade do seu corpo-cadáver. A única narrativa em que essa dinâmica é alterada e o leitor tem acesso, de certa maneira, às etapas do processo metamórfico a partir de um panorama mais próximo daquele que o padece é o conto $O$ lodo.

Embora narrado em terceira pessoa, nele a narração se cola aos pensamentos e às sensações do protagonista Galateu, tornando-se possível acompanhar suas dores ao ter os mamilos transformados em duas feridas de onde brotaram pétalas escarlates. Apesar da dor excruciante, Galateu recusa-se a receber ajuda de sua irmã Epsila e do Doutor Pink, psicólogo que, mesmo após uma consulta frustrada no início do conto, insiste na tentativa de auxiliar o protagonista em suas doenças da mente e do corpo. Decidido a não aceitar o amparo dos outros, Galateu encerra o conto já moribundo devido às feridas e agonizando em sua cama, cercado por sua irmã e pelo médico, que se prepara enfim para a cirurgia: "Circunspecto, abriu o paletó do pijama de Galateu e com o bisturi, retirado da valise, limpou as pétalas da ferida. Epsila, a um sinal do médico, aproximou-se e ambos se debruçaram sobre o corpo do moribundo, enquanto este esboçava imperceptível gesto de asco" ${ }^{08}$.

No conto $O$ lodo, mais uma vez, a metamorfose irrompe de maneira inexplicável e irreversível, punindo seu alvo e condenando-o a um desfecho trágico. Levada às últimas consequências, assim como em $O$ ex-mágico da Taberna Minhota, $O$ pirotécnico Zacarias e $O$ homem do boné cinzento, as transformações que ocorrem no corpo de Galateu são, contudo, um ponto fora da curva dentro da produção muriliana. Desenhada com mais lentidão e minúcia e invocando pormenores a respeito de suas características sensoriais, descrita como "uma ferida sangrenta, aberta em pétalas escarlates" que "exalava um odor fétido"109, a metamorfose dos mamilos de Galateu em pétalas é detalhada a fim de aproximar o leitor de suas sensações e causar a sua repulsa, tal qual A metamorfose de Kafka.

A regra, como já observamos, estabelece que a metamorfose deve acontecer por vias espetaculares, a partir de uma sucessão de imagens substancialmente inapreensíveis. As transformações nos contos de Murilo Rubião desmesuram-se, constroem-se sob o signo do

\footnotetext{
${ }^{108}$ RUBIÃO, Murilo. O lodo. In: Op. cit. pg. 75

109 Idem, ibidem.
} 
extremado, do descomunal, seja pela deformação excessiva, como em $O$ homem do boné cinzento, seja pela multiplicação incessante, como em $O$ ex-mágico da Taberna Minhota. Comparadas aos procedimentos insólitos de outros escritores do realismo fantástico que iniciam suas atividades literárias na primeira metade do novecentos, como Kafka e Borges, ou em meados do mesmo século, como Julio Cortázar - escritores a quem Jaime Alazraki deu a alcunha de neofantásticos ${ }^{110}$-, as metamorfoses, as magias e as pirotecnias de Murilo Rubião expõem um traço muito mais espetacular, incomensurável, incontrolável e interminável.

A sobrenaturalidade na obra do escritor mineiro exagera no seu desafio às normas e aos preceitos do mundo empírico, alargando todos os limites dos corpos, dos espaços e do tempo. Tais traços ficam-nos ainda mais evidentes se comparados com os escritores argentinos comentados por Alazraki. Por exemplo, no conto Carta a uma senhorita em Paris, de Cortázar, cuja estratégia narrativa assemelha-se à de Murilo Rubião - narrado em primeira pessoa num momento ulterior aos acontecimentos da trama - os eventos insólitos emergem de modo consideravelmente mais racional e controlado. Ainda que o narrador não explique o motivo que o leva a vomitar coelhinhos, ele descreve todo o processo com tranquilidade e naturalidade, além de ressaltar frequentemente a quantidade de animaizinhos vomitados e como eles estão dispostos e organizados no armário, para escondê-los da empregada:

\begin{abstract}
Quando sinto que vou vomitar um coelhinho, ponho dois dedos na boca como uma pinça aberta, e espero sentir na garganta a penugem morna que sobe como uma efervescência de sal de frutas. Tudo é rápido e higiênico, transcorre em um brevíssimo instante. Tiro os dedos da boca, e neles trago preso pelas orelhas um coelhinho branco. O coelhinho parece contente, é um coelhinho normal e perfeito, só que muito pequeno, pequeno como um coelhinho de chocolate, mas branco e completamente um coelhinho. Ponho-o na palma da mão, levanto sua penugem com uma carícia dos dedos, o coelho parece satisfeito de haver nascido e bole e esfrega o focinho na minha pele, movimentando-o com essa trituração silenciosa e cosquenta do focinho de um coelho contra a pele de uma mão. Procura comer, e então eu (falo de quando isto acontecia em minha casa de campo) o levo comigo à varanda e ponho-o no grande vaso onde cresce o trevo que plantei para esse fim. O coelhinho levanta bem suas orelhas, envolve o trevo novo com um veloz molinete do focinho, e eu sei que posso deixá-lo e ir embora, continuar por algum tempo uma vida não diferente da de tantos que compram seus coelhos nas granjas. ${ }^{111}$
\end{abstract}

O mesmo comedimento dos eventos sobrenaturais está presente no conto Casa tomada.

Nele, observamos a falta de reação de dois irmãos ao perceberem que certos cômodos de sua casa estão tornando-se, gradativamente, inacessíveis a eles. Assim como os coelhinhos de Carta a uma senhorita em Paris, não há qualquer explicação para a impenetrabilidade dos quartos tomados, tampouco uma reação assombrada por parte dos moradores, que chegam a ver

\footnotetext{
${ }^{110}$ ALAZRAKI, Jaime. ¿Qué es lo neofantástico? In: Mester (UCLA). Los Angeles, Vol. XIX, n 2, 1990.

${ }^{111}$ CORTÁZAR, Julio. Carta a uma senhorita em Paris. In: Bestiário. Trad. FILHO, Remy Gorga. Rio de Janeiro: Nova Fronteira, 1986, pp. 23-24.
} 
vantagens na diminuição da casa: "Mas também tivemos vantagens. A limpeza ficou tão simplificada que mesmo nos levantando muito tarde, às nove e meia por exemplo, não eram onze e já estávamos de braços cruzados" ${ }^{112}$. Ao contrário da narrativa de Rubião, os acontecimentos sobrenaturais no conto de Cortázar desenrolam-se paulatinamente, desestabilizando aos poucos a ordem cotidiana da casa e a rotina dos irmãos. ${ }^{113}$

No caso de Borges, o efeito insólito propaga-se de maneira igualmente gradual. No conto Tlön, Ugbar, Orbius Tertius, por exemplo, acompanhamos a descoberta e posterior investigação do narrador-protagonista - supostamente o próprio autor - a respeito de uma civilização enigmática chamada Tlön, que teria existido havia muitos séculos e que deixou poucos vestígios de sua demora na Terra. Repleta de referências a figuras ilustres, a datas, a livros e a lugares reais ao mesmo tempo em que descortina a existência de um povo e de uma cultura aparentemente fictícia, a narrativa constrói um efeito insólito de verossimilhança que confunde o leitor quanto à veracidade de Tlön. A partir de um jogo de espelhos, em que um mistério leva a outro mistério, arquitetando uma narrativa em mise en abyme, indícios concretos da existência da antiga civilização tomam o mundo do autor - ou seja, o nosso mundo - e, sucessivamente, começam a apagá-lo e a substitui-lo: “O contato e o hábito de Tlön desintegraram este mundo. Encantada com seu rigor, a humanidade esquece e torna a esquecer que é um rigor de enxadristas, não de anjos" $" 114$.

Assim como em Cortázar, há uma discrepância entre os procedimentos borgianos da construção do efeito insólito e aqueles de Murilo Rubião. Ambos os ficcionistas argentinos ainda são legatários, em certa medida, da estratégia narrativa da literatura fantástica do século XIX que, como aponta Tzvetan Todorov ${ }^{115}$, apoia-se na descrição mimética do mundo empírico do leitor para, pouco a pouco, pô-lo em xeque com o desdobramento de episódios inexplicáveis. A diferença é que, enquanto os escritores oitocentistas apoiavam-se na hesitação, por parte do personagem e do leitor, a respeito da veracidade dos eventos sobrenaturais, tanto Borges quanto

\footnotetext{
${ }^{112}$ CORTÁZAR, Julio. Casa tomada. In: Op. cit. pg. 15.

${ }^{113}$ Essa estratégia de desestabilizar o mundo empírico e descortinar, gradualmente, a realidade insólita da trama pode ser observada em quase todos as narrativas do Bestiário de Cortázar e, não à toa, está bastante próxima das concepções acerca do assunto encontradas no célebre texto Alguns aspectos do conto. A intensidade e a tensão no desenvolvimento do conto, a comparação com o efeito de uma fotografia e com o nocaute, conceitos tão caros ao escritor, refletem-se mesmo nos momentos mais sobrenaturais e inexplicáveis de sua narrativa e talvez impeçam a sua exacerbação, mantendo-os sempre na iminência do descomedimento. Ver em: CORTÁZAR, Julio. Alguns aspectos do conto. In: Valise de cronópio. Trad. ARRIGUCCI JR, Davi e BARBOSA, João Alexandre. 2. ed. São Paulo: Editora Perspectiva, 1993.

114 BORGES, Jorge Luis. Tlön, Uqbar, Orbis Tertius. In: Ficções. Trad. ARRIGUCCI JR, Davi. São Paulo: Companhia das Letras, 2007, pp. 32-33.

115 TODOROV, Tzvetan. Introdução à literatura fantástica. Trad. CASTELLO, Maria Clara Correa. São Paulo: Perspectiva. 2008.
} 
Cortázar não deixam espaço para dúvidas - a sobrenaturalidade passa-se por verdadeira, dando como falsa a noção única e inquestionável da realidade.

O confronto entre mundo empírico do leitor e os acontecimentos sobrenaturais não se constitui como uma preocupação tão latente na obra de Murilo Rubião comparado ao embate apresentado por Kafka, Cortázar e Borges. Embora encontremos referências que resvalam num tipo específico de cenário e de época, como em $O$ ex-mágico da Taberna Minhota, geralmente elas são imprecisas e obscuras.

Como apontado anteriormente, os contos de Murilo Rubião costumam equilibrar-se em um espaço-tempo nem totalmente fantástico, como nos contos de fada, nem completamente bafejado pela realidade empírica compartilhada entre leitor e autor. São frequentes as designações "o campo", “o vale”, “a praia”, "a cidade” e outras espacializações imprecisas. A temporalização é ainda mais ignorada e é indicada raríssimas vezes. Conforme Hermenegildo Bastos, o "espaço está imobilizado, retirado do mundo e congelado", e a "temporalidade também perdeu a sua dimensão concreta, ficou entre o ontem e o amanhã, num desajuste temporal"116. Já para Davi Arrigucci, o espaço-tempo em Rubião é esfumaçado por "uma atmosfera onírica, próxima às vezes do pesadelo" em que o leitor, ao acompanhar o narrador, "é levado a assumir o papel de um sonhador cúmplice"117. Devido à imprecisão espaçotemporal dos contos e à falta de limites referenciais concretos, estabelece-se um universo narrativo menos sufocado pela concretude do contexto empírico e com mais liberdade de transgressões sobrenaturais.

Daí irrompem as várias metamorfoses que transfiguram os componentes dos contos, num movimento incessante e, sobretudo, redundante. O efeito insólito sobre o leitor, por sua vez, é diminuído e os acontecimentos sobrenaturais banalizam-se até se tornarem rotineiros. No entanto, entre tantas transformações trágicas, ainda resta a dúvida concernente à tensão da metamorfose dentro da narrativa de Rubião. Afinal, se as metamorfoses não garantem resultados satisfatórios para os seus alvos e não passam de imagens de um espetáculo inacessível, figuras que se sucedem, repetem-se, multiplicam-se e, por fim, arruínam-se, como uma atração pirotécnica, qual a sua incumbência e qual a sua finalidade dentro dos contos?

\footnotetext{
${ }^{116}$ BASTOS, Hermenegildo José. Aglomerações: o espaço do fantástico muriliano. In: Cerrados: revista do curso de pós-graduação em literatura, Brasília, v. 11, p. 9-6, 2001.

117 ARRIGUCCI JR, Davi. Minas, assombros e anedotas (os contos fantásticos de Murilo Rubião), In: Enigma e comentário - ensaios sobre literatura e experiência. São Paulo: Companhia das Letras, 1987, p. 146.
} 


\title{
4. A metamorfose técnica: o assombro grotescamente hiperbólico
}

A essas perguntas Davi Arrigucci Jr. tentou dar uma resposta em seus ensaios a respeito da obra de Murilo Rubião. Ele atenta para o caráter repetitivo e trágico das metamorfoses, que, ironicamente, nunca chegam a resvalar em mudanças efetivas para os personagens ou para as narrativas, encerrando-se em suas próprias e incansáveis multiplicações ${ }^{118}$ :

\begin{abstract}
Pequeno demiurgo encerrado no tédio e no desencanto, condenado à repetição infinita e estéril, o narrador observa, então, com fantasia assombrosa e humor gélido, às vezes com crueldade infantil, os tortuosos escaninhos da vida burocrática e do mundo administrado. É esse o espaço onde vivem seres sofridos e estagnados no ramerrão dos dias, não obstante as contínuas metamorfoses a que estão sujeitos. A metamorfose, motivo fantástico central a toda a obra, é uma das formas da ilusão, na medida em que, como a burocracia, parece existir apenas como multiplicação repetitiva dos meios. Na verdade, ela parece adquirir caráter metafórico, pois é ao mesmo tempo tema e procedimento, servindo de analogia especular ao falso movimento dos infinitos papéis burocráticos, multiplicados para paralisar, não para mudar o mundo. ${ }^{119}$
\end{abstract}

Segundo o crítico, a multiplicação das metamorfoses decorre de qualquer tentativa de movimentação da narrativa. Essa investida, no entanto, falha ao limitar-se à propagação dos seus próprios meios - ou seja, das figuras metamórficas - sem que atinja uma finalidade. A impossibilidade de alcançar objetivos satisfatórios e, consequentemente, a criação de um espetáculo ilusório que gira em torno de si mesmo fazem que a metamorfose abandone seu fundamento transformador e convertem-na em movimento corriqueiro e enfadonho, estabelecendo um paradoxo, pois deixa de se movimentar e culmina em paralisia: "Mesmice, repetição, monotonia constituem uma decorrência paradoxal desse modo de ser sempre em mudança" ${ }^{120}$. As mudanças convulsivas não causam, de fato, mudanças e são acompanhadas pela sua face antagônica: "A mesmice, ponto de retorno do movimento, é indício da unidade, mas foco de interrogações e perplexidades. Nos limites - princípio e fim - a multiplicação é roída pela ameaça da esterilidade" $" 121$.

A metamorfose, ademais, coloca-se como traço instituidor da índole dos seres metamorfoseados, que não conseguem fixar para si mesmos suas próprias identidades. No

\footnotetext{
${ }^{118}$ Arrigucci Jr. inspira-se, aqui, nas considerações feitas por Sartre a respeito da obra de Kafka e de Blanchot, em que a narrativa fantástica representaria o mundo reverso. Nesse universo: “O fantástico humano é a revolta dos meios contra os fins, seja que o objeto considerado se afirme ruidosamente como meio e nos mascare seu fim pela própria violência dessa afirmação, seja que ele remeta a um outro meio, este a um outro e assim por diante até o infinito, sem que jamais possamos descobrir o fim supremo, seja ainda que alguma interferência de meios pertencentes a séries independentes nos deixe entrever uma imagem compósita e embaralhada de fins contraditórios". Ver em: SARTRE, Jean-Paul. Animadab, ou o fantástico considerado como uma linguagem. In: Situações I - crítica literária. Trad. PRADO, Cristina. São Paulo: Cosac Naify. 2005. Pg. 140.

${ }^{119}$ ARRIGUCCI JR, Davi. O seqüestro da surpresa, In: Outros achados e perdidos. São Paulo: Companhia das Letras, 1999, pg. 307.

${ }_{120}$ _. Minas, assombros e anedotas (os contos fantásticos de Murilo Rubião), In: Op. cit. pg. 152.

${ }^{121}$ Idem, ibidem.
} 
círculo entediante de transformações, comenta Arrigucci, onde elas se dobram para o seu próprio rodopio, ou seja, para a sua própria ruína e esterilidade, não parece haver vislumbre para experiências transcendentais, diferentemente do que encontramos na obra de Kafka, em que elas estão presentes, conquanto inacessíveis:

\begin{abstract}
A multiplicação sem fim, metamorfose última do próprio universo, é uma ideia dissolvente, com seu horror do infinito. Murilo parece exorcizar essa eternidade em vida, na experiência objetivadora de seus contos. Estes apontam para o rodopio incessante e parecem descartar toda transcendência, diferentemente do caso de Kafka, onde ela está presente, sem que se possa atingi-la. Aqui a imensa roda da fortuna remói sobre si mesma, espalhando o temor da esterilidade sem termo. A pluralidade de nomes e de seres instáveis carrega consigo, todo o tempo, a dúvida quanto à identidade do ser, questão funda de angústia e perplexidade. Na rotina estéril, apenas o sonho (nem mesmo o amor) volta com seu aceno de impossibilidades. ${ }^{122}$
\end{abstract}

Ora, a figura do círculo que se autodestrói devido ao seu movimento repetitivo e infindo remete, justamente, à figura do monstro lendário Uroboro, do qual Jorge Schwartz serviu-se para metaforizar a obra de Murilo Rubião. Segundo o crítico, o homem-uroboro define-se como aquele que, submetendo-se continuamente a um processo de tentativas de ajustamento ao seu contexto, sempre é levado ao desajustamento. A impossibilidade de comunicar-se com o seu contexto faz do herói muriliano um estranho diante dos outros e diante de si mesmo, condenando-o ao desterro. Schwartz enxerga nas metamorfoses as diversas tentativas desse homem exilado de alcançar uma identificação e um reconhecimento, por isso o aspecto redundante de suas transformações, contudo: “As metamorfoses e as mágicas também perdem o sentido na medida em que se repetem. Assim, o traço 'estranho' acaba sendo devorado pelo traço 'automatizado""123.

O crítico conclui que as metamorfoses deixam de se opor ao mundo ordinário do herói muriliano e transformam-se em figuras análogas a ele, reiterando-se num movimento de sobreposição. O homem-uroboro, portanto, não se crê suficientemente hábil para quebrar o automatismo da sua realidade - mesmo com as metamorfoses mais absurdas -, e, como já anunciava Arrigucci, está fadado à paralisia.

Em todos os termos que Arrigucci usa para referir-se aos procedimentos sobrenaturais, como "a multiplicação repetitiva dos meios" e "rodopio incessante", nota-se que uma das particularidades do fantástico em Murilo Rubião, sobretudo no desenvolvimento do tema metamórfico e de seus procedimentos, está na sua retórica hiperbólica. Todas as expressões usadas pelo crítico tentam exprimir a tendência ao infinito e ao incontrolável encontrada na obra do escritor. Se o seu estilo está marcado por sua sobriedade e por seu casticismo, o mesmo

\footnotetext{
122 Idem, ibidem. pg. 164.

${ }^{123}$ SCHWARTZ, Jorge. Op. cit. pg. 51
} 
não pode ser dito das imagens insólitas que ele constrói. Se comparado, como já realizamos anteriormente, a outros escritores que também contribuíram à literatura fantástica contemporânea do autor mineiro, seu manejo das figuras hiperbólicas salta ainda mais aos olhos.

Schwartz também chama a atenção para a presença da hipérbole no discurso narrativo de Murilo Rubião, uma vez que "a hipérbole se manifesta na poética de MR como figura-chave que desvenda os mecanismos fantásticos da narrativa" ${ }^{124}$. Ao descrever os movimentos hiperbólicos presentes nos contos, o crítico afirma que o leitor se depara com duas modalidades distintas - a auxesis e a tapinosis. Esta seria a diminuição que tende ao completo desaparecimento, como encontramos no conto $O$ homem do boné cinzento, e aquela seria o aumento indeterminado, como a do conto Bárbara $^{125}$. Ambas as modalidades são extremamente deformadoras e alcançam os limites do irreconhecível das formas corporais, espaciais e temporais. No conto $O$ edifício, por exemplo, vemos a construção de um arranha-céus que nunca para de aumentar, ganhando a cada dia mais e mais andares. Em A armadilha, o encontro entre o protagonista e o alvo de sua busca será prolongado, como está anunciado no desfecho, pelos próximos milhares de anos.

Vale lembrar que, em alguns contos, as duas modalidades hiperbólicas acontecem simultaneamente e estabelecem um jogo de oposições. Em Bárbara, por exemplo, há o antagonismo entre a figura prodigiosa da heroína e o corpo mirrado e incapaz de se desenvolver do seu filho. O mesmo acontece com Teleco, mas dentro dos limites do seu próprio corpo. Afinal, o personagem passa do corpo de um pequeno animalzinho às formas mais bestiais, inclusive a algumas inexistentes, culminando na figura esquálida e suja de uma criança morta.

Tal efeito hiperbólico de Rubião intensifica-se, conforme Schwartz, pelo processo de reiteração: “A hipérbole, como figura de retórica por excelência na poética do Autor, apoia-se na repetição para sua formalização no discurso" ${ }^{126}$. O crítico acerta ao apontar esses dois eixos como as principais forças que sustentam as diferentes metamorfoses do texto. A sucessão exaustiva, hiperbólica e reiterada de imagens transfiguradas mostra-se, com efeito, crucial para alguns contos do nosso autor - está presente nos encantamentos do ex-mágico; na pirotecnia de Zacarias; nas metamorfoses de Teleco e de Alfredo; no revezamento de corpo e de identidade

\footnotetext{
${ }^{124}$ Idem, ibidem.

${ }^{125}$ Como o próprio crítico faz referência, as duas modalidades hiperbólicas usadas por ele foram tiradas, mais uma vez, dos estudos de Roland Barthes. Ver em: BARTHES, Roland. L'ancienne, rhétorique/aide-mémoire. Recherches rhétoriques. In: Communications. Paris: Seuil, 11, 1968.

${ }^{126}$ SCHWARTZ, Jorge. Op. cit. pg. 73
} 
das esposas de Godofredo; no nascimento e na multiplicação dos bebês de Aglaia; entre outros exemplos.

A partir daí, Schwartz ratifica aquilo que Arrigucci já havia dito sobre o caráter das metamorfoses de Murilo Rubião, afirmando que elas podem ser meros meios que nunca alcançam um objetivo, um fim concreto. Ele, no entanto, dá uma definição mais conceitual da figura hiperbólica reiterada, sem limitá-la ao papel metafórico de burocratização do universo do herói muriliano, indicando qual o seu uso mais frequente na ficção literária e a sua especificidade dentro da obra do escritor. Para isso, ele estabelece um paralelo entre a função do discurso reiterado na retórica tradicional e no trabalho poético:

No caso da retórica tradicional, a figura é um modo de chegar ao receptor e reconfirmar os seus sistemas de expectativas. É uma técnica suasória que se adapta à história de quem recebe a mensagem. Já na leitura poética acontece o contrário, e, atribuindo à ficção uma dimensão poética, a figura teria por função criar uma ruptura no sistema de expectativas do leitor. O que acontece, então, quando os desvios da obra criam um sistema de redundâncias retóricas, como é o nosso caso? Justamente, a noção de absurdo em Murilo Rubião, para a qual convergem técnicas e temas narrativos, é fruto de um equilíbrio constante constituído por um desequilíbrio inicial, que leva ao non sense, numa destituição da significação, num esvaziamento de conteúdos. Se por um lado a hipérbole é um modo inicial de ruptura, por outro conduz, pelo próprio processo de redundância, à noção de ausência, para a qual se encaminha a estrutura da obra. ${ }^{127}$

A redundância do estilo e das figuras sobrenaturais do nosso autor inverte, portanto, a função retórica tradicionalmente atribuída à hipérbole e à reiteração, de confirmadoras das expectativas, para esvaziar o sentido dos eventos sobrenaturais e compor uma narração fundada sob a noção da ausência. Nessas considerações acerca da estrutura da obra fantástica muriliana, Schwartz revela um procedimento bastante comum para a criação literária do nonsense no uso redundante sobretudo das metamorfoses. Se, no início, elas servem como a ruptura sobrenatural que chacoalha o mundo de referencial empírico da narrativa, elas tendem a naturalizar-se conforme seu uso aumenta, como acontece na narrativa de Kafka, de Cortázar e de Borges, deixando de espantar tanto os personagens quanto o leitor.

No entanto, por serem utilizadas exaustivamente como recursos técnicos e retóricos e por apoiarem-se sobre um discurso hiperbólico e reiterado, as metamorfoses em Murilo Rubião não apenas se naturalizam como também são dissolvidas de seu sentido, de sua significação, acrescentando à narrativa uma impressão demasiadamente abstrata e opaca, que tende ao absurdo. Esse percurso também já havia sido notado por Eliane Zagury, que delimita o caminho da narrativa muriliana num esquema de três passos: "constatada determinada relação absurda na vida, cria-se uma situação absurda simbólica (a situação ficcional) que desencadeia uma

\footnotetext{
${ }^{127}$ Idem, ibidem. pp. 74-75.
} 
série de absurdos técnicos (ou de efeito literário) que se desenvolvem até o absurdo final (a solução ficcional) que traz o leitor de volta para o tema"128. Seguindo esse esquema, as metamorfoses tanto fariam parte do primeiro passo, concebendo-se como a situação absurda primordial, quanto fariam parte do segundo passo do esquema de Zagury, relegadas à categoria de absurdos técnicos responsáveis pelo efeito literário dos contos, repetindo-se extenuantemente até perderem sua significação própria.

A ocorrência da metamorfose muriliana passaria, dessa forma, de conflito da narrativa à ornamentação técnica do absurdo. Em Teleco, o coelhinho, a transfiguração do animalzinho em outras criaturas dá-se de maneira tão veloz, hiperbólica e reiterada que, como afirma Zagury, "o absurdo técnico da metamorfose tem a movimentação de um desenho animado cômico" " Esse absurdo técnico também estaria presente, segundo a crítica, nos passes de mágica do exmágico da Taberna Minhota.

Deparamo-nos, mais uma vez, com as diferenças profundas entre essas figuras metamórficas e aquelas encontradas em Kafka e Lautréamont. Se, em Rubião, as metamorfoses podem ser descritas como "meios sem finalidade" ou "absurdos técnicos", o mesmo não se aplica aos outros dois escritores. Em A metamorfose, por exemplo, a transformação de Samsa em inseto é experimentada até o final em todas as funções e disfunções desse corpo estranho. As metamorfoses de Maldoror, por sua vez, apesar de também serem velozes, nunca são gratuitas ou aleatórias e sempre respondem a uma vontade íntima do personagem e que corresponde aos seus estados febris de excitação e de desejo por violência.

Todavia, em Murilo Rubião, a distância estabelecida entre a metamorfose, o narrador e o tempo da narração, além do discurso hiperbólico e reiterado, exaurem a força do processo transfigurador e o transforma em técnica. A correlação entre esse tipo de discurso notado por Schwartz e Zagury, marcado pelo exagero e pelo excesso, e o seu esvaziamento e consequente efeito absurdo também está presente nos comentários da Retórica geral a respeito de tais metalogismos. Seus autores ressaltam a tendência estética de distanciamento do uso da hipérbole ou da reiteração (no caso, repetição): “Como o pleonasmo e a hipérbole, a repetição pode 'engordar' o evento, 'aumentar' as coisas [...] mas assinala, antes de tudo, a distância assumida em relação ao referente, que é tratado como uma soma de unidades ontológicas à qual a linguagem empresta unidades suplementares" ${ }^{130}$. O metalogismo, que tem por função fazer

\footnotetext{
${ }^{128}$ ZAGURY, Eliane. Murilo Rubião, o contista do absurdo. In: A palavra e os ecos. Petrópolis: Editora Vozes, 1971, pp. 28-29.

${ }^{129}$ Idem, ibidem. pp. 32-33.

${ }^{130}$ DUBOIS, Jacques et alii. Retórica geral. Trad. MOISÉS, Carlos Felipe et alii. São Paulo: Cultrix/Edusp, 1970, pg. 192.
} 
desvios no discurso sem alterar o sentido do léxico, ou seja, sem fazer alterações próprias de um tropo ou figura, encontra na sua forma hiperbólica ou reiterada uma das maneiras mais competentes de afastamento de um conceito, ou referente, e caminha, como afirma Schwartz, para o esvaziamento de todo conteúdo.

Um exemplo de tal esvaziamento notamos no conto Aglaia. Nele, acompanhamos a história em flashback de um homem cuja vida foi arruinada pelos partos inexplicáveis e descontrolados de sua antiga esposa, que lhes rendiam proles cada vez mais numerosas. Colebra, que no início da narrativa já vive longe de Aglaia e consome bebidas alcoólicas desregradamente, acorda sufocado pelos excrementos dos seus próprios filhos, que deitaram em cima de seu corpo enquanto ele estava inconsciente após uma bebedeira. A partir daí a narrativa volta para fatos mais antigos e assistimos ao encontro e, posteriormente, ao casamento dos dois personagens, motivado pelo interesse financeiro de Colebra. Os dois não desejavam ter filhos, o que deixava o marido ainda mais satisfeito, uma vez que o corpo da mulher nunca seria deformado. Após uma gravidez indesejada e um aborto mal realizado que perfurou seu útero, deixando-a à beira da morte e, segundo os médicos, estéril, Aglaia passa por uma longa convalescença que, imprevisivelmente, resulta numa nova gravidez.

Nenhum método contraceptivo parece estar apto a impedir que Aglaia engravide novamente, fazendo que suas gestações aconteçam ininterruptamente e em intervalos cada vez menores:

\begin{abstract}
Desencadeara o processo e de súbito o nascimento dos filhos não obedecia ao período convencional, a gestação encurtava-se velozmente. Nasciam com seis, três, dois meses e até vinte dias após a fecundação. Jamais vinham sozinhos, mas em ninhadas de quatro ou cinco. Do tamanho de uma cobaia, cresciam com rapidez, logo atingindo o desenvolvimento dos meninos normais. Não se prendiam ao corpo materno pelo cordão umbilical. Essa circunstância facilitava o parto, sem que amenizasse as dores e fossem menores os incômodos da gravidez. ${ }^{131}$
\end{abstract}

Os sofrimentos de Aglaia, a quem Paes chama de "Eva hiperbólica condenada a uma horrível e grotesca fertilidade que a faz parir filhos às ninhadas, com rapidez de cobaia"132, levam-na a desejar o divórcio, que não é prontamente aceito por Colebra, pois ele desejava aumentar, com o tempo, o acordo de ajuda financeira que receberia. Os meninos raquíticos e endiabrados, no entanto, levam o casamento a tamanho desgaste que Colebra muda de ideia e abandona Aglaia, motivado sobretudo pelo nascimento de meninas metamorfoseadas em autômatos, cujos rostos assombrosos chamam a atenção de Arrigucci: "as últimas filhas de

\footnotetext{
${ }^{131}$ RUBIÃO, Murilo. Aglaia. In: Op. cit. pg. 195.
}

132 PAES, José Paulo. Op. cit. pg. 119. 
Aglaia, antes da fuga do marido, têm olhos de vidro, lembrando os bonecos maquinais e grotescos de E. T. A. Hoffmann"133.

Notemos que ambos os críticos fizeram uso do adjetivo grotesco para referirem-se às impressões diante do efeito insólito produzido pelo conto Aglaia. Para Paes, a fertilidade de Aglaia que se encaixa nessa descrição, já para Arrigucci o aspecto maquinal das últimas crianças a nascer que se desenvolve grotescamente. $\mathrm{O}$ termo coincidente nos leva a crer que ele não foi aplicado ao acaso pelos dois, mas, sim, como a única maneira de nomear a camada estética dessa narrativa, cujas linhas de força são, precisamente, as imagens por eles evocadas e ressaltadas - os partos desenfreados e as meninas robóticas.

Com efeito, quer Arrigucci, quer Paes levantam temas e representações tradicionalmente caras às concepções estéticas do grotesco na arte. Mikhail Bakhtin, em seu estudo acerca da obra de François Rabelais, já designava a imagem conjunta do parto de Gargamelle, do incomensurável banquete que o acompanhou e do consequente nascimento do herói Gargantua como aquela que inaugura a construção grotesca do universo pantagruélico, marcado pela fartura e pela incessante e hiperbólica multiplicação de seus componentes: "O motivo dominante desse extrato é a generosa abundância material e corporal, que vem ao mundo e cresce. Todas as imagens lhe estão subordinadas"134. Essa representação do baixo corporal por meio de um parto e seu uso como pedra fundamental para o resto da obra revelase bastante significativa para percebermos a importância de tal imagem para a estética grotesca, em que o ventre, as entranhas e os intestinos são "as imagens capitais, primordiais de todo o episódio"135 que já adiantam o mundo carnavalesco, que resvala a sensação abjeta ${ }^{136}$, de Rabelais.

\footnotetext{
${ }^{133}$ ARRIGUCCI JR, Davi. Minas, assombros e anedotas (os contos fantásticos de Murilo Rubião), In: Op. cit. pg. 159.

${ }^{134}$ BAKHTIN, Mikhail. A cultura popular na Idade Média e no Renascimento: o contexto de François Rabelais. Trad. VIEIRA, Yara Frateschi. 6. ed. São Paulo: Hucitec; Brasília: Editora Universidade de Brasília, 2008, pg. 192.

135 Idem, ibidem.

136 Apesar do ato de dar à luz e das outras imagens ligadas ao baixo corporal serem, como justifica Bakhtin, brincadeiras correntes nos festins medievais e renascentistas, e, portanto, nada surpreendentes para os contemporâneos a Rabelais, com o passar do tempo, ainda segundo o crítico, elas serão recepcionadas de maneira diversa por seus novos leitores, cujos olhos passam a encher-se de repugnância, fazendo que os retratos rabelaisianos já não encontrem mais o mesmo acolhimento que receberam à época de sua publicação. Isso explicaria o fato de Julia Kristeva, em seus estudos a respeito do horror, não mais ver o aspecto carnavalesco do parto e das imagens do baixo corporal e ressaltar somente o seu viés horripilante, responsável pelo surgimento da sensação abjeta. Kristeva estabelece, por sua vez, relações entre a abjeção e o corpo maternal, que estaria na origem da erotização do abjeto pelo homem. Esse corpo ao mesmo tempo desejável a apavorante, fascinante e abjeto, que expele sua cria como um dejeto, como uma excreção a ser eliminada. Ver em: KRISTEVA, Julia. Pouvoirs de l’horreur : essai sur l'abjection. Paris: Éditions du Seuil, 1986, pp. 66-67.
} 
Embora esse assunto tenha uma extensa fortuna crítica e seu aprofundamento demande estudos mais demorados, a hipérbole muriliana está intimamente relacionada com a estética grotesca e, por isso, tal aproximação faz-se necessária. Dessa maneira, precisamos destrinçar sua gênese e sua evolução artística a fim de compreendermos a relação estabelecida entre a estética e os temas grotescos e as metamorfoses dos contos de nosso autor ${ }^{137}$.

Wolfgang Kayser, ao detalhar o aparecimento da arte grotesca na Europa no final do século $\mathrm{XV}$, quando se descobriu um tipo de ornamentação diferente realizada pelos antigos cujo nome vem, precisamente, por ter sido encontrada em escavações de grutas em algumas regiões da Itália - relata o incômodo dos artistas renascentistas, habituados a pintarem segundo o modelo anatômico vitruviano, ou seja, buscando a perfeição das formas humanas, ao se defrontarem com tamanha confusão de formas:

Na palavra grottesco, como designação de uma determinada arte ornamental,
estimulada pela Antiguidade, havia para a Renascença não apenas algo lúdico e alegre,
leve e fantasioso, mas, concomitantemente, algo angustiante e sinistro em face de um
mundo em que as ordenações de nossa realidade estavam suspensas, ou seja: a clara
separação entre os domínios e os utensílios, das plantas, dos animais e dos homens,
bem como da estática, da simetria, da ordem natural das grandezas. O fato se
manifesta na segunda designação que surgiu para o grotesco no século XVI: sogni dei
pittori. Com ele se indica ao mesmo tempo o domínio em que a ruptura de qualquer
ordenação, a participação de um mundo diferente, tal como aparece sensivelmente na
ornamêntica grotesca, se torna para todo ser humano uma vivência, sobre cujo teor de
realidade e verdade o pensar jamais alcançou bom termo. ${ }^{138}$

O uso do termo grotesco, ainda segundo Kayser, foi ampliado ao longo do tempo e sua presença passou a ser percebida, pouco a pouco, na literatura. Sua utilização como ornamento plástico também foi alterada, ganhando campos onde não havia qualquer preponderância do

\footnotetext{
${ }^{137}$ Um exemplo desse humor grotesco degenerado seria o conto $O$ nariz, de Nicolai Gógol. Ambientada na São Petersburgo do século XIX, a narrativa do escritor russo ri da realidade comezinha das instituições públicas, ou seja, satiriza a oficialidade e a pompa da capital do império a partir da história absurda do nariz de um major que ganha vida e passa a andar pelas ruas da cidade, como seu duplo, enquanto o militar persegue-o desesperadamente. Embora o traço cômico seja evidente, Gógol não deixa de despertar estranheza em seu leitor, exatamente pelo choque entre o nariz que ganha vida e o rosto plano do major com a frivolidade da vida petersburguense, explica Arlete Cavaliere: "Com efeito, o cunho grotesco desse conto, em particular, mesmo que atenuado pelo seu caráter lúdico e satírico, não deixa de lhe conferir um estatuto fortemente atual. A busca absurda e desesperada do major Kovalióv que corre sem nariz por toda São Petersburgo com seu rosto ridículo e excêntrico, "plano como uma panqueca"; as atitudes mais inusitadas e inesperadas como, por exemplo, a tentativa de publicar no jornal a fuga do próprio nariz e oferecer uma gratificação para aquele que informasse o seu paradeiro; sem contar os diversos diálogos "fantásticos" entre as mais diversas personagens (inclusive o próprio nariz) durante a busca incessante, acabam por produzir, através de um abrochar irracional, um mundo irreal de personagens e ocorrências estranhas. Tudo perde o seu aspecto familiar e a desproporção no miúdo sugere uma desarmonia universal. O homem se reduz a um autômato movido por forças misteriosas. [...] É dessa desorientação em face de uma realidade tornada enigmática e insondável que decorre a reação de horror, espanto, nojo e mesmo riso arrepiado das personagens, do leitor e do próprio narrador, que no caso de Gógol, embora através de uma narrativa irônica e satírica, deixa transparecer um ligeiro estremecimento ante o espetáculo descomunal de um mundo cujas categorias básicas perdem a sua validade". In: CAVALIERE, Arlete. A magia das máscaras. In: GÓGOL, Nicolai. $O$ nariz \& $A$ terrível vingança. Trad. CAVALIERE, Arlete. São Paulo: Edusp, 1990, pp. 110-111.

${ }^{138}$ KAYSER, Wolfgang. O grotesco: configuração na pintura e na literatura. Trad. GUINSBURG, Jacó. São Paulo: Editora Perspectiva, 1986, pg. 20.
} 
belo e apenas a busca pela desproporção, como a caricatura. Contudo, na mesma medida em que a estética grotesca aproxima-se do humor, ela também se avizinha aos sentimentos macabros, mórbidos e abjetos, fazendo despertarem efeitos divergentes: "Várias sensações, evidentemente contraditórias, são suscitadas: um sorriso sobre as deformidades, um asco ante o horripilante e o monstruoso em si" ${ }^{139}$. O caráter originalmente ornamental da expressão grotesca do belo, presente em arabescos e mouriscos, cede, pouco a pouco, a outras urgências artísticas, mas preserva sua estética de deformação.

Bakhtin, ao enxergar o lado cômico, aproxima a estética grotesca das figuras desproporcionais e hiperbólicas do texto rabelaisiano, retrato descomunal dos festivais e das feiras populares de sua época. Afinal, essa visão carnavalesca do mundo, “oposta a toda ideia de acabamento e perfeição, a toda pretensão de imutabilidade e eternidade, necessitava manifestar-se através de formas de expressão dinâmicas e mutáveis (proteicas), flutuantes e ativas" 140 .

Não por acaso, será no teatro popular onde essa manifestação artística também adquirirá grande força. As apresentações paramentadas da commedia dell'arte fundam uma tradição expressivamente grotesco-cômica, não muito pelos textos representados, mas, sim, pela movimentação dos atores no palco, onde as máscaras "servem de meio para aplicar aos corpos humanos algo de animalesco" com suas feições distorcidas e suas extremidades pontiagudas ${ }^{141}$.

A face horripilante e sombria da estética grotesca foi, por sua vez, trabalhada copiosamente ao longo dos séculos XVIII e XIX pelo Sturm und Drang e, posteriormente, por todas as manifestações românticas que tomaram conta da Europa, como uma reação aos ideais iluministas e a suas formas artísticas contidas e racionais. Nesse contexto, Hoffmann foi mestre em criar cenas grotescas. Ainda influenciado pelo jogo de máscaras e disfarces teatrais característicos da commedia dell'arte e das festas carnavalescas - que passa a mostrar as suas piores feições e suas caretas mais assustadoras -, o autor inova ao fazer o sinistro do mundo despontar de uma narrativa aparentemente fiel à realidade circundante. No entanto, para Kayser, a explicação dessas passagens sinistras ainda está, na prosa do escritor alemão, muito ligada às forças sobrenaturais e aos poderes terríficos de uma mitologia infernal. Partindo da mesma lógica, Victor Hugo oporá o conceito de grotesco ao de sublime, dando ao primeiro deles maior profundidade, segundo Kayser: "Pois, assim como o sublime - à diferença do belo - dirige o nosso olhar para um mundo mais elevado, sobre-humano, do mesmo modo abre-se no ridículo-

\footnotetext{
${ }^{139}$ Idem, ibidem. pg. 30.

${ }^{140}$ BAKHTIN, Mikhail. Op. cit. pg. 9.

${ }^{141}$ KAYSER, Wolfgang. Op. cit. pg. 43
} 
disforme e no monstruoso-horrível do grotesco um mundo desumano do noturno e abismal" ${ }^{\text {"142 }}$. É apenas nesse momento, portanto, que o grotesco deixa de servir preponderantemente como ornamentação ou máscara e torna-se ferramenta de questionamento e de observação do mundo.

A literatura fantástica deste momento, muito influenciada pela prosa de Hoffmann, aproximará os temas caros à estética grotesca aos motivos usados por esses escritores para criar o medo e a hesitação ante o sobrenatural. Como observa David Roas, o fantástico e o grotesco compartilham muitos temas nas suas narrativas, entre eles a metamorfose, e ressalta "o uso peculiar que se faz nas obras grotescas de temas e recursos típicos da literatura fantástica, ligados indefectivelmente em tal gênero ao medo e ao sinistro (o duplo, a aparição fantasmagórica, a metamorfose, a animação de objetos...) "143. No entanto, ainda segundo Roas, a literatura fantástica não se apropriou dos temas grotescos senão a partir de seu viés horripilante. $\mathrm{O}$ que distingue a obra genuinamente grotesca dessa outra literatura é a sua tendência para imagens hiperbólicas e deformatórias, capazes de misturar o riso com a sensação do pavor, dado que a distância estética é dilatada ao anular o sentimento de empatia, como encontramos em Murilo Rubião.

Por conta dessa propensão, aquilo que deveria provocar no leitor apenas inquietação e horror também o leva ao alívio cômico:

\begin{abstract}
Os textos grotescos que utilizam elementos sobrenaturais (impossíveis) vão além da criação de uma impressão fantástica, uma vez que a hipérbole e a deformação que os caracterizam conduzem a narrativa para outro efeito: nem o narrador pretende que o leitor aceite o acontecimento sobrenatural narrado, nem o leitor o consome pensando em sua possibilidade efetiva. Trata-se, em última instância, de deformar os limites do real, de levá-los à caricatura, não para produzir a inquietude própria do fantástico, mas para provocar o riso do leitor, ao mesmo tempo em que o impressiona negativamente com o caráter monstruoso, macabro, sinistro ou simplesmente repugnante dos seres e das situações representadas, sempre - a meu ver - com o objetivo essencial de revelar o absurdo e o sem-sentido do mundo e do eu. Em um e outro âmbito - emissor e receptor -, o riso estabelece o que poderíamos chamar de "distância de segurança" diante do sobrenatural, que desvirtua o possível efeito fantástico da obra. ${ }^{144}$
\end{abstract}

Tal diferença pode ser observada, por exemplo, na comparação dos efeitos produzidos pelos contos $O$ homem da areia de Hoffmann e Aglaia de Rubião. No primeiro, a revelação da real identidade de Olímpia causa transtornos psíquicos irreversíveis no herói Natanael e o conduz ao suicídio, despertando no leitor, segundo Freud ${ }^{145}$, o efeito inquietante daquilo que

\footnotetext{
${ }^{142}$ Idem, ibidem. pg. 60.

${ }^{143}$ ROAS, David. A ameaça do fantástico: aproximações teóricas. Trad. FUKS, Julián. São Paulo: Editora Unesp, 2014, pg. 197.

${ }^{144}$ Idem, ibidem. pp. 198-199.

${ }^{145}$ FREUD, Sigmund. O “estranho”. In: Obras psicológicas completas de Sigmund Freud; Volume XVII (19171919). Trad. SOUZA, Eudoro Augusto Macieira de. Rio de Janeiro: Imago Editora, 1976.
} 
nos aparenta estranhamente familiar ${ }^{146}$. Já no segundo conto, as consequências mesquinhas e nada terrificantes produzidas pelas filhas de olhos de vidro - a aceitação do divórcio e a posterior vida desregrada de Colebra -, além da própria postura do protagonista que, diante dos partos incontroláveis de Aglaia, preocupa-se apenas com o dinheiro que pode ganhar da esposa, produzem, com efeito, a sensação de pavor cômico descrita por Roas. Nas palavras de Arrigucci, o conto Aglaia pode ser lido como a "glosa irônica do mito de Adão e Eva"147.

Seja por meio do riso seja por meio do horror, a imagem grotesca, aponta Bakhtin, distanciou-se cada vez mais de seu polo positivo, escatológico, festivo e burlesco, momento de comunhão com as forças terrestres, com o baixo material e corporal e de sua força regeneradora para aproximar-se do polo negativo da degradação e da destruição. Isso explicaria o seu uso depreciador e sarcástico nas sátiras e, por outro lado, funesto e sombrio na literatura séria. $\mathrm{O}$ grotesco, preso a um contexto cada vez mais burocrático e mecanizado, desponta como a suspensão das leis e das normas de um mundo enfadonhamente padronizado, servindo, em muitos casos, como crítica a essa conjuntura social. A criação de imagens ligadas ao baixo material e corporal - às quais Bakhtin atribui a gênese da estética grotesca - não deixam de figurar nessas novas obras, mas sempre, segundo o crítico, guiadas unicamente pela intenção de suspender as regras de uma realidade protocolar.

A atração pelo polo negativo do grotesco parece, entretanto, ter sido positivamente proveitosa para os movimentos artísticos do século XX. Como explicita Anatol Rosenfeld, ao salientar o reaparecimento do grotesco nos Novecentos, afirma que: "A arte e a literatura grotescas, à semelhança das criações do maneirismo, tornaram-se no nosso século objeto de uma valorização extremamente positiva"148. De alguma maneira, a estética grotesca foi retomada como importante meio de expressão literária para os escritores novecentistas, justamente por suspender os limites da realidade circundante a fim de expor, ironicamente, as regras bizarras que regem esse mundo. Todavia do humor folgazão do grotesco carnavalesco

\footnotetext{
${ }^{146}$ Eliane Robert Moraes salienta que o efeito do conto $O$ homem da areia parte do medo que todos os habitantes da cidade de Natanael sentiram após o fim funesto do jovem - o de também serem enganados por um autômato. Esse pavor coletivo leva a cidade a um clima de histeria, em que cada pessoa exige da outra uma prova de sua humanidade: "É precisamente dessa indagação sobre a realidade da figura humana que decorre grande parte do efeito sinistro do conto. O insuportável, no caso de $O$ homem da areia, não reside na descoberta de que Olímpia é um autômato, mas sim no fato de Natanael acreditar, sem qualquer hesitação, que ela seja um ser vivo. Apesar da suspeita dos amigos, a quem os passos de Olímpia pareciam 'estranhamente compassados' e seus movimentos 'condicionados por um mecanismo de relojoaria', em nenhum momento o jovem enamorado interroga a realidade do objeto de sua paixão. [...] A questão fundamental do conto de Hoffmann não parece residir, portanto, na desconfiança em relação ao autômato: à exceção do jovem apaixonado, todos compartilhavam um certo receio de que Olímpia fosse, na verdade, uma boneca animada". In: MORAES, Eliane Robert. Op. cit. pg. 94.

${ }^{147}$ ARRIGUCCI JR. Davi. Minas, assombros e anedotas (os contos fantásticos de Murilo Rubião), In: Op. cit. pg. 160.

${ }^{148}$ ROSENFELD, Anatol. A visão grotesca. In: Texto/contexto I. Op. cit. pg. 59.
} 
não resta senão uma visão ressentidamente irônica do mundo nessas novas manifestações artísticas.

Hiperbólica e deformatória, a prosa de Murilo Rubião insere-se, pontualmente, na nova concepção do grotesco literário. Como afirma Arrigucci, na obra muriliana "uma feição grotesca se expande no rosto do mundo, acentuada pelos seres que aí habitam, caracterizados, em virtude da metamorfose, pela mescla entre os reinos humano, animal e vegetal" ${ }^{\prime 149}$. Essa outra feição do mundo, segundo o crítico, também seria aquela das velhas histórias grotescas do anedotário das cidadezinhas provincianas de Minas Gerais: "A habilidade para deformar historietas tradicionais, como meio de inventar a forma nova, está no centro da técnica ficcional de Murilo, desde o manejo da linguagem até a construção do enredo". ${ }^{150}$

A camada grotesca da prosa muriliana seria, portanto, referência a um universo de narrativas que perde seu lugar e que, segundo a lógica de Bakhtin, só deixa, com o passar do tempo, sua face mais nefasta. Mais ainda, por continuar a defender-se de seu fim, a união desse domínio das antigas histórias com a nova realidade que ocupou seu espaço dá origem a uma existência asfixiante. Afinal, a ausência de comunhão com o mundo antigo e a consequente pulverização da alegria grotesca dá origem a uma ironia amarga, única reação diante de uma realidade, em si, muito mais estranha que as metamorfoses, a pirotecnia e os feitiços dos contos murilianos. Como no mundo encantado e desencantado do ex-mágico, a magia, resistente, como dissemos, ao desterro, torna-se sempre um empecilho para as regras que devem funcionar e serem seguidas no mundo normatizado. Além disso, ao se transformar numa regra - e deixar de lado sua força de ruptura com o cotidiano - ela passa a ser rotina igualmente enfadonha para o herói.

O mundo grotesco criado por Rubião, portanto, não pode existir, devendo ser sufocado para não atrapalhar o passeio público e para não pôr em risco a integridade física dos cidadãos. Ao resgatar diversos temas, formas, figuras e máscaras da estética grotesca, Murilo Rubião parece construir tão-somente os arabescos e mouriscos descritos por Kayser que serviam de ornamentação para os antigos. No entanto - como Kafka e outros escritores - nosso autor impõe a estética da deformação como máscara para ocultar a face desfigurada daquilo que ele pretende, justamente, revelar.

\footnotetext{
${ }^{149}$ ARRIGUCCI JR. Davi. Minas, assombros e anedotas (os contos fantásticos de Murilo Rubião), In: Op. cit. pg. 156. 150 O sequestro da surpresa. In: Op. cit. pg. 308. Grifo do autor.
} 


\section{A ironia}

A distorção discursiva do uso da hipérbole também possui outros efeitos para o texto, resultantes de sua artificialidade técnica, do seu afastamento do referente e, portanto, da lonjura que ele estabelece com a verossimilhança, ainda mais por sua proximidade com a comunicação coloquial, marcadamente oral ${ }^{151}$. Vejamos esta definição encontrada num dicionário de retórica e de terminologia literária:

Figura lógica que consiste en emplear palabras exageradas para expresar una idea que está más allá de los límites de la verosimilitud. [...] En general, se puede decir que la hipérbole tiene un significado enfático, y de aquí el uso - y aun abuso - que de ella se hizo en el Barroco. [...] Frecuentemente la hipérbole adquiere un sentido cómico, que patentiza la desproporción entre las palabras y la realidad [...] o la distanciación irónica con que el autor describe algunos hechos. ${ }^{152}$

A desproporção entre a palavra e a realidade, entre o narrador e o referente, entre o autor e os acontecimentos é propiciatória, portanto, para o discurso cômico, satírico ou irônico. As metamorfoses em Murilo Rubião, por mais trágicas e degradantes que possam ser suas consequências para os personagens, costumam ser acompanhadas pelo riso. Por fazerem parte de um espetáculo apenas testemunhado pelo leitor e rememorado pelo narrador, tal distância permite que os acontecimentos hiperbólicos, de tão reiterados e absurdos, suavizem seu aspecto trágico e façam sobressair os elementos cômicos.

No entanto, mesmo a segurança da distância atual entre o narrador e a narrativa não elimina completamente o ângulo trágico do conto, uma vez que é a sua própria história que está sendo recordada e narrada. A mistura entre a distância dos fatos sobrenaturais e a amargura com que os protagonistas se lembram de suas próprias histórias cria um discurso notadamente irônico e, como afirma Arrigucci, de forte tradição machadiana:

A tradição que vem de Machado de Assis certamente é decisiva na formação de Murilo e está muito presente em suas tiradas irônicas. Mas aqui o narrador não se situa em Sirius ou no além-túmulo. Quer dizer: a ironia não é essencialmente produto de um narrador situado a uma tal distância, que seja capaz de relativizar tudo. No caso, ela inclui também o narrador e seu ponto de vista: este sonha acordado e, embora

\footnotetext{
${ }^{151}$ Pierre Fontanier ressalta a fragilidade da hipérbole para garantir o efeito de verossimilhança no discurso, acusando-a de, por ser muito próxima da linguagem oral (que, segundo o autor, é bastante hiperbólica), ser usada como estratégia de persuasão. Embora o estudioso francês não dê um termômetro capaz de medir quando a hipérbole fantasia ou não um texto, ele ressalta a importância da participação do leitor para que o efeito hiperbólico alcance seu fim, seja fantasioso, seja verossímil: «Les mots, considérés en eux-mêmes et dans tous les rapports grammaticaux, y peuvent conserver leur significations propre et littérale, et 's'ils ne doivent pas être pris à la lettre, ce n'est que dans l'expression totale qui résulte de leur ensemble. Il y a même plus, l'Hyperbole, pour être une beauté d'expression et pour plaire, doit porter le caractère de la bonne foi et de la franchise et ne paraître, de la part de celui qui parle, que le langage même de la persuasion. Ce n'est pas tout, il faut que celui qui écoute puisse partager jusqu'à un certain point d'illusion, et ait besoin peut-être d'un peu de réflexion pour n'être pas dupe, c'està-dire, pour réduire les mots à leur juste valeur ». Ver em: FONTANIER, Pierre. Les figures du discours. Paris : Flammarion, 1968, pp. 123-124.

152 MARCHESE, Angelo, FORRADELLAS, Joaquín. Hipérbole. In: Diccionario de retórica, crítica y terminología literaria. Barcelo: Editorial Ariel, 1994, pg. 198.
} 
lúcido, está ancorado dentro do seu mundo, sem ter o descortino completo da situação que vive. Daí, noutros contos, a sua visível submissão a um geral a que não tem acesso, embora demonstre muita indignação quanto aos fatos à primeira vista sem sentido que está obrigado a suportar. E isto é o que acentua tanto sua condição de sonhador tateante num mundo de ordem aparentemente irreconhecível, onde ele só esbarra em enganos, como se caminhasse, consciente e pensativo, num estado hipnótico, a mando de um demiurgo inexistente. ${ }^{153}$

Com efeito, a ironia prefigura-se constantemente nos contos de Murilo Rubião e, de maneira geral, nasce da quebra de expectativas entre a reação pouco assombrada e, até mesmo, desapontada dos personagens diante dos exagerados e inexplicáveis acontecimentos sobrenaturais do conto. Ela está nas tentativas absurdas do ex-mágico de se ver livre de seus dons de feitiçaria; no coelhinho que se transforma em canguru e passa a atender pelo nome de Barbosa; no lamento dramático do esposo de Bárbara ao atender os seus pedidos; na linguagem de frases feitas e de trocadilhos, como nota Zagury, do conto Os dragões - que funcionam como “denunciantes da posição coletiva da narração" tipicamente interiorana ${ }^{154}$-; ou, também, na própria escolha dos nomes dos personagens, como aponta Fábio Lucas: "Um capítulo à parte deveria ser destinado às revelações onomásticas. Como, então, chamar de Zeus a um pequeno mentecapto? Como denominar dr. Pink [...] a um analista argentário? "155. O crítico comenta, ademais, a capacidade humorística de Rubião de transformar o destino dramático do protagonista de $O$ lodo, vítima, como já descrevemos, de dores lancinantes devido à metamorfose de seus mamilos em pétalas rubras, numa crítica mordaz acerca da psicanálise ${ }^{156}$.

O comentário de Lucas reforça a habilidade de nosso autor em transformar os desabafos confessionais de seus heróis em narrativas espirituosas em muitos momentos. Mesmo no conto $O$ lodo, em que as dores causadas pelas feridas de Galateu são vivenciadas de maneira mais próxima pelo leitor, Rubião mostra-se capaz de pilheriar a respeito desse sofrimento e das tentativas da irmã e do psicanalista de o ajudarem. O humor consolida-se como a maneira mais recorrente do narrador, seja em primeira, seja em terceira pessoa, de vivenciar a realidade insólita presente de maneira sufocante no universo muriliano. Se o espanto se congela devido à repetitividade enfadonha dos acontecimentos sobrenaturais e pela distância de uma narrativa que já está no passado, resta somente o riso irônico diante de uma experiência já consolidada e que continua incompreensível.

\footnotetext{
${ }^{153}$ ARRIGUCCI JR, Davi. Minas, assombros e anedotas (os contos fantásticos de Murilo Rubião), In: Op. cit. pg. 148.

154 ZAGURY, Eliane. Op. cit. pg. 33.

${ }^{155}$ LUCAS, Fábio. A arte do conto de Murilo Rubião. Estado de São Paulo. São Paulo, 21 de agosto de 1983. Disponível em: www.murilorubiao.com.br. Último acesso: 19/06/2018.

156 Idem, ibidem.
} 
O efeito cômico do conto de Murilo Rubião manifesta-se a partir dessa compreensão minguada diante do universo insólito, onde seus heróis vagam por um espaço hostil e deparamse com situações ininteligíveis e hiperbolicamente sobrenaturais. Por sua vez, as metamorfoses acentuariam tal efeito, ao intensificarem e levarem às últimas consequências os eventos extraordinários das narrativas, dando origem a figuras cada vez mais anódinas e distorcidas. A deformidade pode ser considerada a imagem exemplar da insuficiência, pois representa, precisamente, a subtração da harmonia plástica dos corpos e do espaço-tempo. Por consequência, o efeito cômico se estabeleceria em Murilo Rubião mediante a junção entre os comentários néscios de seus personagens e as imagens deformadas.

Já a ironia, para Jolles, "troça do que repreende, mas sem opor-se-lhe, manifestando-se antes simpatia, compreensão e espírito de participação. Por isso é que ela se caracteriza pelo sentido de solidariedade" 157 . Ainda segundo o estudioso, a ironia pressupõe certa familiaridade entre o inferior e o superior e, também, a participação conjunta entre o autor e o objeto que está sendo ironizado, o que impede a destruição completa deste por intermédio do humor - o que já configuraria a sátira - e pode levar aquele à completa identificação com seu alvo. Ela revela-se como a única arma capaz de relaxar momentaneamente a tensão face o objeto condenável, mas sem negá-lo de todo e sem subvertê-lo.

A partir desse movimento tipicamente irônico de ajuste e desajuste - retomando os termos utilizados por Schwartz para identificar o sentimento do herói-uroboro - que os personagens se deslocam pelo universo muriliano. Essa circularidade de afastamento e de aproximação, no entanto, pode ser vista como um movimento definidor da literatura do século XX em sua totalidade e não como uma especificidade da obra de Murilo Rubião. Wladimir Krysinski, por exemplo, vê no texto irônico uma das invariáveis da narrativa ficcional do período, justamente por constituir um "espaço dialético que relativiza a pretensão, todas as pretensões de um sentido único"158. A ironia, portanto, pode dar vazão à subjetividade que marca a literatura do Novecentos, quando "o sujeito sem sua forma anômica, crítica, idiossincrática retorna com força e constitui um apoio sempre essencial da modernidade, uma modernidade que renova sistematicamente seus parâmetros e sua escrita" ${ }^{159}$.

${ }^{157}$ JOLLES, André. O chiste. In: Formas simples. Trad. CABRAL, Alvaro. São Paulo: Editora Cultrix, 1976, pg. 211.

${ }^{158}$ KRYSINSKI, Wladimir. Entre as crônicas da modernidade e os discursos evolutivos da literatura do século XX. In: Dialéticas da transgressão. Trad. NEIS, Ignacio Antonio; PETERSON, Michel e CANKO, Ricardo Iuri. São Paulo: Perspectiva, 2007, pg. XXV.

${ }^{159}$ Idem, ibidem. 
Ainda segundo Krysinski, o texto moderno de ficção, que se renova a cada ato e que não consegue se estabelecer num solo firme de valores universais - seja na esfera moral, seja na esfera estética -, firma-se, precisamente, em sua "capacidade irônica de multiplicar as perspectivas e de relativizar a narrativa e sua leitura" ${ }^{160}$. A relativização da narrativa e as diversas perspectivas por ela assumidas têm, como consequência, a fragmentação do ponto de vista do narrador/autor diante do universo que precisa ser transposto à ficção. Conforme o crítico polonês, há um elo solidário entre a fragmentação da narrativa e o discurso irônico, nascido "de uma vontade e de uma obrigação de estruturar simbolicamente a totalidade" 161 .

Essa tentativa de simbolização, que escapa à experiência falha do escritor - seja o poeta, seja o ficcionista - em compreender seu mundo e que o coloca, de maneira constante, em combate contra a impossibilidade de transmitir por meio da escrita qualquer relance de entendimento das coisas, deu origem a textos que se curvam à violência do universal e que investem na potência do fragmento. Desde os versos espantados de Baudelaire diante das cenas parisienses, passando pelo poema referencial de T. S. Eliot e pelos vários romances - como os de Virginia Woolf, Robert Musil e William Faulkner - que "respondem pelo fragmentário à pressão do total, do histórico, do político, do urbano" ${ }^{162}$, saiu de cena a pretensão ilusória de uma visão completa do artista e passaram a ser apreciados o relance, o vislumbre e a própria incompreensão.

A junção do discurso irônico e do ponto de vista fragmentário acaba por desaguar no caráter auto-reflexivo dessa literatura que se estruturou, apesar das fissuras, no fim do século XIX e que deu o tom da produção do século XX. Rindo irônica e insistentemente de si mesma e informada de antemão a respeito da sua incapacidade de se desvencilhar dos limites de um estilhaço de experiência, a obra literária, por consequência disso, estreita seus objetivos e passa a refletir sobre sua própria validade e sobre sua própria realização ${ }^{163}$. Segundo Krysinski, essa

\footnotetext{
${ }^{160}$ Idem, ibidem. pg. XXVI.

${ }^{161}$ Idem, ibidem.

162 Idem, ibidem. pg. XXVII.

${ }^{163}$ Essa leitura histórica de Wladimir Krysinski está em sintonia com as reflexões de Clement Greenberg sobre as mudanças acontecidas nas artes plásticas no início do século XX. O crítico norte-americano afirma que essa volta dos meios artísticos para si mesmos foram a consequência da autocrítica iniciada por Kant que, com seu método filosófico de criticar a lógica a partir da própria lógica, impeliu que todas as atividades formais se justificassem pelos seus próprios meios, inclusive as artes. Dessa forma, cada atividade artística precisou mostrar seus efeitos exclusivos, aquilo que lhe era único e irredutível. Seguindo tal raciocínio, isso explicaria o porquê de a pintura ter se voltado para o nível bidimensional, abrindo mão de suas técnicas de perspectiva, uma vez que o elemento da pintura que lhe é único e que a diferencia de todas as outras artes é o próprio plano em que ela é produzida, ou seja, a tela. Greenberg contextualiza a pintura modernista como fruto último, justamente, dos processos iniciados na segunda metade do século XIX, e não como uma ruptura da história artística: "Each art, it turned out, had to perform this demonstration on its own account. What had to be exhibited was not only that which was unique and irreducible in art in general, but also that which was unique and irreducible in each particular art. Each art had to determine, through its own operations and works, the effects exclusive to itself. By doing so it would, to be sure,
} 
nova característica da literatura "define a obra como um universo autônomo, esteticamente determinado, como um discurso auto-referencial", e "garante uma percepção do texto moderno como trabalho da forma" ${ }^{164}$. Com o passar do tempo, portanto, a ficção - assim como os outros gêneros artísticos, tanto literários quanto visuais e sonoros - jogou cada vez mais com os seus recursos constitucionais e viu-se não mais como expressão ou meio estético dirigidos, a priori, a ideias e a valores universais, mas como um fim em si mesma. Assim, os gêneros da prosa contos, romances, novelas - não deveriam mais buscar o seu valor no mundo exterior, mas precisavam rastrear sua validade dentro de seus próprios limites formais.

Como vimos anteriormente, a prosa de Rubião não foge a essa inclinação generalizada, no século XX, do texto que se debruça sobre o próprio texto (conforme vimos no capítulo 1) e que dá origem ao riso irônico em todas as instâncias da narrativa - o autor, o narradorpersonagem e o leitor. No entanto, a maneira de rir de si mesma não se manifestou de modo único em toda a produção literária do período. Jacques Rancière observa, por exemplo, que o riso irônico na narrativa teve início muito antes do século XIX, já no Dom Quixote. Para o filósofo, Cervantes inaugura a tendência entre os escritores de ver o trabalho literário como um jogo que, com o tempo, bifurcou-se em duas teologias da narrativa que ele denomina "fábulas do escrito órfão" - histórias que se distanciaram do "relato partilhado" dos tempos míticos primitivos. Na primeira, em que ele inclui Machado de Assis:

[...] a fábula do escrito órfão serve para exaltar a figura do escritor/Deus, onipresente em sua criação, livre para nela intervir e dela se retirar, para dar e tirar corpo a seus personagens e a sua história, organizando assim sua ficção no abismo de um enigma ou no reflexo infinito de um jogo de espelhos. Daí se inspiram o jogo do autor, do narrador e do personagem onde se ilustrarão Fielding e Sterne antes dos românticos alemães, e que será retomado por Machado de Assis; as ficções borgianas dos palimpsestos, dos labirintos e das bibliotecas; a teorização schlegeliana de uma literatura capaz de uma reflexão ao infinito, do romance que se faz teoria poética do romance... Ao fazer seu personagem quebrar os círculos do relato partilhado, o romance paradigmático de Cervantes abre então caminho para essa consciência triunfante da literatura como jogo de uma reflexão infinita e de um segredo cuja fórmula o mestre não para de ocultar. ${ }^{165}$

A essa tendência do escritor que tem pleno domínio dos segredos de seu universo fictício e que controla as diversas variáveis do jogo narrativo com tranquilidade e mãos de ferro, além de dispor de seus personagens como se fossem reféns de sua mestria, Rancière opõe uma outra teologia do romance. Nesta, os limites que apartavam mestre e refém se ofuscam e não deixam

narrow its area of competence, but at the same time it would make its possession of that area all the more certain". Ver em: GREEMBERG, Clement. Modernist painting. Forum Lectures, 1960. Disponível em: http://www.sharecom.ca/greenberg/modernism.html. Último acesso: 19/06/2018

${ }^{164}$ KRYSINSKI, Wladimir. Op. cit. pg. XXVII.

${ }^{165}$ RANCIÈRE, Jacques. Teologias do romance. In: Políticas da escrita. Trad. RAMALHETE, Raquel; RIBEIRO, Eloisa Araújo; VASSALO, Ligia e VILANOVA, Laís Eleonora. São Paulo: Editora 34, 2017, pg. 80. 
mais transparecer qualquer relação entre dominador e dominado. Pelo contrário, tal situação pode até mesmo se inverter e abrir a possibilidade de o escritor/mestre vir a ser controlado por uma literatura que se soberaniza: "a literatura absolutizada é a literatura na qual a relação [mestre-refém] se inverte num movimento em cujo termo o próprio escritor vem para o lugar do refém" 166 . Conclui-se, dessa forma, o último grau da narrativa voltada a si mesma e que tiraniza os desígnios e os desejos do escritor. Se antes era ele que estava na posição de rir ironicamente dos seus personagens/reféns, o autor, na segunda teologia do romance, desce de seu pedestal, une-se às suas criaturas e torna-se igualmente objeto de seu riso cada vez mais amargo.

Embora as duas tendências expostas pelo filósofo francês evidenciem a perpétua ou, ao menos, muito antiga preocupação do romance em refletir sobre os seus próprios pressupostos e valores artísticos - o que contraria a afirmação feita por Krysinski de que isso seria um fenômeno exclusivo da modernidade -, há decerto em suas reflexões uma suspeita de que a segunda teologia passou a ser dominante no mesmo período apontado pelo crítico polonês, a partir do esgarçamento da frase por Proust e do esgotamento do verso por Mallarmé. A literatura, portanto, que continua um jogo dela com ela mesma, abandona as cartas marcadas e transforma-se em combate interno travado numa arena de crises.

A crescente inferioridade do escritor diante de seu objeto resulta, como observamos anteriormente na definição de Jolles, num sentimento de identificação que origina o efeito irônico. Além disso, a mudança de posições analisada por Rancière ao longo da história do romance (e grosso modo em todos os gêneros da prosa, inclusive o conto), coaduna-se à distinção pensada por Arrigucci entre Murilo Rubião e seu mestre Machado. Com efeito, vimos na última citação do crítico $^{167}$ que o escritor mineiro, ao contrário de seu influenciador fluminense, encolhe - e quase anula - a distância entre o ponto de vista do narrador, incapaz de relativizar suas experiências, e o mundo que o circunda e que lhe é indecifrável. O herói muriliano, que possui aquele "caráter intermediário" sobre o qual comenta Lukács, não tem acima dele um mediador que o interprete e que veja "o mundo na sua contraditoriedade móvel" ${ }^{168}$. Entre o leitor e o narrador/protagonista, conforme visto ao longo deste capítulo, não há senão um relato frustrado a respeito, justamente, da incapacidade de compreensão por parte

\footnotetext{
166 Idem, ibidem. pg. 81.

${ }^{167}$ Ver nota de rodapé 153

${ }^{168}$ LUKÁCS, Georg. Narrar ou descrever? In: Ensaios sobre literatura. Trad. KONDER, Giseh Vianna. Rio de Janeiro: Civilização Brasileira, 1965, pg. 78.
} 
do herói. Sujeito e objeto, portanto, colam-se e dão origem à ironia do constante estado de insciência que envolve as instâncias da narrativa.

Já na obra de Machado de Assis, a distância entre os dois polos narrativos mantém-se mesmo em seus romances mais experimentais e metalinguísticos. Em Esaú e Jacó, por exemplo, romance que reflete sobre a própria forma romanesca e no qual o enredo mingua ao lado dos comentários sobre a arte de contar uma história, o narrador em terceira pessoa mostrase bastante confortável em seu laboratório literário. A saga dos irmãos gêmeos, de sua relação ativa com as mudanças do país à época da narrativa - que se passa na transição do Império para a República - e de seu amor pela mesma moça, desenrola-se tal qual um jogo em que o narrador autossuficiente brinca com seus personagens como se estes fossem peças dispostas sobre um tabuleiro. Seu riso permeia todo o romance e origina-se da sua própria onipotência, que lhe permite dispor de suas criaturas (ou reféns, como prefere Rancière) a partir da distância absoluta do criador (ou do mestre).

A ironia da narrativa surge, à vista disso, de sua habilidade em adiantar, sugerir e descartar as peripécias do enredo, pois sabe que isso lhe é permitido devido à sua posição. $\mathrm{O}$ narrador consegue, até mesmo, adivinhar a reação de seus leitores caso escolha uma ou outra reviravolta. Hélio Guimarães, por exemplo, lança mão da metáfora do xadrez para comentar esse romance de Machado que, segundo ele, já pode ser entrevista em publicações anteriores do autor, como Dom Casmurro:

Assim, o xadrez comparece em Esaú e Jacó como metáfora sintética e complexa do jogo ficcional, em que virtualmente qualquer situação pode ser construída com os mesmos personagens sobre um mesmo chassi. Trata-se da depuração de uma ideia já presente em Dom Casmurro, em que o narrador também chama a atenção para o fato de que todas as histórias podem ser reduzidas a uma mesma matriz [...]. ${ }^{169}$

De fato, a construção do que o crítico chama de "romance em abismo", ou seja, da narrativa que se debruça sobre ela mesma e mostra os bastidores da criação literária (a autoreflexividade de Krysinski), estimula o olhar irônico do escritor ante seu trabalho. Uma vez que todas as histórias possuem um denominador comum, o trabalho do escritor resume-se a manipular esses elementos que ele conhece tão bem. Assim, o recurso de mise en abyme, como no caso já mencionado de Borges ou nos romances de Gide, indica com benevolência o caráter artificial da ficção e serve costumeiramente como prova de virtuosismo do escritor e do seu narrador/mediador.

A ironia leve e descompromissada nascida, nesse caso, da mise en abyme - que não necessariamente implica efeitos humorísticos, como vimos no impasse da literatura moderna

${ }^{169}$ GUIMARÃES, Hélio. Introdução: Um romance em abismo. In: ASSIS, Machado de. Esaú e Jacó. São Paulo: Penguin Classics Companhia das Letras, 2012, pg. 19. 
de refletir sobre sua própria validade - beira o riso satírico de Gógol ao manipular os títeres petersburguenses. Há entretanto uma mudança estrutural na ironia operada pelo humor angustiado da obra de Murilo Rubião ${ }^{170}$. E isso pode ser observado, nos contos do escritor, pela transformação de recursos cômicos tradicionais - manipulados com maestria pelos humoristas da literatura e também presentes na prosa de Rubião - em situações desenfreadas que vão de encontro ao seu mestre. Quando o riso se volta contra o seu próprio criador - e a respeito desse movimento fazemos coro às considerações de Rancière e de Krysinski -, desaparece a comodidade do leitor e do narrador por causa de um possível reconhecimento com o sujeito que ri ante o objeto risível e, de súbito, as posições se invertem.

Para desencadear essa virada de chave entre sujeito e objeto do riso irônico, as metamorfoses desempenham um papel fundamental na prosa de Rubião. Em suas considerações a propósito dos instigadores e dos estimuladores do riso, Henri Bergson afirma que uma das razões mais primordiais e mais recorrentes do efeito cômico pode estar no artificialismo do corpo, pois "as atitudes, os gestos e os movimentos do corpo humano são risíveis na exata medida em que esse corpo nos faz pensar numa simples mecânica"171, e acrescenta que "o efeito cômico será mais marcante, a arte do desenhista será mais consumada quanto mais inseridas estas duas imagens estiverem uma na outra: a imagem de pessoa e a de mecanismo" ${ }^{172}$. Bergson reconhece, portanto, o poder cômico de transfigurar o homem em fantoche articulado, ou num autômato enrijecido.

A mecanização que substitui a espontaneidade do corpo, de tudo aquilo "estranho à nossa personalidade viva" ${ }^{173}$, gera consequências que, segundo o filósofo francês, podem ser vistas como uma das variáveis mais profícuas dos recursos cômicos: "Adivinhamos que os

\footnotetext{
${ }^{170}$ Parece-nos que a definição do que é ironia e de como ela pode ser encontrada e definida na literatura está muito mais ligada aos humores de uma época do que a qualquer definição retórica. Com efeito, o que nos parece satírico em Machado de Assis pode também ser visto, em outros momentos, como irônico pela crítica. O caminho inverso pode ser traçado, também, e os estudiosos de um tempo podem encontrar ironia em textos antigos que lidavam seriamente com seus assuntos. Ian Watt, por exemplo, mostra como a crítica do século XX viu a obra de Daniel Defoe, sobretudo Moll Flanders, como um conjunto de textos carregado de senso irônico. O crítico inglês, no entanto, desconfia das intenções humorísticas de Defoe e afirma que há muito pouca ironia nas aventuras de sua heroína mais famosa: "[...] como podemos explicar que um romance que não foi concebido para ser irônico acabou sendo visto como tal por muitos leitores modernos? Parece que devemos buscar a resposta não na crítica literária, mas na história social. Não podemos acreditar hoje que um homem inteligente como Defoe encarasse as atitudes econômicas ou as declarações piedosas de sua heroína com alguma outra atitude que não a do escárnio. Entretanto suas outras obras não corroboram essa opinião, e pode ser que o curso da História nos tenha predisposto, muitas vezes até inconscientemente, a ver com ironia certas questões que Defoe e seu tempo encaravam com grande seriedade". Ver em: WATT, Ian. Defoe romancista: Moll Flanders. In: A ascensão do romance. Trad. FEIST, Hildegard. São Paulo: Companhia das Letras, 2010, pg. 137

${ }^{171}$ BERGSON, Henri. O riso: ensaio sobre a significação da comicidade. Trad. BENEDETTI, Ivone Castilho. São Paulo: Martins Fontes, 2004, pg. 22

${ }^{172}$ Idem, ibidem. pg. 23.

${ }^{173}$ Idem, ibidem. pg. 24
} 
artifícios usuais da comédia, a repetição periódica de uma palavra ou de uma cena, a inversão simétrica dos papeis, o desenvolvimento geométrico dos quiproquós e muitos outros jogos poderão extrair força cômica da mesma fonte" ${ }^{174}$. Será, portanto, a partir da mecanização dos gestos que as principais maneiras de se fazer humor surgirão, pois, a partir dessa focalização no corpo, o olhar do espectador não alcança os conflitos morais dos personagens e detém-se em sua superfície grotesca.

Seguindo os argumentos de Bergson a respeito da automatização e da mecanização do corpo como recurso de humor, percebemos que as metamorfoses nos contos de Murilo Rubião funcionam pelo mesmo viés. Ao longo deste capítulo, os mecanismos metamórficos encontrados na narrativa muriliana foram, justamente, apresentados em seus aspectos mais artificiais, mais ornamentais e mais maquinais ${ }^{175}$. Se, por um lado, o descontrole dessas transfigurações expõe o acento trágico dos contos e contribui para a ruína do herói, por outro lado, ele também é o responsável pelo tom humorístico que perpassa as narrativas. Vimos, por exemplo, que o percurso tragicômico do ex-mágico, do pirotécnico Zacarias e de Aglaia vem como resultado direto das mutações automáticas e descontroladas a que eles estão submetidos. Contudo, como o foco do narrador atém-se às mudanças físicas e materiais sofridas ou originadas por seus personagens e não em seus conflitos interiores, aquilo que deveria suscitar nosso pesar acaba por nos fazer rir. Ainda que o comportamento generalizado de teatro de marionetes contribua para a atmosfera espetacular dos contos de Rubião, a ausência de cordéis firmes para manipulá-los acaba por distanciá-los dos bonecos sombrios de Hoffmann e da

\footnotetext{
${ }^{174}$ Idem, ibidem. pp. 26-27.

${ }^{175}$ Há, com efeito, uma forte relação entre maquinário e o teatro. Tradicionalmente, máquina designava todo objeto ou artifício que representava, sobre o palco, verdades maiores que a própria encenação. Daí a estreita conexão entre ambos e a submissão das engenhocas mecânicas às necessidades dramáticas. Com o tempo, a relação entre homem e máquina perverte-se e altera o próprio sentido desta palavra, que perde sua ligação com o divino e se volta contra os homens. Gerd Bornheim apresenta uma breve síntese da evolução das máquinas no teatro e de seu significado linguístico: "Veja-se o que acontece com a máquina dentro da cultura clássica grega: ela era antes de tudo máquina do teatro, estava literalmente a serviço da divindade, fazia aparecer e desaparecer, era um artifício que se punha à disposição daquilo que na época se considerava como sendo a própria presença física da deusa, da Justiça, da medida do homem. E, ainda que em termos totalmente outros, o mesmo vale para as montagens do teatro medieval: cabia à máquina repetir o insólito dos milagres, revelar a essência dos mistérios, tornar manifesto o esplendor das esferas divinas e as agruras do fogo do inferno; mais uma vez, a máquina, em sua expressão desenvolvida - e surpreendentemente desenvolvida -, estava comprometida com a verdade absoluta. E tal situação se prolonga ainda no início dos tempos modernos, até o momento preciso do final do barroco: é sempre uma complexíssima máquina que deve pôr o homem em contato com os elementos divinos. Claro que, com a Revolução Industrial, as máquinas passam por uma transformação que afeta essencialmente seu sentido, sua função, sua própria razão de ser, a ponto de a maioria das histórias da máquina até ignorarem completamente a dimensão essencialmente religiosa da antiga e prodigiosa máquina teatral. Agora, os liames com a revelação do divino se desfazem, e a evolução da máquina passa a efetuar-se exclusivamente dentro dos limites em que acontecem as relações entre sujeito e objeto. A dicotomia sujeito-objeto parece então esgotar as fronteiras de todo o desenvolvimento da máquina hodierna". Ver em: BORNHEIM, Gerd. Ecologia e revolução tecnológica. In: Temas de filosofia. São Paulo: Editora da Universidade de São Paulo, 2015, pg. 235.
} 
tradição romântica, embora a distorção de suas formas ainda causem efeitos aterradores sobretudo quando acompanhada de uma escrita hiperbólica que eleva ao máximo a desfiguração dos personagens e de seu universo. Além disso, as criaturas que se movem nas narrativas de Rubião, embora humanas, não possuem o mesmo ímpeto dos autômatos e bonecos do Romantismo, ávidos para se libertarem das cordas dos homens. Pelo contrário, seus personagens parecem vagar à cata de um liame qualquer.

Também vimos, contudo, que à feição trágica da máscara grotesca sempre corresponde uma face cômica. Afinal, o teatro de marionetes tem como traço apriorístico o divertimento de seu público. Se a distância entre autor e os objetos da narrativa se sustentasse por meio do vigor dos cabos que separam o manipulador dos seus autômatos - como acontece na obra de Gógol e no romance Esaú e Jacó, de Machado de Assis -, o efeito hilariante estaria garantido. As metamorfoses nasceriam e se desenvolveriam ao bel-prazer do manipulador das cordas, ansioso por mostrar suas habilidades. No entanto, os velhos truques de repetição e de automatização voltaram-se contra ele, e o conforto da gargalhada fácil do espectador distante da caixa dos títeres transforma-se em riso sardônico.

Apesar da inversão de ordens do palco muriliano e da aparente inutilidade de qualquer tentativa de exercer certo controle sobre a finalidade de seu papel, grande parte de seus personagens rebela-se contra a irrelevância de suas escolhas. Como consequência, muitos deles buscam nas metamorfoses um antídoto à frivolidade. Recorrem sobretudo aos animais, esse outro ao mesmo tempo tão distante e tão próximo do homem. Como veremos a seguir, as formas animais escolhidas pelos personagens murilianos são várias e, frequentemente, fogem às representações mais tradicionais. Afinal, acabada a tirania das cordas, resta ao menos a liberdade dos movimentos. 


\title{
CAPÍTULO III: "Fronteiras e atalhos entre o homem e o animal: a metamorfose em
} Teleco, o coelhinho e Alfredo"

\begin{abstract}
E o senhor acha possível viver diante de um espelho que, além disso, não contente de nos congelar com a imagem da nossa própria expressão, ainda nos devolve esta imagem, como uma careta irreconhecível de nós mesmos?
\end{abstract}

(Luigi Pirandello)

A aparente ausência de regras dentro da ficção de Murilo Rubião parece inclinar-nos à conclusão de que não há traços de causalidade ou de intencionalidade dentro de seus limites. Qualquer fim expresso do autor na escolha, por exemplo, das imagens criadas e apagadas por suas metamorfoses figura-se improvável. No mundo grotesco de seus contos, onde qualquer transgressão da normatividade empírica é possível, a única regra que suspeitamos valer é a da deformação, sem que importem, para isso, as figuras resultantes. Dessa forma, num primeiro momento, a estética deformadora salta aos olhos e abafa, devido a sua força de movimentação e de destruição, as imagens que estão sendo desfiguradas e transfiguradas. Pouco nos importa se da cartola do ex-mágico da Taberna Minhota sairá um pombo ou um jacaré quando o mecanismo que origina esses encantamentos - presumidamente ilusórios - sai do plano da fantasia e, sem controle, passa a alterar a realidade. De início, as metamorfoses parecem resumir-se às suas próprias engrenagens e não às imagens que elas são capazes de conjurar, bloqueando interpretações ligadas às formas que estão em jogo. Elas funcionariam, portanto, como um espetáculo técnico e ornamental de uma realidade sem regras.

A partir de uma leitura mais atenta, porém, percebemos que algumas imagens originadas pelas metamorfoses são suficientemente relevantes para a narrativa. Como visto anteriormente, as filhas com olhos de vidro de Aglaia, por exemplo, retomam uma tradição do autômato como duplo do homem - iniciada séculos antes por Hoffmann e continuada pela literatura fantástica dos Oitocentos e pelo romantismo europeu. A permeabilidade entre o corpo humano e o corpo artificial não se caracteriza, por sua vez, como a única estratégia do autor para colocar sob sua lente o limite - ou a ausência de limite - entre as diferentes formas encontradas no mundo.

Dentro dessa ficção sobriamente desordenada, algumas imagens destacam-se por sua assiduidade ou por sua significância nos contos de Rubião, como no caso dos animais. Ora pelo caminho do antropomorfismo, ora pela via do zoomorfismo, o animal consolida-se como figura recorrente nas metamorfoses. Embora, em algumas narrativas, eles apareçam somente como 
mais um resultado insólito do emaranhado de transformações a que os personagens murilianos estão submetidos, em outras - como Teleco, o coelhinho e Alfredo -, os animais são peçaschave para o desenvolvimento, o clímax, o desfecho e a interpretação do conto.

Logo, neste capítulo, analisaremos a presença animal em ambas as narrativas sem ignorarmos a relevância do conto Os dragões que - embora não tenha metamorfoses - também lida diretamente com a presença animal. Compararemos a trajetória de Teleco e de Alfredo, buscando suas semelhanças e suas diferenças, além de discutirmos as formas animais escolhidas pelos dois personagens. Em Teleco, o coelhinho, traçaremos o caminho realizado pelo animalzinho, que parte dos animais simbólicos - como o coelhinho - para as criaturas estrangeiras e pouco familiares ao leitor - como o canguru. Já em Alfredo, dialogaremos com o paralelo existente entre o homem-dromedário que dá nome ao conto e a figura do lobisomem, citada no início da história. Além disso, refletiremos sobre sua preferência - tal qual Teleco por animais excêntricos e não tradicionais à literatura. Por fim, discutiremos a falta de limites nítidos entre o homem e o animal em Murilo Rubião e a técnica narrativa do estranhamento resultado da presença animal na literatura e de sua relação injusta e complexa com o homem.

\section{As metamorfoses de Teleco: os animais na ficção de Murilo Rubião}

As lembranças nostálgicas de um homem, que olhava o mar à procura de tempos e amores passados, são bruscamente interrompidas por uma voz que lhe pede um cigarro. Irritado com o pedinte, que ele julgava ser um pivete de rua, o homem ordena-lhe de maneira ríspida que o deixe em paz. Sua raiva não se aplaca senão no momento em que, no lugar do suposto menino, ele depara-se com um pequeno coelhinho chamado Teleco. A amizade entre os dois inicia-se rápida e facilmente, o dócil animalzinho torna-se companhia inseparável do herói do conto e logo eles passam a morar juntos. Além disso, a fim de tornar-se ainda mais encantador para seu novo parceiro e para sua nova vizinhança, motivado pelo "simples desejo de agradar ao próximo" ${ }^{176}$, Teleco tinha a curiosa mania de transformar-se em outros animais.

A relação dos dois amigos começa a mudar quando, retornando de uma discussão com parentes acerca dos negócios da família, o narrador-protagonista encontra Teleco metamorfoseado em canguru ao lado de uma moça no sofá da sala de visitas. A despeito da sua forma animalesca, Teleco está convencido de que agora é um homem e passa a atender pelo nome de Barbosa. O canguru tem hábitos terríveis e grosseiros que chocam o dono da casa,

\footnotetext{
${ }^{176}$ RUBIÃO, Murilo. Teleco, o coelhinho. In: Op. cit. pg. 53.
} 
além de suas feições também lhe serem repugnantes: "A pele era gordurosa, os membros curtos, a alma dissimulada. Não media esforços para me agradar, contando-me anedotas sem graça, exagerando nos elogios à minha pessoa" ${ }^{\prime 17}$. Para complicar ainda mais o relacionamento dos dois amigos, o herói apaixona-se por Tereza, a namorada de Barbosa, que recusa sua proposta de casamento.

Passado algum tempo de separação, os dois amigos voltam a se encontrar num dia em que Teleco reaparece na casa do protagonista sob a forma de um cachorro. $\mathrm{O}$ animal passara aquele tempo usando seus dons extraordinários em apresentações mágicas na cidade. Abandonado por Tereza - de cuja ausência não sabemos a razão -, solitário e incapaz de estabelecer um diálogo com o narrador, o bichinho adoece e perde o controle de sua habilidade metamórfica, assumindo, incessantemente, a forma de outros animais. Teleco definha até a morte, quando, por fim, assume uma forma terrivelmente humana:

\begin{abstract}
Alguns dias transcorridos, perdurava o mesmo caos. Pelos cantos, a tremer, Teleco se lamuriava, transformando-se seguidamente em animais os mais variados. Gaguejava muito e não podia alimentar-se, pois a boca, crescendo e diminuindo, conforme o bicho que encarnava na hora, nem sempre combinava com o tamanho do alimento. Dos seus olhos, então, escorriam lágrimas que, pequenas nos olhos miúdos de um rato, ficavam enormes na face de um hipopótamo. Ante a minha impotência em diminuir-lhe o sofrimento, abraçava-me a ele, chorando. O seu corpo, porém, crescia nos meus braços, atirando-me de encontro à parede. Não mais falava: mugia, crocitava, zurrava, guinchava, bramia, trissava. Por fim, já menos intranquilo, limitava às suas transformações a pequenos animais, até que se fixou na forma de um carneirinho, a balir tristemente. Colhi-o nas mãos e senti que seu corpo ardia em febre, transpirava. Na última noite, apenas estremecia de leve e, aos poucos, se aquietou. Cansado pela longa vigília, cerrei os olhos e adormeci. Ao acordar, percebi que uma coisa se transformara nos meus braços. No meu colo estava uma criança encardida, sem dentes. Morta. ${ }^{178}$
\end{abstract}

A partir desse breve resumo, notamos que a derradeira imagem de Teleco contrasta violentamente com o dócil e cativante coelhinho que interrompe os devaneios do narrador diante do mar, completando um arco que parte das figuras racionalmente acabadas aos corpos mais deformados e desarmonizados. As metamorfoses, à vista disso, dividem-se em três momentos. De início, elas dão origem a seres perfeitos e reconhecíveis tanto para o protagonista quanto para o leitor, guiadas pela ânsia do coelhinho em ser agradável. O segundo momento principia-se com seu desejo por novas e estranhas formas animais e passa pela transformação dessa vez fixa e longeva - de Teleco no canguru humanoide Barbosa, culminando no fim de sua amizade com o narrador. Após o reaparecimento da criatura metamórfica, as mutações saem de controle e o que parecia ordenável e classificável corrompe-se em transformações rápidas

\footnotetext{
${ }^{177}$ Idem, ibidem. pg. 56.

${ }^{178}$ Idem, ibidem. pg. 59.
} 
que dão origem a seres bestiais, cujos corpos desproporcionais são dificilmente reconhecíveis, caracterizando o terceiro momento das transfigurações.

Afora a ausência de espanto do narrador face ao sobrenatural - traço comum a quase todas as narrativas de Rubião - mais uma vez, ao longo do conto, cria-se o jogo entre falta e excesso que também está presente em outras narrativas do autor. A oposição entre o encantamento mediante a habilidade de transformar-se em outros animais e o corpo horripilante e asqueroso de Teleco ao morrer promove, dessa maneira, um quadro esteticamente grotesco. Afinal, sensações maravilhosas e terríveis podem surgir da mesma criatura e de seu poder de transfiguração. O mesmo corpo capaz de criar figuras fantásticas é também aquele que encontra seu fim sob uma forma onde falta qualquer traço de ajustamento. A deformação de Teleco dáse de maneira tão intensa que o próprio protagonista, ao narrar seus últimos momentos com a criatura, afirma, antes de tudo, que aquilo que ele sentia em seu colo, apesar de humano, era também uma coisa.

Segundo Alexandre Eulálio - que analisou a presença animal na narrativa de nosso autor -, no conto Teleco, o coelhinho, o leitor está diante de "um naturalista transviado, que abdicou por tédio dos seus sistemas classificatórios. Um naturalista demissionário que preferiu manipular as pranchas científicas, que antes ele apenas registrava, num calidoscópio fantasmagórico, que varia desde os ritmos mais lentos até os mais frenéticos" ${ }^{\text {"179 }}$. Se as primeiras formas de Teleco, por circunscreverem-se no âmbito dos animais domésticos ou dos animais selvagens mais triviais, logo cativam o narrador e o leitor pela sua docilidade e sua afabilidade, suas últimas formas desproporcionais e seu corpo morto semi-humano, tal e qual as meninas de olhos de vidro do conto Aglaia, asseveram um efeito horripilante, tipicamente grotesco, daquilo que se encontra no limiar da familiaridade e da estranheza. Ainda segundo o crítico, as transformações de Teleco podem ser consideradas um galopante teatro de marionetes, cujo desfecho se dará sob a máscara da morte: “esse metamorfosear e transformar encerra-se, finalmente, numa derradeira máscara de cera pavorosa, com a morte. É aí que tem vez o macabro" 180 .

Para Eulálio, o conto de Murilo Rubião funciona como uma mesa de dissecação sobre a qual todas as figuras da narrativa são destroçadas até o próprio raciocínio do leitor sofrer o mesmo processo, pois ela “acaba por desmembrar o raciocínio lógico com o mesmo minucioso

\footnotetext{
${ }^{179}$ EULÁLIO, Alexandre. Animais de estimação. In: O Globo. Matéria e Memória, Rio de Janeiro, 23 de agosto de 1965, pg. 3. Disponível em: http://www.murilorubiao.com.br. Último acesso: 19/06/2018.

${ }^{180}$ Idem, ibidem.
} 
furor frio do menino que destroça um inseto" ${ }^{181}$. De um mundo aparentemente organizado, embora sobrenatural, surge, pouco a pouco, a desestabilização total do corpo de Teleco, cujos disfarces animais - ou máscaras - já não se fixam mais de acordo com a sua vontade própria.

Assemelhando-se às figuras animalescas da commedia dell'arte - analisadas por Wolfgang Kayser ${ }^{182}$-, onde o corpo dos atores reveste-se, justamente, de máscaras e de fantasias que fazem alusão a figuras animais, a fim de criar uma figura híbrida para seu espetáculo, as figuras metamórficas de Teleco parecem oscilar nessa mesma dinâmica. Jorge Schwartz aponta que, como os encantamentos do ex-mágico, as metamorfoses do coelhinho também podem ser lidas como uma tentativa de fugir do tédio de sua própria condição, em que as transformações seriam a espetacularização dessa investida: "Teleco afirma que os animais conhecidos são insípidos, então a transformação, assim como as mágicas do ex-mágico, converte-se no meio de luta contra o Tedium Vitae" ${ }^{\text {"183. }}$

Quer Eulálio, quer Schwartz constatam em suas análises acerca do papel do animal dentro da obra de Murilo Rubião, especialmente no conto Teleco, o coelhinho, a aproximação que essa figura estabelece com o disfarce. Para ambos os críticos, as inúmeras metamorfoses de Teleco são reflexos superficiais dos humores e dos desejos profundos do animalzinho. Elas seriam o resultado de uma busca pela fixação de um papel no mundo, fantasias que tentam expressar aquilo que o coelho dissimula sob a obrigação de ser agradável aos outros. Ao entediar-se com seu papel subserviente e cansado de ser visto como um títere, apto a realizar atrações extraordinárias, Teleco imobiliza-se na figura de Barbosa e, nas palavras de Schwartz, "a partir daí, ele passa a usar todos os meios para criar o simulacro do homem, através de artifícios que, na tentativa de encobrir a figura de canguru (cuja posição se assemelha à humana), criam um efeito grotesco. Nasce assim a ironia"184.

O canguru deformado da narrativa, cujos hábitos grosseiramente humanos assustam seu amigo, passa a agir como duplo do homem e espelho daquilo que transparece ser o mais odiável em seu comportamento. Barbosa é uma criatura vil, mesquinha e aduladora - ou, ao menos, é isso que o narrador em primeira pessoa, roído pelo ressentimento com a nova mudança de Teleco e pelo ciúme de Tereza, enxerga nele. A figura pervertida do canguru funciona, consequentemente, devido à sua postura ereta de animal bípede, como paródia de certos procedimentos e de certos modos do homem encarnados por Teleco/Barbosa. Tal procedimento

\footnotetext{
${ }^{181}$ Idem, ibidem.

${ }^{182}$ KAYSER, Wolfgang. Op. cit.

${ }^{183}$ SCHWARTZ, Jorge. Op. cit. pg. 51.

${ }^{184}$ Idem, ibidem. Grifo do autor.
} 
cultural de deturpação da figura dos animais para expor, a partir disso, a própria figura humana dá-se de maneira extremamente recorrente, afirma Dominique Lestel. Ao debruçar-se sobre as complicadas relações em comunidade estabelecidas pelo homem com os animais, o filósofo destaca o uso destes como uma espécie de "terceiro pensante" a respeito daquele:

\begin{abstract}
A animalidade é determinada pelas relações que o homem e o animal desenvolvem em conjunto, e essas relações são submetidas à história do homem. A animalidade evoca limites (de caráter taxonômico) que se revelam, imediatamente, fronteiras (de caráter defensivo). As fronteiras do homem e do animal, do vegetas e do animal, assim como as do artefato e do animal, permanecem intrinsecamente problemáticas em todas as culturas e em particular na cultura ocidental. Numerosas culturas deturpam a figura do animal para falar do homem, como se o que caracterizasse o animal constituísse "um terceiro pensante" ao qual o homem recorre para pensar-se a si mesmo. Fundamentalmente, não é o animal que é digno de interesse, mas aquilo a que ele remete. ${ }^{185}$
\end{abstract}

A figura animal, portanto, antes de ser uma finalidade, funcionou, tradicionalmente, na literatura como despachante entre a intenção do autor e o remate da obra. Do animal, interessavam-lhe apenas os traços que remetiam - obviamente, sob a ótica do homem - às características humanas dignas de serem abordadas dentro dos textos, aspecto fundamental, por exemplo, das fábulas. Isso explica, talvez, a indagação que dá início ao texto de Alexandre Eulálio a respeito da "zoologia doméstica e conformada" dos animais de Murilo Rubião, que “acabam por adotar os mesmos costumes morigerados daqueles senhores, evitando exorbitar certa área civil das convenções, mesmo quando irrequietos por natureza", observação complementada pela pergunta: "Trata-se então de um fabulista?"

A esse questionamento, Eulálio não arrisca dar uma resposta afirmativa ou negativa, limitando-se à descrição da natureza domada das criaturas metamórficas de Rubião, vítimas e não sujeitos - da sua própria monstruosidade. Para exemplificar sua asserção a respeito das feras domesticadas do bestiário de nosso autor, ele cita o conto Os dragões, espécie de fábula muriliana em que uma pequena cidade interiorana é visitada por tais criaturas. Narrado em primeira pessoa pelo professor do povoado, o conto pormenoriza como, paulatinamente, os moradores do vilarejo aproximam-se dos monstros com a intenção de domesticá-los e de civilizá-los, ensinando-lhes bons modos e as regras de sociabilidade. O próprio narrador encarrega-se de tutorear um dos animais - Odorico - que morre de maneira violenta e inexplicável. Embora não haja uma metamorfose física, os dragões remanescentes passam a comportar-se como homens, chegando ao ponto de relacionarem-se com as mulheres da cidade

${ }^{185}$ LESTEL, Dominique. A animalidade, o humano e as "comunidades híbridas". Trad. FUX, Jacques e MACIEL, Maria Esther. In: MACIEL, Maria Esther (org.). Pensar/escrever o animal: ensaios de zoopoética e biopolítica. Florianópolis: Editora da UFSC, 2011, pp 24-25.

${ }^{186}$ EULÁLIO, Alexandre. Op. cit. 
e de viciarem-se em álcool. Seu caráter indômito, próximo ao comportamento humano, garantelhes a incompreensão da cidade e, posteriormente, sua marginalização:

\begin{abstract}
Quando, subtraídos ao abandono em que se encontravam, me foram entregues para serem educados, compreendi a extensão da minha responsabilidade. Na maioria, tinham contraído moléstias desconhecidas e, em consequência, diversos vieram a falecer. Dois sobreviveram, infelizmente os mais corrompidos. Mais bem-dotados em astúcia que os irmãos, fugiam, à noite, do casarão e iam se embriagar no botequim. $\mathrm{O}$ dono do bar se divertia vendo-os bêbados, nada cobrava pela bebida que lhes oferecia. A cena, com o decorrer dos meses, perdeu a graça e o botequineiro passou a negarlhes álcool. Para satisfazerem o vício, viram-se forçados a recorrer a pequenos furtos. No entanto eu acreditava na possibilidade de reeducá-los e superar a descrença de todos quanto ao sucesso da minha missão. Valia-me da amizade com o delegado para retirá-los da cadeia, onde eram recolhidos por motivos sempre repetidos: roubo, embriaguez, desordem. ${ }^{187}$
\end{abstract}

Inseridos nesse contexto conservador, de compadrio e de troca de favores, os dragões não se adaptam ao novo ambiente, à revelia dos esforços do professor em educá-los. Por fim, João, o último remanescente dos dragões, apresenta-se no picadeiro de um circo que passa pelo local a fim de garantir prestígio e renome para si e para a cidade que o acolheu. Depois de exibir alguns truques, frutos de seu adestramento, ele desaparece com a trupe, o que não impede que, a partir daí, mais e mais dragões contornam a cidade todos os anos sem que nela permaneçam, apesar dos apelos do narrador e de seus alunos. Schwartz comenta a inversão simbólica realizada na narrativa, em que o dragão, figura exemplar da teratologia, representa a ingenuidade e a pureza, enquanto os homens comportam-se como verdadeiras bestas: "No conto, a oposição homem/dragão é nítida - só que os valores atribuídos aos mesmos aparecem totalmente invertidos em relação aos conceitos tradicionais. O dragão aparece como elemento 'puro', sem contexto nem história""188.

À semelhança de Teleco, os dragões não são valorizados senão quando oferecem espetáculos agradáveis aos olhos dos homens. Suas funções devem ser sobretudo deleitar e entreter o narrador e os outros personagens, asseverando-lhes atrações inusitadas, como no caso de Teleco, ou momentos cômicos, como os dragões Odorico e João. A partir do momento em que quebram o contrato tácito estabelecido com o grupo que os acolheu - seja a partir de metamorfoses desagradáveis, seja pela vulgarização e pela banalização de seus feitos - eles se veem na posição de párias, tendo que garantir novos meios para manterem-se socialmente. Notemos que, com a finalidade de buscar uma nova posição, tanto Teleco quanto João são obrigados a vender seus dons em apresentações de mágica, único lugar em que tal extravagância pode ser aceita. No entanto, embora consigam firmar-se por um tempo nesses ambientes de trabalho, os dois não granjeiam êxito em seus novos ofícios e deles, também, são eliminados.

${ }^{187}$ RUBIÃO, Murilo. Os dragões. In: Op. cit. pg. 48.
${ }^{188}$ SCHWARTZ, Jorge. Op. cit. pg. 40. 
Jacques Derrida - em suas reflexões acerca da animalidade e de sua presença artística mostra que a literatura, por sua vez, sempre evitou os animais indomesticáveis, intratáveis e inacessíveis ao homem, apontando o processo de afabulação literária na busca por um "amansamento antropomórfico, um assujeitamento moralizador, uma domesticação. Sempre um discurso do homem; sobre o homem; efetivamente sobre a animalidade do homem, mas para o homem, e no homem" "189. Ainda segundo o filósofo, os animais literários são sempre figuras que retomam imagens, metáforas ou símbolos já consolidados por certa mitologia ${ }^{190}$, por personagens oriundos das fábulas. O que Lestel afirma a respeito da deturpação dos animais como uma maneira de mostrar diferentes feições humanas já pode ser visto, portanto, nas considerações de Derrida acerca da utilização maciça, em literatura e nas outras artes, da superfície animal como meio de falar sobre o homem. A animalidade, segundo Lestel, "está ligada àquela dimensão do humano que este oculta, notadamente, ao desqualificar seu corpo, seus desejos ou seus afetos em relação ao seu espírito e à sua racionalidade"191.

Os animais, dessa forma, estariam sujeitos às deformações que os homens reconhecem em si mesmos, servindo tão-somente como maneira de expressão desses desvios. Os animais fabulares são, justamente, aqueles personagens planos que carregam em suas personalidades traços tipicamente reconhecíveis no homem. Dessa forma, eles poderiam servir de exemplo figurativo de conduta para o homem, alertando-o a respeito dos perigos do mundo e despertando sua atenção para as verdades universais que o regem ${ }^{192}$. Os animais, portanto, distinguem-se

${ }^{189}$ DERRIDA, Jacques. O animal que logo sou (a seguir). Trad. LANDA, Fábio. São Paulo: Editora UNESP, 2002, pg. 70.

${ }^{190}$ Derrida dialoga aqui com seu texto A mitologia branca: a metáfora no texto filosófico, onde já está latente sua preocupação a respeito daquilo que é próprio do homem e, consequentemente, os problemas e os desafios de metaforizar aquilo que nos rodeia a partir de nossas próprias características: "As significações transportadas são aquelas das propriedades atribuídas, não aquelas da própria coisa, objeto ou substância. No que a metáfora permanece mediata e abstrata. Para que seja possível, é necessário que, sem envolver a própria coisa num jogo de substituições, se possa substituir as propriedades umas pelas outras, que estas propriedades pertençam à mesma essência da mesma coisa ou que sejam extraídas de essências diferentes. A condição necessária destas extrações e destas trocas é que a essência de um sujeito concreto seja capaz de várias propriedades, depois que entre a essência e os próprios (que são inseparáveis) uma intervenção particular seja possível, no elemento de uma quasesinonímia". Ver em: DERRIDA, Jacques. A mitologia branca: a metáfora no texto filosófico. In: Margens da filosofia. Trad. COSTA, Joaquim Torres e MAGALHÃES, António M. Campinas: Papirus, 1991, pg. 290.

${ }^{191}$ LESTEL, Dominique. Op. cit. pg. 37.

${ }^{192}$ A natureza exemplar da fábula explica o interesse da Retórica grega por esse gênero textual como ferramenta de discurso, explica Maria Celeste Consolin Dezotti: "Os retores gregos foram grandes estudiosos da fábula. Por verem nela um bom recurso para exercitar a competência argumentativa dos futuros oradores, recomendavam o seu uso nas escolas para que o aluno explorasse todas as suas possibilidades significativas. Um desses retores, Theon (séc. I d.C.), formulou a primeira definição de fábula que conhecemos. Diz ele que 'fábula (mythos) é uma fala (logos) mentirosa que retrata uma verdade. ' Essa definição revela que mythos é o nome que os gregos davam à fábula como gênero literário, e revela também que eles tinham plena consciência de que ela era, acima de tudo, fala, discurso, já que, em sua definição, logos é usado como hiperônimo de mythos. Ou seja, é um logos que se realiza por meio de um mythos. "Ver em: DEZOTTI, Maria Celeste Consolin. A tradição da fábula: de Esopo a La Fontaine. Brasília: Editora Universidade de Brasília, São Paulo: Imprensa Oficial do Estado de São Paulo, 2003, pg. 28. 
dos objetos - como os autômatos da literatura fantástica - pela sua capacidade de angariar sentidos à vida humana e de misturar-se em suas comunidades. Diz Lestel: "O animal não é um brinquedo nem um objeto, é antes de tudo uma presença e nisso se encontra sua especificidade. Ele encarna para o homem uma alteridade particular, portadora de sentido"193.

A representação dos animais na literatura revela-se, contudo, complexa e ambígua. Por um lado, afirma Lestel, eles apresentam-se como uma alteridade propiciatória a novos sentidos; por outro, segundo Derrida, precisamente por seu uso ostensivo nos textos literários - ora como metáfora ou como comparação, ora como símbolo ou como figura exemplar -, os animais tornaram-se presenças engessadas e previsíveis, representantes de certos comportamentos e de certas condutas típicas do homem. Derrida propõe-se, por exemplo, o desafio de conceber a individualidade de um gato sem recorrer às figuras felinas presentes na poesia de Baudelaire, de Rilke e de Buber, nas aventuras de Alice e nas fábulas de La Fontaine. Por fim, conclui que o gato que ele tem diante de si sempre será "uma existência rebelde a qualquer conceito"194.

Tendo em vista essas questões sobre a complexidade da representação animal na literatura, avistamos algumas possibilidades críticas a propósito da figura - ou das figuras - de Teleco e de sua trajetória no decorrer da narrativa. Embora inquietante - uma vez que sua própria identidade animal pode ser questionada face sua inconstância e seu comportamento mais próximo do homem do que de qualquer um dos bichos que lhe serviram de disfarce - a presença de Teleco e suas estratégias de aproximação do narrador e, posteriormente, de autoafirmação são reveladoras de sentidos. Suas metamorfoses, aparentemente aleatórias, indicam seus desejos e suas intenções. Elas também dialogam de perto com as imagens tradicionais dos animais que representam aspectos do caráter e das deformações, conforme as considerações de Lestel e de Derrida.

A primeira forma de Teleco, o coelho, edifica a ponte necessária para ganhar a confiança do narrador e assim estabelecer uma amizade. Dócil e inofensivo, como o diminutivo do título já indica, ele coloca-se como promessa de um relacionamento excepcionalmente proveitoso para o solitário protagonista. A figura do coelho, aliás, já traz a promessa em si. Símbolo de multiplicação e de fertilidade em diversas culturas - aspecto que será confirmado, por sinal, em suas metamorfoses -, o coelho sempre foi relacionado à instabilidade, à mudança e ao novo. Teleco, portanto, apresenta-se ao narrador como uma figura previsível e, sobretudo, interpretável, portadora de referências tal qual o gato de Derrida.

${ }^{193}$ LESTEL, Dominique. Op. cit. pg. 41 . Grifo do autor.
${ }^{194}$ DERRIDA, Jacques. Op. cit. pg. 26. 
No verbete a respeito do coelho e da lebre no Dicionário de símbolos, encontramos as razões pelas quais a imagem simbólica desse animal foi cultuada e, ulteriormente, abandonada e, até mesmo, interditada pelos cultos religiosos. A abundância a que ela está relacionada foi a causa de sua predominância e, também, de sua derrocada:

Tudo que está ligado às ideias de abundância, de exuberância, de multiplicação dos
seres e dos bens traz também em si os germes da incontinência, do desperdício, da
luxúria, da desmedida. Por isso o espírito, num dado momento da história das
civilizações, insurge-se contra os símbolos da vida elementar, que gostaria de
controlar ou represar. Receia, com efeito, que essas forças, naturalmente ativas e
positivas na infância do homem e do mundo, destruam, em seguida, o que se edificou
graças a elas. No que se poderia chamar de idades da razão, os povos se levantam
contra as religiões animistas. Tornam então a lebre um tabu. ${ }^{195}$

Teleco perfaz, coincidentemente, sempre movido por sua incontinência física, a mesma trajetória parabólica que parte da promessa positiva do desconhecido e da abundância, atinge o ápice do vigor e da grandiosidade e finda suas transformações de maneira decadente, como a semente de uma potencialidade que não vingou e que não encontra mais terreno no mundo. $\mathrm{O}$ poder simbólico do coelho perde sua validade conforme o mundo se racionaliza e ganha traços automáticos. Lembremos que um pouco antes do primeiro descontentamento do narrador com Teleco, quando este assume a forma de um canguru e passa a chamar-se Barbosa, o animalzinho, entediado com as figuras de bichos ordinários, resolve metamorfosear-se em criaturas desconhecidas ou extintas e desperta uma observação de censura inflamada de seu amigo, a qual Teleco responde: "Sei, mas seria insípido disfarçar-me somente em animais conhecidos"196.

Portanto, ele já fazia transparecer os primeiros indícios de sua sede por complexidade, por mais imprevisibilidade, ao deixar os disfarces óbvios e rastrear novas possibilidades imagéticas. O narrador, por sua vez, não esconde a insatisfação ao ver a emancipação de Teleco, ao perceber que ele está deixando, aos poucos, de ser uma criatura domável e domesticável para tornar-se senhor de si mesmo, o que será consolidado quando ele se deparar com a figura do canguru Barbosa: "Mirei com desprezo aquele bicho mesquinho, de pelos ralos, a denunciar subserviência e torpeza. Nada nele me fazia lembrar o travesso coelhinho"197. Aquilo que era transparente na figura de Teleco torna-se opaco e passa a ser apenas pressentido e intuído por seu amigo. O que mais angustia o narrador com as novas formas de seu amigo está, sobremaneira, na sua incapacidade de interpretá-las, de nomeá-las segundo uma catalogação

195 CHEVALIER, Jean, GHEERBRANT, Alain, com a colaboração de: BARBAULT, André et alii. Dicionário de símbolos: mitos, sonhos, costumes, gestos, formas, figuras, cores, números. Trad. COSTA E SILVA, Vera da, et alii. Rio de Janeiros: José Olympio, 2008, pg. 542. Grifos do autor.

${ }^{196}$ RUBIÃO, Murilo. Teleco, o coelhinho. In: Op. cit. pg. 54.

${ }^{197}$ Idem, ibidem. pg. 55. 
prévia, de inventariá-las - o novo Teleco escapa de suas mãos. O narrador - cuja atividade de lazer preferida é, não por acaso, a coleção de selos - sofre ao ver a impossibilidade de apreender a figura de Teleco, impulso, este, movido pelo complexo adâmico de nomeação, como explica Derrida:

Ele [Deus] deixa Adão, ele deixa o homem, o homem só, Isch sem Ischa, a mulher, ele o deixa gritar livremente os nomes. Ele o deixa, só, dedicar-se às denominações [...] ele criou o homem à sua semelhança para que o homem sujeite, dome, domine, adestre ou domestique os animais nascidos antes dele, e assente sua autoridade sobre eles. Deus destina os animais a experimentar o poder do homem, para ver o poder do homem em ação, para ver o poder do homem à obra, para ver o homem tomar o poder sobre todos os outros viventes. ${ }^{198}$

A perplexidade ante a indefinição animal de Barbosa, cujo corpo híbrido mistura as características físicas do canguru e as comportamentais - mas, também, anatômicas - do homem, além da revolta contra sua indocilidade e sua intratabilidade são o estopim da reação violenta do narrador e do desaparecimento de Teleco. O perfil ordenador e - para retomarmos o termo de Eulálio - dissecador do protagonista, movido pela necessidade de controle e de categorização, não suporta ver Teleco fora do seu campo de influência, como uma marionete lúdica. $\mathrm{O}$ animalzinho passa a ser um enigma para o amigo e este lhe pede para que ele volte a ser "um coelhinho cinzento e meigo, que costumava transformar-se em outros animais"199.

Ao comentar a pertinência de desenjaular os animais de suas categorias taxonômicas na literatura a fim de estender os limites do homem, Álvaro Fernandez Bravo faz coro às considerações de Derrida ${ }^{200}$ acerca dos animais e recorda que qualquer motivação do homem em classificá-los e catalogá-los sempre será uma violência, sobretudo no campo simbólico: “Toda classificação implica uma violência simbólica marcada pela vontade de inserir o múltiplo e o disperso dentro de uma ordem desenhada para apreendê-los e distribuí-los em categorias sempre mais estreitas do que aquilo que designam" 201 . O canguru, no entanto, a despeito de sua similaridade com a anatomia e a postura humanas, não oferece interpretações fáceis. Animal estrangeiro de conformação peculiar, ele não faz parte de um bestiário familiar ao personagem, tampouco ao leitor, posicionando-se como uma figura dificilmente interpretável, que não oferece chaves de leitura nem de análise previamente estabelecidas. Por conseguinte, os animais domésticos e simbólicos do primeiro momento de metamorfoses de Teleco - como o coelho -

\footnotetext{
${ }^{198}$ DERRIDA, Jacques. Op. cit. pg. 37. Grifos do autor.

${ }^{199}$ RUBIÃO, Murilo. Op. cit. pg. 57.

${ }^{200}$ Bravo alude à pertinência do conceito de "animot" cunhado por Derrida, neologismo que mistura o termo "animal" com o termo "mot", cuja tradução para o português é "palavra", e que, no francês falado, tem a mesma pronúncia de "animaux", cuja tradução é "animais". Tal artifício linguístico evocaria, portanto, a pluralidade do extenso mundo animal, refutando a singularidade a que a filosofia e a literatura se habituaram no trato com este outro do homem. Ver em: DERRIDA, Jacques. O animal que logo sou (a seguir). Op. cit.

${ }^{201}$ BRAVO, Álvaro Fernandez. Desenjaular o animal humano. Trad. MACIEL, Maria Esther. In: MACIEL, Maria Esther (org.). Op. cit. pg. 223.
} 
cedem seu lugar a uma efígie enigmática e opaca, acentuando a distância entre o narrador e seu amigo.

Ao mesmo tempo homem e canguru, Teleco deixa de ser o animal fabular, ou seja, o disfarce animal que esconde intenções e deformações humanas, para transformar-se numa criatura híbrida. O bichinho, pouco a pouco, perde o controle dos contornos de suas formas e aproxima-se da quimera, figura mitológica grega a quem Derrida relaciona o par de conceitos "monstruosidade" e "multiplicidade": “da Khimaira, nós sabemos, esse nome próprio designou um monstro que cuspia fogo. Sua monstruosidade devia-se à multiplicidade, precisamente, dos animais, do animot nele (cabeça e tórax de leão, vísceras de cabra, cauda de dragão) "202. No caso de Teleco, a deformidade de seu corpo intensifica-se em seus últimos dias de vida e, apesar de não tomar a forma da quimera mitológica ${ }^{203}$, ele passa a transfigurar-se nos mais diversos corpos.

Derrida retoma, por seu lado, o mito da Quimera para exemplificar a necessidade do homem de triunfar sobre o animal a partir de sua dominação e, posteriormente, de sua domesticação. Belerofonte, algoz da fera, que já havia domado o cavalo alado Pégaso antes do confronto, "representa, é bem conhecido, a figura do caçador", ele é o herói que "segue e persegue o animal" 204 . O mesmo confronto de dominador e dominado estabelece-se, pois, entre Teleco e o narrador, intensificado pela identidade complexa daquele ao transformar-se em animal quimérico. Como afirma Manuela Ribeiro Barbosa, ao analisar o conto Teleco, o coelhinho: "o narrador jamais perde o senhorio sobre a situação: é o dono da história, ao passo que Teleco nunca logra ser reconhecido verdadeiramente como tal"205.

Sobre a morte de Teleco, Ribeiro Barbosa nota que "a derradeira transformação sofremna os dois com o retorno daquele que havia sido enxotado porta afora pela janela. Numa cena evocativa do filho pródigo, um Teleco enfraquecido, vergado pela doença e incapaz de se

\footnotetext{
202 DERRIDA, Jacques. Op. cit. pg. 74.

${ }^{203}$ Eliane Robert Moraes revela que a retomada das figuras mitológicas bestiais pelos surrealistas foi, justamente, um momento de apropriação do imaginário tradicional a respeito das deformações do corpo, mas a partir da dessacralização e da renovação dessas imagens simbólicas: "No capítulo da teratologia, os surrealistas normalmente se rendem aos tipos mais tradicionais da mitologia, fixando-se sobretudo nos seres imaginários como a sereia, o minotauro e a esfinge. Todavia, isso não significa uma retomada do repertório clássico em torno desses mitos: pelo contrário, nessa tópica o poder da referência antiga diminui sensivelmente para dar lugar às imponentes figuras simbólicas que, por seu caráter monstruoso e enigmático, parecem tramar intensos laços com a sensibilidade moderna. A reinvenção dos monstros passa, portanto, pela dessacralização das tradições que os sustentam na qualidade de uma simbólica acabada”. Ver em: MORAES, Eliane Robert. Op. cit. pg. 117.

${ }^{204}$ DERRIDA, Jacques. Op. cit. pg. 78.

${ }^{205}$ BARBOSA, Manuela Ribeiro. Kno Brasil: Kafka, Murilo Rubião e Aníbal Machado. Tese (Teoria da Literatura e Literatura Comparada), Universidade Federal de Minas Gerais, Belo Horizonte, 2014, pg. 130. Disponível em: http://www.bibliotecadigital.ufmg.br/. Último acesso: 19/06/2018.
} 
controlar é recebido por um narrador também transformado"206. A crítica ainda aponta, além da incapacidade de Teleco em falar nos seus últimos momentos, limitando-se a diversos sons animais, a semelhança de seu desfecho com as lendas de outros seres metamórficos: “A perda da fala, mais que indício da animalização, é um passo necessário para o regresso à forma original, a qual, como nas histórias de lobisomem, sempre ocorre com a morte do metamorfoseado 207 ,

De maneira irônica, Teleco aproxima-se do comportamento animal e, consequentemente, perde sua linguagem e seus trejeitos humanos quando está perto de alcançar a desejada figura antropomórfica - que se desvelará como o cadáver terrificante de uma criança. A ironia faz-se ainda mais forte no movimento final do conto, quando a última forma de Teleco nós é revelada. O animalzinho transforma-se num menino encardido e raquítico, tal qual a figura que o narrador fez de Teleco no momento em que este lhe requisita um cigarro e atrapalha seus devaneios diante do mar. Retornando ao conto, notamos que o herói já estava pronto a chamar a polícia ou a enxotar "com um pontapé” quem o importunava pedindo-lhe um cigarro, pensando tratar-se de um "moleque", de um "importuno pedinte" que incomodava sua solidão e suas "ridículas lembranças"208.

Como afirmamos anteriormente, a figura do coelho foi a ponte necessária para estabelecer a amizade entre Teleco e o narrador, cuja personalidade egoísta, individualista, ciumenta, autoritária e conservadora jamais aprovaria um relacionamento que não lhe trouxesse senão encantamentos fáceis e, sobretudo, proveitosos. O tédio desencadeado em Teleco devido a tal condição, como vimos com Schwartz, leva-o ao disfarce de Barbosa, presença que revelará, por sua vez, os ressentimentos e a inflexibilidade do narrador, que reprova o comportamento libidinoso e farrista do homem-canguru, ao mesmo tempo em que deseja estar na posição do amigo e nos braços de sua namorada Tereza. Não por acaso, após o rompimento entre os dois, será sob a forma de um cão que Teleco tenta resgatar a amizade com o protagonista. Tal qual o coelho, o cachorro também porta, simbolicamente, diversas qualidades positivas que o homem enxerga e define a partir de si mesmo e atribui a este outro animal. Como afirma Maria Esther Maciel ao avaliar a presença corrente dos animais na literatura, o cão "é o animal que oferece as conexões mais primárias entre os mundos humano e animal, visto que sua existência é impensável fora dos domínios humanos"209.

\footnotetext{
${ }^{206}$ Idem, ibidem. pg. 128.

${ }^{207}$ Idem, ibidem.

${ }^{208}$ RUBIÃO, Murilo. Teleco, o coelhinho. In: Op. cit. pg. 52

${ }^{209}$ MACIEL, Maria Esther. Narrativas da animalidade. In: Literatura e animalidade. Rio de Janeiro: Civilização Brasileira, 2016, pg. 60.
} 
Uma vez restabelecida a amizade entre os dois, Teleco, tomado pela melancolia em razão da ausência de Tereza, não consegue mais controlar seus disfarces animais e seus contornos físicos perdem a rigidez, originando seres quiméricos irreconhecíveis. Sobre as últimas metamorfoses do bichinho, Jorge Schwartz reitera o raciocínio interpretativo de Davi Arrigucci Jr. que, por sua vez, retoma o pensamento filosófico sartriano ${ }^{210}$ : "Nessa metamorfose às avessas, onde o animal concentra todas suas forças para se assemelhar ao homem, a inutilidade dos esforços (os meios) se conjuga com a inutilidade dos fins (ser homem), projetando-se ambas no mísero resultado de uma criança encardida e sem vida" ${ }^{211}$.

Schwartz considera, pois, a última imagem de Teleco uma consequência de suas tentativas infrutíferas de transformar-se em homem. À vista disso, a criança morta seria o resultado da soma da "inutilidade dos esforços" com "inutilidade dos fins". Teleco, no entanto, ao invés de estar lutando para fixar-se sob a forma humana, parece estar perdendo, com efeito, sua capacidade de metamorfosear-se. Antes de ser uma punição por sua conduta, a sua derradeira imagem desponta da falência total de seus aparatos espetaculares e ilusórios, que já mostravam sinais de abatimento ao longo de sua convalescença. Como uma máquina em pane, o cadáver da criança apresenta aquilo que restou de uma criatura que perdera seus encantos, sua funcionalidade e está completamente nua. Quando já não consegue disfarçar-se sob a previsibilidade de algum animal familiar, pronto para encenar o papel de amigo agradável e entreter os outros com seus malabarismos e picardias, ou, ainda, brincar de homem adulto sob a forma de um canguru, ganhando a vida como mágico de circo, Teleco revela sua última - e terrivelmente real - máscara, aquela que o narrador, desde o início, pressentiu como possibilidade, mas que logo desprezou. Isso explicaria o fato de Teleco, desiludido com a vida, perder sua maestria em representar personagens humanos (embora sob a forma de bichos) e aproximar-se do comportamento animal (agindo, de fato, como um) pouco antes de desnudarse como criança.

Assim como no conto Os dragões, em que a bestialidade humana aniquila a vida das criaturas que pressupomos a priori bestiais, os limites entre o homem e o animal também são opacos em Teleco, o coelhinho. Se, por um lado, os animais agem como homens, por outro lado, os homens aproximam-se do comportamento presumivelmente animal. Nisso há alguma semelhança entre a narrativa de Rubião e certos contos de Franz Kafka protagonizados por homens-animais. Como aponta Márcio Seligmann-Silva, o autor checo quer mostrar, no conto Um relatório para uma academia - por sua vez, também uma história sobre domesticação -,

\footnotetext{
${ }^{210}$ Ver nota de rodapé 118.

${ }^{211}$ SCHWARTZ, Jorge. Op. cit. pg. 52.
} 
que "o animal é o limpo, os homens são os sujos: Kafka brinca de amarelinha na estrada tortuosa da 'evolução' dita humana, ou ainda: ele joga lego com as peças da Criação"212.

Machado de Assis foi outro autor que, por meio do ponto de vista animal, escreveu alguns de seus contos e de suas crônicas. Maria Esther Maciel - ao comentar a presença animal na prosa machadiana - salienta o uso paródico que o escritor fez da estrutura tradicional da fábula em textos como, por exemplo, Crônica dos burros, na qual nos é narrada a história da escravidão desses animais: “A diferença com relação à fábula tradicional é que os animais, neste caso, não são antropomorfizados nem estão a serviço da edificação humana, mas aparecem como animais-animais que expressam o que o autor imagina que eles falariam se pudessem fazer uso da linguagem verbal" 213. A paródia das fábulas feita por Machado, longe de intencionar uma moralidade edificante para o leitor, deseja, contrariamente, criticar e satirizar as correntes filosóficas humanistas de seu tempo, o pensamento cartesiano que rebaixava os animais a criaturas de segundo nível e o positivismo científico que excitava seus contemporâneos. Seu propósito fica evidente no conto Ideias de canário, que acompanha os encontros e as conversas do pássaro com um cientista: “Ao atribuir ao pássaro uma fala humana, Machado mais uma vez se vale dos recursos do antropomorfismo, próprios da fábula. No entanto, o que ele faz é usar, paradoxalmente, o antropomorfismo contra o humanismo" 214.

Em Rubião, porém, as figuras animalescas pressupõem certas intenções dos personagens que as colocam mais como parte de um corpo complexo, ambíguo e duplo do que como presenças aguda e unicamente animais. Longe da experiência entranhada e profunda que encontramos em outros autores, a metamorfose animal em Rubião será sempre horizontal. Sobre a multiplicidade de metamorfoses, Vera Lúcia Andrade e Wander Melo Miranda afirmam: "O sentido vazio da vida e do texto, inutilmente preenchido pelas transmutações ocorridas, reforça a impotência subjacente a toda busca de conhecimento, num mundo condenado ao malogro do saber e do desejo" 215 . Os animais, portanto, assim como as outras metamorfoses, representariam uma potência que revela o desejo por conhecimento e por sentido, uma possibilidade - destinada ao malogro - de chacoalhar a frivolidade do mundo.

Entretanto, as formas animais não são tão arbitrárias como apontam os críticos e, como observamos na trajetória de Teleco, são fundamentais para estabelecer as ligações entre

\footnotetext{
${ }^{212}$ SELIGMANN-SILVA, Márcio. Mal-estar na cultura: corpo e animalidade em Kafka, Freud e Coetzee. In: MACIEL, Maria Esther (org.). Pensar/escrever o animal: ensaios de zoopoética e biopolítica. Op. cit. pg. 151. ${ }^{213}$ MACIEL, Maria Esther. Narrativas da animalidade. In: Op. cit. pp. 74-75.

${ }^{214}$ Idem, ibidem. pg. 79.

215 ANDRADE, Vera Lúcia, MIRANDA, Wander Melo. As visões do invisível. In: Jornal Estado de Minas. Murilo Rubião, o ex-mágico aos 70 anos. Belo Horizonte, 31 de maio de 1986. Disponível em: http://www.murilorubiao.com.br. Último acesso: 19/06/2018.
} 
personagens, além de indicarem suas intenções, seus desejos e suas condições. O coelho, o canguru e o cachorro assinalam, tal qual as máscaras do teatro, estados e passagens de humor de Teleco e são - apesar das falhas - a ligadura necessária entre ele e o narrador. Neste caso, as formas animais foram os disfarces necessários para Teleco aproximar-se e imiscuir-se na realidade íntima do narrador. Por outro lado, o disfarce animal também pode ser, em Rubião, uma iniciativa de afastamento do convívio dos homens e, por conseguinte, de total isolamento.

\section{Alfredo e o lobisomem}

Após se irritar com as queixas e com as superstições de sua esposa Joaquina, apavorada com os gemidos de uma fera desconhecida que ameaçava descer o vale - e que ela acreditava tratar-se de um lobisomem -, o narrador-protagonista do conto Alfredo, Joaquim, dispõe-se a solucionar o caso e inicia a investigação. A busca dá-se rapidamente e a criatura tão temida não passa, afinal de contas, de um dócil e indolente dromedário, que logo desperta ternura no caçador. Depois de algumas tentativas de comunicação, o narrador reconhece no animal seu irmão Alfredo, de quem se separara havia muito tempo. O homem metamorfoseado em dromedário revela-lhe que sua transformação veio do desejo de escapar de seus semelhantes humanos. De início, transformou-se em porco, mas a vida coletiva deste animal não lhe agradou. Decide, então, metamorfosear-se no próprio verbo resolver, resoluto de que ele, por certo, resolveria os problemas de sua vida:

\footnotetext{
De início, Alfredo pensou que a solução seria transformar-se num porco, convencido da impossibilidade de conviver com seus semelhantes, a se entredevorarem no ódio. Tentou apaziguá-los e voltaram-se contra ele. Transformado em porco, perdeu o sossego. Levava o tempo fossando o chão lamacento. E ainda tinha que lutar com os companheiros, sem que, para isso, houvesse um motivo relevante. Imaginou, então, que fundir-se numa nuvem é que resolvia. Resolvia o quê? Tinha que resolver algo. Foi nesse instante que lhe ocorreu transmudar-se no verbo resolver. E o porco se fez verbo. Um pequenino verbo, inconjugável. Entretanto, o verbo resolver é, obviamente, a solução dos problemas, o remédio dos males. Nessa condição, não teve descanso, resolvendo assuntos, deixando de solucionar a maioria deles. Mas, quando lhe pediram que desse um jeito em mais uma briga familiar, recusou-se. ${ }^{216}$
}

Frustrado com a incapacidade do verbo, transforma-se, enfim, num dromedário, convencido de que o único sentido possível para a vida é beber muita água. O narrador, por sua vez, não demonstra nenhum espanto ao escutar o relato das insólitas mutações de seu irmão e, junto dele, leva-o para casa. Sua esposa não aceita a presença do animal e expulsa os dois, fazendo com que o narrador abandone essa região, sua antiga vida e seu povoado, para peregrinar por terras estranhas ao lado de Alfredo: "Perdera mais uma jornada ao procurar nas

\footnotetext{
${ }^{216}$ RUBIÃO, Murilo. Alfredo. In: Op. cit. pg. 101.
} 
montanhas refúgio contra as náuseas do passado. De novo, teria que peregrinar por terras estranhas. [...] E agora sem a esperança de um paradeiro" 217.

Há no conto, portanto, de maneira indireta, a confrontação entre dois seres metamórficos: de um lado o suposto lobisomem, de outro o personagem Alfredo. De início, a figura do lobisomem aparece como possibilidade de ameaça para o vilarejo habitado pelo narrador. A partir da crença de sua esposa Joaquina nesse ser lendário, monstro presente em todo o imaginário ocidental e amplamente encontrado na tradição oral das histórias fantásticas, pode-se conjecturar que estamos diante de uma história há muito vivida, no tempo distante e irreal dos contos de fada, das fábulas e das lendas. A quase ausência de marcas espaciais nas descrições do conto reforça essa atmosfera vaga da narrativa maravilhosa. Tem-se acesso a apenas algumas referências vagas que se contrapõem - o povoado, o vale, a planície e a serra. Os deslocamentos do narrador de um ambiente para outro, do seguro para o desconhecido, do urbano para o selvagem, além da possível presença de uma besta lendária amedrontadora, arrematam o clima narrativo feérico ${ }^{218}$.

Dessa forma, a escolha do folclore como explicação para os estranhos lamentos escutados pelo povoado é expressada pelos temores da esposa do narrador. Além disso, o sentimento de ameaça que toma conta da cidadezinha retoma, com efeito, a atmosfera das histórias do homem que se metamorfoseia em lobo. Curiosamente, a razão do narrador para deixar sua casa e buscar a fonte dos gritos não vem de sua crença em lobisomens ou de um possível desejo por lançar-se em busca de atos heroicos, deslocando-se da cidade para a floresta, ou, ainda, a atração pelo desconhecido típica dos contos de fada. Pelo contrário, ele deseja provar a si mesmo, à sua mulher e aos outros habitantes do povoado que esse tipo de personagem folclórico não existe, que não passa de um fruto da imaginação coletiva e de que há, decerto, uma explicação mais plausível e mais racional para esse contratempo. Em suas próprias palavras:

A nossa primeira desavença conjugal surgiu quando a fera ameaçou descer ao vale. Joaquina, a exemplo da maioria dos habitantes do povoado, estava preocupada com os estranhos rumores que vinham da serra. Inicialmente pretendeu incutir-me uma tola superstição. Ri-me da sua crendice: um lobisomem?! Era só o que faltava! Ao verificar que ela não gracejava e se punha impaciente com o meu sarcasmo, quis explicar-lhe

\footnotetext{
${ }^{217}$ Idem, ibidem. pg. 103.

${ }^{218}$ Pensamos aqui nas considerações psicanalíticas de Bruno Bettelheim a respeito dos contos de fada João e Maria e Chapeuzinho Vermelho, em que ele ressalta a importância, dentro desse gênero narrativo, do deslocamento entre a segurança do lar e o desconhecido da floresta como símbolo do aprendizado, do amadurecimento e do crescimento da criança. O bosque misterioso é, em ambos os contos, a figuração da aventura, do proibido e do desejo - seja representado pelo lobo mau, seja por uma casa de doces. Murilo Rubião faz uso, portanto, da mesma estrutura consagrada de início dos contos de fada para começar seu conto Alfredo. Ver em: BETTELHEIM, Bruno. A psicanálise dos contos de fada. Trad. CAETANO, Arlete. 7. ed. São Paulo: Editora Paz e Terra, 1996. Pp. 195219.
} 
que o sobrenatural não existia. Os meus argumentos não foram levados a sério: ambos tínhamos pontos de vida bastante definidos e irremediavelmente antagônicos. ${ }^{219}$

Esse conflito estabelecido entre o ceticismo do narrador e a credulidade de sua esposa representante do senso comum, da opinião majoritária do povoado - acaba reforçando o deslocamento do protagonista ante a sua realidade, forçando-o a deixá-la. Seu desprezo pelas crendices e pelas superstições de seus conterrâneos motiva seu afastamento e culminará, após o encontro com seu irmão Alfredo, no abandono definitivo de suas raízes e no início de uma vida nômade juntos, sem perspectiva de assentamento.

Eduardo Jorge, ao falar das origens da lenda do lobisomem e de sua presença na literatura, define a lenda da criatura metamórfica como um exemplo de história que, dentro da tradição oral, se volta para a presença do inquietante, do Unheimliche freudiano, daquilo que deveria permanecer escondido, mas que, eventualmente, vem à tona. Segundo o crítico: "Diante da presença de corpos híbridos de homens e animais, existe um incômodo que está na ordem de algo que é familiar, mas ao mesmo tempo estranho, como se algo de inquietante residisse nessa familiaridade" ${ }^{220}$. A lenda do lobisomem exemplifica, justamente, o imaginário coletivo apontando para algo arcaico, que se recusa a esconder-se, que desperta tanto a abjeção quanto o desejo e pode despontar a qualquer momento: "É nas leituras e nas releituras que as lendas se constituem como uma tradição alterada, mas que mantém algo que permanece como se tais leituras trouxessem à tona a fina película que mantém o arcaico pulsante"221.

Assim, Jorge mostra que o lobisomem se configura como uma constante ameaça para o homem por ser um símbolo da hibridez - da perda das fronteiras entre o ser humano e o animal -, ainda mais ao considerar-se que ele, em grande parte de suas transfigurações, caracteriza-se como um lobo antropomórfico. No entanto o pesquisador aponta para a possibilidade literária originada a partir desse apagamento dos limites, lugar onde a ciência e o conhecimento não tocam. Nas palavras de Jorge:

A animalidade, portanto, atuaria em um limite, valendo-se da fina película que reveste o arcaico, emoções originais (o fantasma do primitivo reprimido) e uma precariedade do corpo a partir de sua fisiologia. Diante de tais fragilidades, tem-se ainda a incerteza do conhecimento. Porém, esses aspectos, se lidos e observados como potência e devir, seriam uma abertura para a experiência literária, em torno dessa abertura a presença inquietante de outros corpos (híbridos, metamórficos) atuaria em uma oscilação entre medo e desejo, enfim, uma espécie de marca do maravilhamento. ${ }^{222}$

\footnotetext{
${ }^{219}$ RUBIÃO, Murilo. Alfredo. In: Op. cit. pg. 98.

${ }^{220}$ JORGE, Eduardo. Lobisomem, sem ameaças. In: MACIEL, Maria Esther (org.). In: Pensar/escrever o animal: ensaios de zoopoética e biopolítica. Op. cit. pg. 177.

${ }^{221}$ Idem, ibidem. pg. 180.

${ }^{222}$ Idem, ibidem. pg. 178.
} 
Fazendo coro às reflexões de Jacques Derrida a respeito da animalidade - em que a poesia seria o único meio humano possível para aproximar o homem do animal, separados por uma distância abissal provocada pelo logos - Jorge dá exemplos de como a figura do lobisomem foi representada na literatura contemporânea, a fim de provar que a metamorfose e que o ser híbrido, o devir animal, podem questionar, justamente, os limites do próprio ser humano, dos seus saberes e do seu conhecimento. Ela marca uma área turva, onde a abjeção, o medo, o desejo e a vontade se combinam para revelar sensações primitivas encobertas pela racionalidade.

Todavia, o narrador de Alfredo recusa a possibilidade da existência do lobisomem, desse ser sobrenatural já consolidado na fantasia humana. Seu ceticismo faz lembrar, justamente, os heróis da literatura fantástica do século XIX que terão sua racionalidade abalada por um acontecimento insólito, pelo aparecimento do inquietante, de onde surgirá a hesitação, por parte do narrador e por parte do leitor, entre uma explicação científica ou sobrenatural. Ainda mais se considerarmos o fato de essas figuras terem contribuído para o surgimento da narrativa fantástica oitocentista e de nela terem se manifestado recorrentemente. ${ }^{223}$

Como já descrevemos, essa confrontação com o sobrenatural também aparece no conto Alfredo, no momento em que o protagonista encontra seu irmão transformado em dromedário. De maneira surpreendente para o leitor, porém, o narrador - tão descrente em relação à existência de lobisomens - não se espanta com o fato de seu irmão ser agora um dromedário, acredita nessa transformação e não esboça sentimentos de incredulidade ante a possibilidade de existência de um ser metamórfico, precisamente aquilo que ele negava momentos antes. Além disso, não o surpreende o relato de Alfredo sobre as suas outras transformações, como a mutação em porco e no verbo resolver. A partir daí o conto altera o tom e rompe com sua atmosfera feérica; enfim, com sua estrutura de conto de fadas. A falta de surpresa do narrador revela que o seu descontentamento inicial com as superstições de seu povoado, com o fato de elas acreditarem em lobisomens, não diz respeito à sua descrença no sobrenatural, mas, sim, à crença supersticiosa em si. Seu problema relaciona-se com as velhas histórias, com as lendas

\footnotetext{
${ }^{223}$ Segundo Louis Vax, esse sentimento de inquietação, presente nas lendas e nas histórias contadas à noite em volta da fogueira, está na origem da literatura fantástica iniciada no século XVIII e consolidada no século XIX. Dessa forma, as figuras já conhecidas da tradição oral, cujas histórias e cujos hábitos já eram familiares a todos, serão reaproveitadas pela literatura como motivos e temas recorrentes. Vax mostra-nos, por exemplo, como o vampiro e o lobisomem foram bastante utilizados pelos escritores desse período, justamente, por seu caráter antissocial e por sua tendência ao isolamento, natureza que já lhes era própria desde seu surgimento num tempo remoto e impreciso: « Vampire et loup-garou, d'ailleurs, sont cousins germains. Des hommes dégradés. Des êtres humains chez qui le spirituel a régressé vers le psychique. L'un boit le sang des autres pour prolonger égoïstement sa vie ; l'autre libère la bête assoupie en lui. Tous deux renoncent à la communauté des hommes pour la solitude égoïste des fauves. Deux anthropophages qui, violant le même tabou, inspirent la même horreur ». Ver em: VAX, Louis. La séduction de l'étrange. Paris: Quadrige/PUF, 1987, pp. 57-58.
} 
que ainda são contadas pelos habitantes do povoado e que lhe parecem ultrapassadas, incompatíveis com a sua realidade, e que, por fim, despertam seu desprezo.

Efetivamente, as metamorfoses de Alfredo pouco se assemelham às mutações de um ser lendário como o lobisomem. Elas respondem ao seu livre arbítrio, realizam-se quando Alfredo quer que elas se realizem e podem assumir formas bastante diversas. Elas não necessitam de uma maldição ou de um feitiço para acontecerem, elas simplesmente acontecem. Se na história do lobisomem há uma explicação para a metamorfose que, apesar de ter múltiplas origens e ser intrincada e pouco elucidativa, justifica sua natureza ${ }^{224}$, o mesmo não se pode dizer de Alfredo, que se transforma pela vontade de se transformar, de escapar da forma humana, embora continue a pensar como homem. Essa voluntariedade metamórfica é comentada por Rachel Jardim que, ao invés de contrapor Alfredo à figura do lobisomem, confronta-o com os personagens de Kafka: “o personagem, Alfredo, tenta a metamorfose, numa tentativa lúcida de fugir aos conflitos humanos. Em Kafka, pelo contrário, a metamorfose é sempre imposta ao personagem, que não a procura, mas a aceita como inevitável"225.

Esse corpo híbrido, aliás, define-se como conflito e frustração do personagem, pois ele - ao modificar apenas a sua forma, sem modificar a sua essência - vê-se condenado a uma busca vã por outra existência, já anunciada pela epígrafe do conto, retirada dos Salmos: "Esta é a geração dos que o buscam, dos que buscam a face do Deus de Jacó". Um dos sintomas de tal condenação está na incapacidade de resolução do verbo "resolver", outra alusão à Bíblia encontrada no conto. A trajetória do personagem metamórfico parodia o percurso de Cristo, como é notado por Schwartz ${ }^{226}$, retomando seus passos pela via oposta: Alfredo desfaz-se de seu corpo e transforma-se em verbo a fim de se isolar do resto dos homens, contrariando o caminho de Jesus, que se faz carne, justamente, para andar no meio deles e espalhar a palavra.

\footnotetext{
${ }^{224}$ Eduardo Jorge comenta a multiplicidade de histórias da tradição oral - em diversas regiões do planeta, não somente no Ocidente - a respeito de uma criatura híbrida de homem e de lobo. Já na História natural, de Plínio, o Velho, há comentários acerca da crença de determinados povoados da Península Itálica de um homem capaz de transformar-se em lobo. O próprio naturalista romano reconhece, por sua vez, que tais histórias já são muito antigas e que não devem ser tomadas a sério. Jorge também mostra a importância da figura do lobo para Derrida em seus estudos sobre o animal: "Se, para Plínio, as versões da transformação de homem em lobo e vice-versa já tinham uma tradição secular, hoje tais histórias estão mais do que multiplicadas, encontrando-se desde os registros na tradição clássica grega, na própria História natural, de Plínio, o Velho, em Heródoto, na África, na Ásia e no Brasil, para citar brevemente uma lista que se rende ao et cetera. [...] Em La bete et le souverain, Jacques Derrida elege uma verdadeira biblioteca de lobos, percorrendo "O homem dos lobos", de Freud, o licantropo, o devirhomem do lobo ou o devir-lobo do homem, de Deleuze e Guattari”. Ver em: JORGE, Eduardo. Op. cit. pp. 180 181.

${ }^{225}$ JARDIM, Rachel. Realidade, fantasia. In: $O$ Globo. Rio de Janeiro. 22 de outubro de 1978. Disponível em: http://www.murilorubiao.com.br. Último acesso: 19/06/2018.

${ }^{226}$ SCHWARTZ, Jorge. Op. cit. pg. 44.
} 
O próprio verbo "resolver" não se mostra capaz, portanto, de diminuir a angústia de Alfredo. Em seu mundo - onde não há a menor possibilidade da existência de um lobisomem - também não há, consequentemente, passes de mágica, encantamentos ou abracadabras que aliviem o peso de sua existência e tampouco um enigma a ser resolvido que o salvará de seu desfecho trágico. A realidade exageradamente insólita de Alfredo já perdeu, contudo, qualquer sinal de magia e está totalmente descolada das crenças supersticiosas e das lendas folclóricas, embora os moradores da cidadezinha ainda creiam nelas. Dessa forma, para Schwartz, Joaquim e Alfredo estão condenados a errar pelo mundo sem livrarem-se de sua condição humana:

\begin{abstract}
[...] as personagens Joaquim/Alfredo simbolizam o caráter errático do homem no mundo. Joaquim, que mora no vale, dirige-se à serra respondendo ao apelo de seu irmão Alfredo metamorfoseado em fera. Lá eles relembram o passado e constatam a inutilidade da saída da planície, lugar de origem e ponto de partida em busca da felicidade. Juntos descem novamente ao vale e, após desentendimentos com Joaquina, esposa de Joaquim, voltam para a serra. Uma vez lá, e novamente desiludidos, partem à procura de outros lugares onde pudessem achar a felicidade. Verdadeiros peregrinos do mundo, Joaquim e Alfredo tornam-se irmãos, no percurso e no sentimento, de sua condição humana [...] Alfredo sofre o processo inverso de Teleco, que tudo faz para tornar-se homem. Suas metamorfoses conotam o desejo de afastamento dos homens, mas, nem como dromedário, nem como porco, nem como verbo, a personagem Joaquim/Alfredo consegue alienar da condição humana. ${ }^{227}$
\end{abstract}

Tal ruptura está marcada pela oposição entre as duas criaturas animais que dominam o conto - o lobisomem e o dromedário. Logo, a diferença entre ambos ressalta a diferença irremediável que existe entre os dois irmãos e o povoado e que condena aqueles ao desterro. Se, por um lado, temos a presença de uma criatura metamórfica que alude às forças arcaicas das lendas da tradição oral e amplamente conhecida, por outro, temos um animal anódino, descontextualizado, incompatível com o meio e a sociedade que o circundam e sem qualquer traço simbólico decifrável.

A figura do dromedário - que remete ao deserto e, consequentemente, às narrativas da tradição árabe, como as Mil e uma noites - desloca-se para uma cidadezinha interiorana cercada por planícies, vales e serras, hábitat costumeiro dos lobisomens. Assim como o canguru Barbosa foi o disfarce excêntrico que Teleco encontrou para firmar-se numa identidade quase humana, o dromedário apresenta-se como o último recurso de Alfredo para consolidar seu afastamento dos homens, sua recusa à vida em coletividade - reforçada pela experiência entre porcos - e, portanto, abraçar sua natureza díspar. Há uma similitude na escolha de ambos os personagens murilianos em sua busca por autoafirmação a partir de uma forma animal tão insólita quanto sua própria capacidade de metamorfosear-se. O rompimento com as figuras usuais dos bestiários literários, cuja presença pode ser facilmente decifrada do ponto de vista simbólico -

\footnotetext{
${ }^{227}$ Idem, ibidem. pp. 44-45.
} 
uma vez que tanto o coelho quanto o porco são animais social e culturalmente familiares marca uma espécie de rito de passagem, de emancipação de ambos. O canguru surge como possibilidade de Teleco libertar-se de sua subserviência ante os caprichos voyeurísticos do narrador do conto, já o dromedário sublinha o rompimento de Alfredo com os outros homens e o seu afastamento social.

O paralelo estabelecido entre o lobisomem e o dromedário reforça, em contrapartida, um passo ainda mais largo de Alfredo para fora dos limites da vivência entre os homens e de tudo que lhes concerne. Como vimos anteriormente com Eduardo Jorge, a figura híbrida do homem-lobo esconde, por baixo de seu corpo híbrido, um desejo, uma pulsão ou um instinto arcaizante rebuçado pela vida em sociedade. A lenda do lobisomem seria - assim como grande parte das lendas - um resquício enfraquecido dessa ancestralidade do homem que pressentimos como inquietantemente familiar. Daí o uso que Jorge faz do conceito freudiano de Unheimliche. Além do lobisomem, também o vampiro, a mula-sem-cabeça e tantas outras criaturas híbridas do folclore seriam o limiar entre o homem e os outros animais, entre a vida social e o isolamento, entre a razão e o desconhecido.

A transfiguração do homem em animal como uma maneira de libertação desses instintos reprimidos reitera-se tanto nas histórias da tradição oral quanto na literatura escrita e, também, nas discussões filosóficas. O corpo humano visto como aprisionamento das forças e dos poderes animais que lutam para alcançarem a liberdade pode ser encontrado na imagem que Georges Bataille criou, por exemplo, em seu artigo sobre a metamorfose. O homem, segundo o filósofo francês, é "uma prisão de aparência burocrática" e a metamorfose é uma "violenta necessidade" que se relaciona "com cada uma de nossas necessidades animais" 228 . Dessa forma, Bataille inverte os sinais comumente atribuídos aos homens e aos animais - o corpo humano racional e controlado assinala-se negativamente, por ser um empecilho às possibilidades da experiência animal que, por sua vez, faz-se positivamente necessária.

Alfredo, no entanto, escolhe o dromedário como seu novo corpo. Distante da grandiosidade representada pelo lobisomem - cuja hibridez remete à junção das forças do homem e do animal e é o fator, com efeito, que justifica seu poder e o seu fascínio para diversas culturas em que ele está prefigurado - o personagem muriliano escolhe um animal manso e extravagante ao abdicar, em definitivo, da forma humana. O lobisomem, conforme vemos no próprio nome da criatura, não se priva da sua condição de homem e revela-se, quando muito, como uma revolta íntima do animal que ainda o molesta por dentro, embora incapaz de abrir

\footnotetext{
${ }^{228}$ BATAILLE, Georges. Métamorphose. In: Euvres complètes - tome I. Paris: Gallimard, 1970, pp. 208-209.
} 
mão de sua identidade e de seu corpo humanos e de estar fadado a eles regressar. Apesar de ser visto como uma maldição em muitas vertentes da lenda, o lobisomem caracteriza-se, em todas elas, como uma potência, como um poder escondido na aparente fragilidade da anatomia do homem.

O dromedário, portanto, apresenta-se a Alfredo como possibilidade de exteriorizar o oposto disso - o animal das imensidões e do isolamento do deserto simboliza sua postura indiferente, quase estoica, face ao mundo. Logo, o irmão do protagonista escolhe, entre todas as criaturas animais, aquela que refletiria, de alguma maneira, seu próprio estado de espírito à guisa de pensar - ou de não pensar - sobre sua situação. Schwartz lembra, porém, que os lamentos sonoros do dromedário chamam seu irmão à floresta e, portanto, ainda mantêm um vínculo frágil com o povoado e seus habitantes: "Este chamado é o imperativo que o faz participar, de algum modo, do seu meio circundante"229. Malgrado seu comportamento dócil, Alfredo lembra o lobisomem pela vocação à marginalidade social, por sua vontade de estar na periferia das aglomerações humanas e ser delas, ao mesmo tempo, integrante e outsider. Todavia, enquanto o lobisomem deseja ser um elemento de ameaça aos outros homens, Alfredo encaixa-se nessa dinâmica como elemento estrangeiro - tal qual o dromedário - e precisa estar junto deles tão-somente para servir ao seu irmão e à narrativa como um novo e estranho ponto de vista, além da vantagem de lembrar a si mesmo, a partir do elo que ainda o une aos seus antigos conterrâneos, as razões de sua debandada.

No momento em que conhece sua cunhada Joaquina, Alfredo faz uma estranha observação ao reparar na heterocromia ocular da mulher. Colocação estranha, também, por ser proferida no meio de uma briga tensa entre ela e seu marido Joaquim: "Muito interessante. Esta senhora tem dois olhos: um verde e outro azul" ${ }^{\text {230 }}$. Além da falta de tato e de decoro de Alfredo ao abordar tal assunto no meio de uma discussão acalorada do casal - o que reforça sua inabilidade ao lidar com outras pessoas e sua personalidade antissocial -, a construção do seu comentário, em si, já soa bastante inabitual. Ao invés de usar a estrutura corrente e dizer que a mulher tinha "um olho de cada cor", Alfredo afirma que ela tem dois olhos para depois relatar a diferença cromática. Ora, possuir dois olhos não deveria despertar surpresa alguma, uma vez que essa característica está dentro do padrão de normalidade esperado no corpo humano - o fato que os diferenciavam, evidentemente, era a heterocromia. No entanto, a atenção do irmão de Joaquim recai, além das cores, para a existência de dois olhos no rosto da cunhada.

\footnotetext{
${ }^{229}$ SCHWARTZ, Jorge. Op. cit. pg. 45.

${ }^{230}$ RUBIÃO, Murilo. Alfredo. In: Op. cit. pg. 100.
} 
A partir desse suposto deslize discursivo de Alfredo, todo o sentido da frase parece, por sua vez, deslizar. O fato do personagem ressaltar a presença de dois olhos em Joaquina levanos a entender essa palavra não no seu sentido literal, mas como figura metonímica indicadora de um segundo sentido. De fato, quando ele profere a oração "esta senhora tem dois olhos", reforçada pela expressão "muito interessante", compreendemo-la como se quisesse dizer algo mais. Os olhos, portanto, quereriam indicar a palavra "olhares", ressaltando a desconfiança de Alfredo em relação à mulher de Joaquim. Sabendo da importância dos olhos dentro da prosa muriliana - Teleco, por exemplo, conquista o narrador devido aos seus "olhos mansos e tristes"231; Tereza o manipula com seu "olhar súplice"232; o terrível canguru Barbosa esconde seus olhos "por trás de uns óculos de metal ordinário"233; Joaquim aproxima-se do dromedário Alfredo ao ver "a ternura que emanava dos seus olhos infantis" $234_{-}$, somos ainda mais instigados a analisar o significado do comentário de Alfredo.

Efetivamente, as ações de Joaquina corroborarão seu caráter ambíguo e, até mesmo, cruel. Recusando-se a aceitar a presença do dromedário em sua casa, ela expulsa seu marido e seu cunhado de casa de maneira brutal. Seus olhos heterocromáticos parecem revelar, com efeito, sua personalidade dúbia - por trás de uma mulher aparentemente simples do campo esconde-se um espírito mesquinho e impiedoso. O fato de, em Murilo Rubião, o olhar sempre refletir aquilo que se esconde sob as intenções superficialmente expressas dos personagens, coloca os olhos de cores diferentes como indício de obscuridade do caráter de Joaquina. O comentário de Alfredo, portanto, serve como revelação das duas faces de sua cunhada, desconcertando-a ao ponto de ela dar fim ao seu casamento.

Em virtude da sagacidade e da intuição do dromedário, aparentemente alheio aos homens e a tudo que lhes concerne, tanto Joaquim quanto o leitor acessam informações que permaneceriam inacessíveis. Tais considerações precisam ser despertadas a partir, justamente, de um ponto de vista descolado da cotidianidade dos fatos, estrangeiro a essa realidade automática e que consiga enxergar para além do aparentemente óbvio - o dromedário mostrase como o único capaz de vislumbrar a verdade que está diante de todos. Não por acaso Alfredo logra romper com a automaticidade da vida de seu irmão. A partir de sua posição social e de seus comentários desconcertantes, o dromedário tira-o do vilarejo que tanto o contrariava devido sobretudo à sua credulidade e à sua supersticiosidade - para levá-lo a uma vida nômade

\footnotetext{
${ }^{231}$ RUBIÃO, Murilo. Teleco, o coelhinho. In: Op. cit. pg. 52.

${ }^{232}$ Idem, ibidem. pg. 56

${ }^{233}$ Idem, ibidem. pg. 54.

${ }^{234}$ RUBIÃO, Murilo. Alfredo. In: Op. cit. pg. 99.
} 
a dois. O desfecho, portanto, indica a reunião de Joaquim com seu duplo ${ }^{235}$ - representado na figura de Alfredo - consolidando a recusa de ambos a aceitar a vida em sociedade e condescendendo ante a solução de viver no exílio.

\section{Estranhamento animal}

A preferência por animais híbridos, exóticos, estrangeiros ou irreais na obra de Murilo Rubião - como, por exemplo, o canguru, o dromedário e o dragão -, que importunam os outros personagens, opõem-se ao meio social onde estão inseridos e mostram-se incapazes de adaptarse às regras e ao decoro da normatividade, faz lembrar o texto de Gilles Deleuze e Félix Guattari a respeito da presença animal dentro da obra de Kafka. Segundo os dois filósofos, o zoomorfismo seria, com efeito, a possibilidade de o homem ultrapassar suas limitações e vencer o automatismo da vida. Os dois filósofos salientam, na obra do escritor checo, a ausência de um bestiário convencional ou de criaturas arquetípicas como o desejo de buscar no animal uma potência - não somente um símbolo - de ressignificação ou de a-significação. $\mathrm{O}$ animal seria, antes de tudo, a capacidade de libertar-se de formas e de atingir apenas intensidades que podem - resgatando os pensamentos de Derrida - ser resvaladas pela arte poética.

Kafka, embora ciente - segundo os filósofos - da impossibilidade da metamorfose plena de um homem num animal dentro dos limites da linguagem e da literatura e do enigma proposto ao se estar sob essa outra pele, usou recorrentemente tal recurso em suas narrativas. Dado que o animal se coloca diante de nós como nosso outro absolutamente inacessível, o autor usa essa transfiguração - ou devir-animal - como possibilidade de desterritorialização do homem. A despeito da incapacidade humana de experimentar plenamente a realidade dos outros animais, Deleuze e Guattari compreendem o devir-animal como a habilidade de vivenciar essas duas

\footnotetext{
${ }^{235}$ Assim como o par homem-animal, a figura do relacionamento fraternal como duplo goza de uma longa tradição dentro da literatura. Há inúmeros exemplos de irmãos - sobretudo gêmeos - que se opõem e, consequentemente, se completam por meio de suas personalidades díspares e, ao mesmo tempo, imprescindíveis uma à outra. A completude de dois irmãos aparece desde a utilização de sósias no teatro cômico clássico até o antagonismo de personalidades em romances como Os irmãos Karamazov, de Fiodor Dostoievski. Como salienta o verbete acerca do duplo do Dicionário de mitos literários, organizado por Pierre Brunel, "a ideia da dualidade da pessoa humana - masculino/feminino, homem/animal, espírito/carne, vida/morte - revela uma crença na metamorfose (até mesmo na metempsicose) que implica uma certa ideia do homem como responsável por seu destino". Além disso, o duplo "é sempre uma figura fascinante para aquele que ele duplica, em virtude do paradoxo que ele representa (ele é ao mesmo tempo interior e exterior, está aqui e lá, é oposto e complementar), e provoca no original reações emocionais extremas (atração/repulsa). De um e de outro lado do desdobramento a relação existe numa tensão dinâmica. O encontro ocorre num momento de vulnerabilidade do eu original". Ver em: BRAVO, Nicole Fernandez. O duplo. In: BRUNEL, Pierre (org.). Dicionário de mitos literários. Trad. SUSSEKIND, Carlos et alii. Rio de Janeiro: José Olympio, 1997, pp. 261-288.
} 
existências ao mesmo tempo. Assim, esse ato possibilita a origem de uma zona heterogênea que não distingue o próprio do homem do próprio do animal nem lhes impõe valores ou sinais:

Devir-animal é, precisamente, transpor um limiar, atingir um continuum de intensidade que só são válidas por elas próprias, encontrar um mundo de intensidade puras, em que todas as formas se desfazem assim como as significações, significantes e significados, em benefício de uma matéria não formada, de fluxos desterritorializados, de signos a-significantes. Os animais de Kafka nunca apontam para uma mitologia nem para arquétipos, mas correspondem apenas a gradientes ultrapassados, a zonas de intensidade livres em que os conteúdos se libertam das respectivas formas, assim com as expressões do significante que as formalizava. Movimentos e vibrações apenas, limiares numa matéria deserta: os animais, ratos, cães, macacos, baratas, diferenciam-se apenas por este ou aquele limiar, por estas ou aquelas vibrações, por um determinado caminho subterrâneo no rizoma ou na toca. ${ }^{236}$

Portanto, o conceito de devir-animal de Deleuze e Guattari opõe-se às considerações de Bataille acerca da metamorfose. A polaridade negativa e positiva, por exemplo, em que a mente e o corpo humanos seriam prisões, limitações e empecilhos que poderiam ser vencidas a partir e por meio da experiência animal dissipa-se e transforma-se em potencialidade singular. $\mathrm{O}$ animal kafkiano, apesar de não possuir a força destrutiva de um lobisomem nem ter a capacidade de destroçar jaulas como os bichos de Bataille, consegue combinar em si mesmo sua própria potência com a do homem.

Deleuze e Guattari concordam, no entanto, com a metamorfose animal enquanto possibilidade de escape e afirmam que o devir-animal nasce como "um mapa de intensidades. É um conjunto de estados, todos diferentes uns dos outros, implantados no homem no momento em que este procura uma saída. É uma linha de fuga criativa que só significa o que ela é”237. O devir-animal define-se como uma "viagem imóvel e no mesmo sítio que só pode ser vivida ou compreendida em intensidade" ${ }^{238}$. Retomando a reflexão de Seligmann-Silva sobre a presença animal em Kafka, percebemos seu alinhamento com o conceito de devir-animal dos dois teóricos franceses, precisamente pela implosão que o escritor checo realiza nas teorias evolucionistas que colocam o homem no topo do mundo animal. Em Kafka, as potências de todas as criaturas terrenas são equivalentes e não há hierarquização de qualquer ordem: “Ao tratar da vida animal, Kafka toca na crise da soberania e da nossa autoimagem. Essas duas crises se lhe aparecem como paralelas. [...] Ele mostra um poder amorfo, teoricamente o monopolizador da violência, que tenta gerir essa vida nua que lhe escapa"239. Entretanto, como

\footnotetext{
${ }^{236}$ DELEUZE, Gilles, GUATTARI, Félix. Kafka: para uma literatura menor. Trad. GODINHO, Rafael. Lisboa: Assírio \& Alvim, 2003, pg. 34.

${ }^{237}$ Idem, ibidem. pg. 69.

${ }^{238}$ Idem. Ibidem.

${ }^{239}$ SELIGMANN-SILVA. Márcio. Op. cit. pg. 152
} 
o próprio crítico acrescenta, o animal e o homem não se posicionam como forças antagônicas, pois "Kafka trabalha com polaridades para desconstruí-las"240.

Algumas considerações dos filósofos também podem ser atribuídas aos animais dentro da prosa muriliana. Ainda que não sejam as criaturas completamente antropomorfizadas das fábulas - onde os bichos não servem senão como revestimento superficial do comportamento e das emoções humanas - Teleco e Alfredo também estão longe de serem animais, tal como reconhecemos na realidade empírica. Sua diferença fundamental para o animal da fábula tradicional vem com a incapacidade do leitor de implicar, a partir da forma escolhida, o caráter do personagem. Seus disfarces excepcionais geram, consequentemente, expectativas no leitor. Teleco, no início da narrativa, usa a forma do coelho - altamente simbólica - para logo destruíla e transformar-se num canguru. Alfredo segue o mesmo caminho e, depois da tentativa de viver como porco, transfigura-se em dromedário. À vista disso, faz-se notar o desejo pela singularidade como propulsor das metamorfoses de ambos os personagens.

Todavia, diferentemente do que acontece em Kafka - como já afirmamos no capítulo anterior - a experiência animal na narrativa muriliana nunca se dá de modo vertical. A metamorfose em bicho, ao contrário do que experimentamos juntos de Gregor Samsa, jamais se aprofunda em suas entranhas, em seu foro mais íntimo, em suas competências e em suas limitações. À linha de fuga animal desenhada pelas metamorfoses nos contos Alfredo e Teleco, $o$ coelhinho falta intensidade, opondo-se ao que Deleuze e Guattari apontam nos animais kafkianos.

Há semelhanças, porém, no deslize que elas proporcionam - seja a partir de seus bestiários inauditos, seja por meio do deslocamento de ponto de vista. Logo, a metamorfose animal em Murilo Rubião, não obstante sua superficialidade, coloca-se como a promessa de novos olhares vis-à-vis a ordem vigorante, de desestabilidade das expectativas lógicas - tal qual fez Alfredo ao conhecer Joaquina - mesmo que a automatização do mundo muriliano consiga sufocar esse ímpeto de renovação. Tais metamorfoses, por seu caráter singular e pela sua ânsia de destruição dos repertórios pré-estabelecidos, dão-se como um processo de estranhamento narrativo, tanto para o leitor quanto para os personagens dos contos.

Retornando aos comentários de Jorge Schwartz acerca de Teleco, o coelhinho, já nos deparamos com alguns comentários concernentes à técnica de estranhamento desenvolvida a partir das metamorfoses do animalzinho. $\mathrm{O}$ crítico destaca, justamente, a necessidade de Teleco em romper com um agrupamento de formas animalescas tradicionais dentro do imaginário

\footnotetext{
${ }^{240}$ Idem, ibidem.
} 
comum da literatura - ou seja, das fábulas, dos mitos e dos contos de fada. Dessa forma, ele pretende alcançar, baseado nessas figuras menos convencionais, sua emancipação e sua identidade própria para livrar-se de sua condição subserviente. Graças às suas metamorfoses ininterruptas e de difícil interpretação, Teleco aguça o instinto de domínio do metódico narrador, levando-o ao desespero. Antes agradáveis e prazenteiras, suas novas formas desestabilizam o cotidiano de seu amigo e dão cabo do relacionamento dos dois:

Vemos como a função inicial das metamorfoses de Teleco é desautomatizar um
repertório convencional através da procura de uma nova forma, que age sobre o
receptor a modo de aguçar a percepção da existência (aquilo que os formalistas russos
denominaram "processo de estranhamento"). As transformações não são poucas:
girafa/ cavalo/ leão/ tigre/ porco-do-mato/ pulga/ bode/ ave desconhecida/ canguru/
perereca/ cachorro/ cutia/ pavão/ lagarto/ rato/ hipopótamo; vaca/ corvo/ burro/ porco/
fera/ andorinha (pelos sons que emite); e finalmente criança. ${ }^{241}$

O mesmo pode ser dito da trajetória de Alfredo, que procura nas metamorfoses - uma vez que ele não consegue se libertar de sua essência humana - ao menos a possibilidade de distanciar-se da convivência social de seus semelhantes. Para isso, nem o ambiente doméstico dos porcos nem a linguagem dos homens conseguiriam satisfazer seu desejo. $\mathrm{O}$ dromedário representa, portanto, a consolidação de um novo ponto de vista diante do senso-comum dominante no povoado, que ainda se organiza ao redor das velhas histórias folclóricas de lobisomens. Aparentemente alheio ao que se passa ao seu redor, Alfredo, contudo - a partir de seu novo olhar humano-animal -, consegue extrair informações inacessíveis aos outros e, com isso, causar deslizes desconfortáveis na ordem aparente das coisas. Além de ser objeto do medo dos habitantes do pequeno vilarejo, ele denuncia, com apenas um comentário, o casamento fracassado de seu irmão com Joaquina.

O percurso da obviedade à singularização determina, à vista disso, as escolhas de Alfredo e de Teleco. Ambos se colocam - ou estão colocados - como personagens à margem da organização social e inaptos a nela se inserirem. Alfredo, por um lado, já cético em relação aos seus próprios dons metamórficos e ciente de sua incapacidade de viver entre os outros homens, tem como opção o isolamento e a paralisia quase estoica da vida de um dromedário. Por outro lado, Teleco anseia parecer-se com os homens e viver entre eles, mas suas tentativas de afirmar sua própria identidade e o reconhecimento dos outros levam-no a um breve período de glória - em suas estripulias como mágico de circo - que logo se evanesce, condenando-o ao desfecho trágico de perder seus encantamentos e morrer totalmente desnudo. Ambos representam, contudo, figuras estranhas dentro de um mundo sistematizado que não lhes oferece lugar tampouco relevância.

${ }^{241}$ SCHWARTZ, Jorge. Op. cit. pp. 50-51. 
Teleco e Alfredo estão sitiados, de certa maneira, no assento que sempre coube aos animais dentro dos ajuntamentos humanos e cuja posição oscila entre o pertencimento e a relegação - ou seja, posição de pouca ou total marginalidade. Entre um ponto e outro dessa linha, situam-se todos os animais. Mais próximo do convívio entre os homens estão, por exemplo, o cachorro, o coelho e o porco, no outro extremo encontram-se o canguru e o dromedário. Retomando as considerações de Dominique Lestel sobre a convivência entre homens e animais e a ideia de animalidade, vemos que esta posição intermediária esclarece, justamente, a razão pela qual eles foram usados como fonte e ponto de vista de pensamentos e reflexões a respeito da humanidade ${ }^{242}$.

De fato, Carlo Ginzburg, ao comentar o processo de estranhamento presente na construção ficcional em diversos momentos históricos, salienta a importância das tentativas de alguns autores em darem um ponto de vista animal aos seus textos. Dessa forma, a partir dessa nova maneira marginal de enxergar o mundo, desse deslize de expectativas e desse distanciamento de perspectiva, o estranhamento mostra-se como um "antídoto eficaz contra o risco a que todos nós estamos expostos: o de banalizar a realidade (inclusive nós mesmos) "243. O exercício de dar voz a um animal - ainda que a linguagem seja humana - e de colocar-se por detrás de seus olhos - também humanos - deve implicar, no entanto, novas interpretações e reflexões a respeito do mundo. Mais uma vez, à diferença do animal fabular, que corresponde às expectativas prévias do leitor em relação à sua personalidade, a dinâmica do estranhamento consolida-se, de fato, na suspensão da trivialidade das fórmulas.

Tanto Schwartz quanto Ginzburg referem-se - quando falam sobre o processo de estranhamento - aos formalistas russos e, mais precisamente, ao texto consagrado a esse assunto de Viktor Chklovski. Nele, o crítico russo aponta a singularização literária como procedimento de tirar a língua e, consequentemente, a realidade de sua inevitável automatização. Para isso, ele usa alguns exemplos da obra de Tolstói que usam, precisamente, o ponto de vista animal como maneira de dar à linguagem novas forças expressivas e, assim, tirá-la do lugar-comum para criar novas imagens: "O objetivo da imagem não é tornar mais próxima da nossa compreensão a significação que ela traz, mas criar uma percepção particular do objeto, criar uma visão e não o seu reconhecimento"244. Ainda segundo Chklovski, ao realizar esse

\footnotetext{
${ }^{242}$ Ver nota de rodapé 185.

${ }^{243}$ GINZBURG, Carlo. Estranhamento: pré-história de um procedimento literário. In: Olhos de madeira: nove reflexões sobre a distância. Trad. BRANDÃO, Eduardo. São Paulo: Companhia das Letras, 2001, pg. 41.

244 CHKLOVSKI, Viktor. A arte como procedimento. In: Teoria da literatura: formalistas russos. Trad. FILIPOUSKI, Ana Maria et alii. Porto Alegre: Editora Globo, 1973, pg. 50.
} 
procedimento, o escritor renova e aumenta a percepção dos objetos e alcança o fim em si mesmo da arte, que possui, por seu lado, o mesmo objetivo da imagem:

E eis que para devolver a sensação da vida, para sentir os objetos, para provar que pedra é pedra, existe o que se chama arte. O objetivo da arte é dar a sensação do objeto como visão e não como reconhecimento; o procedimento da arte é o procedimento da singularização dos objetos e o procedimento que consiste em obscurecer a forma, aumentar a dificuldade e a duração da percepção. $\mathrm{O}$ ato de percepção em arte é um fim em si mesmo e deve ser prolongado; a arte é um meio de experimentar o devir do objeto, o que é já "passado" não importa para a arte. ${ }^{245}$

Tanto Ginzburg quanto Chklovski restringem seus comentários, portanto, ao ponto de vista que o homem idealiza ou imagina como sendo o do animal. Os exemplos que eles usam da obra de Tolstói indicam a presença de pensamentos e visões presumidamente animais sobretudo no conto Kolstomer ${ }^{246}$, em que um cavalo rumina seus rancores e medita sobre a crueldade do homem - como se projetados a partir de uma câmera acoplada na cabeça do animal que traduzisse para a linguagem humana o que nos é, via de regra, inacessível. O discurso, dessa maneira, passa a ser narrado diretamente pelo bicho, apagando, por conseguinte, o autor que se esconde por trás dele e lhe empresta suas palavras.

Por sua vez, ele comporta-se e age como um animal e tão-somente como um animal, sem que a narração de seu ponto de vista influencie numa possível antropomorfização de sua identidade. O processo de estranhamento deslinda-se, portanto, unicamente como instrumento retórico. O mesmo procedimento está presente no conto de Machado de Assis citado anteriormente, assim como no conto também mencionado Um relatório para uma academia, de Franz Kafka, além de outras narrativas curtas do escritor checo, como Josefina, a cantora e Investigações de um cão.

Entretanto nos contos de nosso autor com presença ostensiva de animais, embora também haja deslocamento de percepção devido a tal aparecimento e este não se resuma exclusivamente ao papel de personagem de fábula, há duas diferenças fundamentais em relação ao processo de estranhamento esmiuçado por Chklovski e empregado por Tolstói: eles são potências heterogêneas, nos critérios de Deleuze e Guattari, que misturam e experimentam as capacidades tanto dos animais quanto dos homens e não podem ser definidos nem como uma

\footnotetext{
${ }^{245}$ Idem, ibidem, pg. 45. Grifos do autor.

246 Para exemplificar o processo de estranhamento de que falam Chklovski e Ginzburg, segue uma pequena passagem dos pensamentos do cavalo Kolstomer no conto de Tolstói, em que ele aponta a diferença fundamental entre os homens e os animais: "As pessoas não procuram, em sua vida, fazer o que consideram o bem, e sim a maneira de poder dizer do maior número possível de coisas: é meu. Agora estou persuadido de que nisso reside a diferença essencial entre nós e os homens. Portanto, sem falar de outras prerrogativas nossas, só por este fato podemos dizer, com segurança, que, entre os seres vivos, nos encontramos em nível mais alto do que os homens. A atividade dos homens, pelo menos a dos homens com quem tenho trabalhado, se traduz em palavras, ao passo que a nossa se manifesta em fatos". Ver em: TOLTOI, Leão. Kolstomer. In: Obra completa - volume III. Trad. AMADO, Milton e MENDES, Oscar. Rio de Janeiro: Editora Nova Aguilar, 1993, pg. 892.
} 
coisa nem como outra; e, mais do que o uso das palavras e da linguagem humana, eles podem - e preferem - expressar-se diretamente por meio de metamorfoses ou outras formas de manifestações corporais. Como na maioria dos contos de Murilo Rubião, as metamorfoses de Teleco e Alfredo são narradas ulteriormente pelo narrador-protagonista dos contos. Dessa maneira, apenas algumas falas de ambos são diretamente transmitidas, como, por exemplo, a já citada observação do dromedário sobre Joaquina ou advertência de Teleco acerca de sua instabilidade e seu desejo de transformar-se em animais diferentes para fugir do tédio.

Essas duas diferenças implicam mudanças significativas nos efeitos causados pelos deslizes do estranhamento da narrativa muriliana. Por um lado, se há uma indecisão em relação à identidade dos personagens, não podemos afirmar que o ponto de vista venha de um homem marginalizado ou, de fato, de um animal. A quase ausência de fala tanto de Alfredo quanto de Teleco, por outro lado, tem como resultado a falta de um discurso a que possamos nos fiar e que contemos majoritariamente com as metamorfoses como expressões de sua interioridade. Schwartz nota isso ao ver nas metamorfoses de Teleco a manifestação de seus desejos profundos que ele não consegue exteriorizar de outra maneira, dando origem a um tipo peculiar de estranhamento ${ }^{247}$. Alfredo também tenta usar as palavras, mas logo desiste e opta pela forma do silencioso dromedário.

Outro ponto em comum dos animais dos três contos de Murilo Rubião analisados é que, em todos eles, estamos diante de animais-artistas, ou que experimentaram, em algum momento, faculdades artísticas. O dragão João, devido aos seus problemas com o resto da cidade, oferecese como espetáculo de um circo itinerante e logo junta-se aos saltimbancos da trupe, retornando aos vícios de sua vida pregressa: "Várias e imaginosas versões deram ao seu desaparecimento. Contavam que ele se tomara de amores por uma das trapezistas, especialmente destacada para seduzi-lo; que se iniciara em jogos de jogos e retomara o vício da bebida"248. Teleco tem uma curta e explosiva carreira como mágico, para voltar à casa do amigo e, pouco tempo depois, morrer de maneira degradante. Já Alfredo, embora sem seguir explicitamente a carreira artística, experimenta a palavra, o verbo, para dar um sentido à sua vida. Conhecendo a visão estranhamente metonímica de Alfredo, podemos abarcar no verbo resolver todas as manifestações da linguagem, aí inclusa a literatura. A sagacidade de Alfredo faz que ele enxergue a impotência de suas metamorfoses e de suas possibilidades expressivas, abandonando-as e resignando-se ao exílio. Teleco, por sua vez, insiste nas suas habilidades e, a despeito de todos os esforços, apenas acelera seus passos em direção ao malogro.

\footnotetext{
247 Ver nota de rodapé 241.

${ }^{248}$ RUBIÃO, Murilo. Os dragões. In: Op. cit. pg. 51.
} 
Ao percebermos nesses personagens a figura do artista, inclinamo-nos a concluir que as metamorfoses seriam suas manifestações artísticas e que os animais seriam apenas disfarces. Dessa forma, retornaríamos ao tema da espetacularização da metamorfose. As transformações de Teleco e Alfredo - além das habilidades dos dragões - são, de fato, espetaculares e desempenham tal papel dentro de seus contextos. Elas não são aproveitadas pelos outros senão a partir desse viés. Todos eles, porém, não desejam ser animais - ou artistas - convencionais. Sua luta está, justamente, em romper com a clausura da tradição, parodiando - mesmo que de maneira inconsciente - as lendas dos lobisomens, os animais simbólicos como o coelhinho ou mitológicos como os dragões. No entanto a angústia dos animais-artistas ao buscarem novas figuras que destruam os símbolos consagrados e as formas tradicionais, a partir de um ponto de vista bastante insólito, ganha novos contornos. Temos duas figuras marginalizadas - o animal e o artista - lutando pelo reconhecimento de sua classe e não sabemos, devido à completa fusão entre os dois, de onde realmente partem as metamorfoses. Estamos diante de um animal que busca a forma humana ou de um artista que tenta novos truques? Diante de um homem que vira dromedário ou de um escritor que abandona a impotência da palavra? Todas as opções funcionam e causam estranhamento, tanto no leitor quanto nos outros personagens da narrativa.

Além disso, Teleco e Alfredo usam a metamorfose como meio de expressão preferencial para singularizarem-se e para desautomatizar o mundo. Assim, não há mais o processo descrito por Chklovski em que o artista, seu personagem e, finalmente, seu discurso devem ver e não apenas reconhecer o objeto, a fim de dilatar a percepção que temos dele e criar uma imagem. As metamorfoses nos contos murilianos já são a própria imagem, já são o resultado do processo, ou seja, já são metafóricas. Quando usadas retórica e reiteradamente, portanto, incidem em si mesmas e questionam-se.

Schwartz, acerca da linguagem poética, afirma que "a metáfora se enriquece na medida da força do seu 'estranhamento'. Aquilo que a valoriza é o seu anti-status, ou seja, seu efeito insólito" ${ }^{249}$. Essa parece ser, com efeito, a busca de Alfredo e de Teleco, embora motivada por razões distintas. Ambos desejam ser essa "metáfora enriquecida" de si mesmos que se afasta da previsibilidade dos símbolos e das interpretações fáceis. Também aí se encontra o motivo do desconforto dos alguns personagens - que anseiam em decifrá-los - e da fascinação de outros - que preferem deleitar-se com a beleza das metamorfoses. Todavia, o coelhinho e o dromedário sempre terminam diante de um muro, pois, mais ou menos enriquecidos, eles são sempre uma figura deformada deles próprios. Um animal, como qualquer outra coisa, sempre será alvo de

\footnotetext{
${ }^{249}$ SCHWARTZ, Jorge. Op. cit. pg. 58
} 
taxonomias, classificações, inventários, seriações e sempre se poderá transformar numa figura de linguagem ou de outras maneiras expressivas. Diante da impossibilidade de reinventar-se e de tornar-se uma imagem compatível com seus desejos e capaz de satisfazê-los, os únicos antídotos - se há mesmo um antídoto - encontrados por Alfredo e por Teleco são, respectivamente, a resignação ou o desmantelamento. 


\section{CAPÍTULO IV: Conclusão - A exigência metamórfica}

A poesia é metamorfose, mudança, operação alquímica, e por isso é limítrofe da
magia, da religião e de outras tentativas para transformar o homem e fazer "deste"
ou "daquele" esse "outro" que é ele mesmo.

(Octavio Paz)

Além de serem socialmente deslocados e solitários por natureza, os personagens de Murilo Rubião são, antes de mais nada, desprovidos de passado. Ao tomar a decisão de se transformar em funcionário público, o ex-mágico da Taberna Minhota, por exemplo, só consegue conduzir suas memórias até o momento em que seu corpo irrompeu no palco sobre o qual seus dons se transformariam em lucro, pois - fato ainda mais espantoso que seus truques - ele veio ao mundo sem raízes e sem história. Ali foi seu nascimento, puxando o próprio dono do bar para fora de suas mangas. Teleco, por sua vez, não possui qualquer laço afetivo ou precedente biográfico ele está órfão no mundo e assim continua até o fim de sua vida. Seu amigo também está igualmente solitário, e de suas memórias pregressas sabemos apenas que elas emergem com a presença do mar e que não passam de lembranças ridículas. Do pirotécnico Zacarias, vislumbramos, em seu delírio de morte, apenas algumas imagens desconexas de sua infância, sufocadas e apagadas pela sua condição atual de morto-vivo. O irmão de Alfredo - que se separou deste sem explicação aparente - deixa escapar somente um fragmento de memória constrangido entre os parênteses de um flashback. Como num devaneio, relembra um momento de violência que mais sugere do que explica e que deve ser sufocado a todo custo. Também os dragões pousam na cidadezinha sem identidade e sem história, carregando consigo tão-somente sua vulnerabilidade.

Poderíamos citar mais inúmeros exemplos de como esses personagens estão constantemente à deriva no mundo. Quando se dão conta de que não possuem um passado palpável, eles se lançam de maneira desnorteada ao futuro. Quando, ao contrário, há um passado remoto - afinal, em Murilo Rubião ele é sempre remoto -, o retorno à lembrança idealizada torna-se uma obsessão. Ainda que voltar atrás seja um caminho impossível ou intrincado, como em A noiva da casa azul, Bruma e A cidade, não há outra alternativa senão essa. Se o azimute para o passado, contudo, não (mais) existe, aquele que aponta para o futuro também indica um horizonte virtualmente inalcançável e naufragado de antemão no pessimismo. Os homens e as mulheres lançados no universo muriliano estão encurralados entre um passado e um futuro inexistentes. Toda a experiência e toda a biografia que eles possuem reduzem-se ao próprio 
relato da narrativa - daí uma das razões para a preferência pela primeira pessoa e pelo tempo pretérito.

A primeira e mais óbvia objeção que poderia surgir à relevância da ausência de passado dos personagens murilianos vem do próprio gênero ao qual sua obra se consagrou. De fato, num texto controlado como o conto, em que cada fio de sua trama serve a um efeito específico e que, por isso mesmo, deve ser constantemente aparado, não cabe muito espaço para digressões a respeito do passado dos personagens. Não há um grande choque em lançar criaturas sem antecedentes nas intrigas de um conto. Pelo contrário, a narrativa curta, muitas vezes, deve estabelecer as relações anteriores entre personagens e seus conflitos de maneira indireta, sugestiva ou até mesmo elíptica. Nunca saberemos quais foram as ofensas sofridas por Montresor para que ele planejasse o cruel assassinato de seu amigo e rival Fortunato. O passado conflituoso dos dois pouco interessa à economia da história e é descartado logo no início do conto pelo próprio narrador: "Suportei, da melhor maneira que pude, as muitas injúrias de Fortunato, mas quando ele se atreveu a insultar-me, jurei vingança"250.

Poe se concentra apenas na noite do crime para garantir o efeito surpreendente de $O$ barril de Amontillado ${ }^{251}$ - o escritor norte-americano estava ciente de que o excesso de referências anteriores a esse momento poderia suavizar ou até mesmo anular o choque do desfecho. Por certo, a ausência de esclarecimentos sobre a origem e a evolução do ódio de Montresor, resumido a um desejo intenso por vingança, torna a morte de Fortunato ainda mais hedionda. No entanto, ao esconder os detalhes do relacionamento entre os dois amigos, ou seja, ao deixar de lado o passado que os conduziu até a noite fatídica, Poe não enfraquece os antecedentes para extrair disso apenas o efeito brutal do desfecho. Na verdade, o contista se serve dessa ausência para deixar em aberto as razões de Montresor e, com isso, fortalecer ou atenuar aquele passado de humilhações - cabe ao leitor, consequentemente, preencher as preliminares da narrativa e decidir se condena ou absolve o protagonista.

\footnotetext{
${ }^{250}$ POE, Edgard Allan. O barril de Amontillado. In: Histórias extraordinárias. Trad. PAES, José Paulo. 2. ed. São Paulo: Editora Cultrix, 1958, pg. 93.

${ }^{251}$ Pensamos aqui no peso que o "efeito" tem para a produção de Poe seguindo suas próprias recomendações no ensaio A filosofia da composição: "Eu prefiro começar [uma ficção] com a consideração de um efeito. Mantendo sempre a originalidade em vista, pois é falso a si mesmo quem se arrisca a dispensar uma fonte de interesse tão evidente e tão facilmente alcançável, digo-me, em primeiro lugar: 'Dentre os inúmeros efeitos, ou impressões a que são suscetíveis o coração, a inteligência ou, mais geralmente, a alma, que irei eu, na ocasião atual, escolher?' Tendo escolhido primeiro um assunto novelesco e depois um efeito vivo, considero se seria melhor trabalhar com os incidentes ou com o tom - com os incidentes habituais e o tom especial, ou com o contrário, ou com a especialidade tanto dos incidentes, quanto do tom - depois de procurar em torno de mim (ou melhor, dentro) aquelas combinações de tom e acontecimento que melhor me auxiliem na construção do efeito". Ver em:

A filosofia da composição. In: Poemas e ensaios. Trad. MENDES, Oscar e AMADO, Milton. 3. ed. São Paulo: Globo, 1999, pp. 101-102.
} 
Por que, então, a escassez biográfica das criaturas murilianas incomoda mais do que nos contos de Poe, quando nem mesmo contraria uma das premissas do gênero? Ora, o incômodo nasce justamente da presença contínua e explícita da própria ausência do passado nos contos do escritor mineiro, que, uma vez fixada no horizonte da narrativa, assombra o caminho de seus personagens. Em vez de elipsar a tela de fundo a partir da qual suas histórias são engatilhadas, nosso autor mantém sob vigília um passado - ou uma necessidade de passado - cuja iminência não faria o menor sentido num conto de Poe. Ou seja, o bloco de narrativas de Rubião, aparentemente tão coeso em seu estilo e em seus assuntos, nasce e desenvolve-se a partir de um lapso. Assim, longe de ser um desvio do fio condutor do conto, a urgência por um passado aparece como tema protagonista da obra de Murilo Rubião.

Sob o congelamento temporal que isola cada narrativa muriliana - sempre encalacrada entre ausências -, como ela pode, ao mesmo tempo, ser marcada pelas metamorfoses, um evento cujos desdobramentos se dão precisamente a partir da transição de uma forma a outra no encaixe de um tempo sobre outro? A metamorfose, tradicionalmente, costumou indicar a conexão e a permeabilidade entre as diferentes matérias do mundo. Por sua capacidade metafórica, ela carregou consigo diferentes efígies simbólicas que se sobrepuseram ao rosto humano. À vista disso, seriam as metamorfoses o resultado das tentativas de reconstrução simbólica dessa ausência de experiência passada ou de perspectivas futuras?

No segundo capítulo, por exemplo, vimos a metamorfose como máscara desfigurada de um universo tragicômico, grotescamente hiperbólico e carregado de uma ironia amarga. Já no terceiro capítulo, notamos a ambiguidade das relações entre homens e animais e seus decorrentes estranhamentos, inclusive no desvio das interpretações simbólicas tradicionais. No entanto, mais do que buscar um sentido nessas metamorfoses, observamos como elas se desenvolvem no texto e os efeitos formais por elas desencadeados.

Como consequência e conclusão dessas reflexões, neste capítulo buscaremos desenvolver um exercício mais interpretativo a propósito das metamorfoses, tendo em vista todas as discussões anteriores sobres os laços que ligam esse tema ao plano formal dos contos de Rubião, auxílios imprescindíveis para tal análise. Dessa forma, a partir das aventuras dos personagens murilianos, traçaremos algumas semelhanças e diferenças entre os aspectos mais marcantes das metamorfoses que aparecem nos contos. Relacionaremos, assim, a própria trajetória errante desses heróis sem passado e sem futuro com os caminhos trilhados pelas metamorfoses ao longo das narrativas, uma vez que elas também indicam a busca desses sujeitos por uma metaforização de suas experiências. Como já afirmamos reiteradamente ao longo dos capítulos anteriores, a metamorfose no conto de Murilo Rubião parece se equilibrar 
de maneira constante entre a mecanicidade do artifício e o vislumbre da totalidade simbólica. Será, portanto, essa corda-bamba que conduzirá as discussões desenvolvidas nesta seção, sem que percamos de vista uma consequente chave interpretativa do universo ficcional de Rubião a partir, justamente, do nosso tema.

\section{A demanda da metamorfose}

Vimos, no terceiro capítulo, que as diferentes metamorfoses animais encontradas tanto em Teleco, o coelhinho como em Alfredo parecem estar na metade do caminho que separa o simples disfarce da potência figurativa. Se, por um lado, alguns bichos servem apenas como um dispositivo para o avanço da narrativa, cuja enumeração hiperbólica contribui para o efeito tragicômico da história, por outro lado, alguns animais ganham força figurativa e densidade interpretativa. Esse é o caso, por exemplo, do dromedário, do coelho e do canguru. Tal interpretação simbólica ou metafórica da presença animal, de tão arcaica e costumeira, parece ser inevitável à leitura. Ela nasce sobretudo quando mesclada com características humanas, quando a antropomorfização esbarra no campo das fábulas. Mesmo diante da presença exótica de figuras ausentes em qualquer dicionário de símbolos - como no caso do canguru e do dromedário -, as características marcantes desses animais não deixam de nos conduzir a certas interpretações sobre os personagens metamorfoseados. Alfredo enfatiza seu estoicismo ao se isolar sob a figura de um dromedário, já Teleco/Barbosa acentua sua violência e sua irascibilidade sob a figura ereta, forte e viril de um canguru.

Segundo Benedito Nunes, a presença animal na literatura sempre carrega um sentido de fundo que torna inevitável uma interpretação primeira, seja qual for a espécie escolhida. Devido à sua existência emblemática e ao mesmo tempo marginal dentro do mundo dos homens, os animais, para Nunes, conciliam em si a distância do outro e a simbolização do duplo. O fator antropomórfico que move esse pêndulo indica, por sua vez, o grau de figuração do personagemanimal; quanto mais próximo da imagem e do comportamento humanos, mais metafórico ele será. Como consequência, o animal tem sua condição alterada ao status de quase-humano. Embora não passe desse reflexo distorcido do homem visto a partir de si mesmo, a vestimenta animal consegue, em virtude dessa deformação, representar as características humanas mais extremas. Ainda segundo Nunes, isso explica o uso do animal como símbolo do baixo:

Com o animal, as relações são, sobretudo, transversais, ou seja, o animal é considerado o oposto do homem mas ao mesmo tempo uma espécie de simbolização do próprio homem. Na acepção comum, simboliza o que o homem teria de mais baixo, de mais instintivo, de mais rústico ou rude na sua existência. Por isso mesmo o animal para 
nós é o grande outro da nossa cultura, e essa relação é muito interessante como tópico de reflexão. ${ }^{252}$

De maneira geral, seja como o duplo, seja como o outro do homem, a presença animal em Murilo Rubião obedece a essas duas vertentes. Há, na mesma medida, uma força que busca na metamorfose animal a conformidade com seu meio - como no itinerário trágico de Teleco assim como há, por meio do mesmo tipo de metamorfose, a procura pela alteridade e pela marginalidade animal, tal qual percebemos no retiro de Alfredo. Os dois heróis murilianos vislumbram no animal possibilidades totalmente opostas - o primeiro busca a inserção e o segundo a exclusão. Ambos, no entanto, se frustram com o resultado intermediário de suas tentativas. Mais uma vez, retornamos aos conceitos de ajuste/desajuste de Jorge Schwartz ${ }^{253}$. Assim como as tentativas constantes de ajuste, por parte de Teleco, levam-no à destruição, a recusa de uma existência socialmente compartilhada conduz Alfredo à esterilidade do mutismo.

Entre o desejo e a ruína, contudo, há o meio-termo da narrativa. Nesse espaço-tempo que deve conduzir o fio da trama desde o início até o desfecho do conto, resta pouco conteúdo que não esteja ligado intimamente a essa dinâmica do reajuste. Com efeito, a história não avança senão quando acompanha o passo da multiplicação das metamorfoses. Todavia, o avanço para o desfecho, retomando as reflexões de Arrigucci Jr., mostra-se igualmente intrincado por essa multiplicação que desemboca em mais multiplicações.

As metamorfoses, portanto, surgem como um dispositivo narrativo que tem um fim em si mesmo e que se repete hiperbolicamente. Ainda segundo o crítico, tal procedimento, em alguns contos, chega a alcançar o extremo da confusão entre o que é metamorfose e o que é narrativa, uma vez que aquela se sobrepõe a esta e se transforma numa cobertura alegórica do próprio desenvolvimento do texto ficcional. Como exemplo de fusão entre tema e procedimento, Arrigucci Jr. destaca o conto $O$ edifício, no qual “a construção infindável de um 'absurdo arranha-céu', a que sempre é possível acrescentar novos blocos, pode ser entendida também como uma alegoria da própria construção ficcional que se está lendo"254.

No primeiro capítulo, a possibilidade de uma leitura metalinguística das metamorfoses já havia sido traçada por meio da análise do cortejo de Marina, a intangível. Nele, a confusão excessivamente ornamentada de um desfile musical, com ares de devaneios líricos, resulta nos

\footnotetext{
252 NUNES, Benedito. O animal e o primitivo: os Outros de nossa cultura. Apresentação de Jaime Larry Benchimol. História, Ciências, Saúde - Manguinhos, Rio de Janeiro, v.14, suplemento, pg. 282, dez. 2007. ${ }^{253}$ Ver SCHWARTZ, Jorge. Murilo Rubião: a poética do uroboro. Op. cit. pp. 39-41.

${ }^{254}$ ARRIGUCCI JR, Davi. O mágico desencantado ou as metamorfoses de Murilo. Suplemento, Belo Horizonte, n. ju 2016, p. 13-15, 2016.
} 
temidos e frustrantes poemas que o narrador desejava compor. A figura do artista também esteve presente nas reflexões sobre o Ex-mágico da Taberna Minhota e O pirotécnico Zacarias, no segundo capítulo, e na sua comunhão íntima com a marginalidade animal, no terceiro capítulo. A partir dessas leituras, percebe-se uma relação nítida entre certa ambição criativa, cuja finalidade primordial permanece velada, e as metamorfoses de todos esses contos. Em algumas histórias, castiga-se o desejo pelo novo ainda em seu estado germinal - quer na releitura grotesca do pecado original, em Aglaia, quer na curiosidade voyeurística pelo vizinho recém-chegado, em $O$ homem do boné cinzento. À vista disso, o aniquilamento de qualquer aspiração à novidade apresenta-se como o requisito básico de sobrevivência dentro do universo muriliano. Alfredo e o ex-mágico aprenderam a lição e, cada um à sua maneira, distanciaramse do convívio dos homens e abdicaram de suas metamorfoses. Já Teleco e os outros aprenderam na pele qual é o resultado da insistência - a autodestruição.

Bárbara, um dos personagens mais hiperbólicos da ficção muriliana, representa de maneira exponencial essa voracidade nunca saciada por novos objetos. Sua exigência reiterada pelo novo, sempre atendida por seu marido, resulta na deformação do seu corpo até os limites do grotesco. Nenhum pedido concedido, porém, é capaz de satisfazê-la. Dessa forma, conforme seu marido - e narrador do conto - corre atrás da realização de seus desejos, Bárbara vai ganhando dimensões pantagruélicas a cada presente recebido. O narrador, agarrado a um passado idealizado quando os dois eram crianças e se apaixonaram, obedece às ordens de sua mulher com a mesma "natural inconsequência da infância"255. No entanto, tudo isso já vinha anunciado nos primeiros parágrafos do conto, no momento em que o narrador resume a sua situação conjugal e introduz o conflito que vai guiar seu relato:

\begin{abstract}
Bárbara gostava somente de pedir. Pedia e engordava.
Por mais absurdo que pareça, encontrava-me sempre disposto a lhe satisfazer os caprichos. Em troca de tão constante dedicação, dela recebi frouxa ternura e pedidos que se renovam continuamente. Não os retive todos na memória, preocupado em acompanhar o crescimento do seu corpo, se avolumando à medida que se ampliava sua ambição. Se ao menos ela desviasse para mim parte do carinho dispensado às coisas que eu lhe dava, ou não engordasse tanto, pouco me teriam importado os sacrifícios que fiz para lhe contentar a mórbida mania. ${ }^{256}$
\end{abstract}

De resto, a narrativa, assim como Bárbara, não visa senão a engordar a situação inicial com os inusitados pedidos e com o aumento do corpo da heroína. Voltamos, portanto, às considerações de Arrigucci Jr. sobre o entrelaçamento que une a metamorfose à construção narrativa $^{257}$. A ausência de futuro como um objetivo para tais transformações e a obsessão do

\footnotetext{
${ }^{255}$ RUBIÃO, Murilo. Bárbara. In: Murilo Rubião - obra completa. Op. cit. pg. 27.

256 Idem, ibidem.

257 Ver nota de rodapé 254.
} 
narrador por seu passado idealizado ${ }^{258}$ faz a história estacionar na passividade deste e na ambição desmedida de Bárbara. Nem o nascimento de um filho, "um ser raquítico e feio, pesando um quilo" 259 , mostra-se capaz de romper com essa dinâmica. Com efeito, seu aparecimento na história só fortalece o efeito grotesco do conto. Lado a lado, mãe e filho garantem um contraste estético que põe ainda mais em evidência a monstruosidade da situação.

Os pedidos, contudo, continuam à revelia da insatisfação do narrador. Embora ameace desobedecer sua esposa, ele não consegue dar fim aos caprichos de Bárbara e sempre cede às suas invencionices. Dessa maneira, a intriga do conto avança e, paradoxalmente, paralisa devido a dois eixos de ação que se alimentam, mas que também colidem um contra o outro. Por um lado, temos a ambição desconhecida e jamais explicada de Bárbara, por outro lado, observamos a submissão - e a revolta sufocada - de seu marido/narrador.

Para Ricardo Iannace, a narrativa de Rubião, grosso modo, tem como força motriz esse choque gerado pela ambição metamórfica, sua ineficácia e a incompreensão das testemunhas e das vítimas de tais eventos. O crítico afirma que esse jogo de ação e reação está no cerne da criação muriliana, pois "a reincidência exaustiva do múltiplo e do interminável engrena esse dínamo que é o fantástico, tal qual é concebido pelo autor de $O E x$-mágico"260. A única maneira de interromper esse ciclo, já comentada brevemente, está em abandonar-se à não-criação. Ou seja, ela consolida-se na recusa de Alfredo e do ex-mágico, por exemplo, de compartilhar seus dotes sobrenaturais.

No entanto, ao abandonar a metamorfose de seus corpos e do espaço ao redor, a ação da narrativa também cessa e dirige-se ao silêncio, seja por meio da peregrinação de Alfredo, seja a partir do confinamento do ex-mágico. Essa também é a impressão deixada pelo desfecho de Bárbara. Se a ambição da protagonista se expressa metaforizada por seus desejos, cada um à sua maneira, inusitados e simbólicos (o oceano, um baobá e um navio), o derradeiro pedido dá margem ao alívio de uma resolução. Em vez de suplicar pela lua, como temia o narrador ao ver sua esposa contemplando o céu, Bárbara pede "uma minúscula estrela, quase invisível ao seu lado"261. A última frase do conto, que em outro contexto seria interpretada como um recomeço

\footnotetext{
${ }^{258}$ Há uma passagem no conto que resume essa obsessão do narrador com sua vida pregressa junto de Bárbara. Após ganhar um baobá do marido, a heroína de Rubião passa a se comportar como uma adolescente. Suas atitudes, consequentemente, despertam a comoção do narrador: "Feliz e saltitante, lembrando uma colegial, Bárbara passava as horas passeando sobre o grosso tronco. Nele também desenhava figuras, escrevia nomes. Encontrei o meu debaixo de um coração, o que muito comoveu. Esse foi, no entanto, o único gesto de carinho que dela recebi. Alheia à gratidão com que eu recebera a sua lembrança, assistiu ao murchar das folhas e, ao ver seco o baobá, desinteressou-se dele. Ver em: RUBIÃO, Murilo. Bárbara. In: Murilo Rubião - obra completa. Op. cit. pg. 30. ${ }^{259}$ Idem, ibidem. pg. 29.

${ }^{260}$ IANNACE, Ricardo. Murilo Rubião e as arquiteturas do fantástico. São Paulo: Editora da Universidade de São Paulo/Fapesp, 2016, pg. 142. Grifos do autor.

261 RUBIÃO, Murilo. Bárbara. In: Murilo Rubião-obra completa. Op. cit. pg. 32.
} 
do ciclo desejo/exigência/obediência, ora parece indicar o desenlace do conflito do casal. Um conciso "fui buscá-la"262 apazigua os desdobramentos metamórficos e neutraliza sua dinâmica. A pequena estrela surge como metáfora da aquietação de Bárbara, conformada à ineficiência de suas demandas hiperbólicas. O relato pode, portanto, cair no silêncio.

Nisso, a trajetória de Bárbara se assemelha à de Teleco. Ambos constituem um polo de atração para o qual são lançados todos os elementos desenvolvidos pelos contos, que não arrefecem senão com a morte de suas ambições. Tanto um quanto outro ditam o tempo da narrativa, que flui ou que paralisa em repetições segundo seus caprichos. A potência do funcionamento dessas máquinas de desejo dá ao relato no passado, compartilhado pelos narradores testemunhas, a veemência do presente. Apesar de os eventos narrados já estarem acomodados e organizados - fato colocado em evidência na linguagem austera da narração -, não há conciliação entre os dois planos temporais da história. A incompreensão do presente reacende os eventos do passado e o percurso dos protagonistas-título prescindem de seus desfechos. Os narradores, por sua vez, vivem os acontecimentos outrora observados num estado de "presente perpétuo"263, de estupor contínuo, pois não há nada em suas realidades além de Bárbara e Teleco.

Entretanto, a rememoração de um passado que continua a ocupar todo o presente, mas que permanece substancialmente absurdo e misterioso, ativa a ironia cega que descrevemos no segundo capítulo. A ausência de experiência crítica do narrador-testemunha em nada difere da destruição dos corpos metamórficos por ele observados, tamanha a proximidade entre as duas instâncias.

Teleco e Bárbara estão igualmente suscetíveis a um desejo que busca sua realização última e total. Nem eles, nem os narradores, contudo, se mostram aptos a desvelar quais são suas razões primordiais e quais são os objetivos de suas ambições. Colocados num plano

\footnotetext{
262 Idem, ibidem.

263 A expressão foi emprestada de Tzvetan Todorov, encontrada num texto em que o crítico analisa o círculo literário da Demanda do Santo Graal, durante a Idade Média europeia. Nessa passagem, ele comenta a lógica narrativa que articula os inúmeros textos que fazem parte do universo da Távola Redonda: “A lógica narrativa implica, idealmente, uma temporalidade que se poderia qualificar como sendo a do 'presente perpétuo'. O tempo é aqui constituído pelo encadeamento de inúmeras instâncias do discurso; ora, estas definem a própria ideia do presente. Fala-se a todo instante do acontecimento que se produz durante o próprio ato de falar; existe um paralelismo perfeito entre a série dos acontecimentos de que se fala e a série das instâncias do discurso. O discurso nunca está atrasado, nunca adiantado com relação ao que evoca. A todo instante também, as personagens vivem no presente, e somente no presente; a sucessão dos acontecimentos é regida por uma lógica própria, não é influenciada por nenhum fator externo". Se, na demanda do Santo Graal, porém, o tempo da narrativa é a sobreposição do tempo da ação e do tempo da fala - o que dá origem a um texto miticamente atemporal -, a preferência pelo passado, em Murilo Rubião, resulta no efeito irônico descrito acima. Ver em: TODOROV, Tzvetan. A demanda da narrativa. In: As estruturas narrativas. Op. cit. pg. 180.
} 
platônico ${ }^{264}$, o estopim e a finalidade da demanda metamórfica - metaforizados, num caso, pelas roupagens animais, no outro, pelos objetos que engordam e distorcem o corpo permanecem ocultos de todos. Assim, o leitor se depara com imagens potencialmente metafóricas, em alguns casos de aparente profundidade simbólica, que rodopiam por cima de uma situação indecifrável cuja incapacidade de se desdobrar em novas intrigas resulta na reincidência da mesma ação por infinitas vezes.

Se na metamorfose há uma condição apriorística de transformação do espaço-tempo do mundo (neste caso, de um texto), o conto de Murilo Rubião quebra esse pressuposto e dá origem ao paradoxo da narrativa que caminha e se transfigura sem sair do mesmo lugar, do mesmo momento e da mesma intriga. Daí, mais uma vez, sua semelhança com o texto dramático ambos repisam as mesmas três unidades. Como já observamos anteriormente, há uma movimentação mecânica e artificial no palco muriliano que enrijece os corpos de seus atores e que os transforma em personagens tragicômicos de uma farsa repetitiva e grotesca. Na medida em que o conflito inicial ganha contornos cada vez mais hiperbólicos, a atmosfera de teatro de vaudeville, ornamentado por trajes da commedia dell 'arte, acentua-se e dá vida a um espetáculo ofuscante. Suas enormes proporções, porém, maquinizam os atos e paralisam os gestos e as feições, que caem na mesmice da autodestruição. Quanto mais Teleco e Bárbara enriquecem suas performances com novos desejos e novas fantasias (na ambivalência do termo), maior é a insuficiência de suas ações - e transfigurações.

Esse impasse da transformação aprisionada origina os dois movimentos metamórficos que, desde o início deste estudo, foram apresentados, sugeridos e delineados ao longo de todos os capítulos - a metamorfose-símbolo e a metamorfose-artifício. Por um lado, a hipérbole metamórfica das histórias de Rubião deixa ao leitor a impressão de um texto que, em todo seu conjunto, parece conotar e simbolizar o mesmo signo de inúmeras maneiras. Compacto e centralizado, o conto muriliano possui um centro gravitacional que sustenta, ao redor de si, manifestações de uma mesma irradiação originada e disseminada por esse núcleo. Entretanto,

\footnotetext{
${ }^{264}$ Há, de fato, muita semelhança entre Bárbara e Teleco e as discussões sobre o desejo e o amor apresentadas n' $O$ banquete de Platão, cujo pano de fundo são, justamente, as conversas sobre a medida e a desmedida dos convivas em relação ao consumo de bebidas e comidas num festim. A busca por aquilo que falta, a essência desse sentimento e a demanda por mudança e por completude são alguns problemas arrolados na fala de Sócrates ao longo do diálogo, sobretudo quando refletem as ideias de Diotima sobre o tema: "E de fato corre um dito, continuou ela, segundo o qual são os que procuram a sua própria metade os que amam; o que eu digo porém é que não é nem da metade o amor, nem do todo; pelo menos, meu amigo, se não se encontra este em bom estado, pois até os seus próprios pés e mãos querem os homens cortar, se lhes parece que o que é seu está ruim. Não é com efeito o que é seu, penso, que cada um estima, a não ser que se chame o bem de próprio e de seu, e o mal de alheio; pois nada mais há que amem os homens senão o bem; ou te parece que amam? ". Ver em: PLATÃO. O banquete. In: Diálogos. Trad. SOUZA, José Cavalcante; PALEIKAT, Jorge; COSTA, João Cruz. São Paulo: Abril Cultural, 1983, pg. 37.
} 
o ponto-médio de suas tramas fantásticas, de onde deve vir sua motivação primordial - a primeira faísca da história -, mantém-se incógnito e sequer é insinuado. Dessa forma, há uma sucessão de imagens metamorfoseadas que, embora nos insufle à busca por significados, deixam a impressão de um invólucro interiormente oco.

\section{A revolta da metamorfose}

Com efeito, ambos os contos, assim como os outros analisados ao longo deste estudo, já apresentam tramas prefiguradas e delimitadas logo em seus primeiros parágrafos. Os desejos por mudança a partir de um viés extraordinário (representados pelo crescimento de Bárbara e pelas metamorfoses de Teleco) e de fuga do insólito (tal qual observada nas tentativas do exmágico e de Zacarias) já são anunciados desde o início do relato do narrador. Esse primeiro impulso dos personagens em busca da resolução de seus conflitos está condensado e mascarado no núcleo dos contos.

Para além disso, não há senão a repetição exaustiva desse primeiro estímulo. Em suma, à semelhança das histórias mais antigas e tradicionais ${ }^{265}$, o conto muriliano avança como num jogo de espelhos dos circos (ambiente, aliás, muito caro ao autor) - a mesma imagem do início reflete-se infindamente, alterando somente a face apresentada em cada uma das superfícies. Vistas através de lentes mais amplas, quase todas as situações narrativas da obra de Murilo Rubião podem ser encontradas no meio dessa sala de espelhos, cujo reflexos entregam apenas variações deformadas e grotescas desse centro.

Assim seguem as histórias de Rubião, movidas por ações encadeadas que recusam pormenores descritivos ou profundidades psicológicas. No entanto, em vez de construir um argumento que consolide uma situação fantástica e que permita o desenrolar das ações dos

\footnotetext{
265 Além do ciclo da Demanda do Graal (ver nota de rodapé 263), há outras narrativas cujo andamento se dá especificamente por meio de ações encadeadas a uma ação primeira, que, por sua vez, continua a reverberar naquelas. Essa é a estrutura, por exemplo, das Mil e uma noites. Mamede Mustafa Jarouche explica que, a partir de um prólogo-moldura, ou seja, a "história das histórias", desenrolam-se inúmeras narrativas que, em sua essência, repisam e dão continuidade ao mesmo argumento daquela. Tendo como base esse rígido padrão, podemse contar as "histórias exemplares" da sabedoria popular: "A existência e a valorização da história exemplar pressupõe, como parece óbvio, um mundo em que a experiência é pensada como algo que se comunica e cuja possibilidade de transmissão é dada pela repetição: são estruturas semelhantes que se reproduzem incessantemente, sem que no entanto possam ser reduzidas, em seu funcionamento no interior de determinado quadro narrativo mais amplo, a um processo previsível e automático, visto que a própria dinâmica interna da narrativa determina o resultado das sucessivas histórias exemplares que vão se sucedendo". Ver em: JAROUCHE, Mamede Mustafa. Uma poética em ruínas. In: Livro das mil e uma noites: volume I: ramo sírio. Trad. JAROUCHE, Mamede Mustafa. 4. ed. São Paulo: Biblioteca Azul, 2017, pg. 24.
} 
personagens dentro de seus limites - como acontece no romance de aventuras ${ }^{266}$ e nos contos da literatura fantástica tradicional -, a narrativa de nosso autor coloca a ação como espelho do próprio elemento insólito inicial. Não há, portanto, o desdobramento típico das histórias de ação, como nos romances policiais e de mistério (enigma-peripécias-elucidação). Há, pelo contrário, a quase ausência de desdobramento de novos conflitos ao longo da trama - o enredo enxuto dos contos de Murilo Rubião pode ser resumido em poucas palavras. Dessa maneira, retornamos mais uma vez à repetição hiperbólica que caracteriza a metamorfose-artifício. A despeito do avanço da narrativa, as situações encadeadas a partir do contratempo inicial não se emancipam de seu centro e, retomando a sala dos espelhos, enfileiram-se como ilusões (afinal, estamos no universo dos artistas, dos mágicos e dos pirotécnicos) que, de tão ostensivas, nos levam a duvidar de que exista, de fato, algo em sua retaguarda.

A sequência de ações condutora do fio narrativo dos contos possui, porém, a qualidade fundamental de ser movida por metamorfoses. Com efeito, a metamorfose, em sua essência, não se deixa ser tomada apenas por um dinamizador insólito ordinário (adjetivos contraditórios somente em aparência). Ou seja, a metamorfose não se permite ser vista como um recurso vezeiro do gênero fantástico. Ela carrega consigo, à sua revelia, a potência de metaforizar a realidade. Desde o surgimento das primeiras histórias carregadas de metamorfoses - como nos mitos, nas lendas e nos contos de fada -, a passagem de uma matéria a outra esteve marcada pelo viés da semelhança e deu origem às figuras de linguagem da retórica textual ${ }^{267}$.

Originadas por uma experiência coletiva, essas histórias mostravam os fios condutores que ligavam elementos aparentemente tão díspares naquilo que eles possuíam em comum. Tais semelhanças, uma vez estabelecidas, transcendiam sua existência ao rés-do-chão e se alçavam a outros planos de significação. Isto é, elas adquiriam a potencialidade de uma forma simbólica, de uma força expressiva que antecede seu uso e seu sentido ${ }^{268}$. Por consequência, o mundo das

\footnotetext{
${ }^{266}$ A ação muriliana parece muito diferente, de fato, daquela desenvolvida por Adolfo Bioy Casares n'A invenção de Morel e descrita por Jorge Luis Borges. Assumidamente artificial e sem qualquer compromisso com a verossimilhança, a novela de Bioy Casares, segundo Borges, constrói um forte argumento para que, a partir dele, se desenrole a sequência de eventos insólitos da ilha desconhecida. Essa premissa robusta permite, ainda segundo Borges, a livre circulação das intrigas e das peripécias que se abatem sobre os personagens, sem que o mesmo argumento seja repisado em cada acontecimento narrado, tão-somente com uma nova roupagem: "O romance de aventuras, ao contrário [do romance realista e do romance 'psicológico'], não se apresenta como uma transcrição da realidade: é um objeto artificial que não comporta nenhuma parte injustificada. $\mathrm{O}$ temor de incorrer na mera variedade sucessiva de $O$ asno de ouro, das sete viagens de Simbad ou de D. Quixote impõe-lhe um rigoroso argumento". Por certo, o conto de Murilo Rubião está muito mais próximo da " mera variedade sucessiva" do que da intrincada aventura do protagonista d'A invenção de Morel. Ver em: BORGES, Jorge Luis. Prólogo. In: CASARES, Adolfo Bioy. A invenção de Morel. Trad. MOLINA, Sérgio. 4. ed. São Paulo: Biblioteca Azul, 2016, pg. 8 .

${ }^{267}$ Ver a introdução deste estudo.

${ }^{268}$ Neste parágrafo, seguimos de perto as considerações de Michel Foucault sobre o tema da semelhança e de sua representação cotidiana, mística e artística. Segundo o filósofo francês, a representação artística deste momento
} 
semelhanças, responsável pelo engendramento das metamorfoses simbólicas, implica necessariamente um passado.

A busca pela imagem que represente, com exatidão e de maneira íntegra, esse impulso inicial que motiva os personagens murilianos - ou seja, a imagem derradeira - está, portanto, na origem da impressão causada pela metamorfose-símbolo. Antes de ser uma concretização, essa transformação implica uma necessidade. O desejo pela forma final (Teleco, Alfredo), pela satisfação total de sua ambição (Bárbara) ou pelo estabelecimento de uma nova aliança com o mundo (a vontade de ter o poder de criar "um arco-íris que cobrisse a Terra de um extremo ao outro" 269 expressada pelo ex-mágico) está ligado à força do símbolo. Essa dimensão primitiva do pensamento, que, em menor escala, ainda conecta os homens ao mundo e determina suas experiências, parece surgir igualmente como uma exigência para todos esses personagens do universo muriliano e, consequentemente, para sua própria narrativa - a exigência por profundidade.

Como aponta Barthes, o símbolo prevê, dentro de seus limites, uma consciência comum que liga e sobrepõe o elemento simbólico a uma experiência, a um valor ou a uma prática comunitária. Devido a esse movimento de justaposição, o símbolo concentra e dispersa uma força interior que, dada a sua potência de irradiação, por vezes ultrapassa a importância de seu próprio conteúdo:

\begin{abstract}
A consciência simbólica vê o signo em sua dimensão profunda, poder-se-ia quase dizer: geológica, já que a seus olhos é a superposição do significado e do significante que constitui o símbolo; existe a consciência de uma espécie de relação vertical entre a cruz e o cristianismo: o cristianismo está sob a cruz, como uma massa profunda de crenças, de valores e de práticas mais ou menos disciplinadas ao nível de sua forma. A verticalidade da relação traz duas consequências: por um lado, a relação vertical tende a parecer solitária: o símbolo parece manter-se de pé no mundo, e mesmo quando se afirma que ele abunda, é sob a forma de uma "floresta", isto é, de uma justaposição anárquica de relações profundas que não se comunicariam, por assim dizer, senão por suas raízes (os significados); e, por outro lado, essa relação vertical aparece forçosamente como uma relação analógica: a forma se parece (mais ou menos, mas sempre um pouco) com o conteúdo, como se ela fosse em suma produzida por ele, de modo que a consciência simbólica recobre talvez por vezes um
\end{abstract}

funciona como um espelho cristalino em face do mundo. Como as correspondências já estão dadas, basta ao artista dar forma, por meio de repetições, àquilo que os homens já veem diante de si: "Até o fim do século XVI, a semelhança desempenhou um papel construtor no saber da cultura ocidental. Foi ela que, em grande parte, conduziu a exegese e a interpretação dos textos: foi ela que organizou o jogo dos símbolos, permitiu o conhecimento das coisas visíveis e invisíveis, guiou a arte para representa-las. O mundo enrolava-se sobre si mesmo: a terra repetindo o céu, os rostos mirando-se nas estrelas e a erva envolvendo nas suas hastes os segredos que serviam ao homem. A pintura imitava o espaço. E a representação - fosse ela festa ou saber - se dava como repetição: teatro da vida ou espelho do mundo, tal era o título de toda linguagem, sua maneira de anunciar-se e de formular seu direito de falar". Ver em: FOUCAULT, Michel. As palavras e as coisas. Trad. MUCHAIL, Salma Tannus. 4. ed. São Paulo: Martins Fontes, 1987, pg. 33.

${ }^{269}$ RUBIÃ̃, Murilo. O ex-mágico da Taberna Minhota. In: Murilo Rubião - obra completa. Op. cit. pg. 26. 
determinismo mal liquidado: existe pois o privilégio maciço da semelhança (mesmo quando se sublinha o caráter inadequado do signo). ${ }^{270}$

Há, portanto, segundo Barthes, duas consequências originadas pela verticalidade simbólica: a relação quase autônoma entre o símbolo já cristalizado e suas "raízes significados" e, de maneira analógica, entre o conteúdo e a representação simbólica, cujo domínio se acomoda no mundo das semelhanças. Todavia, o próprio crítico já adianta o caráter mal-ajambrado que pode surgir desse segundo movimento, que em sua ânsia por totalidade recobre inadequadamente o signo representado. Com efeito, ambos os movimentos não se concretizam positivamente na obra de Murilo Rubião. Apenas o segundo deles encontra-se em sua obra, mas em seu aspecto mais negativo - $\mathrm{o}$ da inadequação.

À primeira consequência da verticalidade do símbolo, contrapõe-se uma realidade sem passado e, por conseguinte, sem futuro, em que não há a possibilidade de erguer um símbolo abundante e compartilhável (fato reconhecido, mais de uma vez, pelo ex-mágico). Estamos diante de um mundo habitado por homens e mulheres sem qualidades e sem conhecimentos ${ }^{271}$, cujas ações irrefletidas logo se refletem em prescindíveis metamorfoses que nunca alcançam o objetivo de seus desejos. Afinal, há algum desejo que as move? Falta-lhes, para isso, a profundidade de uma consciência enraizada no solo comum da "floresta simbólica", que os colocassem de pé mesmo que solitários.

As epígrafes bíblicas, presentes em todos os contos (ressaltamos a peculiaridade de Memórias do contabilista Pedro Inácio, cuja epígrafe dupla vem da Bíblia e das Memórias póstumas de Brás Cubas), fixam no horizonte dos contos a possibilidade de um terreno partilhado, universal e comunitário - elas indicam a potência de um passado. Surge, também, com elas, a expectativa de que os contos de Rubião sejam ecos do livro primeiro, das primeiras

\footnotetext{
${ }^{270}$ BARTHES, Roland. A imaginação do signo. In: Crítica e verdade. Trad. PERRONE-MOISÉS, Leyla. 3. ed. São Paulo: Perspectiva, 2009, pg. 43. Grifos do autor.

${ }^{271}$ Ou melhor, homens e mulheres que não possuem senão uma qualidade, que, por sua vez, está ligada diretamente à aproximação ou ao distanciamento que eles perpetuam em relação às metamorfoses. No entanto, mesmo esses personagens tão tipificados, ou seja, tão próximos a uma representação meramente simbólica das personalidades humanas, também extravasam sua própria condição atávica e, por vezes, confundem a leitura de seus caracteres que nos parecia, a priori, automática. Eziel Belaparte Percino descreve o aspecto de deslizamento simbólico da obra muriliana em relação aos seus personagens: "Há em Rubião este habilíssimo modo de conferir extracompetência. Em geral, ele estiliza e recategoriza tipos, adaptando-os, esvaziando-os num fortíssimo mundo fantasista, como mistura monstruosa, conjugando seres para formar extra-seres, impedindo que se fixem simplesmente como 'pessoas'. Sua fiç̧ão é, assim, dupla: personagens como tipos humanos (pirotécnicos, jornalistas, funcionários públicos), mas que, ao mesmo tempo, não se encerram nos tipos humanos [...]. A crítica que não sai dos limites do efeito de real produzido no texto e pelo texto, que se reduz a descobrir pontos de semelhança com a realidade, tem enorme dificuldade com eles: não cabem totalmente na moldura simbólica que lhes é dada, vazando, escorrendo, pingando". Ver em: PERCINO, Eziel Belaparte. Murilo Rubião: a bárbara porcelana. Dissertação (Teoria Literária e Literatura Comparada), Universidade de São Paulo, São Paulo, 2012, pg. 90. Disponível em: http://www.teses.usp.br/teses/disponiveis/8/8151/tde-08012013-122559/pt-br.php. Último acesso: 19/06/2018.
} 
histórias e dos primeiros heróis. Até certo ponto, alguns contornos dos mitos cristãos despontam desse universo, retomando a promessa de renovação e de reestabelecimento da mensagem original. Manifesta-se, assim, uma voz profética em cada narrativa de Rubião, que seduz seus ouvintes a buscar a repetição do velho e a alegoria dos antigos arquétipos.

No entanto, a orfandade e o desarraigamento atávicos aos personagens murilianos logo contradizem e calam essa voz. Nada parece mais contrário à cosmologia bíblica do que a inconsequência de tais vidas. Como afirma José Paulo Paes, não há intervenção divina no mundo erguido por Rubião ${ }^{272}$, assim como não há punição possível para os construtores de um edifício que sequer consegue ser concluído - seu castigo jaz na própria obrigação de levantálo. A profecia bíblica revela-se, portanto, de tal maneira desfigurada e irreconhecível que se transforma no avesso de sua mensagem. Daí surge, mais uma vez, o riso tão amargo produzido por essas histórias. O conto muriliano, a partir da tentativa hiperbólica de reconstrução de um mundo cujo significado já está preso a um passado absoluto inacessível, ou seja, ao passado do universo épico por excelência ${ }^{273}$, torna-se, ironicamente, um mundo sem passado algum. Das velhas histórias, não resta senão uma encenação farsesca e paródica, cujo destino mais apropriado é o picadeiro.

O segundo resultado da consciência simbólica descrita por Barthes, mais próxima à obra de Rubião, é contradita pela própria ausência, ou ao menos pela reclusão, do conteúdo que deseja ser signo. Com efeito, esse núcleo anterior às metamorfoses, anterior à conotação por imagens, mantém-se escondido de todos, inclusive do agente de tais transformações. Conforme aquilo que apresentamos no terceiro capítulo e no começo deste ${ }^{274}$, a tentativa mais óbvia de sobreposição do signo ao conteúdo vem com as figuras animais. Carregados de uma capacidade profunda em simbolizar e significar as experiências humanas, servindo como espelho quase cristalino das suas intenções e das suas pretensões, os animais sempre estiveram a serviço da fabulação humana, seja para apontar seus vícios, seja para louvar suas virtudes. Por ser o totem

\footnotetext{
272 Ver nota de rodapé 86.

273 Sobre o passado absoluto do mundo épico, sua fundamentação lendária e sua abrangência coletiva, influenciamo-nos pelos conceitos de Bakhtin sobre o assunto: “O passado épico, separado das épocas posteriores por uma fronteira impenetrável, se mantém e se desvela somente na forma de uma lenda nacional. A epopeia apoiase unicamente nesta lenda. Não se trata de saber se esta é a fonte efetiva da epopeia - o importante é que o suporte da lenda é imanente à própria forma da epopeia, do mesmo modo que lhe é imanente o passado absoluto. O discurso épico é enunciado sob a forma de lenda. O mundo épico do passado absoluto, por sua própria natureza, é inacessível à experiência individual e não admite pontos de vista e apreciações pessoais. Não se pode vê-lo, senti-lo, tocá-lo, não pode ser considerado sob nenhum ponto de vista, não se pode experimentá-lo, analisá-lo, mostrá-lo ou penetrar nas suas entranhas. Ele é dado somente enquanto lenda, sagrada e peremptória, que envolve uma apreciação universal e exige uma atitude de reverência para consigo". Ver em: BAKHTIN, Mikhail. Epos e romance - sobre a metodologia do estudo do romance. In: Questões de literatura e de estética - a teoria do romance. Trad. BERNARDINI, Aurora Fornoni et alii. São Paulo: Editora Hucitec, 1988, pg. 408.

${ }^{274}$ Ver nota de rodapé 251.
} 
das manifestações mais primitivas da humanidade, coube ao animal, por sua posição ao mesmo tempo tão distante e tão próxima do ser humano, a primazia de emprestar-lhe suas características e também de passar por processos de antropomorfização.

Vimos, contudo, que a presença animal em Murilo Rubião costuma trazer consigo a marca do inacabamento, de algo transitório e falho. Essa figuração manca obedece, retomando a citação de Barthes, às segundas considerações do crítico sobre a consciência simbólica, em seu nível mais negativo - o de uma analogia que, embora se pretenda justa, deixa o excedente de um "determinismo mal liquidado"275 entre as duas partes. Isto é, as duas instâncias da consciência simbólica nunca conseguem preencher com exatidão e de maneira autossuficiente a distância que há entre elas, malgrado a relação de semelhança entre o signo e o seu conteúdo.

A insuficiência se acentua conforme os animais cedem espaço a figuras cada vez mais distantes do homem. Entre Teleco e suas duas formas mais memoráveis - o coelho e o canguru - há, no mínimo, de um ao outro animal, o afastamento que metaforiza suas próprias mudanças de humor. Assim como no caminho metamórfico de Alfredo, que culmina na introspecção do dromedário, testemunhamos a radicalidade de seu isolamento social. Ou seja, o leitor ainda está diante de um discurso que fala do homem a partir de sua própria racionalidade e expressividade, mesmo que escondidas sob o corpo de um bicho. Em grande parte dos contos, contudo, as metamorfoses se recusam à familiaridade animal. Até mesmo em Teleco e Alfredo, que priorizam esse tipo de metamorfose, há transformações que contrariam qualquer expectativa por transparência e por forças simbólicas.

$\mathrm{Na}$ medida em que o abismo entre as novas formas dos personagens e as características humanas aumenta, acentua-se o estranhamento produzido por essas metamorfoses. Quando não há sequer a mediação familiar da figura animal, o desconforto do efeito insólito também se intensifica.

Os bebês autômatos de Aglaia são um exemplo dessa impressão, uma vez que trazem consigo a silhueta e até mesmo o comportamento humanos, mas apresentam assustadores olhos de vidro. Frios como uma máquina e congêneres do homem, seu surgimento na narrativa dá início a um jogo de afastamento absoluto frente à condição humana. Esses efeitos, por sua vez, dão origem à inquietação do duplo ${ }^{276}$. O estranhamento causado por essa presença que também é ausência, familiar e igualmente desconhecida, está, de maneira ainda mais radical, ligado àquilo que Barthes diz sobre o deslize de significação do símbolo. A inexatidão dessas novas metamorfoses, cujo descolamento entre conteúdo e forma se mostra de maneira drástica, já

\footnotetext{
275 Ver citação de Barthes, nota de rodapé 270.

${ }^{276}$ Ver nota de rodapé 145 sobre o Unheimliche.
} 
indica o começo da cisão entre símbolo e metáfora. Elas anunciam, com precisão, o extravio necessário para conduzir aquilo que repousa sobre o campo da familiaridade - ou seja, dos símbolos -, para caminhos cada vez mais desconcertantes.

Sobre a diferença entre os dois pontos dessa trilha e sobre o espaço que há entre eles, Paul Ricœur afirma que o símbolo "funciona como um 'excesso de significação"”. Ou seja, pelo seu caráter aglutinador, ele, ainda segundo o filósofo, "assimila mais do que apreende uma semelhança. Além disso, ao assemelhar algumas coisas com outras, assemelha-nos com aquilo que assim é significado"277. Portanto, esse poder de assimilação do símbolo, de combinação dentro de si de imagens e de valores diversos, a partir de suas semelhanças, é o responsável por lhe dar sua espessura ao mesmo tempo expressiva e opaca, rica e fugidia, pois "aquilo que nos símbolos pede para vir à linguagem, mas que nunca ingressa totalmente na linguagem, é sempre algo de poderoso, eficaz e forte" ${ }^{278}$. Vem daí, também, a sua diferença primordial para a metáfora, uma vez que "a última é invenção livre do discurso, o primeiro [o símbolo] está vinculado ao cosmos. [...] No universo sagrado, a capacidade de falar funda-se na capacidade que o cosmos tem de significar, por conseguinte, a lógica do sentido deriva da estrutura real do universo sagrado" 279 .

Há, dessa forma, na obra de Murilo Rubião, uma metáfora que se quer símbolo e que deseja a profundidade de um solo sagrado. Mas seus movimentos impõem tantos estranhamentos, deslocamentos e redundâncias de sentido que as metamorfoses, em vez de se verticalizarem, continuam na horizontalidade do rés-do-chão. Ao fim dessa busca por uma experiência simbolizada e simbolizante, a metamorfose não alcança senão a condição de metáfora de uma demanda infrutífera, pois impossível.

Assim, as metamorfoses do conto muriliano perdem o ponto de apoio que costumavam guiá-las nas narrativas anteriores ${ }^{280}$, em que um mundo de semelhanças lhes garantia o conforto das associações. Elas já não carregam consigo, também, o traço do extraordinário capaz de contestar a racionalidade do homem civilizado, como aquelas que espantavam os heróis da literatura fantástica do século XIX. Além disso, não há um recobrimento exato entre a camada metamórfica lançada sobre o mundo ficcional de Murilo Rubião e acontecimentos que possam estar escondidos sob ela, como num relato alegórico e didático. Mesmo nos contos aparentemente mais alegóricos, como no caso de $O$ edifício, cujo enredo parece ser uma

\footnotetext{
277 RICCEUR, Paul. Teoria da interpretação - o discurso e o excesso de significação. Trad. MORÃO, Artur. Lisboa: Edições 70, 1976, pp. 67-68.

${ }^{278}$ Idem, ibidem. pg. 75.

${ }^{279}$ Idem, ibidem. pg. 73.

${ }^{280}$ Como aquelas analisadas na introdução deste estudo.
} 
retomada do mito da Torre de Babel, há um deslize de sentido e de intenção entre a história lendária e o conto que não permite a simples leitura alegórica. Afinal, como a história de um edifício inútil e inacabável pode se justapor, sem excessos ou sem mínguas, à lenda de uma torre destruída por simbolizar as ambições de toda a humanidade?

De resto, sobra à metamorfose ser o tema de seu próprio rebaixamento. Entre o artifício que ornamenta e que se acrescenta ao discurso e à potência simbólica que o transcende, as metamorfoses em Murilo Rubião se comportam como metáforas da sua própria busca por uma dessas direções e da sua consequente queda. Elas já não são mais capazes nem de explicar e de aproximar os objetos do mundo, nem de adorná-los e aperfeiçoá-los. Desligadas de um passado e tão esvaziadas quanto os homens e mulheres desse universo, as metamorfoses metaforizam a sua própria condição. Ou melhor, elas abrem mão de sua capacidade de metaforizar o outro para se transformarem em seu próprio objeto. Assim, enfraquecidas suas funções simbolizadoras ou ornamentais, elas restam no mundo como a ideia e a imagem de si mesmas, uma vez que o núcleo catalizador de suas ações nunca se revela - e talvez nem mesmo exista.

Vistas sob os mais diversos ângulos no jogo de espelhos do conto muriliano, as metamorfoses abandonam sua posição de mero reflexo para tornarem-se sujeito de seus próprios atos. Se aquilo que está diante do espelho nunca aparece, quem nos garante que seu reflexo seja menos ou mais real do que ele? Como metáfora de sua própria condição e de sua própria demanda, as metamorfoses se substantivam e, mais do que isso, se elevam, ironicamente, à estatura de quase personagem dentro dos contos de Murilo Rubião ${ }^{281}$. No fim das contas, num universo congelado onde os homens já perderam sua qualidade de agentes do próprio destino, as metamorfoses surgem como uma das únicas alternativas de ação e de movimento à narrativa. A metáfora, portanto, já não está acima, abaixo ou ao redor do mundo: ela é o próprio mundo. Ela corre latente e viva por entre nós, embora isso leve ao efeito contrário no conto de Rubião, como veremos adiante.

Ortega y Gasset, ao comentar os procedimentos artísticos de seu tempo, aponta, justamente, o advento da metáfora voltada ao revés como um dos aspectos mais característicos e mais vigorosos desse novo fazer artístico. Dessa maneira, elimina-se a ilusão de que a metáfora está em outro lugar além da realidade para apresentá-la, observá-la e representá-la como mais um componente do mundo e das coisas:

\footnotetext{
${ }^{281}$ Seria demasiado afirmá-las como um personagem dentro da obra muriliana. Com efeito, as metamorfoses não possuem uma unidade que lhes assegure os contornos característicos para tal papel. Elas, por sua diversidade e por sua inconstância, estão fora de qualquer ordem taxionômica, de tipos ou até mesmo de complexidade definidoras dos personagens ficcionais. Cabe-nos, portanto, enxergá-las como uma força motriz, estimuladora dos movimentos e das ações da intriga tal que, devido à sua potência, convergem para si os demais elementos da narrativa.
} 
Ao se substantivar a metáfora, se faz, mais ou menos, protagonista dos destinos poéticos. Isto implica simplesmente que a intenção artística mudou de signo, que se voltou ao revés. Antes se vertia a metáfora sobre uma realidade, à maneira de adorno, renda ou capa de chuva. Agora, ao revés, procura-se eliminar o sustentáculo extrapoético ou real e se trata de realizar a metáfora, fazer dela a res poética. Porém essa inversão do processo estético não é exclusiva do mister metafórico, mas sim se verifica em todas as ordens e com todos os meios até transformar-se num caráter geral - como tendência - de toda a arte do momento. ${ }^{282}$

Isso, obviamente, são linhas bastante gerais que, inclusive, não se aplicam somente à literatura. No entanto, há um movimento parecido na obra de Murilo Rubião. Com efeito, a metamorfose de nosso autor parece descer de seu status transcendental e simbólico ou puramente retórico para se transformar naquilo que realmente é, assim como "o quadro, renunciando a emular a realidade, se transformaria no que autenticamente é: um quadro - uma irrealidade" ${ }^{283}$. Ou seja, nesse jogo de substantivação da metamorfose, ela explicitaria seu próprio caráter de irrealidade, de mera representação e, por conseguinte, passaria a viver nos limites de sua condição constrangida à ficcionalidade. Assumida como ficção, pura e simples, a metamorfose prescinde de qualquer obrigação de responder a uma segunda exigência, seja transcendental, seja retórica. Ela pode agir e desdobrar-se livremente pelos caminhos da narrativa.

Há, porém, uma revolta escamoteada nessa aparente libertação da metamorfose no conto de Rubião. Livre das assimilações e dos adornos, ela, contudo, não parece satisfeita com sua nova condição, tampouco os personagens que dela são agentes ou vítimas. Há, como já apontamos, uma força constante que se dirige para além dos limites ficcionais, que deseja expressar e significar mais do que as fronteiras da narrativa lhe impõem. A rebeldia constante da metamorfose, consequência negativa do processo de esvaziamento da sua importância, contrasta com o otimismo de Ortega y Gasset ao afirmar a liberdade artística atual. Quando afirma que as ideias são a única coisa que se pode representar a partir da obra de arte, o crítico chega a afirmar que "tomá-las como realidade é idealizar - falsificar ingenuamente"284, e conclui dizendo que "fazê-las viver em sua irrealidade mesma é, digamos assim, realizar o irreal enquanto irreal. Aqui não vamos da mente ao mundo, mas, ao revés, damos plasticidade, objetivamos, mundificamos os esquemas, o interior e subjetivo"285.

Insatisfeitas, contudo, com sua nova condição, as metamorfoses são as manifestações da revolta contra esse mundo fechado, cujas saídas parecem trancadas. Vimos acima que

\footnotetext{
${ }^{282}$ ORTEGA Y GASSET, José. A desumanização da arte. Trad. ARAÚJO, Ricardo. São Paulo: Cortez, 1991, pg. 63.

${ }^{283}$ Idem, Ibidem. pg. 65

${ }^{284}$ Idem, ibidem. pg. 64.

${ }^{285}$ Idem, ibidem. pp. 64-65. Grifo do autor.
} 
qualquer ambição por novidade é severamente punida dentro da ficção muriliana. A busca por uma mudança intangível se debate contra os limites estreitos de um universo sufocante. Congeladas no tempo e no espaço, nem mesmo as metamorfoses, metáforas vivas da transformação do mundo, conseguem resolver a incógnita da configuração unidimensional do conto de Rubião. Caem na multiplicação estéril, embora continuem a se movimentar.

\section{Experiência estilhaçada}

Dentro de um mundo que, à primeira vista, está tão emparedado e onde qualquer tentativa de emancipação leva à ruína de seus habitantes, há certos acontecimentos inusitados que abrem frestas nesses muros, apesar de seu tempo e de seu tamanho diminutos. Eles surgem como pequenas fissuras nesse bloco sólido que dá consistência à obra de Murilo Rubião, revelando por vezes nuances inesperadas para um mundo tão uniforme. Uma delas já foi citada neste mesmo capitulo: a pequena estrela que Bárbara pede a seu marido e que, possivelmente, representa seu último desejo. Após agir com um apetite destrutivo e avassalador, capaz de devorar, mesmo que metaforicamente, objetos cujas dimensões físicas e, sobretudo, simbólicas extrapolam as medidas do bom-senso humano, a heroína pantagruélica de Rubião se contenta, em seu desfecho, com a menor estrela presente no céu.

A quebra das expectativas operada pelo desfecho de Bárbara vem com o alívio do fim aparente de uma condenação sem culpa. Tanto o narrador como sua esposa pareciam trilhar o mesmo caminho de Teleco, do marido de Aglaia, do vizinho do homem do boné cinzento e de tantas outras figuras do rol de personagens murilianos. Em outras palavras, ambos pareciam se encaminhar inevitável e irresistivelmente à destruição. Ou, talvez, abraçariam uma opção ainda mais drástica e aceitariam a violência de seus castigos, dando continuidade, assim como Sísifo, às dores de suas penitências ${ }^{286}$. Na melhor das hipóteses, eles tomariam o rumo de uma existência estoica que talvez os salvasse fisicamente, tal qual Alfredo e o ex-mágico, mas que não pouparia seus espíritos e violaria sua integridade.

\footnotetext{
${ }^{286}$ Vimos, como possível retomada do mito de Sísifo em Murilo Rubião, o conto $O$ edifício, no qual a construção de um arranha-céus segue adiante sem nunca chegar à sua conclusão. Mas há outros. No conto Petúnia, por exemplo, o protagonista Éolo aceita reproduzir tarefas bastante insólitas e se contenta em repeti-las pelo resto de sua vida - arrancar do solo as flores que brotavam do corpo enterrado de sua esposa, desenterrar o corpo de suas filhas que, embora estejam mortas, voltam à vida quando saem da terra e retocar o retrato de sua mãe, cujas tintas sempre se desfazem. Assim passa seus dias e assim, também, termina a narração de sua vida, perspicaz ao ligar períodos enumerativos para realçar o caráter cíclico do futuro de Éolo: "Não dorme. Sabe que os seus dias serão consumidos em desenterrar as filhas, retocar o quadro, arrancar as flores. Traz o rosto constantemente alagado pelo suor, o corpo dolorido, os olhos vermelhos, queimando. O sono é quase invencível, mas prossegue". Ver em: RUBIÃO, Murilo. Petúnia. In: Murilo Rubião - obra completa. Op. cit. pg. 189.
} 
A minúscula estrela, porém, contrariando a certeza do marido de que o próximo pedido seria a lua, carrega a potência de subverter todo o conto. Ela desponta como o cessar-fogo de uma situação violenta e intolerável que levaria uma família à ruína. Além disso, ela também surge como a única esperança de solução para a trama da história que, como sabemos, costuma ficar em aberto no universo de Rubião ou, o que é pior, não se contenta senão com o aniquilamento de seus personagens. Há muito poder dentro dessa minúscula estrela. Há nela a perspectiva de mudança de três vidas, há também o apaziguamento de uma realidade intolerável que se aquiesce, que se arrefece. Em resumo, existe esperança em seu surgimento. A oportunidade de transformação do mundo que dela aflora metamorfoseia a intriga do conto e a própria aridez da escrita muriliana, tão rígida na construção de suas imagens e na elaboração de seu discurso. Nessa estrela há, portanto, uma promessa de experiência, uma promessa de vida possível, mesmo que tudo isso seja fugaz, breve e limitado como o seu próprio brilho.

Poderíamos usar, como contra-argumento, a contínua passividade do protagonista que mais uma vez se submete aos caprichos de sua esposa. Entretanto, dessa vez parece haver, de fato, algo novo na dinâmica do casal. Como nos esclarece o narrador, o "derradeiro pedido" de Bárbara vem acompanhado de um respiro "aliviado" por parte daquele e por uma mudança no rosto desta, cujo semblante nunca parecera "tão grave" ao seu companheiro ${ }^{287}$. Com efeito, há uma ruptura radical em relação às expectativas geradas pelo conto. Surge, pela primeira e única vez, a possibilidade de escapar a um destino que lhes fazia frente de maneira inexorável.

Não obstante, existem desfechos de outros contos que, assim como na história de Bárbara, ensaiam uma espécie de tumulto no bloco muriliano. Alguns deles, inclusive, já foram abordados e analisados ao longo deste estudo. Em Bruma (a estrela vermelha), vimos como o protagonista se enleva por uma visão arrebatadora ao encontrar, enfim, a estrela de cuja autenticidade ele duvidara e que fora o motivo pelo qual ele perdeu Dora e seu irmão. Também vimos, em Marina, a intangível, os versos resultantes do cortejo ruidoso e caótico da santa/musa do poeta/jornalista. Ainda mais esperançosa, otimista e poética é a conclusão do pirotécnico morto-vivo, cuja experiência metafísica de cores vibrantes e metamórficas um dia será compartilhada por toda humanidade, numa alvorada branca que tomará o mundo e que aliviará os seus anseios: “Amanhã o dia poderá nascer claro, o sol brilhando como nunca brilhou. Nessa hora os homens compreenderão que, mesmo à margem da vida, ainda vivo, porque a minha existência se transmudou em cores e o branco já se aproxima da terra para exclusiva ternura dos meus olhos" ${ }^{288}$. 
Há ainda outros exemplos de contos que estremecem o universo sitiado de Rubião ${ }^{289}$. O que eles têm em comum, além da quebra de expectativas, é a capacidade de fuga poética de um mundo aparentemente sem saídas. Todos eles, cada um à sua maneira, emprestam ao conjunto da obra muriliana um tom lírico que contradiz as suas linhas gerais. Sérgio Milliet, um dos primeiros críticos que o escritor teve, já havia notado isso ${ }^{290}$. Ele percebeu o potencial poético da obra de Rubião, quando o resto da crítica ainda se limitava às comparações com outros escritores e à busca por uma definição genérica de sua produção. Embora não concordemos com toda a sua afirmação ${ }^{291}$, o crítico acerta ao apontar os momentos de fuga, de devaneio, de reviravolta poética encontrados no conto do autor. São momentos, ainda segundo Milliet, cuja fluidez e cujo ritmo da prosa se aproximam da poesia e criam uma ruptura em seu tecido.

Neles, há um apaziguamento da metamorfose revoltada, que só se movimentava a partir de sua ambição pela totalidade e por uma forma derradeira. Longe de buscar o aniquilamento do mundo para concluir sua busca, ela se contenta, de repente, com o fugidio, com o breve, com o fragmentado. É o momento em que a gigante metamórfica se satisfaz com uma estrelinha, em que o cético adolescente abraça a realidade (também uma estrela) de seu irmão, em que o poeta ávido pelos versos definitivos se resigna ao criar um poema de sons estúpidos e pétalas rasgadas. Em suma, há em breves instantes, em certos contos de Rubião, um momento de rendição positiva e de aparição de algo quase inominável, como se sua dinâmica perversa se transviasse por um segundo e esbarrasse numa realidade inefável que devesse ser sufocada, mas cuja força é capaz de fissurar os muros e romper com o silêncio.

Além disso, são nessas passagens em que o acontecimento sobrenatural esvaziado consegue escapar da corrosão irônica de seu narrador, habituado a destruir seus monumentos mágicos antes mesmo de eles fincarem a base no chão. Assim como a ironia cede seu lugar, as construções hiperbólicas descompassam e perdem força, abrindo espaço para uma única e derradeira imagem que, em toda a sua fragilidade de flores e estrelas, aparenta conter todo o significado do mundo. Duas figuras minúsculas, mas grandiosamente simbólicas e ornamentais,

\footnotetext{
${ }^{289}$ Como é o caso do conto A Casa do Girassol Vermelho. Nele, um grupo de adolescentes desfruta da liberdade conquistada após a morte do patriarca Simeão, que tiranizava e violentava suas vidas. Como fruto da vitória e estopim do recomeço, uma das moças, Belinha, vê nascer um girassol de seu ventre, prodígio narrado nas últimas linhas do conto: "Esticou para o alto os olhos inexpressivos e embaçados. Abaixou-os depois para o ventre, onde começavam a surgir as primeiras pétalas de um minúsculo girassol vermelho". Ver em: . A Casa do Girassol Vermelho. In: Murilo Rubião - obra completa. Op. cit. pg. 97.

${ }^{290}$ Ver nota de rodapé 7.

${ }^{291}$ Sérgio Milliet aproxima a obra de Rubião ao poema em prosa, o que pensamos ser demasiado. Embora existam momentos de muito lirismo na obra do autor, ela não se aproxima desse gênero em seus requisitos básicos: a unidade, a brevidade e a gratuidade. Sobre a importância dessas três características para o gênero do poema em prosa, ver: BERNARD, Suzanne. Le poème en prose : de Baudelaire jusqu'à nos jours. Paris : Librairie A. - G. Nizet, 1994.
} 
capazes de verticalizar uma realidade que nos parece tão horizontal e uniforme. Capazes, também, de romper um mecanismo aparentemente indestrutível. Apesar de suas imagens tão gastas e tão triviais, elas são as únicas imagens que conseguem se manter de pé no solo arenoso da ficção muriliana.

Dois mundos inteiros dentro de imagens tão efêmeras. Tão efêmeras que, embora radicalizem o universo muriliano, são logo esquecidas diante da impressão geral causada por feras, monstros e gigantes grotescos. Mas elas continuam lá, guardando o segredo de um desfecho possível para uma experiência cada vez mais estilhaçada. 


\section{Referências}

\section{Epígrafes}

BLANCHOT, Maurice. O espaço literário. Trad. CABRAL, Álvaro. Rio de Janeiro: Rocco, 1987;

HOFFMANN, E. T. A. Os autômatos. In: Contos fantásticos. Trad. CAVALCANTI, Claudia. Rio de Janeiro: Imago Editora, 1993;

MENDES, Murilo. Poliedro. São Paulo: Companhia das Letras, 2010;

PAZ, Octavio. Signos em rotação. Trad. LEITE, Sebastião Uchoa. 3. ed. São Paulo: Editora Perspectiva, 1996;

PIRANDELLO, Luigi. Seis personagens à procura de autor. Trad. FLAKSMAN, Sérgio. São Paulo: Peixoto Neto, 2004.

\section{Obra de Murilo Rubião}

RUBIÃO, Murilo. A Casa do Girassol Vermelho e outros contos. São Paulo: Companhia das Letras, 2006;

. O pirotécnico Zacarias e outros contos. São Paulo: Companhia das Letras, 2006;

. O homem do boné cinzento e outros contos. São Paulo: Companhia das Letras, 2007; . Murilo Rubião: obra completa. São Paulo: Companhia das Letras, 2010;

\section{Crítica sobre Murilo Rubião}

ANDRADE, Vera Lúcia, MIRANDA, Wander Melo. As visões do invisível. In: Jornal Estado de Minas. Murilo Rubião, o ex-mágico aos 70 anos. Belo Horizonte, 31 de maio de 1986. Disponível em: http://www.murilorubiao.com.br. Último acesso: 19/06/2018; 
ARRIGUCCI JR, Davi. Minas, assombros e anedotas (os contos fantásticos de Murilo Rubião), In: Enigma e comentário - ensaios sobre literatura e experiência. São Paulo: Companhia das Letras, 1987;

. O seqüestro da surpresa, In: Outros achados e perdidos. São Paulo: Companhia das Letras, 1999;

O mágico desencantado ou as metamorfoses de Murilo. Suplemento, Belo Horizonte, n. ju 2016, p. 13-15, 2016;

BARBOSA, Manuela Ribeiro. K no Brasil: Kafka, Murilo Rubião e Aníbal Machado. Tese (Teoria da Literatura e Literatura Comparada), Universidade Federal de Minas Gerais, Belo Horizonte, 2014, pg. 130. Disponível em: http://www.bibliotecadigital.ufmg.br/. Último acesso: 19/06/2018;

BASTOS, Alcmeno. Murilo Rubião e a questão da causalidade. In: GARCÍA, Flavio, BATALHA, Maria Cristina (org.). In: Murilo Rubião: 20 anos depois de sua morte. Rio de Janeiro: EdUERJ, 2013;

BASTOS, Hermenegildo José. Aglomerações: o espaço do fantástico muriliano. In: Cerrados: revista do curso de pós-graduação em literatura, Brasília, v. 11, p. 9-6, 2001;

Literatura e colonialismo - Rotas de navegação e comércio no fantástico de Murilo Rubião. Brasília: Editora Universidade de Brasília; Plano Editora: Oficina Editorial do Instituto de Letras-UnB, 2001;

BASTOS, Hermenegildo. Do insólito ao espectral em "Ofélia, meu cachimbo e o mar". In: GARCÍA, Flavio, BATALHA, Maria Cristina (org.). Murilo Rubião: 20 anos depois de sua morte. Rio de Janeiro: EdUERJ, 2013;

CABRAL, Cleber Araújo. Lugares de Bruma: coordenadas do imaginário narrativo de Murilo Rubião. Dissertação (Teoria da Literatura e Literatura Comparada), Universidade Federal de Minas Gerais, Belo Horizonte, 2011, pg. 99. Disponível em: http://www.bibliotecadigital.ufmg.br/. Último acesso: 19/06/2018;

CAMPOS, Paulo Mendes. Um conto em 26 anos. In: Os bares morrem numa quarta-feira: crônicas. São Paulo: Ática, 1980; 
CANDIDO, Antonio. A nova narrativa. In: A educação pela noite. 6. ed. Rio de Janeiro: Ouro sobre Azul, 2011;

CARNEIRO, Flávio. Escrever é escrever de novo: a escrita infinita em Murilo Rubião. In: In: GARCÍA, Flavio, BATALHA, Maria Cristina (org.). Murilo Rubião: 20 anos depois de sua morte. Rio de Janeiro: EdUERJ, 2013;

COELHO, Nelly Novaes. Os dragões e.... In: Estado de São Paulo. Suplemento Literário. São Paulo, 06 de agosto de 1996. Disponível em: http://www.murilorubiao.com.br. Último acesso: 19/06/2018;

EULÁLIO, Alexandre. Animais de estimação. In: O Globo. Matéria e Memória, Rio de Janeiro, 23 de agosto de 1965, pg. 3. Disponível em: http://www.murilorubiao.com.br. Último acesso: 19/06/2018;

GARCÍA, Flavio. Aspectos dos discursos fantásticos contemporâneos, pegados “às unhas”, em um conto "não pronto para a publicação" de Murilo Rubião. In: GARCÍA, Flavio, BATALHA, Maria Cristina (org.). Murilo Rubião: 20 anos depois de sua morte. Rio de Janeiro: EdUERJ, 2013;

GOULART, Audemaro Taranto. Modernidade e melancolia na obra de Murilo Rubião. In: MARQUES, Reinaldo e SOUZA, Eneida Maria de (org.). Modernidades e alternativas na América Latina. Belo Horizonte: Editora UFMG, 2009;

IANNACE, Ricardo. Murilo Rubião e as arquiteturas do fantástico. São Paulo: Editora da Universidade de São Paulo/Fapesp, 2016;

JARDIM, Rachel. Realidade, fantasia. In: $O$ Globo. Rio de Janeiro. 22 de outubro de 1978. Disponível em: http://www.murilorubiao.com.br. Último acesso: 19/06/2018;

LUCAS, Fábio. A arte do conto de Murilo Rubião. Estado de São Paulo. São Paulo, 21 de agosto de 1983. Disponível em: www.murilorubiao.com.br. Último acesso: 19/06/2018;

MILLIET, Sérgio. O Ex-Mágico. In: Estado de São Paulo, 3 - XII - 47. Disponível em: http://www.murilorubiao.com.br. Último acesso: 19/06/2018;

MOURÃO, Rui. O pirotécnico Zacarias. In: Revista Colóquio. Lisboa, no 25, maio de 1975. Disponível em: http://www.murilorubiao.com.br. Último acesso: 19/06/2018; 
MORAES, Marco Antônio de (Org.). Mário e o pirotécnico aprendiz (Cartas de Mário de Andrade e Murilo Rubião). Belo Horizonte: Ed. UFMG; São Paulo: IEB-USP; São Paulo: Ed. Giordano, 1995;

NUNES, Sandra Regina Chaves. Visões da crítica. Disponível em: http://www.murilorubiao.com.br. Último acesso: 19/06/2018;

PAES, José Paulo. Um sequestro do divino. In: A aventura literária: ensaios sobre ficção e ficções. São Paulo: Companhia das Letras, 1990;

PERCINO, Eziel Belaparte. Murilo Rubião: a bárbara porcelana. Dissertação (Teoria Literária e Literatura Comparada), Universidade de São Paulo, São Paulo, 2012. Disponível em: http://www.teses.usp.br/teses/disponiveis/8/8151/tde-08012013-122559/pt-br.php. Último acesso: 19/06/2018;

RESENDE, Otto Lara. Adesão ao herói de nosso tempo. In: CABRAL, Cleber Araújo (org.). Mares interiores: correspondência de Murilo Rubião \& Otto Lara Resende. Belo Horizonte: Autêntica Editora/Editora UFMG, 2016;

RUBIÃO, Murilo. Depoimento e vida. In: CABRAL, Cleber Araújo (org.). Mares interiores: correspondência de Murilo Rubião \& Otto Lara Resende. Belo Horizonte: Autêntica Editora/Editora UFMG, 2016;

SCHWARTZ, Jorge. Murilo Rubião: a poética do Uroboro. São Paulo: Ática, 1971; Murilo Rubião: um clássico do conto fantástico. In: RUBIÃO, Murilo. O pirotécnico Zacarias e outros contos. São Paulo: Companhia das Letras, 2007;

WERNECK, Humberto. Prefácio: A aventura solitária de um grande artista. In: RUBIÃO, Murilo. O homem do boné cinzento e outros contos. São Paulo: Companhia das Letras, 2007;

ZAGURY, Eliane. Murilo Rubião, o contista do absurdo. In: A palavra e os ecos. Petrópolis: Editora Vozes, 1971. 


\section{Referências gerais}

ADORNO, Theodor W. Apuntes sobre Kafka. In: Prismas - la crítica de la cultura y la sociedad. Traducción: SACRISTÁN, Manuel. Barcelona: Ediciones Ariel, 1962;

ALAZRAKI, Jaime. ¿Qué es lo neofantástico? In: Mester (UCLA). Los Angeles, Vol. XIX, nº 2, 1990;

ANDERS, Günther. Kafka: pró e contra - os autos do processo. Tradução de Modesto Carone. São Paulo: Perspectiva, 1993;

BACHELARD, Gaston. Lautréamont. Trad. ALMEIDA, Fábio Ferreira. Goiânia: Edições Ricochete, 2013;

BAKHTIN, Mikhail. Questões de literatura e de estética - a teoria do romance. Trad. BERNARDINI, Aurora Fornoni et alii. São Paulo: Editora Hucitec, 1988;

- A cultura popular na Idade Média e no Renascimento: o contexto de François Rabelais. Trad. VIEIRA, Yara Frateschi. 6. ed. São Paulo: Hucitec; Brasília: Editora Universidade de Brasília, 2008;

BARTHES, Roland. L'ancienne, rhétorique/aide-mémoire. Recherches rhétoriques. In: Communications. Paris: Seuil, 11, 1968;

O efeito do real. In: O rumor da língua. Trad: LARANJEIRA, Mario. São Paulo: Martins Fontes. 2004;

Crítica e verdade. Trad. PERRONE-MOISÉS, Leyla. 3. ed. São Paulo: Perspectiva, 2009;

BATAILLE, Georges. Métamorphose. In: CEuvres complètes - tome I. Paris: Gallimard, 1970;

BENJAMIN, Walter. Magia e técnica, arte e politica: ensaios sobre literatura e história da cultura - Obras escolhidas vol. 1. Tradução: ROUANET, Sergio Paulo. São Paulo: Brasiliense, 1994;

BERGSON, Henri. O riso: ensaio sobre a significação da comicidade. Trad. BENEDETTI, Ivone Castilho. São Paulo: Martins Fontes, 2004; 
BERNARD, Suzanne. Le poème en prose : de Baudelaire jusqu'à nos jours. Paris: Librairie A. - G. Nizet, 1994;

BETTELHEIM, Bruno. A psicanálise dos contos de fada. Trad. CAETANO, Arlete. 7. ed. São Paulo: Editora Paz e Terra, 1996;

BORGES, Jorge Luis. Fiç̧ões. Trad. ARRIGUCCI JR, Davi. São Paulo: Companhia das Letras, 2007 ;

Prólogo. In: CASARES, Adolfo Bioy. A invenção de Morel. Trad. MOLINA, Sérgio. 4. ed. São Paulo: Biblioteca Azul, 2016;

BORNHEIM, Gerd. Temas de filosofia. São Paulo: Editora da Universidade de São Paulo, 2015;

BRAVO, Álvaro Fernandez. Desenjaular o animal humano. Trad. MACIEL, Maria Esther. In: MACIEL, Maria Esther (org.). Pensar/escrever o animal: ensaios de zoopoética e biopolítica. Florianópolis: Editora da UFSC, 2011;

BRUNEL, Pierre (org.). Dicionário de mitos literários. Trad. SUSSEKIND, Carlos et alii. Rio de Janeiro: José Olympio, 1997;

CALVINO, Italo. Por que ler os clássicos. Trad. MOULIN, Nilson. São Paulo: Companhia das Letras, 2007;

(org.). Contos fantásticos do século XIX - O fantástico visionário e o fantástico cotidiano. Trad. DIAS, Maurício Santana, São Paulo: Companhia das Letras, 2011;

CAMUS, Albert. $O$ mito de Sísifo. Trad. ROITMAN, Ari e WATCH, Paulina. 5. ed. Rio de Janeiro: Record, 2008;

CANDIDO, Antonio. $O$ discurso e a cidade. Rio de Janeiro: Academia Brasileira de Letras, 2010;

CARONE, Modesto. A metamorfose. In: Franz Kafka: essencial. São Paulo: Penguin Classics Companhia das Letras, 2011;

CARPENTIER, Alejo. A literatura do maravilhoso. Trad. GOLDONI, Rubia Prates e MOLINA, Sérgio. São Paulo: Editora Revista dos Tribunais, Edições Vértice, 1987; 
CAVALIERE, Arlete. A magia das máscaras. In: GÓGOL, Nicolai. O nariz \& A terrível vingança. Trad. CAVALIERE, Arlete. São Paulo: Edusp, 1990;

CESERANI, Remo. O Fantástico. Trad. TRIPADALLI, Nilton Cezar. Curitiba: Editora UFPR, Londrina: EDUEL, 2006;

CHEVALIER, Jean, GHEERBRANT, Alain, com a colaboração de: BARBAULT, André et alii. Dicionário de símbolos: mitos, sonhos, costumes, gestos, formas, figuras, cores, números. Trad. COSTA E SILVA, Vera da, et alii. Rio de Janeiros: José Olympio, 2008;

CHIAMPI, Irlemar. O realismo maravilhoso: forma e ideologia no romance hispanoamericano. 2. ed. São Paulo, Perspectiva, 2008;

CHKLOVSKI, Viktor. A arte como procedimento. In: Teoria da literatura: formalistas russos. Trad. FILIPOUSKI, Ana Maria et alii. Porto Alegre: Editora Globo, 1973;

CORTÁZAR, Julio. Bestiário. Trad. FILHO, Remy Gorga. Rio de Janeiro: Nova Fronteira, 1986;

. Valise de cronópio. Trad. ARRIGUCCI JR, Davi e BARBOSA, João Alexandre. 2. ed. São Paulo: Editora Perspectiva, 1993;

DELEUZE, Gilles, GUATTARI, Félix. Kafka: para uma literatura menor. Trad. GODINHO, Rafael. Lisboa: Assírio \& Alvim, 2003;

DERRIDA, Jacques. Margens da filosofia. Trad. COSTA, Joaquim Torres e MAGALHÃES, António M. Campinas: Papirus, 1991;

. O animal que logo sou (a seguir). Trad. LANDA, Fábio. São Paulo: Editora UNESP, 2002 ;

DEZOTTI, Maria Celeste Consolin. A tradição da fábula: de Esopo a La Fontaine. Brasília: Editora Universidade de Brasília, São Paulo: Imprensa Oficial do Estado de São Paulo, 2003;

DUBOIS, Jacques et alii. Retórica geral. Trad. MOISÉS, Carlos Felipe et alii. São Paulo: Cultrix/Edusp, 1970;

ECO, Umberto. Seis passeios pelos bosques da ficção. Trad. FEIST, Hildegard. São Paulo: Companhia das Letras, 2017; 
FONTANIER, Pierre. Les figures du discours. Paris : Flammarion, 1968;

FOUCAULT, Michel. As palavras e as coisas. Trad. MUCHAIL, Salma Tannus. 4. ed. São Paulo: Martins Fontes, 1987;

FREUD, Sigmund. O “estranho”. In: Obras psicológicas completas de Sigmund Freud; Volume XVII (1917-1919). Trad. SOUZA, Eudoro Augusto Macieira de. Rio de Janeiro: Imago Editora, 1976 ;

FRIEDMAN, Norman. O ponto de vista na ficção: o desenvolvimento de um conceito crítico. Trad: MELO, Fábio Fonseca de. Revista USP. São Paulo, nº 53, pp. 175-177, março/maio 2002; FURTADO, Filipe. A construção do fantástico na narrativa. Lisboa: Livros Horizonte, 1980; GINZBURG, Carlo. Olhos de madeira: nove reflexões sobre a distância. Trad. BRANDÃO, Eduardo. São Paulo: Companhia das Letras, 2001;

GREEMBERG, Clement. Modernist painting. Forum Lectures, 1960. Disponível em: http://www.sharecom.ca/greenberg/modernism.html. Último acesso: 19/06/2018;

GUIMARÃES, Hélio. Introdução: Um romance em abismo. In: ASSIS, Machado de. Esaú e Jacó. São Paulo: Penguin Classics Companhia das Letras, 2012;

JOLLES, André. O chiste. In: Formas simples. Trad. CABRAL, Alvaro. São Paulo: Editora Cultrix, 1976;

KAFKA, Franz. O processo. Trad. CARONE, Modesto. São Paulo: Companhia das Letras, 2000;

. O castelo. Trad. CARONE, Modesto. São Paulo: Companhia das Letras, 2006;

A metamorfose. In: CARONE, Modesto (org. e trad.). Franz Kafka: essencial. São Paulo: Penguin Classics Companhia das Letras, 2011;

KAYSER, Wolfgang. O grotesco: configuração na pintura e na literatura. Trad. GUINSBURG, Jacó. São Paulo: Editora Perspectiva, 1986;

KRISTEVA, Julia. Pouvoirs de l'horreur : essai sur l'abjection. Paris: Éditions du Seuil, 1986;

KRYSINSKI, Wladimir. Dialéticas da transgressão. Trad. NEIS, Ignacio Antonio; PETERSON, Michel e CANKO, Ricardo Iuri. São Paulo: Perspectiva, 2007; 
KUNDERA, Milan. A arte do romance. Tradução: FONSECA, Teresa Bulhões Carvalho da. São Paulo: Companhia das Letras, 2009;

JAROUCHE, Mamede Mustafa. Uma poética em ruínas. In: Livro das mil e uma noites: volume I: ramo sírio. Trad. JAROUCHE, Mamede Mustafa. 4. ed. São Paulo: Biblioteca Azul, 2017;

JORGE, Eduardo. Lobisomem, sem ameaças. In: MACIEL, Maria Esther (org.). In: Pensar/escrever o animal: ensaios de zoopoética e biopolítica. Florianópolis: Editora da UFSC, 2011;

LAUTRÉAMONT, Conde de. Os cantos de Maldoror: poesia, cartas, obra completa. Trad. WILLER, Claudio. 2. ed. São Paulo: Iluminuras, 2015;

LESTEL, Dominique. A animalidade, o humano e as "comunidades híbridas". Trad. FUX, Jacques e MACIEL, Maria Esther. In: MACIEL, Maria Esther (org.). Pensar/escrever o animal: ensaios de zoopoética e biopolítica. Florianópolis: Editora da UFSC, 2011;

LINS, Osman. Lima Barreto e o espaço romanesco. São Paulo: Ática, 1976;

LUKÁCS, Georg. Ensaios sobre literatura. Trad. KONDER, Giseh Vianna. Rio de Janeiro: Civilização Brasileira, 1965;

MACIEL, Maria Esther. Narrativas da animalidade. In: Literatura e animalidade. Rio de Janeiro: Civilização Brasileira, 2016;

MARCHESE, Angelo, FORRADELLAS, Joaquín. Hipérbole. In: Diccionario de retórica, crítica y terminología literaria. Barcelo: Editorial Ariel, 1994;

MORAES, Eliane Robert. O corpo impossível. São Paulo: Editora Iluminuras, 2010;

NETO, João Angelo Oliva. Mínima gramática das Metamorfoses de Ovídio. In: OVÍDIO. Metamorfoses. Trad. DIAS, Domingos Lucas. São Paulo: Editora 34, 2017;

NUNES, Benedito. O animal e o primitivo: os Outros de nossa cultura. Apresentação de Jaime Larry Benchimol. História, Ciências, Saúde - Manguinhos, Rio de Janeiro, v.14, suplemento, pg. 282, dez. 2007;

ORTEGA Y GASSET, José. A desumanização da arte. Trad. ARAÚJO, Ricardo. São Paulo: Cortez, 1991; 
PLATÃO. O banquete. In: Diálogos. Trad. SOUZA, José Cavalcante; PALEIKAT, Jorge; COSTA, João Cruz. São Paulo: Abril Cultural, 1983;

POE, Edgard Allan. Histórias extraordinárias. Trad. PAES, José Paulo. 2. ed. São Paulo: Editora Cultrix, 1958;

A filosofia da composição. In: Poemas e ensaios. Trad. MENDES, Oscar e AMADO, Milton. 3. ed. São Paulo: Globo, 1999;

PROPP, Vladimir. Morfologia do conto maravilhoso. Rio de Janeiro: Forense - Universitária, 1984;

RANCIÈRE, Jacques. Politicas da escrita. Trad. RAMALHETE, Raquel; RIBEIRO, Eloisa Araújo; VASSALO, Ligia e VILANOVA, Laís Eleonora. São Paulo: Editora 34, 2017;

RICEUR, Paul. Teoria da interpretação - o discurso e o excesso de significação. Trad. MORÃO, Artur. Lisboa: Edições 70, 1976;

ROAS, David. A ameaça do fantástico: aproximações teóricas. Trad. FUKS, Julián. São Paulo: Editora Unesp, 2014;

ROSENFELD, Anatol. Texto/contexto I. 5. ed. São Paulo: Editora Perspectiva, 1996;

SARTRE, Jean-Paul. Animadab, ou o fantástico considerado como uma linguagem. In: Situações I-crítica literária. Trad. PRADO, Cristina. São Paulo: Cosac Naify. 2005;

SCHWARZ, Roberto. Uma barata é uma barata é uma barata. In: A sereia e o desconfiado. Rio de Janeiro: Paz e Terra, 1981;

SELIGMANN-SILVA, Márcio. Mal-estar na cultura: corpo e animalidade em Kafka, Freud e Coetzee. In: MACIEL, Maria Esther (org.). Pensar/escrever o animal: ensaios de zoopoética e biopolitica. Florianópolis: Editora da UFSC, 2011;

SONTAG, Susan. A vontade radical: estilos. Trad. MARTINS FILHO, João Roberto. São Paulo: Companhia das Letras, 2015;

TODOROV, Tzvetan. As estruturas narrativas. Tradução de Leyla Perrone-Moisés. 4. ed. São Paulo: Perspectiva, 2006; 
Introdução à literatura fantástica. Trad. CASTELLO, Maria Clara Correa. 3. ed. São Paulo: Perspectiva. 2008;

TOLSTOI, Leão. Kolstomer. In: Obra completa - volume III. Trad. AMADO, Milton e MENDES, Oscar. Rio de Janeiro: Editora Nova Aguilar, 1993;

VAX, Louis. La séduction de l'étrange. Paris: Quadrige/PUF, 1987;

WATT, Ian. A ascensão do romance. Trad. FEIST, Hildegard. São Paulo: Companhia das Letras, 2010;

WILLER, Claudio. Prefácio: O astro negro. In: LAUTRÉAMONT, Conde de. Os cantos de Maldoror: poesia, cartas, obra completa. Trad. WILLER, Claudio. 2. ed. São Paulo: Iluminuras, 2015. 